

\section{DISCLAIMER}

This report was prepared as an account of work sponsored by an agency of the United States Government. Neither the United States Government nor any agency Thereof, nor any of their employees, makes any warranty, express or implied, or assumes any legal liability or responsibility for the accuracy, completeness, or usefulness of any information, apparatus, product, or process disclosed, or represents that its use would not infringe privately owned rights. Reference herein to any specific commercial product, process, or service by trade name, trademark, manufacturer, or otherwise does not necessarily constitute or imply its endorsement, recommendation, or favoring by the United States Government or any agency thereof. The views and opinions of authors expressed herein do not necessarily state or reflect those of the United States Government or any agency thereof. 


\section{DISCLAIMER}

Portions of this document may be illegible in electronic image products. Images are produced from the best available original document. 


\section{DISCLAIMER}

"This book was prepared as an account of work sponsored by an agency of the United States Government. Neither the United States Government nor any agency thereof, nor any of their employees, makes any warranty, express or implied, or assumes any legal liability or responsibility for the accuracy, completeness, or usefulness of any information, apparatus, product, or process disclosed, or represents that its use would not infringe privately owned rights. Reference herein to any specific commercial product, process, or service by trade name, trademark, manufacturer, or otherwise, does not necessarily constitute or imply its endorsement, recommendation, or favoring by the United States Government or any agency thereof. The views and opinions of authors expressed herein do not necessarily state or reflect those of the United States Government or any agency thereof."

This report has been reproduced directly from the best available copy.

Available from the National Technical Information Service, U. S. Department of Commerce, Springfield, Virginia 22161.

Price: Printed Copy A10

Microfiche A01 
DOE/ET/27232-T5

Distribution Category UC-66g.

\title{
UTILIZATION OF GEOTHERMAL ENERGY IN THE MINING AND PROCESSING OF TUNGSTEN ORE \\ FINAL REPORT
}

\author{
Prepared By \\ M.V. Erickson \\ S.B. Lacy \\ G.D. Lowe \\ A.M. Nussbaum \\ K.M. Walter \\ C.A. Willens
}

WESTEC Services, Inc.

3211 Fifth Avenue

San Diego, California 92103

Prepared For:

The Department of Energy

Division of Geothermal Energy

Under DOE Contract 03-79-ET-27232 


\section{TABLE OF CONTENTS}

Section

Title

Page

1

INTRODUCTION

1

1.1

Statement of Objectives

1

1.1 .1

Overall Objectives

1

1.1 .2

Specific Objectives

1

1.2

Conclusions and Recommendations

2

Background: Union Carbide Corporation - Metals

Division, Bishop, California Operations

General

Ammonium Paratungstate Process 3

1.4

Energy Utilization Survey

\section{5}

Introduction

Present Energy Consumption $\quad 5$

1.4.2.1

Electrical Consumption

$\mathbf{5}$

Steam Consumption

5

Geothermal Applications at the Pine Creek Tungsten

Complex

Introduction

End Uses 10

1.5.2

1.5 .2 .1

Boiler Water Preheat

10

1.5 .2 .2

Space Heating

10

Current Heat Exchangers

10

1.5.2.3

Current Heat Exchangers

2

GENERAL ENGINEERING EVALUATION

2.1

Introduction

13

2.2

Weather Analysis 
$\underline{\text { Section }}$

\subsection{1}

2.2.2

2.3

2.4

2.4 .1

2.4 .2

2.4.3

2.4.4

2.4.4.1

2.4.4.2

2.4.4.3

2.4.4.4

3

3.1

3.2

3.2 .1

3.2 .2

3.2.3

3.2 .4

3.2 .4 .1

3.2.4.2

3.3

3.3.1
Title

$\underline{\text { Page }}$

Introduction

Adjustment for Elevation Change

13

14

Geothermal Fluid Production/Reinjection

14

Geothermal Heat Extraction

17

17

Piping System

18

18

18

Pipe Materials

21

Insulation

22

Conduit

23

Heat Exchanger Materials

25

DESIGN OF GEOTHERMAL ENERGY SYSTEM

Introduction

25

Mechanical Equipment

25

25

General

25

Submersible Pump

27

Heat Exchangers

27

Existing System

Mine and Mill Change Rooms

Geothermal Energy Applications

29 
ECONOMICS

Introduction

Economic Incentives

Introduction

Tax Incentives 
Section

\subsection{2}

5.2.3

5.3

5.3.1

5.3.2

5.3.3

5.4

5.4.1

5.4.2

5.4 .3

5.4.4

5.4.5

5.4.6

5.4.7

5.4.8

5.4.9

5.5

5.5.1

5.5.2

5.5.3

5.5.4
TABLE OF CONTENTS (Continued)

Title

Page

Geophysical Measurements in the Vicinity of the Pine Creek Mine

Springs and Wells in Relation to Geology 56

Hydrogeochemistry 59

Field and Laboratory Analysis 59

Quality of Groundwater 63

Groundwater of Round Valley and Pine Creek Canyon 67

Geochemical Prediction of Aquifer Temperature 67

Introduction

67

Cation Geothermometers

70

Cation Geothermometers: $\mathrm{Na} / \mathrm{K} / \mathrm{Ca}$

70

Explanation of Cation Geothermometer Results

Silica as a Basis for Estimating Aquifer

Temperature

73

Silica Temperatures

74

Silica Mixing Models

79

Hydrogen and Oxygen Isotopes: Stable Isotopes

80

Unstable Isotopes

84

Model of the Pine Creek Mine Low-Temperature Geothermal Resource

Summary of Data on the Easy Going Warm Spring

Heat Generation and Loss

Geothermal Regime of the Pine Creek Mine

Conclusion

89 
$\underline{\text { Section }}$

6

6.1

6.2

6.3

6.3.1

6.3.2

6.3.3

6.4

6.4.1

6.4.1.1

6.4.1.2

6.4.1.3

6.4.1.4

6.4.1.5

6.4.1.6

6.4.1.7

6.4.1.8

6.4.1.9

6.4.1.10

6.4.1.11

6.4.1.12

6.5

TABLE OF CONTENTS (Continued)

\section{Title}

INSTITUTIONAL BARRIERS ASSESSMENT

Introduction

Jurisdictional Overlap

Ownership of the Resource

Surface and Mineral Rights

Water Rights

Surface Rights in the Area Surrounding the Mill

Permits Required for Geothermal Exploration at the Existing Mill Site

96

California Division of Oil and Gas

97

Drilling Requirements

Environmental Requirements

The Regional Water Quality Control Board

The Air Pollution Control District.

The Geothermal Ordinance of Inyo County

Definitions Under the Ordinance

Unlawful Acts

Permits

Conditions

Standards

100

Planning Standards

100

Drilling Standards

100

102 


\section{$\underline{\text { Section }}$}

7.1

7.1.1

7.1 .2

7.1.3

7.2

7.2.1

7.2.1.1

7.2.1.2

7.2.1.3

7.2 .2

7.2.2.1

7.2.2.2

7.2.2.3

7.2.3

7.2.3.1

7.2:3.2

7.2.3.3

7.2 .4

7.2.4.1

7.2.4.2

7.2.4.3

7.2.5

TABLE OF CONTENTS (Continued)

Title

ENVIRONMENTAL FACTORS

Preliminary Assessment of Environmental Data Base

Literature Search

Field Investigation

Interviews

Environmental Assessment

Water Quality

Environmental Setting

Potential Impacts/Constraints

Mitigation/Alterna tives

Biological Resources

Environmental Setting

Potential Impacts/Constraints

Mitigation/Alternatives

Noise

e

Environmental Setting

Potential Impacts/Constraints

Mitigation/Alternatives

Geological Resources

Environmental Setting

Potential Impacts/Constraints

Mitigation/Alternatives

Climatology and Air Quality
Page

105

105

105

106

106

106

106

106

111

111

111

111

112

113

113

113

113

114

114

114

114

116

116 
TABLE OF CONTENTS (Continued)

$\underline{\text { Section }}$

Title

Page

7.2.5.1

Environmental Setting

116

7.2.5.2

Impacts/Constraints

125

Mitigation/Alternatives

127

Visual Quality/Aesthetics

127

7.2.6.1

Environmental Setting

127

7.2.6.2

Potential Impacts/Constraints

128

7.2.6.3

Mitigation/Alternatives

128

7.2.7

Land Use Compatibility

129

7.2.7.1

Environmental Setting

129

7.2.7.2

Potential Impacts/Constraints

134

7.2.7.3

Mitigation/Alternatives

134

7.2 .8

Archaeological Resources

134

7.2.8.1

Environmental Setting

134

7.2.8.2

Potential Impacts/Constraints

135

7.2.8.3

Mitigation/Alternatives

135

7.3

Known Data Sources Not Yet Reviewed

136

7.4

Conclusion

136

8

ALTERNATE GEOTHERMAL ENERGY SOURCE

141

8.1

Introduction

141

8.2

Transportation from Mono-Long Valley

141

8.3

Site Selection

143

8.4

Long Distance Hot Water Transport

143

8.5

Engineering Evaluation of Long Distance Transport

148 
Section

TABLE OF CONTENTS (Continued)

8.5.1

8.5.2

8.6

8.7

8.7.1

8.7 .2

8.7.2.1

8.7.2.2

8.7.2.3

8.7 .3

8.7 .4

8.7.4.1

8.7.4.2

8.7.4.3

8.7 .5

8.8

8.8.1

8.8.1.1

8:8.1.2

8.8.2

8.8.2.1
Title

Page

Heat Loss

148

Economics of Transport

149

Preliminary Justification for Drillsite Location

149

Institutional Barriers Assessment

154

Introduction

154

Obtaining Rights to Geothermal Resources on Land Administered by the U.S. Forest Service

154

Prospecting Permit

154

Geothermal Leasing

155

An Evaluation of Union Carbide's Potential for Obtaining a Federal Geothermal Lease

158

Obtaining Rights to Geothermal Resources on Land Which is Privately Owned

158

Obtaining a Right-of-Way for the Geothermal Brine Transportation Pipeline

159

U.S. 395

159

Inyo County Paved Secondary Road

159

An Alternate Pipeline Corridor

160

Summary and Conclusions

160

Environmental Factors

161

Climatology and Air Quality

161

Study Area Characteristics

161

Constraints to Development

163

Geological Resources

164

Study Area Characteristics 
TABLE OF CONTENTS (Continued)

Section

8.8.2.2

8.8.3

8.8.3.1

8.8.3.2

8.8.3.3

8.8.4

8.8.4.1

8.8.4.2

8.8 .5

8.8.5.1

8.8.5.2

8.8 .6

8.8.6.1

8.8.6.2

8.8.7

8.8.7.1

8.8.7.2

8.8 .8

8.9

9

9.1

9.2

9.2 .1
Title

Constraints to Development

Water Quality

Study Area Characteristics

Water Management

Constraints to Development

Biological Resources

Study Area Characteristics

Constraints to Development

Land Use Compatibility

Study Area Characteristics

Constraints to Development

Visual Quality/Aesthetics

Study Area Characteristics

Constraints to Development

Noise

174

Study Area Characteristics

174

Constraints to Development

174

Cultural Resources

174

Conclusion

ALTERNATES TO GEOTHERMAL DEVELOPMENT AT PINE CREEK

181

Introduction

181

Hydroelectric Power at Pine Creek

181

Theoretical Power

181 


\section{Section}

9.2 .2

9.3

9.3 .1

9.3 .2

9.3.3

Number

1-1

1-2

1-3

2-1

2-2

2-3

3-1

3-2

3-3

$3-4$

5-1

5-2

5-3

$5-4$

\section{TABLE OF CONTENTS (Continued)}

Title

Page

181

Expected Power

183

183

185

Mineral Production Close to Geothermal Resources

186

\section{LIST OF FIGURES}

$\underline{\text { Title }}$

Page

Schematic for the Processing of Tungsten Ore 4

Model for Mill Steam Usage $\quad 8$

Raffinate Treatment 9

Production Well With Downhole Pump 15

Injection Well

16

Energy Cascade for Geothermal System $\quad \cdot 19$

Production, Surface, Injection Facilities 26

Pine Creek Tungsten Mining Complex

Source of Geologic Data Shown on Plate 1 


\section{TABLE OF CONTENTS (Continued) LIST OF FIGURES (Continued)}

Number

Title

Page

Diagram Showing General Chemical Character of Groundwater from the Vicinity of the Pine Creek Mine

Sodium Sulfite Plume in Groundwater Downstream from the Pine Creek Mine

Measured Temperatures versus $\mathrm{Na}-\mathrm{K}-\mathrm{Ca}$ Temperature (A) and Chalcedony Temperature (B)

Variation of Dissolved-Silica Concentration With Temperature

Silica Temperatures versus Na-K-Ca Temperature

Plot of $\delta \mathrm{D}$ versus $\delta \mathrm{O}^{18}$ in Groundwater from the Vicinity of the Pine Creek Mine

Plot of Drillhole Collar Elevation versus Geothermal Gradient for Data Presented by Lachenbruch (1908), and Lachenbruch, et al. (1976)

Steady-state Limits for Crustal Temperatures, Sierra

Nevada, California (from Lachenbruch, 1968)

7-1 Location of Water Quality Monitoring Stations Near the

Pine Creek Tungsten Mine

$1979 \mathrm{SO}_{2}$ Scrubber Particulate Monthly Average

7-8 Bureau of Land Management Bishop Resource Area 
TABLE OF CONTENTS (Continued)

LIST OF FIGURES (Continued)

Number

$\underline{\text { Title }}$

Page

8-1

Alternate Site Location Mono-Long Valley KGRA

142

8-2

Unit Cost of Energy versus Load Factor

8-3

Composite Environmental Map

8-4

Hot Water Distribution Systems

Map of Long Valley Caldera Showing Coincidence of Aeromagnetic Anomalies and Modeled Average Reservoir Temperature

Study Area-Alternate Site Location

Geologic Features, Alternate Site

Theoretical Hydroelectric Power for Pine Creek

\section{LIST OF TABLES}

Number

Title

$\underline{\text { Page }}$

Union Carbide Electrical Survey Summary

Piping Materials

Properties of Geothermal Insulating Materials

Energy Consumption at Union Carbide's Tungsten Mining Complex

Energy Costs at Pine Creek (3rd Quarter 1979 Dollars)

Cash Flow Before Debt Service Conventional Fuel Forecast \#1

4-3 After Tax Analysis of Geothermal System Conventional Fuel

$$
\text { Forecast } \# 1
$$




\section{TABLE OF CONTENTS (Continued)}

\section{LIST OF TABLES (Continued)}

Number

Title

Page

After Tax Analysis of Geothermal System Conventional Fuel

Forecast \#2

46

4-7 Present Worth Analysis Conventional Fuel Forecast \#2

48

5-1 Location, Name, and Geological Relations of Springs and Wells Utilized for this Investigation

5-2 Estimated Flow Rates of Springs and Groundwater Temperature in the Vicinity of the Pine Creek Mine.

5-3 Chemical, Analysis of Water from the Vicinity of the Pine

Creek Mine as Determined During this Investigation

5-4 Groundwater Quality Analysis in the Vicinity of the Pine

Creek Mine Obtained from a Literature and Agency Search

5-5 Names, Locations and Temperatures of Numbered Springs and

Wells Shown on Figures 5-5 and 5-6

5-6 Mole Ratios of the Major and Minor Constituents in the Groundwaters from the Vicinity of the Pine Creek Mine

5-7 Measured Spring and Well Temperatures and Estimated Aquifer Temperatures Based on Chemical Geothermometers

Adjustment of Silica Values for Observed Inconsistencies

Equations Relating the Solubility of Silica as a Function of Temperature

5-10 Hydrogen- and Oxygen-Isotope Concentration of Groundwaters from the Vicinity of the Pine Creek Mine

Pine Creek Quarterly Receiving Waters

7-2 Water Quality in Pine Creek and a Local Warm Spring

The Mercalli Intensity Scale

Total Suspended Particulate Concentrations 
Number

8-1

8-2

9-1

Letter

A

B

C

TABLE OF CONTENTS (Continued)

LIST OF TABLES (Continued)

Title

Page

146

Btu/hr

Wells in Mono-Long Valley KGRA

152

186

\section{APPENDICES}

Title

Page

A-1

Heat Flux Calculations

B-1

Reservoir Confirmation Plan

Pine Creek Distribution Pipline

C-1 


\section{SECTION 1}

\section{INTRODUCTION}

\section{$1.1 \quad$ STATEMENT OF OBJECTIVES}

\subsubsection{Overall Objectives}

The overall objective of this study is to determine the engineering, economic and environmental feasibility of the utilization of low and moderate temperature geothermal heat from an area designated as valuable prospectively for geothermal resources in the mining and processing of tungsten ore at the Union Carbide - Metals Division facility near Bishop, California. A secondary objective is the development of engineering techniques in the direct use application of geothermal energy in anticipation that these techniques could be translated to other geothermal resource areas and applications.

\subsubsection{Specific Objectives}

The specific objectives of this study are as follows:

a) Prepare a preliminary geophysical evaluation of the geothermal resource within transportable range of the Union Carbide - Metals Division tungsten mining and processing complex at Pine Creek.

b) Develop a specific plan for early resource confirmation including a discussion of exploration techniques, reservoir parameters and well drilling and testing.

c) Conduct an engineering evaluation of the Pine Creek tungsten complex to identify those processes and systems which could directly utilize geothermal heat as a substitute for fossil fuel.

d) Conduct heat balance studies of the entire mill and mine to establish the technical feasibility of substituting geothermal heat for those mineral processing functions identified as compatible with the geothermal resource.

e) Determine the heat transfer methods for converting geothermal heat to process heat for those mineral processing functions identified as compatible with the geothermal resource.

f) Prepare cost estimates in terms of plant modification (capitalization) and operating costs for each alternative heat transfer approach considered to be technically feasible.

g) Determine the specific benefits of geothermal heat utilization in terms of reduced fossil fuel and electricity consumption and associated reduced energy costs. 
h) Determine feasible approaches for transporting geothermal heat to the Pine Creek tungsten complex.

i) Determine the costs of transporting geothermal heat to the Pine Creek tungsten complex based on the selected heat delivery approaches.

j) Develop a conceptual design of a geothermal energy system that could supply process steam to the Pine Creek tungsten operation and if appropriate, concurrent generation of electrical power for plant use, utilizing parameters implied by the potential resource.

k) Provide an economic analysis of such a conceptual design comparing present and future conventional fuel costs, reduced fossil fuel and electricity costs, costs of mill modifications, and comparison of other unconventional alternatives, such as low-head hydro.

1) Provide an analysis of environmental and institutional factors related to such a geothermal application.

m) Provide a final report which addresses the feasibility of utilizing geothermal energy at the Pine Creek tungsten complex. If it is determined to be technically, economically and environmentally feasible to utilize geothermal heat, provide a specific plan of pilot experiments and/or detailed engineering requirements to accomplish this objective.

\subsection{CONCLUSIONS AND RECOMMENDATIONS}

Initial economic and technical evaluation indicate that geothermal resource development at the Pine Creek mill site may not be possible. The initial geochemical analysis concludes that in order to obtain fluid within the specified temperature range for space heating, the production wells would need to be drilled to a depth of 5.7 kilometers. Drilling to this depth for low temperature fluid is considered to be a high risk, low return project and is not recommended. A specific plan for resource confirmation at the project site is presented in Appendix $B$.

Since initial geochemical analysis indicates a geothermal reservoir with significant energy potential may not exist beneath the Pine Creek tungsten complex, an alternate site for geothermal development in the Mono-Long Valley KGRA was examined. The Mono-Long Valley KGRA is approximately 30 miles from the project site and sucessful wells have been drilled in this area. Initial environmental and institutional constraints to geothermal development in the Mono-Long Valley KGRA were identified at the drilling site and along the pipeline transmission corridor to the Pine Creek tungsten complex. An initial evaluation of the technical feasibility of transporting geothermal fluid from the Mono-Long Valley KGRA is presented. Heat loss from the geothermal fluid and cost of the transmission pipeline indicate that the alternate site concept for delivering geothermal energy may not be economical. 
Although the utilization of geothermal direct heat may not be an economically viable alternative for the Pine Creek tungsten complex, this study shows that the concept of utilizing geothermal heat in moderate temperature mineral processing is in fact viable. A brief overview of potential mineral processes and milling locations that are possibly adaptable to the use of geothermal energy is presented for possible future research.

1.3 BACKGROUND: UNION CARBIDE CORPORATION - METALS DIVISION, BISHOP, CALIFORNIA OPERATIONS

\subsubsection{General}

Tungsten, one of the hardest of all metals and one of the strongest in tensile strength at high temperatures, has great industrial and national security value. Tungsten carbide is used for producing tools with extraordinary cutting ability. Tungsten is also an alloying component for steel, adding hardness. The compounds of tungsten are used in making automobile parts, fireproof cloth, pigments, $X$-ray screens, electric light bulbs, cutlery, electronic components, and dental and surgical instruments, as well as parts for lasers and military munitions.

More than a third of all tungsten ore in the United States is in California and Nevada. The largest mine, which is located near Bishop in Inyo County, California, has been operated by Union Carbide since 1937, providing the nation with its most important single source of the essential metal and the County with its largest private industry. More than 400 people (miners, skilled tradesmen, engineers, mill operators, and geologists) work at the Union Carbide Corporation's Bishop operation.

Beneath the Sierra Nevada Mountains, Union Carbide miners have excavated miles of tunnels which are connected by vertical shafts rising from the $2470 \mathrm{~m}$ to the $3540 \mathrm{~m}$ level $(8100 \mathrm{ft}$ to $11,600 \mathrm{ft})$. Ore from the mine is crushed, ground and chemically processed to a white sugar-like powder known as ammonium paratungstate. This is the main product Union Carbide ships from its Bishop operations. In addition to the principal tungsten mining, some molybdenum, an alloying metal, and copper also are mined, as well as small quantities of silver and gold.

\subsubsection{Ammonium Paratungstate Process}

Union Carbide owns patent rights to the ammonium paratungstate (APT) process (U.S. Patent Nos. 2,963,342 and 2,963,343). The APT process consists of a series of physical and chemical operations to extract tungsten from the raw ore and to produce a dry, solid product (see Figure 1-1). The raw ore from the mine is first crushed and ground to a small mesh size. The ground ore is then subjected to a series of aqueous flotations with chemical additives to remove heavy metal sulfides, resulting in a solution with a higher concentration of scheelite (tungsten bearing mineral).

The scheelite concentrate is then mixed with soda ash and water before being pressure digested in an autoclave. This operation puts the tungsten in solution so that it can be separated from the gangue (waste material) by filtration. This solution is filtered and the solids are sent to waste. 


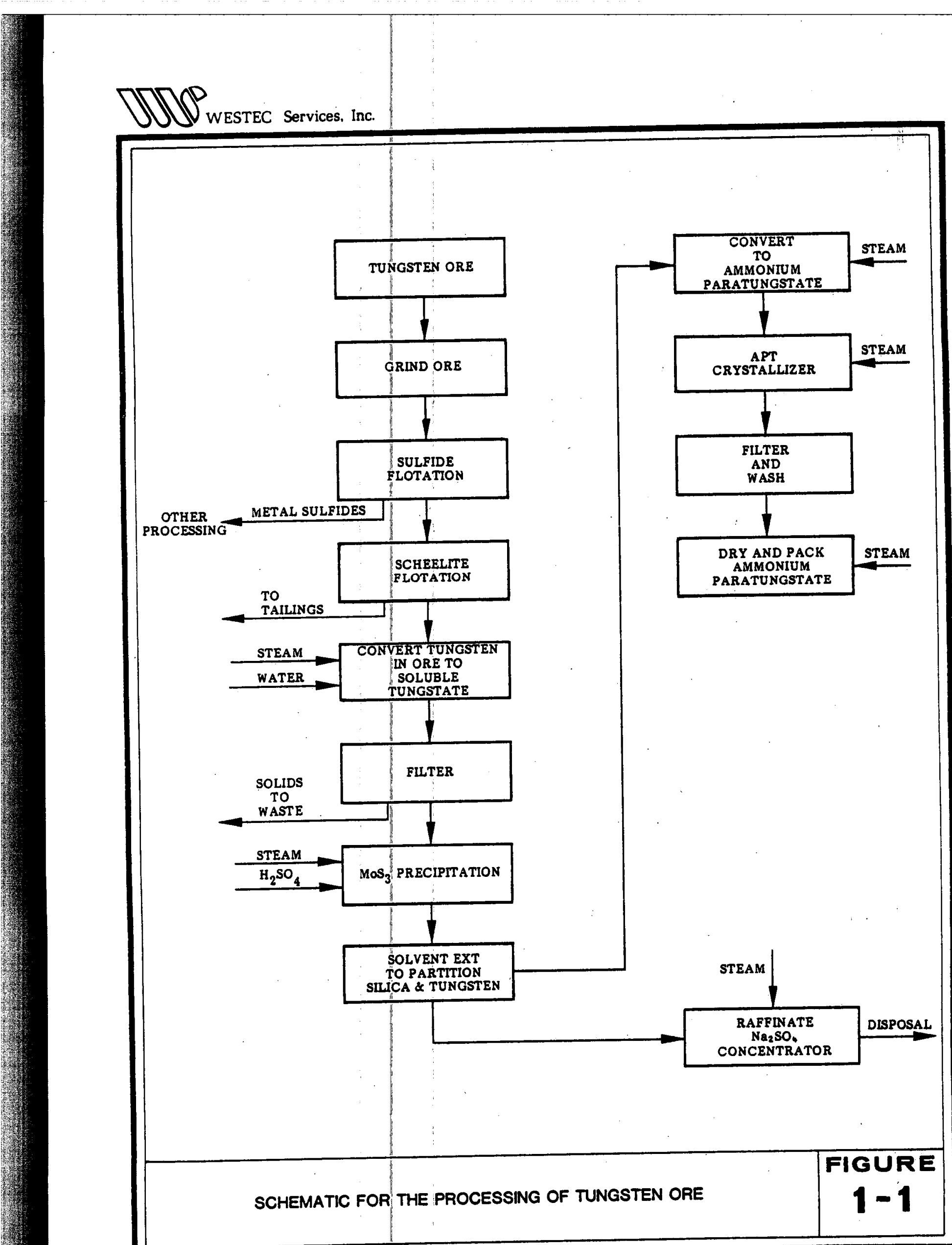


The tungsten-rich solution then goes through a series of proprietary solvent extraction operations which converts the tungsten to ammonium tungstate. This solution is processed in a crystallizer to produce solid ammonium paratungstate. The wet solids are then dried and packaged for shipment.

\subsection{ENERGY UTILIZATION SURVEY}

\subsubsection{Introduction}

A detailed engineering survey of the mill was conducted to identify which processes could potentially utilize geothermal heat as a substitute for fossil fuel generated heat. The survey concentrated on development of a model for the mill steam usage, since the primary opportunity to substitute geothermal heat for fossil fuel energy will be in the reduction of fired steam production.

\subsubsection{Present Energy Consumption}

The Pine Creek tungsten complex relies solely on purchased electricity for prime movers and fuel oil for the production of process steam. A survey was completed of current energy consumption at the Pine Creek tungsten complex to evaluate the potential for utilizing geothermal energy.

\subsubsection{Electrical Consumption}

Electricity for Union Carbide's tungsten complex is produced at a hydroelectric power generation plant approximately twenty-eight miles from Union Carbide's facilities and purchased from Southern California Edison (SCE). Power from the SCE plant is carried via a 55,000 V transmission line and is transformed onsite to $12,480 \mathrm{~V}$ for delivery.

Large pieces of rotating machinery including ball and rod mills, compressors and pumps are used in the mill for the processing of tungsten ore. An electrical use survey at the Pine Creek tungsten complex, listing major pieces of equipment and their electrical requirements, is shown in Table 1-1. Approximately 36 million kilowatt hours per year are required for the continuous operation of the mill at a cost of 3.7 cents per kilowatt hour. SCE has two rate increases pending which could result in large utility cost increases to industrial users such as Union Carbide. These rate changes would be reflected in the Energy Cost Adjustment Charges which might result in an increase of sixteen percent before 1981. This projected increase would result in electrical power costs of $\mathbf{4 . 3}$ cents per kilowatt hour for Union Carbide. The feasibility of electrical production onsite will be investigated for unconventional alternatives such as small scale hydro or geothermal electrical generation facilities to reduce purchased power requirements.

\subsubsection{Steam Consumption}

Large amounts of steam and clean water are needed for processing tungsten ore to the end product, ammonium paratungstate. The mine cuts across several water bearing fractures which results in a drainage of 442-505 liters/sec (7-8000 GPM) that collects at the lowest level of the mine. From there it is pumped to a water clarifier which supplies water for process use and the water required for process steam. 
Table 1-1

UNION CARBIDE ELECTRICAL SURVEY SUMMARY

EQUIPMENT

B\&W Boiler M.C.C. 107 Main

B\&W Boiler Fan $100 \mathrm{HP}$

Agitators, Filters, M.C.C. 108 Main

Digester M.C.C. 109 Main

Digester M.C.C. $15 \mathrm{HP}$

Boilers M.C.C. 110 Main

Boilers Water Pump $40 \mathrm{HP}$

Boilers Water Pump 60 HP

Edwards Roaster M.C.C. 111 Main

Edwards Roaster Scrubber Fan

Stripper Column Fan 75 HP

Raffinate Main

Crystallizing Circulation Pump $60 \mathrm{HP}$

Evap. Pump Dr. 75 HP

Water Reclaimer $60 \mathrm{HP}$

Slurry Agitation Dr. $\quad 60 \mathrm{HP}$

Batch Mixing M.C.C. 112 Main

30 Transfer Pumps

Agitator M.C.C. 114 Main

Agitator $40 \mathrm{HP}$

Batch Mix $40 \mathrm{HP}$

Main 3000 AMP

APT Main, 600 AMP (3 M.C.C.'s)

Crusher Area one M.C.C.

Crusher Area two M.C.C.

Crusher Area Jaw Crusher $150 \mathrm{HP}$

Crusher Area Cone Crusher 150 HP

Ball \& Rod Mill M.C.C. \#2 Main

Cyclone Feed Pump \#1

Cyclone Feed Pump \#2

Floats 20 HP (9 units)

Floats M.C.C. \#3 Main

Floats M.C.C. \#4 Main

Floats 20 HP (9 Units)

Air Blower $25 \mathrm{HP}$

M.C.C. 101 Main

Wolframite M.C.C. 102 Main

$6 \times 5$ Ball Mill $100 \mathrm{HP}$

$5 \times 6$ Ball Mill $60 \mathrm{HP}$

M.C.C. 106 Main

Air Compressor

Air Compressor 125 HP

Vacuum Pumps $30 \mathrm{HP}$ (4)

Floats 20 HP (10 units)

\begin{tabular}{rrr} 
AMPS & VOLTS \\
\cline { 2 - 3 } 70 & \\
62 & 460 \\
50 & 460 \\
29 & 465 \\
3 & 465 \\
115 & 465 \\
265 & 465 \\
55 & 465 \\
140 & 465 \\
45 & 465 \\
48.5 & 465 \\
400 & 465 \\
67 & 465 \\
50 & 465 \\
66 & 465 \\
50 & 465 \\
130 & 465 \\
38 & 465 \\
92 & 460 \\
16 & 465 \\
35 & 465 \\
1320 & 470 \\
135 & 465 \\
80 & 470 \\
100 & 470 \\
110 & 470 \\
140 & 470 \\
300 & 460 \\
140 & 460 \\
140 & 460 \\
14 & 460 \\
230 & 465 \\
210 & 440 \\
14 & 460 \\
14 & 460 \\
85 & 465 \\
270 & 465 \\
110 & 465 \\
80 & 465 \\
200 & 465 \\
110 & 470 \\
135 & 465 \\
22 & 465 \\
22 & 465
\end{tabular}

$\underline{\text { KVA } \quad \underline{K W}}$

$56 \quad 46$

$49 \quad 41$

$40 \quad 24$

$23 \quad 13$

$2.4 \quad .6$

$92 \quad 79$

$21 \quad 19$

$44 \quad 38$

$113 \quad 106$

$36 \quad 35$

$39 \quad 32$

$322 \quad 261$

$54 \quad 40$

$33 \quad 33$

$53 \quad 47$

$40 \quad 33$

$105 \quad 78$

$30 \quad 25$

$73 \quad 51$

72

$28 \quad 22$

$1075 \quad 784$

$109 \quad 71$

$65 \quad 57$

$81 \quad 73$

$88 \quad 88$

11295

$239 \quad 186$

$112 \quad 97$

$112 \quad 97$

118

$185 \quad 128$

$160 \quad 112$

11.8

119

$68 \quad 40$

$218 \quad 180$

$89 \quad 75$

$64 \quad 46$

$161 \quad 97$

$80 \quad 80$

$63 \quad 53$

$18 \quad 14$ 
Three oil fired boilers provide process steam to the Pine Creek tungsten complex. Steam consumption to the mill is supplied through a 240 psi steam header with pressure reducing stations to throttle the steam to the pressure levels required for various process stages. Seventy-two percent $(46,000 \mathrm{lb} / \mathrm{hr})$ of the produced steam is used for direct injection into the ore process stream. The steam is injected for three reasons:

- To provide the heat required to carry out the chemical reactions.

- To provide dilution of the process stream.

- Due to the corrosive nature and the fouling tendencies of the slurries being processed, direct injection is economical.

A general schematic for mill steam usage as related to the Ammonium Paratungstate (APT) process is shown in Figure 1-2.

Raffinate, a byproduct of the APT process, is treated in an energy intensive process that removes and concentrates sodium sulfate prior to disposal. The process does not require direct steam injection (see Figure 1-3) but uses nearly twenty percent of the mill's produced steam for waste treatment.

The steam usage in the Pine Creek complex was evaluated to determine whether geothermal fluid could replace fuel oil as an energy input. Because the processing of tungsten ore is highly energy intensive, a reduction in fuel oil required per pound of steam produced could result in substantial savings.

\subsection{Geothermal Applications at the Pine Creek Tungsten Complex}

\subsubsection{Introduction}

Energy is available in geothermal brine as heat. Therefore, applications for geothermal energy utilization will be analyzed in terms of economic and technical feasibility of direct or indirect heat conversion. End uses were evaluated for geothermal application based on the present source of energy use, its impact on the total energy consumption, its adaptability to using geothermal brine with available equipment, and its practicality for adapting to geothermal energy.

Process steam for the Pine Creek tungsten complex is presently supplied through a 240 psia steam header. As a large portion of this steam is directly injected into the process stream, geothermal brine cannot be used for direct applications in the ammonium paratungstate process because the predicted reservoir temperature is cooler than the required temperature for direct injection of $203 \mathrm{C}(397 \mathrm{~F})$.

The highest potential for geothermal applications will be in utilizing brine through heat exchangers to preheat water to the boilers, to provide space heating, and to heat additives prior to their introduction into the process stream. Geothermal fluid is expected to be relatively clean because of the geology of the area; therefore scaling is projected to be minimal and reinjection temperature will be limited by heat extraction efficiency instead of factors relating to solid deposition from the geothermal fluid. 


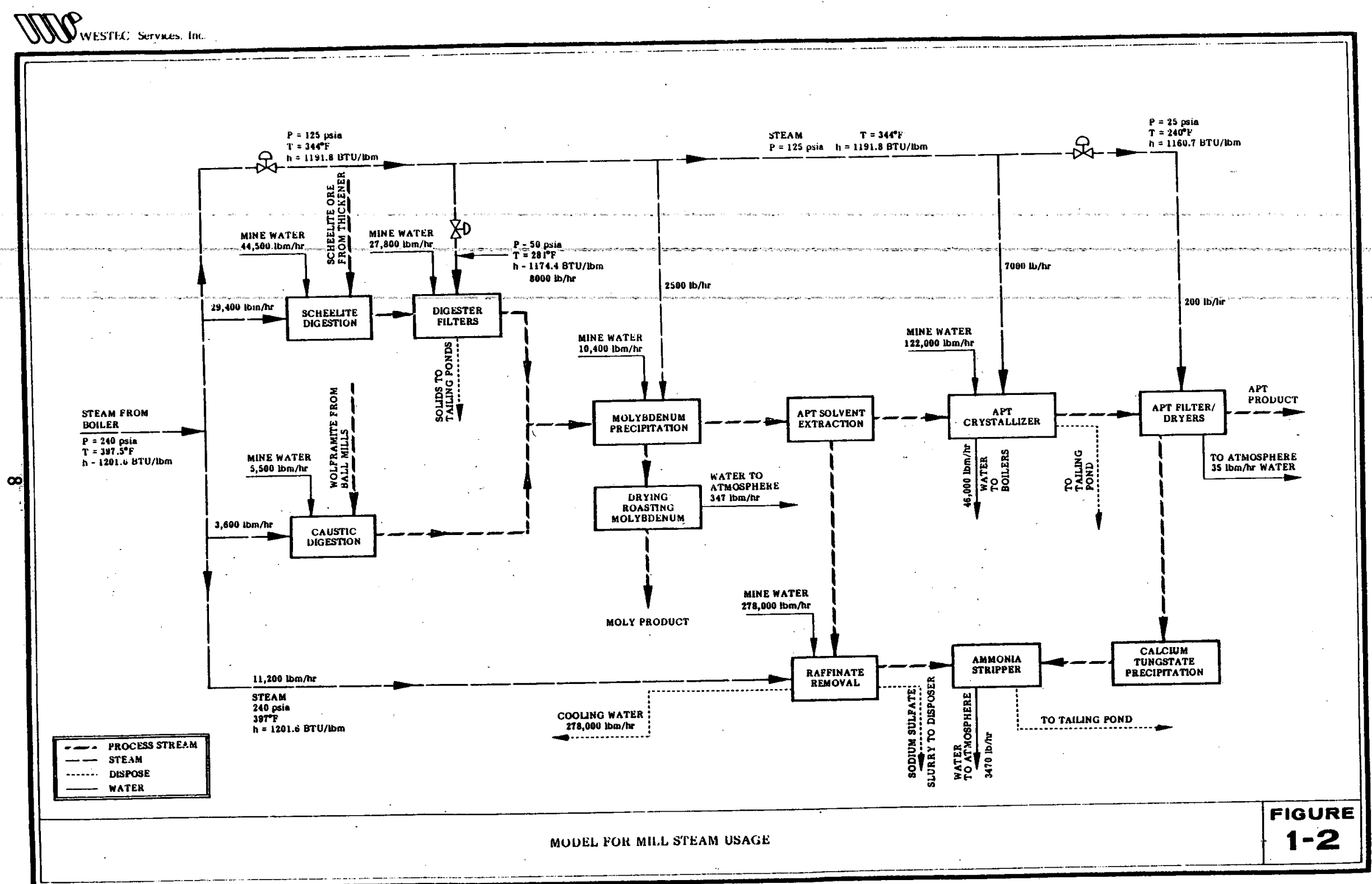


NUP WESTEC Services. Inc.

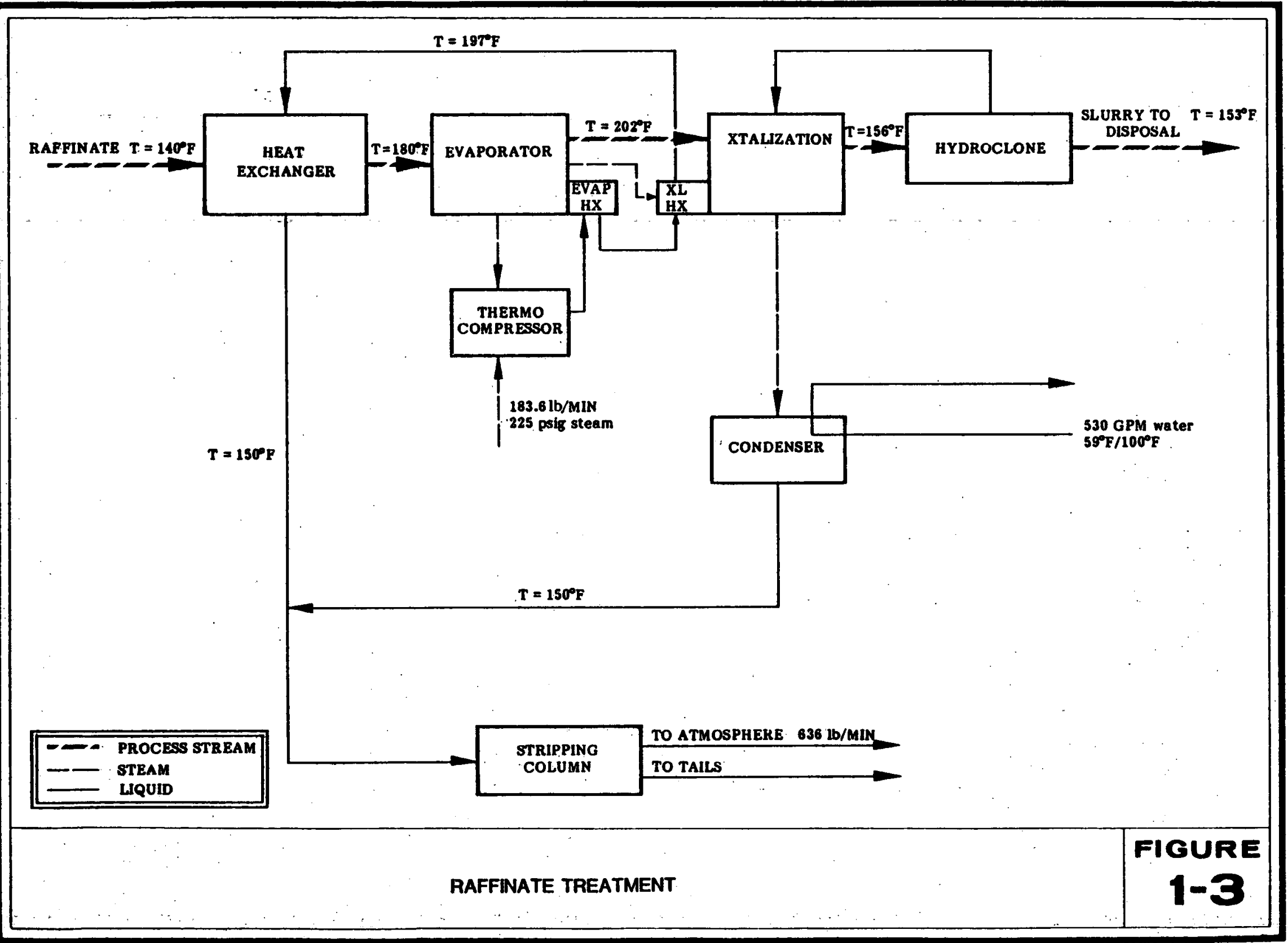


Cascading heat requirements will improve system efficiency by utilizing a large portion of the heat contained in the brine before disposal. Portions of the plant energy cycle which already use indirect heating via heat exchangers were examined for the feasibility of replacement with alternate heat exchangers using a lower temperature fluid while maintaining the same heat transfer rate.

\section{5 .2 \\ End Uses \\ 1.5.2.1 \\ Boiler Water Preheat}

Using the data supplied by Union Carbide, it was determined that a substantial decrease in fuel consumption would occur if the incoming water to the boiler feedwater pumps was preheated via geothermal fluid. If make up water from the mine at $4 \mathrm{C}(40 \mathrm{~F})$ is preheated in a counterflow heat exchanger, an inlet temperature to the boiler of $85 \mathrm{C}(185 \mathrm{~F})$ can be obtained saving $140 \mathrm{Btu} / \mathrm{lb}$ water. Currently, 72 percent $\left(5.0 \times 10^{5}\right.$ liters/day; $1.32 \times 10^{5}$ gal/day) of the water entering the boiler is preheated to $60 \mathrm{C}(140 \mathrm{~F})$ by passing through the APT crystallizer. With the remaining 28 percent $\left(2.0 \times 10^{5}\right.$ liters/day; $5.3 \times 10^{4} \mathrm{gal} /$ day) of the incoming mine water to the boiler utilizing geothermal preheat, $2.9 \times 10^{6} \mathrm{Btu} / \mathrm{hr}$ of conventional fossil fuel energy can be replaced. This is a 13 percent reduction in the amount of energy supplied by fuel oil for the make up water. The brine exit temperature can be between 82-93C (180-200F), making it possible to extract more energy for space heating or alternate uses.

\section{Space Heating}

Space heating is the most versatile use for the heat extracted from geothermal fluid. High reservoir temperatures are not required nor is the technology complicated. Geothermal water ranging from $48-114 \mathrm{C}(118-237 \mathrm{~F})$ is currently being used to heat homes and commercial establishments in Klamath Falls, Oregon, and Reykjavik, Iceland. The water is used for space heating by circulating it through very large radiators, or by transferring the heat to a closed system supplied with clean municipal water. Current space heating at the Pine Creek tungsten complex is accomplished with a fuel oil-fired furnace for the office buildings, and $4540 \mathrm{~kg} / \mathrm{hr}$ $(10,000 \mathrm{lb} / \mathrm{hr})$ of steam at $240 \mathrm{psia}$ for the mill and change room. This space heating requirement can be replaced or augmented with geothermal fluid via a different distribution system as the temperatures required for space heating are compatible with the geothermal resource.

\subsubsection{Current Heat Exchangers}

There are currently two heat exchangers at the Pine Creek tungsten complex that utilize steam to heat the process stream in the APT crystallization portion of the cycle. Each of these heat exchangers uses $1590 \mathrm{~kg} / \mathrm{hr}(3500 \mathrm{lb} / \mathrm{hr})$ of steam at $130 \mathrm{psi}$, with a heat transfer rate of $3.1 \times 10^{6} \mathrm{Btu} / \mathrm{hr}$. Heat exchangers are also used in processing raffinate, a waste byproduct of the ammonium paratungstate process, which use steam at the rate of $5080 \mathrm{~kg} / \mathrm{hr}(11,200 \mathrm{lb} / \mathrm{hr})$.

Major equipment modifications would be necessary to replace the current exchangers using geothermal heat. A larger heat exchanger or several heat exchangers 
in series will be required, but will be acceptable if the overall heat transfer rate remains constant.

Scaling is expected to be a minimal problem as initial water analysis and a geologic review of the area indicate that there will be a low percentage of dissolved solids in the geothermal fluid because of the expected reservoir temperature and the geology of the area. If the heat in the geothermal fluid is extracted prior to entry to the tungsten mill, the problems associated with geothermal heat extraction such as solid deposition can be confined to one location. 



\section{SECTION 2}

\section{GENERAL ENGINEERING EVALUATION}

\section{$2.1 \quad$ INTRODUCTION}

The energy use survey of the Pine Creek tungsten complex identified three major areas for utilizing geothermal heat to replace or augment fossil fuel energy consumption. Because of the initial reservoir evaluation, which indicated a low resource temperature, electrical generation was excluded from consideration and all uses involve direct heat applications of the geothermal fluid. The three areas considered most compatible with a low resource temperature at the tungsten complex are space heating, domestic hot water heating and preheat of the industrial water prior to entering the boiler feedwater pumps.

\subsection{WEATHER ANALYSIS}

\subsubsection{Introduction}

Climatological data has been compiled on a month-by-month basis for the town of Bishop, California (elevation $1252 \mathrm{~m}, 4108 \mathrm{ft}$ ) since 1944 . The offices and the tungsten processing mill of the Pine Creek tungsten complex are 20 miles northwest of Bishop in the Sierra Nevada Mountains at an elevation of $2380 \mathrm{~m}$ (7800 ft). Current monitoring at Pine Creek consists only of air quality analysis performed for environmental agencies; data for specific weather analysis (temperature and precipitation) are not collected.

\subsubsection{Adjustment for Elevation Change}

The weather data from Bishop has been adjusted in accordance with ASHRAE's (1977) rule for determination of heating load using climatic conditions. For interpolation of weather data, ASHRAE suggests that an approximate adjustment for higher elevations is to decrease the values of wet bulb and dry bulb temperatures by the following increments:

Dry bulb temperature: 1 degree $F$ per $200 \mathrm{ft}$

Wet bulb temperature: 1 degree $F$ per $500 \mathrm{ft}$

Bishop averages 4192 heating degree days and 1075 cooling degree days per year based on the traditional 65F (18.3C) base temperature. The annual average temperature for Bishop is 13.2C (55.9F) (U.S. Department of Commerce, 1978). Using the ASHRAE adjustments, an offset of $10.2 \mathrm{C}(18.5 \mathrm{~F})$ for the dry bulb temperature is taken for the location at Pine Creek which would result in a mean annual temperature of 3C (37.4F). This corresponds well with information obtained from personnel at the project site that stated the average annual temperature for the Pine Creek tungsten complex is $4 \mathrm{C}$.

The largest demand for space conditioning will be heating, as seen by the above weather data. The mean daily minimum dry-bulb temperature for Bishop for the 
months of December, January, February and March (the four coldest months of the year for this location) is $-4.3 \mathrm{C}(24.2 \mathrm{~F})$. This corresponds to a mean daily minimum dry-bulb temperature of $-14.6 \mathrm{C}(5,7 \mathrm{~F})$ at Pine Creek for the winter months.

\subsection{GEOTHERMAL FLUID PRODUCTION/REINJECTION}

A typical production well with a downhole submersible pump and a reinjection well required for a geothermal system are shown in Figures 2-1 and 2-2. The production well at Pine Creek would be drilled to a depth of $5700 \mathrm{~m}(1737 \mathrm{ft})$ and lined with cement casing to a depth of $2130 \mathrm{~m}(6890 \mathrm{ft})$. At this depth, the expected wellhead temperature is $121 \mathrm{C}(250 \mathrm{~F})$. To supply the geothermal energy needed to replace conventional energy sources for space heating, domestic hot water, and to preheat a portion of the boiler water, estimated at $4.5 \times 10^{10} \mathrm{Btu} / \mathrm{yr}$ or $1.52 \times 10^{7} \mathrm{Btu} / \mathrm{hr}$, a geothermal fluid flow of 30 liters per second $(450 \mathrm{gpm})$ is required. This value is based on extraction of all of the heat in the brine between the temperatures of $116 \mathrm{C}$ and $77 \mathrm{C}$ (240-170F).

This flow rate would require the use of a pump in the geothermal supply system. A downhole, totally submersible pump has been decided on for this application. Downhole pumps are currently being modified to withstand the normally corrosive environment of the geothermal brine and are being tested at East Mesa, California and Raft River, Idaho to determine endurance limits and operating procedures.

Because the Pine Creek resource has a relatively low temperature, flashing the brine to make steam for the industrial processes is not an economical process. For example, approximately 34 pounds of geothermal brine at $116 \mathrm{C}(240 \mathrm{~F})$ would be needed in a flash tank at atmospheric pressure to produce one pound of steam. This limits the heat extraction from the geothermal fluid to heating, via heat exchangers, a second fluid that is compatible with system components. For this application water will be used as the secondary fluid, which will be circulated through heating coils for space heating, enter a storage tank which will provide domestic hot water and provide feedwater for the boiler feed pumps.

After the geothermal brine passes through a series of heat exchangers, it is discharged through the reinjection line through the injection well into a compatible aquifer. A centrifugal reinjection pump will be used, if required, to pressurize the reinjection line to provide adequate flow into the reinjection well at a depth of $2450 \mathrm{~m}$ $(8000 \mathrm{ft})$.

Because of the surrounding geology, water from the geothermal reservoir is expected to be relatively clean, containing a low concentration of dissolved solids. Therefore, scaling and solid deposition on piping and process equipment should be a minimal problem. The brine reinjection temperature will be limited by the efficiency of extracting heat from the geothermal fluid in the shell and tube exchangers.

\subsection{GEOTHERMAL HEAT EXTRACTION}

The geothermal energy required to totally replace the space heating, domestic water heating and to preheat boiler feedwater is estimated at peak load to be $1.52 \mathrm{x}$ $10^{7} \mathrm{Btu} / \mathrm{yr}$, which would require approximately $450 \mathrm{gpm}$ of geothermal brine if all the 


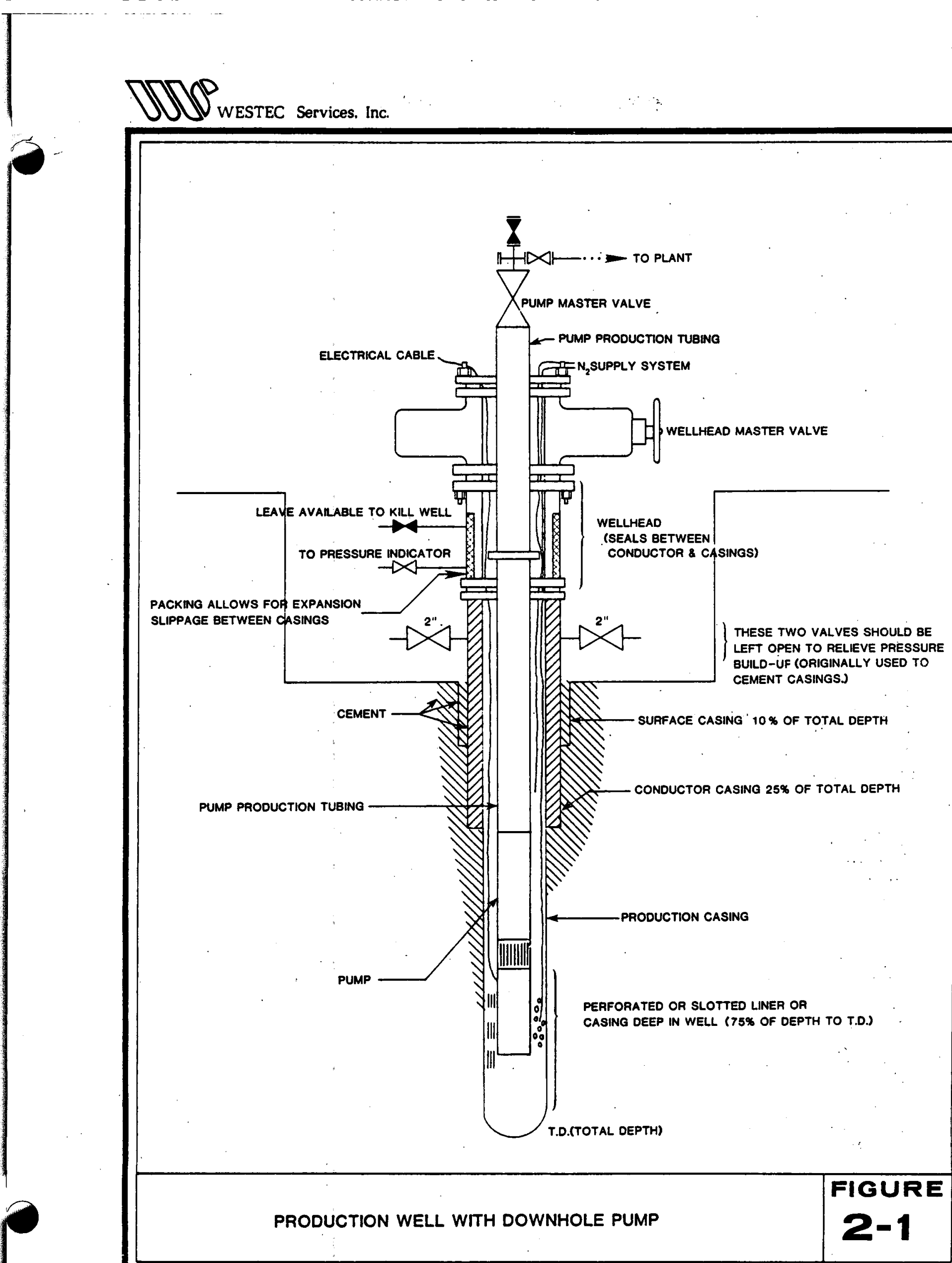

PRODUCTION WELL WITH DOWNHOLE PUMP 
heat was utilized in the geothermal fluid from $116 \mathrm{C}$ to $77 \mathrm{C}(240-17.0 \mathrm{~F})$. This heat extraction will be accomplished with shell and tube heat exchangers in a binary system with clarified mine water absorbing the heat on the shell side.

\subsubsection{Heat Delivery Methods}

There are many ways to deliver the heat contained in the geothermal brine to the point of use. The most direct method would be use of the brine itself in the areas designated as having the highest potential for end use in the Pine Creek tungsten complex. This method has the advantage of being the most efficient heat transfer method and the potential for utilizing the greatest amount of energy contained in the brine. Transporting brine throughout the distribution system has some inherent problems. Although any geothermal fluid found in the area is predicted to be low in total dissolved solids, trace elements and dissolved gases in the fluid could cause problems in the equipment due to scaling or corrosion and in the tungsten process itself due to its sensitivity to contaminants.

Because of the problems associated with direct use of the geothermal fluid, heat exchangers will be used to transfer the heat to water taken directly from the water clarifier at the tungsten mining complex. The mine cuts across several water bearing fractures which results in a drainage of $7-8000 \mathrm{gpm}$ that collects at the lowest level of the mine from where it is pumped to a water clarifier. A portion of the clarified water is used for process steam, flotation for heavy metal and scheelite separation and in other phases of tungsten ore processing. The remaining clean water is discharged into Morgan Creek.

Only minor piping changes would be required to introduce the geothermal energy system into the industrial piping at the Pine Creek tungsten complex. The normal flow of the discharge from the water clarifier to the tungsten mill will be directed through a heat exchanger for preheating industrial water to the boiler feedwater pumps.

\subsubsection{Piping System}

Heat for the Pine Creek complex is required for process applications and also for space heating and domestic hot water use. Mine runoff water heated in the boiler is for the most part consumed in the mill process, with only a relatively small amount rejected to the tailings pond. The hot water rejected from low temperature process applications could be used for space heating the office buildings and for heating the domestic supply water.

Heat for the Pine Creek complex would have to be transported from the geothermal resource to the mill area. If it is assumed that the geothermal plant is on the grounds of the mill then heat transportation would be a short distance ( $a$ few hundred yards at most).

The design for the Pine Creek mill will make use of a two-pipe hot water system. This system would entail one supply pipe of hot water for preheated boiler supply and low temperature process applications, and one return pipe of rejected water from low temperature process applications and of fice buildings use. 
Figure 2-3 is a diagram showing a schematic of the two-pipe hot water system. The geothermal brine exchanges heat with the water taken from the tungsten mine. This geothermally preheated mine water is used to provide feedwater for the existing mill boiler and also for low temperature process applications. Hot water from the low temperature processes can be cascaded to provide space heat and to heat domestic water. The heat remaining in this water would be returned to the geothermal facility to be used to preheat mine makeup water prior to entering the heat exchanger.

\subsection{3}

Storage

In large scale district distribution systems, daily demand fluctuations are a regular occurrence. To provide a ready supply of fluid for the daily peak demands, storage tanks are employed.

Although the steam demand for the Pine Creek tungsten process is rather constant, heat demands for other end uses are prone to daily fluctuations. Both process heat for the mill and space heat for the office buildings may require daily changes in heat demand. Thus a storage tank will be employed to handle demand fluctuations of the geothermally heated hot water on a day-to-day basis. An insulated storage tank will provide a reservoir of hot water for increases in demand whenever they may occur.

\subsubsection{Materials Evaluation}

\subsubsection{Pipe Materials}

A preliminary investigation into the different types of pipe materials would indicate quite a wide variety from which to choose. The basic criteria in choosing the best pipe-insulation conduit combination would be: (1) the pipe must meet the requirements of the heat transfer medium, i.e., the pipe must not be adversely affected by the medium's temperature, pressure, or chemistry; (2) the insulation must properly limit thermal losses or gains; (3) if placed underground, some form of encasement must protect the pipe and insulation from external loads and the underground environment; and (4) the cost-benefit ratio for the pipe-insulation conduit combination must be examined in relation to the medium being transferred.

There are, of course, many other factors to be considered such as heat transfer characteristics, thermal expansion, creep strength, and corrosion protection. Some of the different types of pipe materials are listed in Table 2-1, which gives a brief description of the characteristics of each.

Mild steel is the most commonly used material in prefabricated pipe and conduit casing because of its relatively low cost, availability, and ease of fabrication. Carbon steel pipe for brine transmission has been successfully used in the past. Proper precautions must be taken, however, to prevent pitting and crevice corrosion especially by geothermal brine. High salinity geothermal fluids will cause high uniform corrosion as well as localized corrosion.

Preinsulated pipe using non-metallic materials of the asbestos-cement or fiberglass reinforced plastic (FRP) type appears to be popular for geothermal district heating systems. Preinsulated pipe, very simply, is a prefabricated pipe usually from 


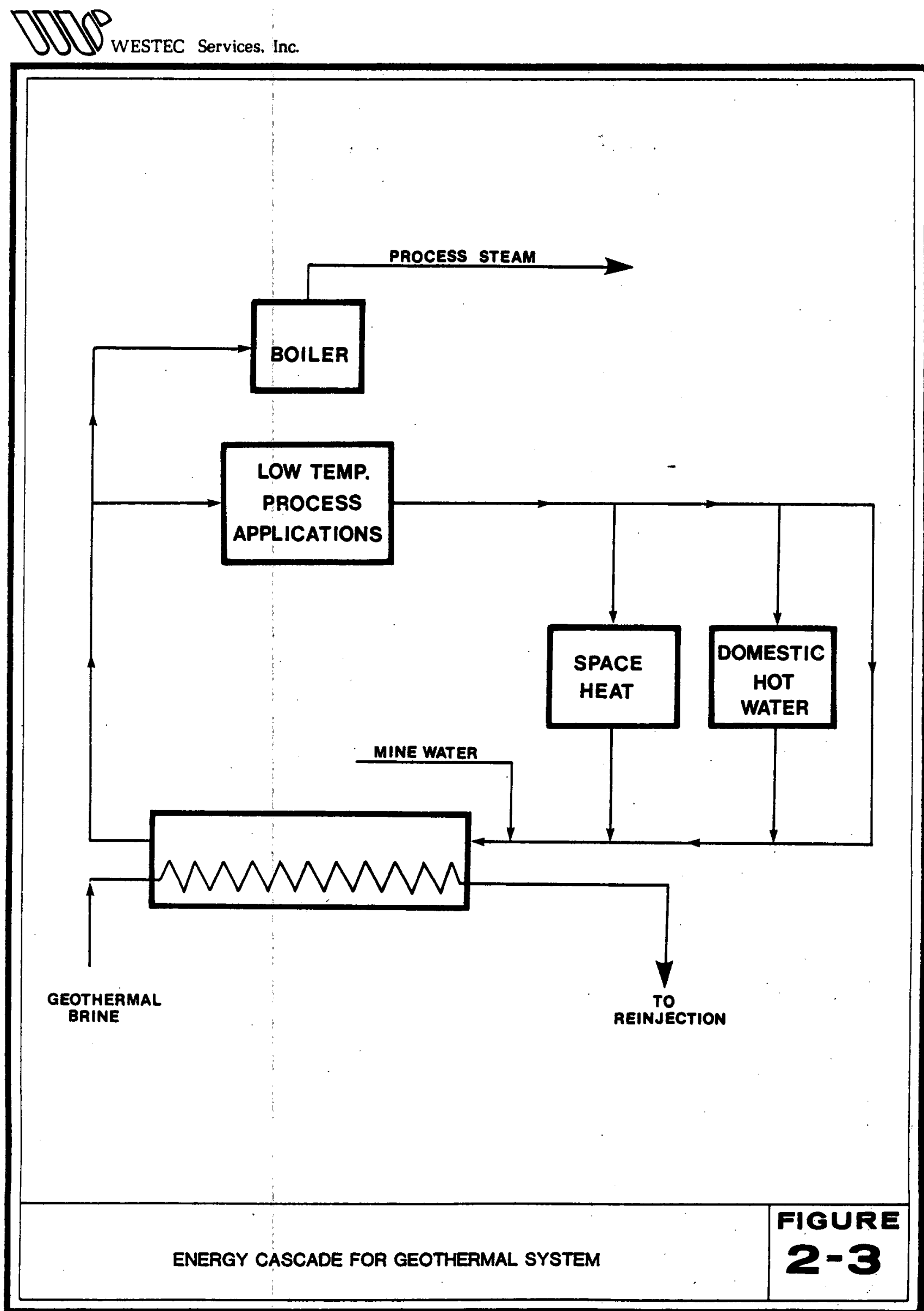


Table 2-1

PIPING MATERIALS

FERROUS METALS

Cast Iron

Wrought Iron

Low Carbon Steel

Stainless Steel
$-: \quad$ Wir

used in water and sewer lines

High resistance to atmospheric and soil corrosion

- Are comparatively brittle but have acceptable strength

- Highly corrosion resistant

- Expensive

- Widely used in various applications

- Good for low and medium pressure steam \& water

- Rather economical

- Easy to weld

- Low corrosion resistance

- Highly corrosion resistant

- Very expensive

\section{NON-FERROUS METALS}

Note: The use of these materials is confined to within buildings. They are not used extensively in underground mains for thermal conveyance systems.

\begin{tabular}{l|ll} 
Copper & - & $\begin{array}{l}\text { Widely used for indoor plumbing } \\
\text { Good corrosion resistance } \\
-\end{array}$ \\
Aluminum & - & $\begin{array}{l}\text { Highly expensive } \\
-\end{array}$ \\
Brass, Bronze & $\begin{array}{l}\text { Good corrosion resistance } \\
\text { NON-METALLIC MATERIALS }\end{array}$
\end{tabular}

Asbestos-cement

Concrete

Fiberglass Reinf orced Plastic (FRP)

Thermoplastics

Thermosetting Resins
- $\quad$ Of ten used in water lines

- Low friction losses

- Good strength

- Highly brittle

- Sizes up to 36 in., pressures up to 200 psi, temperatures up to $200 \mathrm{~F}$

- Used for large water mains and sewer lines

- High flow coefficient

- Corrosion resistant

- Can withstand significant external loads

- Temperatures up to $300 \mathrm{~F}$

- Corrosion resistant

- Low friction losses

- Lightweight

- Easy to install

- Good strength

- Temperatures up to $200 \mathrm{~F}$

- Pressures up to 100 psia

- Relatively low strength

- Can be used as liner for other pipe materials

- Good corrosion resistance

- Good for low temperature water service 
10 feet to 13 feet in length, which contains an inner core (copper, asbestos-cement, steel, or PVC), insulating material around this core (polyurethane foam or calcium silicate), and an outer casing (asbestos-cement or PVC). Because all of the components are packaged into a pipe spool at the factory, the cost per unit length is relatively inexpensive. Besides this main advantage, the prefabricated system is fast and easy to install.

While preinsulated pipe has certain advantages which make it suitable for district distribution systems, it may not be suitable for the Pine Creek mill situation. First of all, preinsulated pipe is good for long straight runs where its ease of installation saves greatly in cost. In the Pine Creek project this is not required if it is assumed that the well is at the mill site. In addition, pipe materials of the asbestos-cement variety are limited to maximum working temperatures of around 200F. FRP pipe can take temperatures up to $300 \mathrm{~F}$ but requires more time for installation because each spool must be glued together.

It appears that for the Pine Creek mill, carbon steel pipe would suffice for both the brine loop and the freshwater loop with proper insulation. Carbon steel pipe is relatively inexpensive, readily available, and holds up surprisingly well in geothermal applications. Carbon steel pipe has been extensively used in all types of brine, and carbon steel can handle a wide range of temperature and pressure conditions.

\subsubsection{Insulation}

An ideal material for insulation service should be: (1) capable of withstanding repeated wetting and drying without serious deterioration; (2) non-corrosive to pipe materials when wet; (3) a nonconductor of electricity; (4) vermin proof; and (5) chemically and physically stable at operating temperatures.

Insulation materials basically fall into four temperature ranges-cryogenic (below to $-150 \mathrm{~F})$, low temperature $(-150 \mathrm{~F}$ to $250 \mathrm{~F}$ ), moderate temperature (250F to $1200 \mathrm{~F}$ ), and high temperature (above $1500 \mathrm{~F}$ ). Insulation types include calcium silicate, fibrous and cellular glasses, urethane foam, rock and mineral wools, expanded perlite, ceramic brick, and various fibers (mineral, ceramic, oxide, carbon). Physical forms of insulation can be loose-fill, flexible, rigid, reflective, and formed in place; forms can be foam, blocks, blankets, granular, mats, boards, and tape.

Of the abundant variety of materials from which to choose, fiberglass, calcium silicate, and polyurethane foam appear to be the most widely used in geothermal applications (see Table 2-2).

Polyurethane foam is an organic plastic which is confined to the lowtemperature application range. This material comes in blocks, boards, flexible sheets, or can be foamed in place. It has also been widely used in preinsulated pipe for low temperature geothermal brine service. Polyurethane has a very low conductivity factor, making it one of the best materials in this category. Unfortunately, permeability to water vapor has been a problem with polyurethane foam in cryogenic service. Water vapor penetrates the foam and deposits ice when it freezes, destroying the insulation properties. 
Table 2-2

PROPERTIES OF GEOTHERMAL INSULATING MATERIALS

Temp. range

Conductivity, $\mathrm{K}$

Btu-in/hr- $\mathrm{ft}^{2}-{ }^{\circ} \mathrm{F}$

Density, lb/ft ${ }^{3}$

Compressive strength lb/in ${ }^{2}$ a $\%$ deformation

Relative cost
Calcium

Silicate

$100 \mathrm{~F}$ to $1500 \mathrm{~F}$

0.33 to 0.72

10.0 to 14.0

100 to 250

a 5\%

high
Fiberglass

$-120 \mathrm{~F}$ to $650 \mathrm{~F}$

0.15 to 0.54

0.60 to 3.0

0.02 to 3.4

(a) $10 \%$

low
Urethane

Foam

$-250 \mathrm{~F}$ to $225 \mathrm{~F}$

0.11 to 0.14

1.6 to 3.0

16 to 100

a.5\%

low

Fiberglass is formed from fine, resilient glass fibers. It has been used in service up to $650 \mathrm{~F}$ in temperature. Fiberglass most popularly comes in blankets, semirigid boards, and molded sections. In blanket form, fiberglass is easy to install around pipes and tanks. Although fiberglass does not have the compressive strength of either polyurethane foam or calcium silicate, it does have excellent thermal resistivity and is relatively cheaper than calcium silicate for moderate temperature use.

Calcium silicate is a mixture of lime and silica reinforced with organic and inorganic fibers. It is used up to $1500 \mathrm{~F}$ temperatures. It comes in boards and blocks, and quarter-round and half-round segments for pipes. Because of its rigidity, this material has a higher resistance to mechanical abuse than most insulating materials. A typical aluminum jacketing around the insulation provides protection against weather and other damage.

\subsubsection{3 $\quad \underline{\text { Conduit }}$}

Conduit envelopes protect pipe and insulation against wetness, corrosive soils, and mechanical loads. The two basic types of conduit are: (1) poured field constructed type; and (2) prefabricated type. Both types can be either pressure tight or non-pressure tight. Many of the poured envelopes incorporate a combination cementinsulation or insulating cement which is poured around the pipes. Others use a hydrocarbon envelope of a natural granular asphaltic material of high resin content, or asphalt contained in a metal jacket surrounding the pipe.

Because field constructed conduits are more costly than factory prefabricated conduit sections, which can be easily assembled at the site, examination of the prefabricated conduit types is in order. 
Prefabricated pressure tight steel conduit can be made of either smooth or corrugated steel. The pipe is surrounded with preformed insulation and then the conduit is placed around it with a drain space in between. A coupling is welded to join two sections of conduit; a protective coating, enamel or mastic is used to seal the joints. Sealed asbestos-cement conduits are similar in configuration to the prefabricated steel type except asbestos-cement is used for both the pipe and outer casing. Joints are made with compression type couplings and O-rings for sealing. Epoxy lining and polyurethane foam insulation is also used.

Also similar to this configuration is fiber-reinforced plastic conduit using FRP pipe with polyurethane insulation. Sections are joined by use of a bonding cement or mastic.

\subsubsection{Heat Exchanger Materials}

In the binary heat extraction process, well site heat exchanger(s) would be called upon to transfer heat between the geothermal reservoir fluid (estimated at approximately 240F, 116C) and the freshwater taken from the Pine Creek mine (at approximately $40 \mathrm{~F}, 4 \mathrm{C}$ ).

A wide variety of materials can be used for heat exchangers. Tube materials range from mild steel and copper alloys, to expensive titanium. Mechanically, these materials have high strength combined with excellent ductility so that they can be handled with reasonable care without bending, kinking, becoming dented or otherwise damaged.

Copper alloys are prone to chemical attack by copper embrittlement due to the $\mathrm{H}_{2} \mathrm{~S}$ (hydrogen sulfide) in the geothermal brine. Cracking of some copper-based alloys exposed to ammonia or its derivatives also may occur.

Titanium and titanium-based alloys tested on geothermal fluids have shown excellent results in resistance to corrosion, impingement, and cavitation damage. Titanium is relatively expensive and experiences with cheaper carbon steel material have been quite positive.

Tests have been conducted on heat exchanger tube materials under experimental conditions at a Heber Reservoir site. Results taken from tests at Heber's Nowlin No. 1 Well have shown that carbon steel or titanium tubes can be considered for service at Heber if proper precautions are taken to prevent excessive exposure to air (oxygen) during startup, shutdown, and maintenance operations. Tests performed at an East Mesa geothermal well site have also shown positive results utilizing carbon steel tubes. After formation of a tenacious layer of magnetic iron oxide, corrosion appeared to have ceased. No signs of pitting or flaking of the oxide were apparent. Copper nickel $(90: 10)$ proved to function satisfactorily in lower temperatures but in hotter temperatures corrosive attack was excessive. Titanium tubes showed no signs of corrosion or other damage. 


\section{REFERENCES}

Christiansen, Chris C., June 1978, Self-Start Manual for Direct Use Applications of Geothermal Resources, work performed under DOE Contract EG-77-C-03-1329 and CEC Contract 500-014.

DeBerry, David W., Ellis, Peter F., and Thomas, Colin C., Materials Selection Guidelines for Geothermal Power Systems Radian Corporation, work performed under DOE Contract EG-77-C-04-3904.

Fassbender, Linda L. and Bloomster, Clarence H., Economics of Geothermal Fluid Transport, Pacific Northwest Laboratory under DOE Contract EY-76-C-06-1830.

Kunze, J.F., Lofthouse, J.H., and Stoker, R.C., The Potential for Utilizing Geothermal Energy for Space Heating in Reconstructed Sugar City, Idaho, prepared for Energy Research and Development Administration under Contract EY-76-C-07-1570.

Operation and Maintenance of the East Mesa Test Site, August 1977, final report Phase II, prepared |for U.S. Department of the Interior Bureau of Reclamation Contract 14-06-300-2622.

Sherwood, P.B., et al., September 1977, Engineering and Economic Feasibility of Utilizing Geothermal Heat from the Heber Reservoir for Industrial Processing Purposes at Valley Nitrogen Products Inc., El Centro Agricultural Chemical Plant, under DOE Contract EY-76-C-03-1323. 


\section{SECTION 3}

\section{DESIGN OF GEOTHERMAL ENERGY SYSTEM}

\subsection{INTRODUCTION}

Energy use at Pine Creek has been thoroughly examined, and end uses that are considered feasible with a low temperature resource have been pinpointed. The following section addresses the specifics of a geothermal energy system at Pine Creek, the associated equipment and the expected retrofit required.

\section{$3.2 \quad$ MECHANICAL EQUIPMENT}

\subsubsection{General}

The Pine Creek geothermal system is comprised of a brine and fresh water binary heat delivery system. The brine production, surface and injection facilities are shown in Figure 3-1. A submersible downhole pump will provide brine for the geothermal fluid side of the system at a peak load flow of $450 \mathrm{gpm}$. Two heat exchangers will be used to transfer heat from the geothermal brine to clarified mine water. After exiting the second heat exchanger, the spent brine will be injected with a centrifugal pump into a compatible aquifer through an injection well. The major system components and requirements for the proposed system are described in further detail below.

\subsubsection{Submersible Pump}

A downhole pump will be required to provide a sufficient fluid flow for the Pine Creek geothermal system. There are basically two types of pumps used for geothermal fluid production: the shaft-driven downhole pump and the submersible pump and motor. The lineshaft pumps are rather limited in the depth at which the pump can be placed. The maximum practical depth for pumping brine with lineshaft pumps is around 1000 feet although shallower depths are more common. The reliability of the shaft bearings becomes questionable as the depth and temperature are increased. The setting of the pump at Pine Creek is assumed to be 1000 feet. At this depth, a lineshaft pump would be operating in a marginal range, therefore, a submersible pump was decided on for this application.

After well conditions are known, the submersible pump should be sized to avoid marginal design efficiency. A pump that is incorrectly sized and operates substantially off peak pump capacity will result in excessive thrust bearing and impeller wear. Pumps operating in an off-peak condition can also accelerate cable wear. Without liquid to dissipate the heat, the temperature in the cable can become excessive, resulting in cable failure.

For preliminary design calculations, the desired discharge conditions were teamed with assumed reservoir data which resulted in determination of specific well parameters that would fit the design criteria. A setting depth of 1000 feet was chosen with an anticipated wellhead pressure of 100 psig which will provide the brine system pressure and the pressure required to overcome friction losses. 


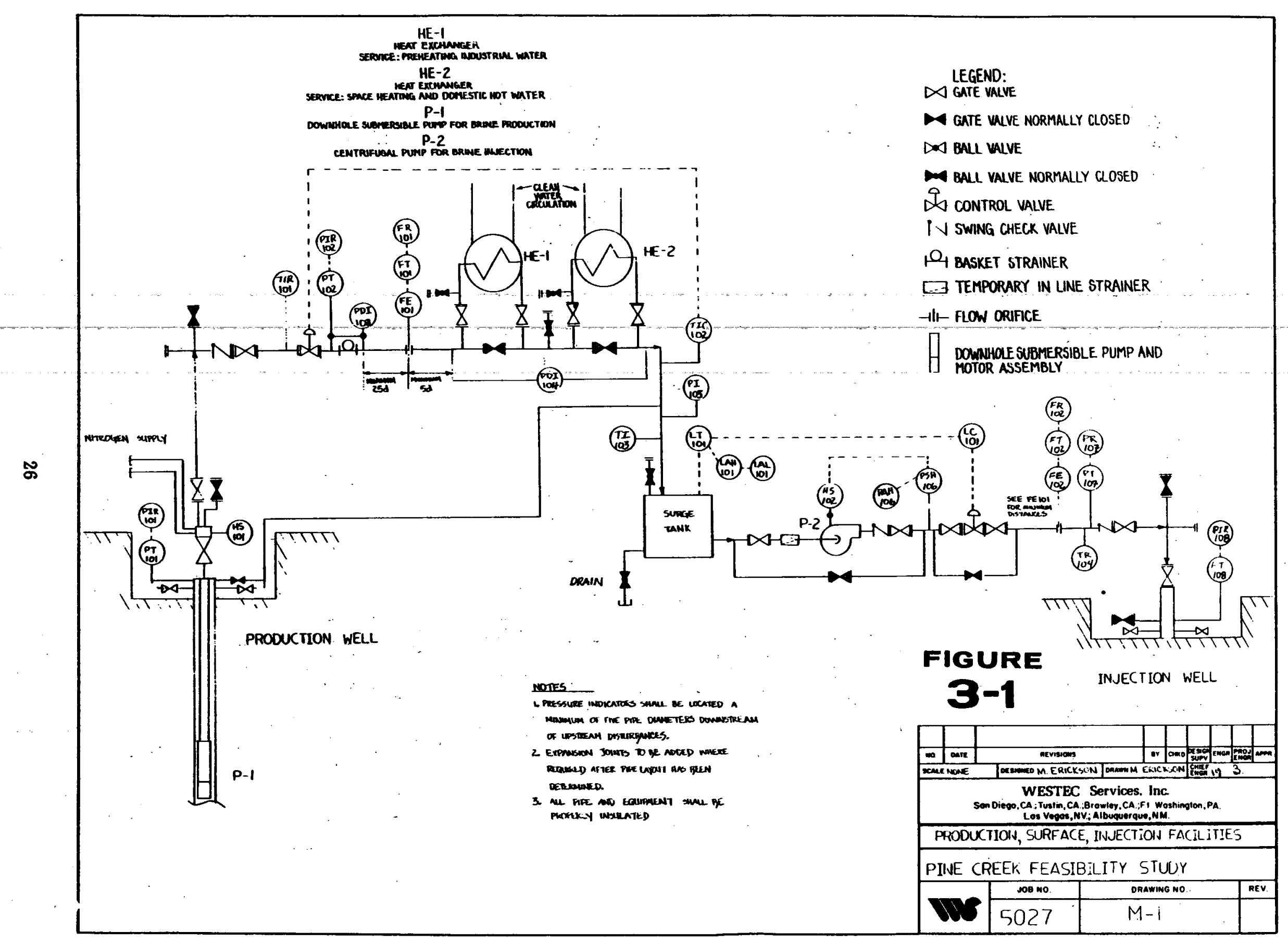




\subsubsection{Heat Exchangers}

Fluid extracted from a reservoir at the Pine Creek location is expected to be fairly clean with a small component of dissolved solids in the brine. Carbon steel will be used for all piping and in the heat exchangers as a significant corrosion problem is not anticipated. The $\mathbf{3 6 5}$ day fouling factor for the brine side of the heat exchanger should not exceed .0012 based on tests conducted on carbon steel heat exchangers at the geothermal Heat Exchange Test Unit (HETU) in Heber, California (Ghormley, 1978). This fouling factor was based on a brine temperature range of $180-145 \mathrm{~F}$.

The heat exchangers will be arranged in series and will be of the standard shell and tube design. The first heat exchanger will be used for preheating the industrial water, with an annual load of $1.8 \mid \times 10^{18} \mathrm{Btu} / \mathrm{yr}$. As the geothermal brine passes through the industrial water heat exchanger, the temperature of the brine drops from $115 \mathrm{C}$ to $109 \mathrm{C}(240 \mathrm{~F}-228 \mathrm{~F})$, assuming a flow of $450 \mathrm{gpm}$ on the brine side.

For space heating, the peak load demand is approximately $8.3 \times 10^{6} \mathrm{Btu} / \mathrm{hr}$. After passing through the industrial water heat exchanger, the brine heats clarified water for use in space heating and domestic hot water heating. The brine enters the heat exchanger at $115 \mathrm{C}$ and after giving up energy for space heating, exits the second heat exchanger at $87 \mathrm{C}$.

The predicted temperature of the brine at the wellhead is $121 \mathrm{C}(250 \mathrm{~F})$. With the use of a downhole pump, the predicted flow rate from the production well is 450 gpm. A pump placed in the production well will not only provide the necessary fluid flow, but will pressurize the brine transmission system to prevent brine flashing from taking place in the production pipeline or heat exchangers.

\subsubsection{Existing System}

The layout of the Pine Creek tungsten mining complex is shown in Figure 3-2. This shows the relative location of the office building and the office building annex to the mine and mill change rooms that will be heated with a geothermal energy system. The tungsten mill itself generally does not require direct space heating. Heat radiated from steam pipes and process equipment provides adequate space heating within the mill buildings. An energy profile of the Union Carbide mining complex is shown below in Table 3-1.

Gasoline and diesel are used exclusively as fuel for mobile equipment. These energy requirements do not seem adaptable to geothermal energy use or any other type of current alternative energy substitution. Electrical generation is not feasible with a low temperature resource; but it is estimated that $45 \times 10^{10}$ Btu/yr supplied currently by fuel oil could be replaced if geothermal brine is used as an energy input. 


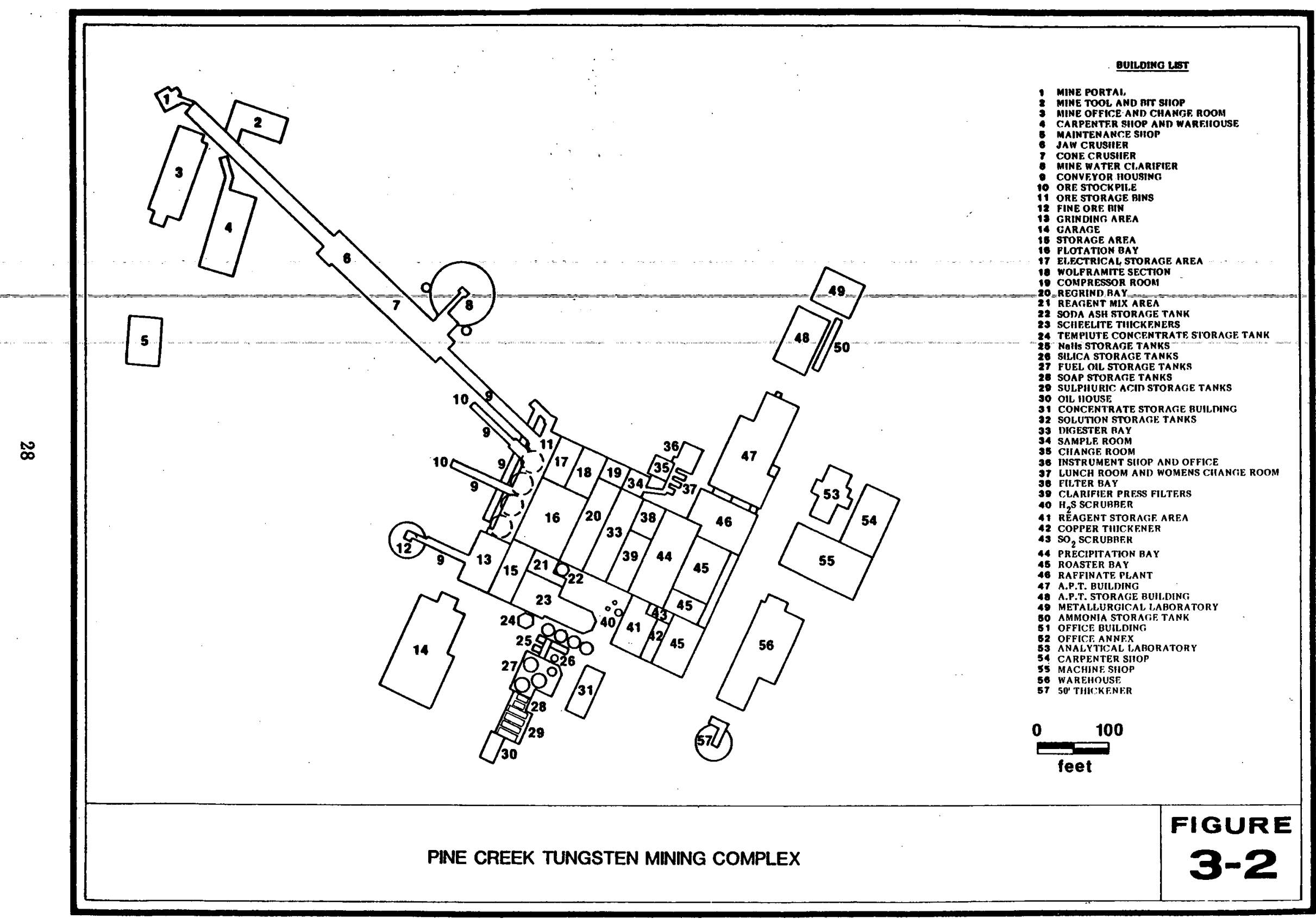


Table 3-1

ENERGY CONSUMPTION AT UNION CARBIDE'S TUNGSTEN MINING COMPLEX

\begin{tabular}{lrrrr} 
& $\frac{9}{19}$ & \multicolumn{1}{c}{ Btu/yr } & $\frac{\mathrm{kwh} / \mathrm{yr}}{}$ \\
Electricity & 19 & $1.22 \times 10^{11}$ & $3.6 \times 10^{7}$ \\
Gasoline & 1 & $6.3 \times 10^{9}$ & $1.8 \times 10^{6}$ \\
Diesel & 5 & $3.3 \times 10^{10}$ & $9.7 \times 10^{6}$ \\
Fuel Oil & $\frac{75}{100}$ & $\frac{4.7 \times 10^{11}}{6.3 \times 10^{11}}$ & $\frac{1.4 \times 10^{8}}{1.9 \times 10^{8}}$ \\
TOTAL: & 100 & $6.3 \times 10^{2}$ &
\end{tabular}

\subsubsection{Mine and Mill Change Rooms}

The change rooms at the Pine Creek tungsten complex are currently heated via a steam distribution system that supplies steam to radiators within the mine and mill change rooms. A typical piping schematic for the steam supply and condensate return is shown in Figure 3-3. Currently two steam radiators heat the mill change room and ten radiators heat the mine change room.

\subsubsection{Office Building}

The office building that houses the professional and administrative personnel is heated by a furnace which burns fuel oil. The furnace burns 2186 gallons of fuel oil per year during the winter months. The building is normally occupied nine hours a day during the week and five hours each day on the weekends. Forced air supplies heat to the entire building. This two story office building has walls constructed of stucco and wood with $\mathrm{R}-11$ fiberglass insulation.

Heat flux from the buildings was calculated using selected representative values of heat transfer coefficients for the various types of construction. These heat flux calculations were made with the assumption that exemplary conditions of components and installation are present in the building construction, and there are no free air cavities within the construction. An example of the heat flux calculations and thermal analysis of the wall construction is contained in Appendix A.

\subsection{GEOTHERMAL ENERGY APPLICATIONS}

\subsubsection{Space Heating}

A binary system was chosen for space heating the office buildings and the change rooms. The proposed space heating/water heating system is basically a closed water loop that obtains its energy input from geothermal brine in a liquid-liquid heat 


\section{NUP wESTEC Services. Inc.}

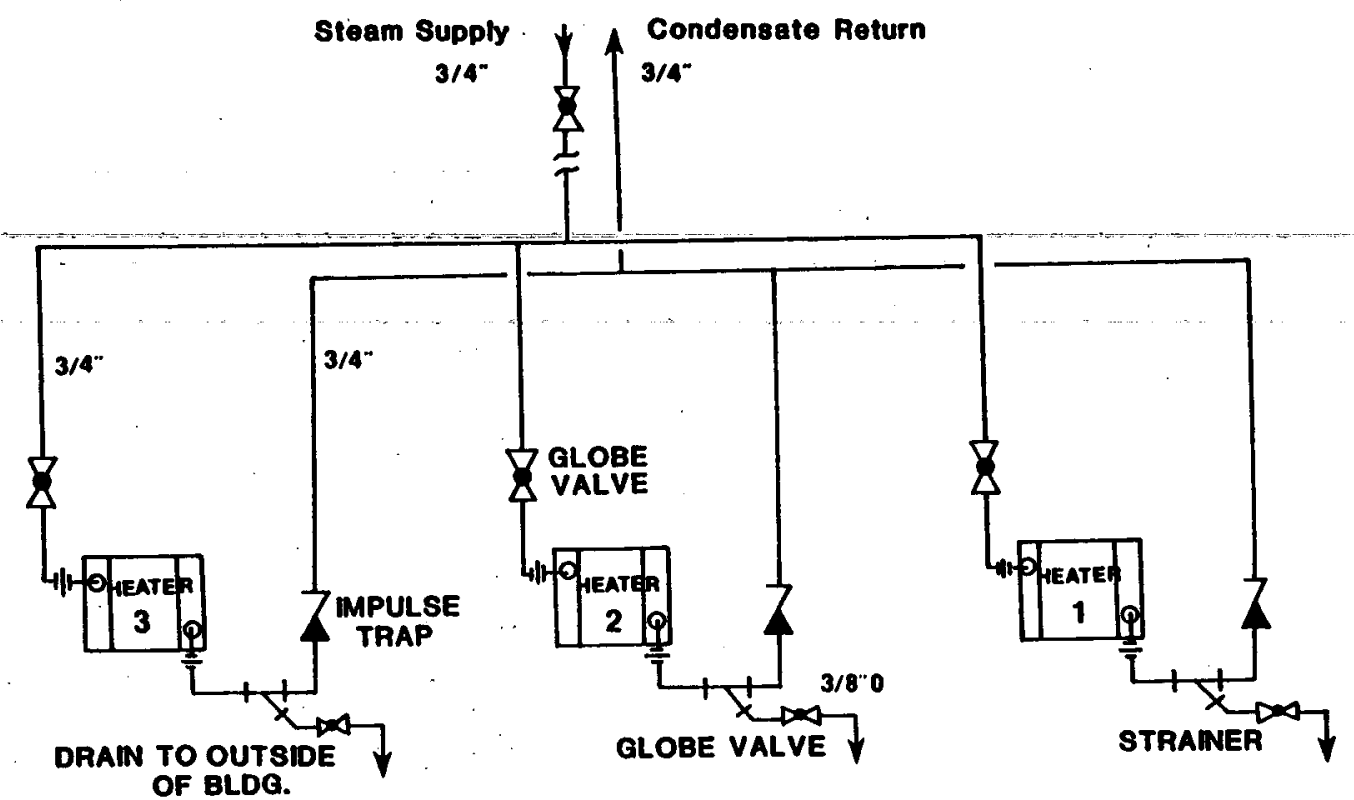


exchanger (see Figure 3-4). Clean water acting as the secondary fluid passes through the heat exchanger obtaining on outlet water temperature of $85 \mathrm{C}(185 \mathrm{~F})$.

A small circulation pump is required for the clean water loop that will keep the water pressurized and flowing through the system. After obtaining a heat input from the brine, the clean heated water passes through heating coils where forced air circulation through the coil unit provides space heating to the rooms. After leaving the heating coils, the relatively cool water $(63 \mathrm{C}, 146 \mathrm{~F})$ is cascaded to heat domestic hot water for office use.

\subsubsection{Domestic Hot Water}

A temperature controller on the hot water tank maintains domestic hot water temperature between the band of 50-60C (122-140F). If the temperature in the water tank is below $50 \mathrm{C}$, the three-way control valve directs the discharge from the heating coils through the hot water tank until a maximum temperature of $60 \mathrm{C}$ is reached. When the temperature of the tank attains a temperature of $60 \mathrm{C}$, the three way valve closes the path through the water heater and bypasses it. This should conserve the greatest possible amount of heat in the clean water loop which will reduce the heat input demand from the geothermal brine.

A temperature controller will be installed on the brine circulation loop immediately after the brine exits the second heat exchanger. This temperature controller will control the exit temperature from the heat exchangers between 65-75C (150-167F) by modulating a control valve on the brine supply from the geothermal production well. This should reduce the amount of fluid pumped by the downhole production pump, thus reducing operation costs of the system.

\subsubsection{Industrial Boiler Water Preheat}

The system will consist of a brine/water heat exchanger which will heat clarified mine water from an inlet temperature of $4 \mathrm{C}(40 \mathrm{~F})$ to an outlet temperature of $85 \mathrm{C}(185 \mathrm{~F})$. Because 78 percent of the steam generated by the boilers is injected into the tungsten processing stream, the clean water in this system passes through the heat exchangers only once. This heat exchanger unit will require no major modifications of the present plant configuration. Immediately before entering the tungsten mill, the clarified water will enter the designated heat exchangers and then follow the same path that it currently follows.

No unusual problems are anticipated with this new system design. Although the fluid entering the boiler feedwater pumps will have a higher vapor pressure because of its higher temperature, the water will be under a slightly greater pressure which should prevent any potential cavitation problems in the boiler feedwater pumps. Because the proposed modifications maintain the design of a closed system, the supply pump in the clean water system should be adequate for providing the positive suction head required for the boiler feedwater pumps.

\section{$3.4 \quad$ UTILIZATION FACTORS}

The proposed geothermal energy system will have a high year-round load factor. The tungsten mill processes raw tungsten ore to ammonium paratungstate 


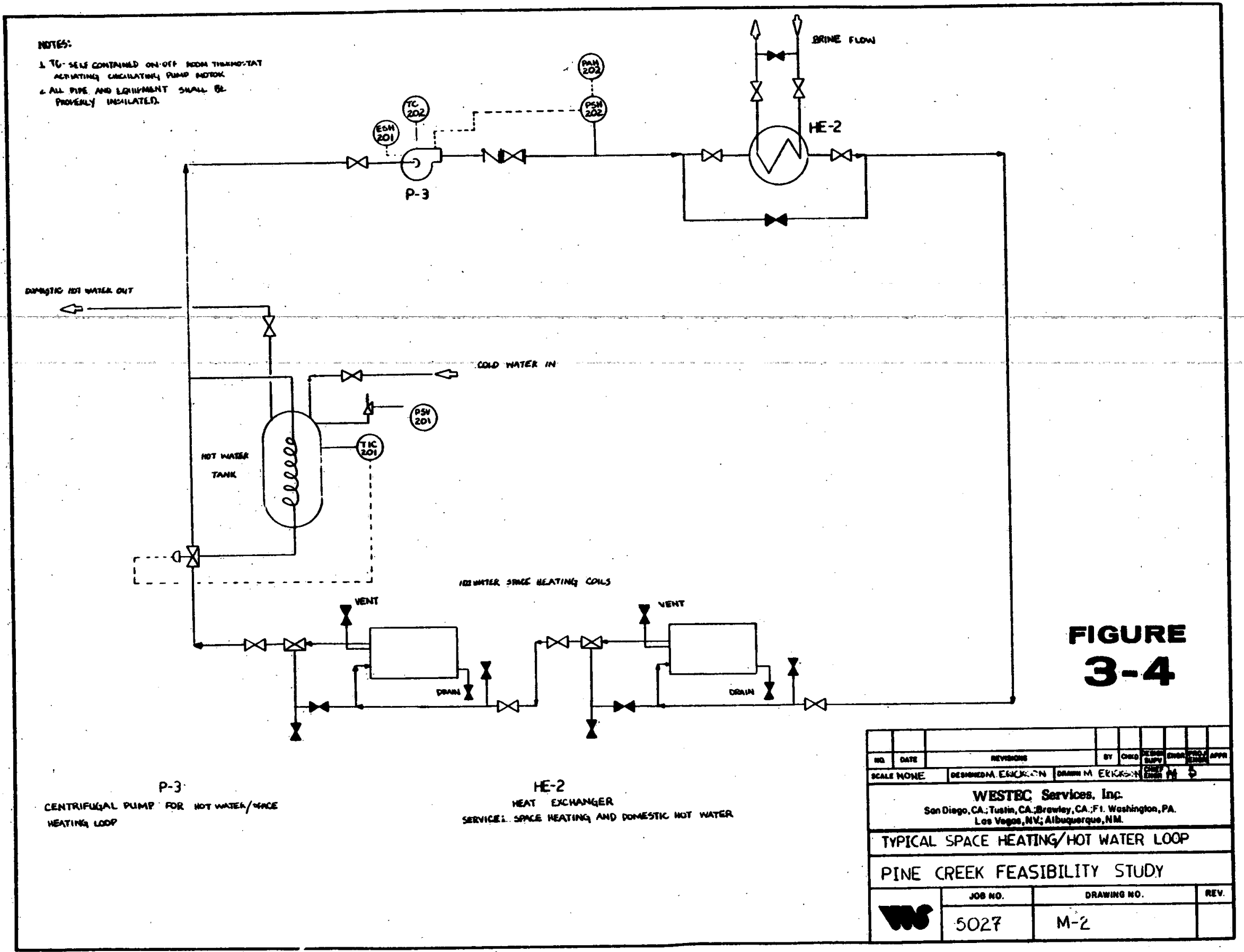


24 hours a day. Although some system loads such as space and domestic water heating will fluctuate with building occupancy, the industrial water demands will maintain a high utilization factor for the overall geothermal system resulting in a lower unit cost of energy supplied to the Pine Creek tungsten complex.

If the geothermal system is sized for peak loads (which would normally occur during winter months) the annual utilization factor should approach 40 percent. If an increase in the utilization factor is desired, the system could be sized so that it provides all of the energy input possible for the industrial water demand, and a portion of the energy input for space heating. This design would necessitate incorporation of a hybrid system sized to supply all of the space heating required on an average winter day, and for colder temperatures oil heaters could be used to boost the temperature sufficiently.

Another possibility would be the use of heat pumps for amplification of the heat supplied by the geothermal system. A more thorough analysis of the temperature fluctuations and the percentage of time the temperature is within specified narrow temperature ranges is required to use these types of geother mal "boost" systems. Temperature monitoring would be required at the Pine Creek site to establish a baseline for average winter conditions and space heating loads. This information would allow determination of the fraction of the annual total heating needs that must be supplied by a supplementary furnace or boiler and the fraction of the heating season that the supplementary boiler would need to operate at complete or partial load. 


\section{REFERENCES}

ASHRAE Handbook and Product Directory, 1977, American Society of Heating, Refrigerating and Air Conditioning Engineers, Inc.

Centrilift, Inc., 1978, Handbook for Oilfield Subsurface Electrically Driven Pumps, 2nd edition.

Crane Company, 1973, Flow of Fluids Through Valves, Fittings and Pipe.

Ghormley, Edward L., Stern, Jay L., et al., August 1978, Geothermal Heat Exchanger Test at Heber California, Electric Power Research Institute, ER-572 Research Project 846-1.

Holman, J.P., 1976, Heat Transfer, McGraw Hill, Inc.

Sherwood, P.B., et al., April 1979, Multi-Purpose Utilization of Hydrothermal Resources Within the City of El Centro, under DOE Contract ET-78-C-03-1741. 


\section{SECTION 4}

\section{ECONOMICS}

\subsection{INTRODUCTION}

A preliminary economic evaluation was undertaken for geothermal system development on the project site at Pine Creek. The use of geothermal brine as an energy source for space heating, domestic water heating and a portion of industrial water heating was compared to current conventional energy sources to determine the economic feasibility of geothermal energy substitution at the tungsten mining complex. The analysis was conducted by comparing capital recovery charges for the proposed geothermal energy system with the projected savings of conventional fuel charges over the study period. Capital cost estimates were taken in part from Richard Engineering Services, Inc. Estimating Standards copyright 1979.

\subsection{ECONOMIC INCENTIVES}

\subsubsection{Introduction}

The economic analysis for a geothermal energy system must include an evaluation of cash flows that will show that the annual savings of the proposed project will justify the front-end capital investment. Capital investment must be encouraged so that technical progress is achieved that will promote improvement of the standard of living. The United States Government has taken action to reduce the deterrent to capital formation in general, and has implemented laws to advance alternative energy development.

The tax and economic incentives described in further detail below promote geothermal development as they reduce the financial liability of the geothermal developer. Additional favorable legislation has been proposed to the United States Congress that would further increase the attractiveness of investments for geothermal utilization.

\subsubsection{Tax Incentives}

\subsubsection{Investment Tax Credit}

In 1962 tax laws were revised to alleviate some of the undesirable effects of income taxation on capital investment. One of these actions involved shortening the estimated lives of depreciable property acceptable for tax purposes. This permits a larger fraction of the total depreciation to be written off in the early years of the project. The other major legislative action that reduced the tax deterrent to capital investment was the establishment of an "investment tax credit" (Grant et al., 1976). The investment tax credit allowed businesses to deduct from their income taxes a stipulated percentage of the qualified investment. With certain exclusions, the eligible property included tangible personal property subject to depreciation. This credit is a reduction of the tax assessed by the government rather than a reduction in the taxable income. 
The Energy Tax Act of 1978 provides a business investment tax credit for investment in "energy property." This credit is in addition to other tax credits for which the taxpayer may be eligible. This definition specifically encompasses "equipment used to produce, distribute or use energy derived from a geothermal deposit." For investments in energy property made between January 1, 1980 and December 31, 1989, the credit will be 15 percent.

\subsubsection{Intangible Drilling and Development Costs}

The Internal Revenue Code Section 263(c) allows the taxpayer at his option to deduct intangible drilling and development costs of geothermal wells. The Energy Tax Act of 1978 extends this tax advantage to geothermal developers which was previously available only to oil and gas well developers.

Under this provision, the taxpayer may elect to deduct these intangible costs from taxable income in the year that the costs were incurred as opposed to capitalizing them. This option is applicable to all expenditures incurred by the developer for wages, fuel, repairs, hauling, supplies, etc. incident to and necessary for the drilling and preparation of wells for geothermal production. In general, intangible drilling and development costs are those items which in themselves have no salvage value.

\subsubsection{Other Financial Incentives}

\subsubsection{Percentage Depletion}

The Energy Tax Act of 1978 granted geothermal developers the right to use the percentage depletion allowance previously allowed for oil and gas for geothermal deposits in the United States or its posessions. The taxpayer may deduct 22 percent of gross income for depletion in 1980, 20 percent in 1981, 18 percent in 1982, 16 percent in 1983 and 15 percent in 1984 and thereafter. These percentages are subject to an overall limitation: the allowances for depletion may not exceed 50 percent of the taxpayer's taxable income from the property.

The tax advantage of the percentage depletion allowance for geothermal reservoirs is that the taxpayer may deduct the statutory percentage from gross income sach year that the property produces income. In contrast, cost depletion allowance, allows no further deduction after the capital investment has been recovered. If the property on which geothermal development has begun is sold, the new owner of a geothermal proven property can continue to take percentage depletion.

\subsubsection{Geothermal Loan Guaranty Program}

The Department of Energy administers a program to guaranty lenders against loss of principal and accrued interest on loans for specified aspects of geothermal development, including acquisition of rights to geothermal resources, determining and evaluating the resource, research and development respecting extraction and utilization, and construction and operation of a new commercial or industrial facility or modification of an existing facility when hot water is to be used within such facility for industrial purposes. All of these aspects would be relevant regarding Pine Creek. 
The federal regulations promulgated by the Department of Energy, effective December 18, 1979 state that the amount guaranteed on each project cannot exceed $\$ 100,000,000$. A single borrower cannot obtain guarantees in excess of $\$ 200,000,000$. The amount guaranteed cannot exceed 75 percent of the estimated total cost of the project. The Department of Energy determines what the rate of interest will be. Before a loan guaranty will be granted the applicant must present satisfactory evidence regarding environmental impact. Issuance of the guaranty is subject to the provisions of NEPA.

The maximum time for repayment of a federaly guaranteed loan is 30 years. The loan guarantees are only available if the agreement is entered into by September 3, 1984.

\subsubsection{User Coupled Confirmation Drilling Program}

This is a new program of the DOE, Division of Geothermal Energy. Through this program, the federal government will cost share 20-90 percent of the expenses incurred during exploration to site drill holes, drilling, flow testing, reservoir engineering and injection well drilling. The percentage of costs that the government will support decreases as the success of the project increases.

\subsubsection{Geothermal Energy Act of 1980}

Title VI of the Energy Security Act (P.L. 96-294) entitled the Geothermal Energy Act of 1980 establishes financial assistance programs in DOE to promote exploration and confirmation of geothermal reservoirs, and provides funding for feasibility studies and construction of specific geothermal projects.

Under Subtitle $\mathbf{A}$, a total of $\$ 85$ million in Federal loans and loan guarantees for geothermal reservoir confirmation is authorized for Fiscal Years 1981 to 1985 (including \$5 million for FY 1981 and \$20 million for each fiscal year 1982 through 1985). In addition, $\$ 5$ million is authorized for feasibility studies (Subtitle C) in FY 1981. Funding for construction loans is deferred until FY 1982.

DOE is also directed to conduct a reservoir insurance study in cooperation with the insurance and reinsurance industry (Subtitle B).

A number of other amendments were made to ease the regulatory burdens on small geothermal plants of less than 80 megawatts and to provide special help for direct heat utilization projects.

\subsection{CONVENTIONAL ENERGY COSTS}

In any analysis comparing alternative and conventional energy sources, a model must be constructed that will be capable of giving price projections for conventional fuel sources over the life of the study period. The economic feasibility of a geothermal project is largely dependent on the price escalation of fossil fuels. Forecasting is at best an uncertain science, which is further complicated by erratic foreign policy and an artificially tight supply of conventional fuels. Economic pressures on 
many major oil exporters are minimal as world oil prices are currently far above production costs of the key suppliers in the Middle East. Recent months have shown conventional fuel prices the victim of dramatic price increases due to fluctuation in prices and supplies from foreign oil producers.

The changing energy situation that confronts the United States is forcing an appraisal of energy use patterns based on overall energy conservation and economic principles. The Pine Creek feasibility study relies on projections of fuel prices over the expected 30 year life of the project equipment and the geothermal reservoir. Economic modeling becomes less reliable as it is extended further into the future. Unknown forces on the marketplace could radically alter current price trends and change the economic assessment of the project. Inflation rates associated with conventional fuel prices should be conservative to minimize financial risk. Available reports on fuel cost escalation are reluctant to predict the price of petroleum fuels because of the possible evolution of the petroleum supply picture.

Predictions of prices for petroleum fuels beyond 1985 are tentative and scarce. Events expected to influence the market price include perfection of shale oil extraction techniques, production of synthetic fuel from coal and solid wastes, alternative energy development, the load factor of the Alaskan pipeline, the ability of nuclear power plants to relieve the demand on fossil fuel for electrical generation and conservation.

A summary of conventional fuel costs are shown below in Table 4-1:

Table 4-1

\begin{tabular}{|c|c|c|c|}
\hline Source & Consumption & Cost & Unit Cost \\
\hline Electricity & $36,573,000 \mathrm{kwh} / \mathrm{yr}$ & $\$ 1,352,000$ & $\$ .037 / \mathrm{kwh}$ \\
\hline Fuel Oil & $3,894,000 \mathrm{gal} / \mathrm{yr}$ & $\$ 1,830,000$ & $\$ .470 /$ gal \\
\hline Gasoline & $54,230 \mathrm{gal} / \mathrm{yr}$ & $\$ \quad 40,130$ & $\$ .740 / \mathrm{gal}$ \\
\hline Diesel & $233,000 \mathrm{gal} / \mathrm{yr}$ & $\$ 137,500$ & $\$ .590 / g a l$ \\
\hline
\end{tabular}

The fuel oils used at Pine Creek are \#4 and \#6, middle distillates used for fuel for the boilers and the office furnace. For direct heat applications at this location geothermal energy will replace energy currently supplied by fuel oil. Fuel oil available at contract prices to industrial users were evaluated for constant dollar price escalations over the 30 year study period based one price forecast by San Diego Gas \& Electric, one from Fuel Cost Escalation Study (Kappelman et al.) and raw energy cost 
data from the Federal Register. The following assumptions were made in determining the constant dollar fuel costs:

$$
\begin{array}{lll}
-1 & \text { January } 1980 \text { price }-\$ 27.00 / \text { barrel } & \$ .64 / \text { gal } \\
\text { - } & 1 \text { January } 1981 \text { price }-\$ 39.15 / \text { barrel } & \$ .93 / \text { gal }
\end{array}
$$

Two scenarios for price projections are listed below

1. Price escalation for the following years

$$
\begin{aligned}
& 1981-20 \text { percent } \\
& 1982-14 \text { percent } \\
& 1983-7 \text { percent } \\
& 1984-7 \text { percent } \\
& 1985 \text { and thereafter } 9 \text { percent }
\end{aligned}
$$

2. 7 percent until 1985

4 percent after 1985

\subsection{ECONOMIC EVALUATION}

No major plant modifications are proposed for inclusion of a geothermal energy system at the Pine Creek complex. Therefore, costs for operation and maintenance of the tungsten processing mill are considered as being constant for both maintaining the existing system or using a geothermal energy system. The incremental operation and maintenance costs for the geothermal system is assumed to be 5 percent of the capital cost of the sytem per year.

Project feasibility for the first price scenario used a 20 percent rate of return because the economic projections favor alternative energy use because of the rapid price escalation of conventinal fuels. Evaluation of the project using this price forecast can be seen in Tables 4-2, 4-3, and 4-4. The second forecast was evaluated with a 10 percent rate of return as the economic projections are more conservative as seen in Tables 4-5, 4-6 and 4-7.

The temperature at a depth of $5.7 \mathrm{~km}$ may meet or exceed projections, but the possibility exists that drilling may encounter dry rock or insufficient geothermal fluid to supply the energy demands of the project. In order to justify assuming risks of this nature, the investor must have the opportunity to realize substantial profit from his investment. The following assumptions were made for economic evaluation of the Pine Creek geothermal system:

\section{Reservoir Characteristics and Well Properties}

- 30 year production life of supply well

- Maximum flow rate of geothermal fluid $500 \mathrm{gpm}$ or 249,900 lb/hr

- Temperature of the geothermal fluid at the reservoir well head $=121 \mathrm{C}$ (250F) 
Table 4-2

CASH FLOW BEFORE DEBT SERVICE

CONVENTIONAL FUEL FORECAST \#1

\begin{tabular}{|c|c|c|c|c|c|c|}
\hline \multirow{2}{*}{$\frac{\text { Year }}{1983}$} & \multirow{2}{*}{$\frac{\$ / \text { Gal. Fuel Oil }}{\$ 1.36}$} & $\$ / 10^{6}$ Btu & $\begin{array}{c}\text { Net Savings } \\
\text { Per Year } \\
\end{array}$ & \multirow{2}{*}{$\begin{array}{c}\begin{array}{c}\text { Operations } \\
\text { and } \\
\text { Maintenance }\end{array} \\
-\$ 157,500\end{array}$} & \multicolumn{2}{|c|}{$\begin{array}{c}\text { Net Cash } \\
\text { Flow } \\
\end{array}$} \\
\hline & & $\$ 9.38$ & $\$ 384,580$ & & $\$$ & 227,080 \\
\hline 1984 & $\$ 1.45$ & $\$ 10.00$ & $\$ 410,000$ & $-\$ 157,500$ & $\$$ & 252,500 \\
\hline 1985 & $\$ 1.58$ & $\$ 10.90$ & $\$ \quad 446,900$ & $-\$ 157,500$ & $\$$ & 289,400 \\
\hline 1986 & $\$ 1.72$ & $\$ 11.87$ & $\$ 486,670$ & $-\$ 157,500$ & $\$$ & 329,170 \\
\hline 1987 & $\$ 1.88$ & $\$ 12.97$ & $\$ 531,770$ & $-\$ 157,500$ & $\$$ & 374,270 \\
\hline 1988 & $\$ 2.05$ & $\$ 14.15$ & $\$ 580,150$ & $-\$ 157,500$ & $\$$ & 422,650 \\
\hline 1989 & $\$ 2.23$ & $\$ 15.39$ & $\$ 630,990$ & $-\$ 157,500$ & $\$$ & 473,490 \\
\hline 1990 & $\$ 2.43$ & $\$ 16.77$ & $\$ 687,570$ & $-\$ 157,500$ & $\$$ & 530,070 \\
\hline 1991 & $\$ 2.65$ & $\$ 18.28$ & $\$ 749,480$ & $-\$ 157,500$ & $\$$ & 591,980 \\
\hline 1992 & $\$ 2.89$ & $\$ 19.94$ & $\$ 817,540$ & $-\$ 157,500$ & $\$$ & 660,040 \\
\hline 1993 & $\$ 3.15$ & $\$ 21.74$ & $\$ 891,340$ & $-\$ 157,500$ & $\$$ & 733,840 \\
\hline 1994 & $\$ 3.43$ & $\$ 23.67$ & $\$ 97.0,470$ & $-\$ 157,500$ & $\$$ & 812,970 \\
\hline 1995 & $\$ 3.75$ & $\$ 25.87$ & $\$ 1,060,670$ & $-\$ 157,500$ & $\$$ & 903,170 \\
\hline 1996 & $\$ 4.08$ & $\$ 28.15$ & $\$ 1,154,150$ & $-\$ 157,500$ & $\$$ & 996,650 \\
\hline 1997 & $\$ 4.45$ & $\$ 30.70$ & $\$ 1,258,700$ & $-\$ 157,500$ & $\$ 1$ & $, 101,200$ \\
\hline 1998 & $\$ 4.85$ & $\$ 33.46$ & $\$ 1,371,860$ & $-\$ 157,500$ & $\$ 1$ & $, 214,360$ \\
\hline 1999 & $\$ 5.29$ & $\$ 36.50$ & $\$ 1,496,500$ & $-\$ 157,500$ & $\$ 1$ & $, 339,000$ \\
\hline 2000 & $\$ 5.76$ & $\$ 39.74$ & $\$ 1,629,340$ & $-\$ 157,500$ & $\$ 1$ & $, 471,840$ \\
\hline 2001 & $\$ 6.28$ & $\$ 43.33$ & $\$ 1,776,530$ & $-\$ 157,500$ & $\$ 1$ & $, 619,030$ \\
\hline 2002 & $\$ 6.85$ & $\$ 47.26$ & $\$ 1,937,660$ & $-\$ 157,500$ & $\$ 1$, & $, 780,160$ \\
\hline 2003 & $\$ 7.46$ & $\$ 51.47$ & $\$ 2,110,270$ & $-\$ 157,500$ & $\$ 1$, & $, 952,770$ \\
\hline 2004 & $\$ 8.14$ & $\$ 56.17$ & $\$ 2,302,970$ & $-\$ 157,500$ & $\$ 2$, & $, 145,470$ \\
\hline 2005 & $\$ 8.69$ & $\$ 59.96$ & $\$ 2,458,360$ & $-\$ 157,500$ & $\$ 2$, & $, 300,860$ \\
\hline 2006 & $\$ 9.66$ & $\$ 66.65$ & $\$ 2,732,650$ & $-\$ 157,500$ & $\$ 2$, & $, 575,150$ \\
\hline 2007 & $\$ 10.54$ & $\$ 72.73$ & $\$ 2,981,930$ & $-\$ 157,500$ & $\$ 2$, & $, 824,430$ \\
\hline 2008 & $\$ 11.48$ & $\$ 79.21$ & $\$ 3,247,610$ & $-\$ 157,500$ & $\$ 3$, & $, 089,810$ \\
\hline 2009 & $\$ 12.52$ & $\$ 86.39$ & $\$ 3,541,990$ & $-\$ 157,500$ & $\$ 3$, & $, 384,490$ \\
\hline 2010 & $\$ 13.65$ & $\$ 94.19$ & $\$ 3,861,790$ & $-\$ 157,500$ & $\$ 3$, & $, 704,290$ \\
\hline 2011 & $\$ 14.88$ & $\$ 102.67$ & $\$ 4,209,470$ & $-\$ 157,500$ & $\$ 4$ & $, 051,970$ \\
\hline 2012 & $\$ 16.21$ & $\$ 111.85$ & $\$ 4,585,850$ & $-\$ 157,500$ & $\$ 4$, & $, 428,350$ \\
\hline
\end{tabular}


Table 4-3

AFTER TAX ANALYSIS OF GEOTHERMAL SYSTEM CONVENTIONAL FUEL FORECAST \#1

A

Net Cash Flow

Before Debt

Service

$\underline{\text { Year }}$

and Taxes
B

Cash Flow

For Debt

Repayment
C

Cash Flow For Interest On Debt

$$
\stackrel{D}{(A+B+C)}
$$

Cash Flow

After Debt

Service
$\mathbf{E}$

Depreciation
(Straight Line)

\section{F \\ $(\mathbf{A}+\mathbf{C}+\mathrm{E})$}

$\stackrel{\mathbf{G}}{-(.5 \mathbf{F})}$

Taxable Income
Cash Flow

For Taxes
H

$(D+G)$

After Tax

Net Cash Flow

\begin{tabular}{rrrrr}
\hline 0 & $+2,520,000$ & & \\
1 & 227,080 & $-84,000$ & $-277,200$ \\
2 & 252,500 & $-84,000$ & $-267,960$ \\
3 & 289,400 & $-84,000$ & $-258,720$ \\
4 & 329,170 & $-84,000$ & $-249,480$ \\
5 & 374,270 & $-84,000$ & $-240,240$ \\
6 & 422,650 & $-84,000$ & $-231,000$ \\
7 & 473,490 & $-84,000$ & $-221,760$ \\
8 & 530,070 & $-84,000$ & $-212,520$ \\
9 & 591,980 & $-84,000$ & $-203,280$ \\
10 & 660,040 & $-84,000$ & $-194,040$ \\
11 & 733,840 & $-84,000$ & $-184,800$ \\
12 & 812,970 & $-84,000$ & $-175,560$ \\
13 & 903,170 & $-84,000$ & $-166,320$ \\
14 & 996,650 & $-84,000$ & $-157,080$ \\
15 & $1,101,200$ & $-84,000$ & $-147,840$ \\
16 & $1,214,360$ & $-84,000$ & $-138,600$ \\
17 & $1,339,000$ & $-84,000$ & $-129,360$
\end{tabular}

\begin{tabular}{rr} 
\\
\hline$-134,120$ & $-105,000$ \\
$-99,460$ & $-105,000$ \\
$-53,320$ & $-105,000$ \\
$-13,550$ & $-105,000$ \\
$+50,030$ & $-105,000$ \\
$+107,650$ & $-105,000$ \\
$+167,730$ & $-105,000$ \\
$+233,550$ & $-105,000$ \\
$+304,700$ & $-105,000$ \\
$+382,000$ & $-105,000$ \\
$+465,040$ & $-105,000$ \\
$+553,410$ & $-105,000$ \\
$+652,850$ & $-105,000$ \\
$+755,570$ & $-105,000$ \\
$+869,360$ & $-105,000$ \\
$+991,760$ & $-105,000$ \\
$+1,209,640$ & $-105,000$
\end{tabular}

(1)

$\begin{array}{rrr} & & -630,000 \\ -155,120 & +77,560 & -56,560 \\ -120,460 & +60,230 & -39,230 \\ -74,320 & +37,160 & -16,160 \\ -25,310 & +12,655 & 895 \\ 29,030 & -14,515 & 35,515 \\ 86,650 & -43,325 & 64,325 \\ 146,730 & -73,365 & 94,365 \\ 212,550 & -106,275 & 127,275 \\ 283,700 & -141,850 & 162,850 \\ 361,000 & -180,500 & 201,500 \\ 444,040 & -222,020 & 243,020 \\ 532,410 & -266,205 & 287,205 \\ 631,850 & -315,925 & 336,925 \\ 734,570 & -367,285 & 388,285 \\ 848,360 & -424,180 & 445,180 \\ 979,760 & -485,380 & 506,380 \\ 1,188,640 & -594,320 & 615,320\end{array}$


Table 4-3 (Continued)

\begin{tabular}{|c|c|c|c|c|c|c|c|c|}
\hline Year & $\begin{array}{c}\text { A } \\
\text { Net Cash Flow } \\
\text { Before Debt } \\
\text { Service } \\
\text { and Taxes } \\
\end{array}$ & $\begin{array}{c}\text { Cash Flow } \\
\text { For Debt } \\
\text { Repayment }\end{array}$ & $\begin{array}{c}\text { Cash Flow For } \\
\text { Interest } \\
\text { On Debt } \\
\end{array}$ & $\begin{array}{c}\mathrm{D} \\
(\mathrm{A}+\mathrm{B}+\mathrm{C}) \\
\\
\text { Cash Flow } \\
\text { After Debt } \\
\text { Service } \\
\end{array}$ & $\begin{array}{c}\text { Depreciation } \\
\text { (Straight } \\
\text { Line) } \\
\end{array}$ & $\underset{(A+C+E)}{F}$ & $\begin{array}{l}\text { Cash Flow } \\
\text { For Taxes }\end{array}$ & $\begin{array}{c}\mathrm{H} \\
(\mathrm{D}+\mathrm{G}) \\
\\
\text { After Tax } \\
\text { Net Cash } \\
\text { Flow } \\
\end{array}$ \\
\hline 18 & $1,471,840$ & $-84,000$ & $-120,120$ & $+1,267,720$ & $-105,000$ & $1,246,720$ & $-623,360$ & 644,360 \\
\hline 19 & $1,619,030$ & $-84,000$ & $-110,880$ & $+1,424,150$ & $-105,000$ & $1,403,150$ & $-701,575$ & 722,575 \\
\hline 20 & $1,780,160$ & $-84,000$ & 101,640 & $+1,594,520$ & $-105,000$ & $1,573,520$ & $-786,760$ & 807,760 \\
\hline 21 & $1,952,770$ & $-84,000$ & $-92,400$ & $+1,776,370$ & $-105,000$ & $1,755,370$ & $-877,685$ & 898,685 \\
\hline 22 & $2,145,470$ & $-84,000$ & $-83,160$ & $+1,978,310$ & $-105,000$ & $1,957,310$ & $-978,655$ & 999,655 \\
\hline 23. & $2,300,860$ & $-84,000$ & $-73,920$ & $+2,142,940$ & $-105,000$ & $2,121,940$ & $-1,060,970$ & $1,081,970$ \\
\hline 24 & $2,575,150$ & $-84,000$ & $-64,680$ & $+2,426,470$ & $-105,000$ & $2,405,470$ & $-1,202,735$ & $1,223,735$ \\
\hline 25 & $2,824,430$ & $-84,000$ & $-55,440$ & $+2,684,990$ & $-105,000$ & $2,663,900$ & $-1,331,995$ & $1,352,995$ \\
\hline 26 & $3,089,810$ & $-84,000$ & $-46,200$ & $+2,999,610$ & $-105,000$ & $2,978,610$ & $-1,489,305$ & $1,459,315$ \\
\hline 27 & $3,384,490$ & $-84,000$ & $-36,960$ & $3,261,530$ & $-105,000$ & $3,242,530$ & $-1,621,265$ & $1,642,265$ \\
\hline 28 & $3,704,290$ & $-84,000$ & $-27,720$ & $3,592,570$ & $-105,000$ & $3,571,570$ & $-1,785,785$ & 1,$806 ; 785$ \\
\hline 29 & $4,051,070$ & $-84,000$ & $-18,480$ & $3,949,490$ & $-105,000$ & $3,928,490$ & $-1 ; 964,245$ & $1,985,245$ \\
\hline 30 & $4,428,350$ & $-84,000$ & $-9,240$ & $4,335,110$ & $-105,000$ & $4,274,110$ & $-2,137,055$ & $2,198,055$ \\
\hline
\end{tabular}


Table 4-4

PRESENT WORTH ANALYSIS

CONVENTIONAL FUEL FORECAST \#1

Year

0

1

2

3

4

5

6

7

8

9

10

11

12

13

14

15

16

17

18

19

20

21

22

23

24

25

26

27

28

29

30
Cash Flow

After Taxes

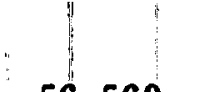

$-56,560$

$-39,230$

$-16,160$

$+895$

35,515

64,325

94,365

127,275

162,850

201,500

243,020

287,205

336,925

388,285

445,180

506,380

615,320

644,360

722,575

807,760

898,685

999,655

$1,081,970$

$1,223,735$

1,352, 995

$1,459,315$

$1,642,265$

$1,806,785$

$1,985,245$

$2,198,055$
Present Worth

Factor \& 20\%

0.8333

0.6944

0.5787

0.4823

0.4019

0.3349

0.2791

0.2326

0.1938

0.1615

0.1346

0.1122

0.0935

0.0779

0.0649

0.0541

0.0451

0.0376

0.0313

0.0261

0.0217

0.0181

0.0151

0.0126

0.0105

0.0087

0.0073

0.0061

0.0051

0.0042
Present Worth (\$)

$-630,000$

$-47,131$

$-27,241$

$-9,352$

432

14,273

21,542

26,337

29,604

31,560

32,542

32,710

32,224

31,502

30,247

28,892

27,395

27,751

24,228

22,617

21,083

19,501

18,094

16,338

15,419

14,206

12,696

11,988

11,021

10,124

$\underline{9,232}$ 
Table 4-5

CASH FLOW BEFORE DEBT SERVICE

CONVENTIONAL FUEL FORECAST \#2

\begin{tabular}{|c|c|c|c|c|c|c|c|}
\hline \multirow{2}{*}{$\begin{array}{l}\text { Year } \\
1983\end{array}$} & \multirow{2}{*}{$\begin{array}{c}\$ / \text { Gal. Fuel Oil } \\
\$ 1.06\end{array}$} & $\$ / 10^{6} \mathrm{Btu}$ & \multicolumn{2}{|c|}{$\begin{array}{c}\text { Net Savings } \\
\text { Per Year } \\
\end{array}$} & \multirow{2}{*}{$\begin{array}{c}\begin{array}{c}\text { Operations } \\
\text { and } \\
\text { Maintenance }\end{array} \\
-\$ 157,500\end{array}$} & \multicolumn{2}{|c|}{$\begin{array}{c}\text { Net Cash } \\
\text { Flow } \\
\end{array}$} \\
\hline & & $\$ 7.31$ & $\$$ & 299,710 & & $\$$ & 142,210 \\
\hline 1984 & $\$ 1.14$ & $\$ 7.87$ & $\$$ & 322,670 & $-\$ 157,500$ & $\$$ & 165.170 \\
\hline 1985 & $\$ 1.22$ & $\$ 8.42$ & $\$$ & 345,220 & $-\$ 157,500$ & $\$$ & 187,720 \\
\hline 1986 & $\$ 1.30$ & $\$ 8.97$ & $\$$ & 367,770 & $-\$ 157,500$ & $\$$ & 210,270 \\
\hline 1987 & $\$ 1.36$ & $\$ 9.38$ & $\$$ & 384,580 & $-\$ 157,500$ & $\$$ & 227,080 \\
\hline 1988 & $\$ 1.41$ & $\$ 9.73$ & $\$$ & 398,930 & $-\$ 157,500$ & $\$$ & 241,430 \\
\hline 1989 & $\$ 1.47$ & $\$ 10.14$ & $\$$ & 415,740 & $-\$ 157,500$ & $\$$ & 258,240 \\
\hline 1990 & $\$ 1.53$ & $\$ 10.56$ & $\$$ & 432,960 & $-\$ 157,500$ & $\$$ & 275,460 \\
\hline 1991 & $\$ 1.59$ & $\$ 10.97$ & $\$$ & 449,770 & $-\$ 157,500$ & $\$$ & 292,270 \\
\hline 1992 & $\$ 1.65$ & $\$ 11.39$ & $\$$ & 466,990 & $-\$ 157,500$ & $\$$ & 309,490 \\
\hline 1993 & $\$ 1.72$ & $\$ 11.87$ & $\$$ & 486,670 & $-\$ 157,500$ & $\$$ & 329,170 \\
\hline 1994 & $\$ 1.78$ & $\$ 12.28$ & $\$$ & 503,480 & $-\$ 157,500$ & $\$$ & 345,980 \\
\hline 1995 & $\$ 1.86$ & $\$ 12.83$ & $\$$ & 526,030 & $-\$ 157,500$ & $\$$ & 368,530 \\
\hline 1996 & $\$ 1.93$ & $\$ 13.32$ & $\$$ & 546,120 & $-\$ 157,500$ & $\$$ & $.388,620$ \\
\hline 1997 & $\$ 2.01$ & $\$ 13.87$ & $\$$ & 568,670 & $-\$ 157,500$ & $\$$ & $.411,170$ \\
\hline 1998 & $\$ 2.09$ & $\$ 14.42$ & $\$$ & 591,220 & $-\$ 157,500$ & $\$$ & 433,720 \\
\hline 1999 & $\$ 2.17$ & $\$ 14.97$ & $\$$ & 613,770 & $-\$ 157,500$ & $\$$ & 456,270 \\
\hline 2000 & $\$ 2.26$ & $\$ 15.59$ & $\$$ & 639,190 & $-\$ 157,500$ & $\$$ & 481,690 \\
\hline 2001 & $\$ 2.35$ & $\$ 16.21$ & $\$$ & 664,610 & $-\$ 157,500$ & $\$$ & 507,110 \\
\hline 2002 & $\$ 2.44$ & $\$ 16.84$ & $\$$ & 690,440 & $-\$ 157,500$ & $\$$ & 532,940 \\
\hline 2003 & $\$ 2.54$ & $\$ 17.53$ & $\$$ & 718,730 & $-\$ 157,500$ & $\$$ & 561,230 \\
\hline 2004 & $\$ 2.64$ & $\$ 18.22$ & $\$$ & 747,020 & $-\$ 157,500$ & $\$$ & 589,520 \\
\hline 2005 & $\$ 2.75$ & $\$ 18.96$ & $\$$ & 777,360 & $-\$ 157,500$ & $\$$ & 619,860 \\
\hline 2006 & $\$ 2.86$ & $\$ 19.73$ & $\$$ & 808,930 & $-\$ 157,500$ & $\$$ & 651,430 \\
\hline 2007 & $\$ 2.97$ & $\$ 20.49$ & $\$$ & 840,090 & $-\$ 157,500$ & $\$$ & 682,590 \\
\hline 2008 & $\$ 3.09$ & $\$ 21.32$ & $\$$ & 874,120 & $-\$ 157,500$ & $\$$ & 716,620 \\
\hline 2009 & $\$ 3.21$ & $\$ 22.15$ & $\$$ & 908,150 & $-\$ 157,500$ & $\$$ & 750,650 \\
\hline 2010 & $\$ 3.34$ & $\$ 23.05$ & $\$$ & 945,050 & $-\$ 157,500$ & $\$$ & 787,550 \\
\hline 2011 & $\$ 3.48$ & $\$ 24.01$ & $\$$ & 984,410 & $-\$ 157,500$ & $\$$ & 826,910 \\
\hline 2012 & $\$ 3.61$ & $\$ 24.91$ & & 021,310 & $-\$ 157,500$ & $\$$ & 863,810 \\
\hline
\end{tabular}


Table 4-6

AFTER TAX ANALYSIS OF GEOTHERMAL SYSTEM CONVENTIONAL FUEL FORECAST \#2

A

Net Cash Flow Before Debt

Service

Year. and Taxes
B

Cash Flow

For Debt Repayment
$\mathbf{C}$

Cash Flow For Interest On Debt
$\underset{(A+B+C)}{D}$

Cash Flow

After Debt

Service
E

Depreciation
(Straight
Line)
$\underset{(A+C+E)}{F}$

Taxable Income
$G$
$-(.5 F)$

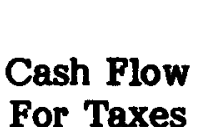

$\underset{(D+G)}{H}$

\section{After Tax}

Net Cash For Taxes Flow

$\begin{array}{rrrrr}0 & =3,150,000 & & \\ 1 & +2,520,000 & & \\ 2 & 142,210 & -84,000 & -277,200 \\ 3 & 165,170 & -84,000 & -267,960 \\ \text { \& } & 187,720 & -84,000 & -258,720 \\ 4 & 210,270 & -84,000 & -249,480 \\ 5 & 227,080 & -84,000 & -240,240 \\ 6 & 241,430 & -84,000 & -231,000 \\ 7 & 258,240 & -84,000 & -221,760 \\ 8 & 275,460 & -84,000 & -212,520 \\ 9 & 292,270 & -84,000 & -203,280 \\ 10 & 309,490 & -84,000 & -194,040 \\ 11 & 329,170 & -84,000 & -184,800 \\ 12 & 345,980 & -84,000 & -175,560 \\ 13 & 368,530 & -84,000 & -166,320 \\ 14 & 388,620 & -84,000 & -157,080 \\ 15 & 411,170 & -84,000 & -147,840 \\ 16 & 433,720 & -84,000 & -138,600 \\ 17 & 456,270 & -84,000 & -129,360\end{array}$

(1)

$\begin{array}{rr}-218,990 & -105,000 \\ -186,790 & -105,000 \\ -155,000 & -105,000 \\ -123,210 & -105,000 \\ -97,160 & -105,000 \\ -73,570 & -105,000 \\ -47,520 & -105,000 \\ -21,060 & -105,000 \\ -4,990 & -105,000 \\ +31,450 & -105,000 \\ +60,370 & -105,000 \\ +86,420 & -105,000 \\ +118,210 & -105,000 \\ +147,540 & -105,000 \\ +179,330 & -105,000 \\ +211,120 & -105,000 \\ +242,910 & -105,000\end{array}$

$-239,990$
$-207,790$
$-176,000$
$-144,210$
$-118,160$
$-94,570$
$-68,520$
$-42,060$
$-16,010$
$+10,450$
$+39,370$
$+65,420$
$+97,210$
$+126,540$
$+158,330$
$+190,120$
$+221,910$

$+119,995$.

$-630,000$

$+103,895$

$-98,995$

$+88,000$

$-67,000$

$+72,105$

$-51,105$

$+59,080$

$-38,080$

$+47,285$

$-26,285$

$+34,260$

$-13,260$

$+21,030$

$-30$

$+12,995$

$+26,225$

$+40,685$

$+53,710$

$+69,605$

$+84,270$

$+100,165$

$+116,060$

$+131,955$ 
Table 4-6 (Continued)

\begin{tabular}{|c|c|c|c|c|c|c|c|c|}
\hline Year & $\begin{array}{c}\text { A } \\
\text { Net Cash Flow } \\
\text { Before Debt } \\
\text { Service } \\
\text { and Taxes } \\
\end{array}$ & $\begin{array}{c}\text { Cash Flow } \\
\text { For Debt } \\
\text { Repayment } \\
\end{array}$ & $\begin{array}{c}\text { Cash Flow For } \\
\text { Interest } \\
\text { On Debt } \\
\end{array}$ & $\begin{array}{c}\text { D } \\
(\mathrm{A}+\mathrm{B}+\mathrm{C}) \\
\\
\text { Cash Flow } \\
\text { After Debt } \\
\text { Service } \\
\end{array}$ & $\begin{array}{c}\text { Depreciation } \\
\text { (Straight } \\
\text { Line) } \\
\end{array}$ & $\stackrel{F}{(A+C+E)}$ & $\begin{array}{l}\text { Cash Flow } \\
\text { For Taxes } \\
\end{array}$ & $\begin{array}{c}\mathrm{H} \\
(\mathrm{D}+\mathrm{G}) \\
\\
\text { After Tax } \\
\text { Net Cash } \\
\text { Flow } \\
\end{array}$ \\
\hline 18 & 481,690 & $-84,000$ & $-120,120$ & $+277,570$ & $-105,000$ & $+256,570$ & $-128,285$ & $+149,285$ \\
\hline 19 & 507,110 & $-84,000$ & $-110,880$ & $+312,230$ & $-105,000$ & $+291,230$ & $-145,615$ & $+166,615$ \\
\hline 20 & 532,940 & $-84,000$ & $-101,640$ & $+347,300$ & $-105,000$ & $+326,300$ & $-163,150$ & $+184,150$ \\
\hline 21 & 561,230 & $-84,000$ & $-92,400$ & $+384,830$ & $-105,000$ & $+363,830$ & $-181,915$ & $+202,915$ \\
\hline 22 & 589,520 & $-84,000$ & $-83,160$ & $-422,360$ & $-105,000$ & $+401,360$ & $-200,680$ & $+221,680$ \\
\hline 23 & 619,860 & $-84,000$ & $-73,920$ & $+461,940$ & $-105,000$ & $+440,940$ & $-220,470$ & $+241,470$ \\
\hline 24 & 651,430 & $-84,000$ & $-64,680$ & $+502,750$ & $-105,000$ & $+481,750$ & $-240 ; 875$ & $+261,875$ \\
\hline 25 & 682,590 & $-84,000$ & $-55,440$ & $+543,150$ & $-105,000$ & $+522,150$ & $-261,075$ & $+282,075$ \\
\hline 26 & 716,620 & $-84,000$ & $-46,200$ & $-586,420$ & $-105,000$ & $+565,420$ & $-282,710$ & $+303,710$ \\
\hline 27 & 750,650 & $-84,000$ & $-36,960$ & $+629,690$ & $-105,000$ & $+608,690$ & $-304,345$ & $+325,345$ \\
\hline 28 & 787,550 & $-84,000$ & $-27,720$ & $+675,830$ & $-105,000$ & $+654,830$ & $-327,415$ & $+348,415$ \\
\hline 29 & 826,910 & $-84,000$ & $-18,480$ & $+724,430$ & $-105,000$ & $+703,430$ & $-351,715$ & $+372,715$ \\
\hline 30 & 863,810 & $-84,000$ & $-9,240$ & $+770,570$ & $-105,000$ & $+749,570$ & $-374,785$ & $+395,785$ \\
\hline
\end{tabular}


Table 4-7

PRESENT WORTH ANALYSIS

CONVENTIONAL FUEL FORECAST \#2

Cash Flow

After Taxes

$-630,000$

98,995

$-82,895$

$-67,000$

$-51,105$

$-38,080$

$-26,285$

13,260

$-30$

$+12,995$

$+26,225$

$+40,685$

$+53,710$

$+69,605$

$+84,270$

$+100,165$

$+116,060$

$+131,955$

$+149,285$

$+166,615$

$+184,150$

$+202,915$

$+221,680$

$+241,470$

$+261,875$

+282,075

$+303,710$

$+325,345$

$+348,415$

$+372,715$

$+395,785$
Present Worth

Factor @ 10\%

0.9091

0.8264

0.7513

0.6830

0.6209

0.5645

0.5132

0.4665

0.4241

0.3855

0.3505

0.3186

0.2897

0.2633

0.2394

0.2176

0.1978

0.1799

0.1635

0.1486

0.1351

0.1228

0.1117

0.1015

0.0923

0.0839

0.0763

0.0693

0.0630

0.0573
Present Worth (\$)

$-630,000$

$-89,996$

$-68,504$

$-50,337$

$-34,905$

$-23,644$

$-14,838$

$-6,805$

$-14$

$+5,511$

$+10,110$

$+14,260$

$+17,112$

$+20,165$

$+22,188$

$+23,980$

$+25,255$

$+26,100$

$+26,856$

$+27,242$

$+27,365$

$+27,414$

$+27,222$

$+28,252$

$+26,580$

$+26,036$

$+25,481$

$+24,824$

$+24,145$

$+23,481$

$+22,678$ 


\section{REFERENCES}

Energy Supply and Demand in the Short Term: 1979 and 1980, June 1979, Energy Information Administration, Washington, DC, DOE/EIA-0184/4.

Energy Tax Act of 1978, Public Law Number 95-618.

Engen, I.A., February 1978, Residential Space Heating Cost: Geothermal vs. Conventional Systems, under DOE Contract EY-76-C-07-1570.

Grant, Ireson, Leavenworth, 1976, Engineering Economy.

Kappelman, Ellis E., Stephen M., Lee, Ruth F. Klever and D.R. Cruise, April 1977, Fuel Cost Escalation Study Naval Weapons Center, China Lake, CA. Contract AD/A040209.

Reynolds, Smith and Hills, 1976, Life Cycle Costing Emphasizing Energy Conservation, Guidelines for Investment Analysis, prepared for U.S. Department of Commerce under $\mathrm{E}(49-1)-3850$.

Richardson, 1979, Richardson Rapid Construction Cost Estimating System. Volumes 1, 3 and 4. 



\section{SECTION 5}

\section{THE GEOTHERMAL RESOURCE}

\section{$5.1 \quad$ INTRODUCTION}

\subsubsection{Purpose and Scope}

The purpose of this study was to investigate the potential availability of geothermal energy resources for economic utilization at Union Carbide - Metals Division's Pine Creek Tungsten Mine and Mill. This report is a preliminary answer to the question of whether a low temperature geothermal resource exists at the Pine Creek Mine based on surface observations alone to decide whether drilling should be recommended.

The Pine Creek Mine is located about 20 kilometers $(12.4 \mathrm{mi})$ south of the Mono-Long Valley Known Geothermal Resource Area in an area designated as a prospective geothermal resource area on the Map of Geothermal Energy Resources of the Western United States prepared by the National Geophysical and Solar Terrestrial Data Center for the National Oceanographic and Atmospheric Administration (1977). The potential for geothermal resources occuring at the mine was encouraged by the presence of a relatively warm water spring inside the mine. The area in which the mine occurs was not classified as a potential geothermal resource area in a later edition of the aforementioned map published with U.S. Geological Survey Circular 790 (Muffler, 1979).

Chemical analyses of groundwater from the vicinity of the Pine Creek Mine were obtained from the available literature and from the files of public agencies. These data and the locations of springs shown on the U.S. Geological Survey Mount Tom and Casa Diablo Mountain 15 minute quadrangles were used to select springs where water samples could be obtained for chemical analysis. Wells were selected on the basis of location and accessibility for sampling.

Water samples were sent to various laboratories for analysis which included dissolved chemical species and oxygen and hydrogen isotopes. Interpretations are made on the basis of the chemical character and quality of the groundwaters as they affect the suitability of individual samples for use in various published geochemical geothermometers. Deuterium and oxygen-18 content were determined on select samples to check for possible heating effects, and tritium levels were determined to estimate relative ages of the various groundwater types.

\subsubsection{Spring and Well Numbering System}

Each spring and well encountered during the investigation was assigned a letter in order of sample collection. The locations of the wells and springs were identified by numbers according to the California State Well Numbering System. In this system wells and springs are assigned numbers which are referenced by the U.S. Public Land Survey System; a rectangular system for the subdivision of land. For example, as shown in Figure 5-1, in the number $06 \mathrm{~S} / 31 \mathrm{E}-5 \mathrm{H} 01$, the part of the number preceding the 


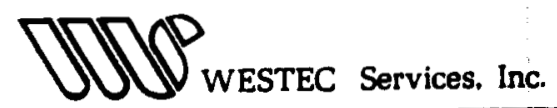

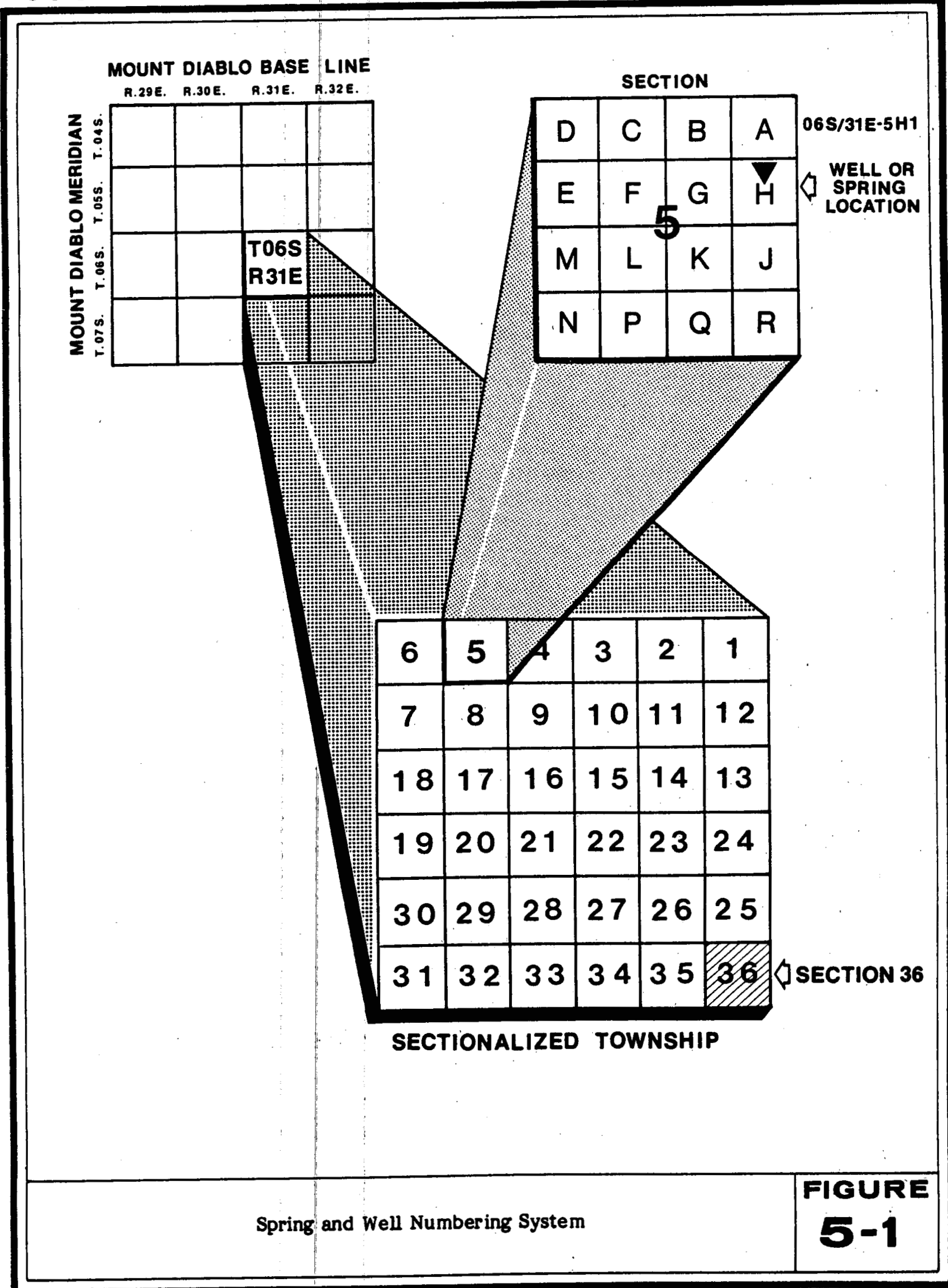


virgule indicates the township (Township 06 South); the part between the virgule and the dash indicates the range (Range 31 East); the number between the dash and the letter indicates the section (Section 05); and the letter indicates the 16.2 hectare (40-acre) tract within the section.

Within the 16.2 hectare (40-acre) tract wells are numbered serially, as indicated by the final digit. Thus, well $06 \mathrm{~S} / 31 \mathrm{E}-5 \mathrm{H} 01$ is the first well to be listed in the SEd t:NEt :Sec. 5, T6S, R31E, Mount Diablo baseline and meridian. Springs are numbered similarly except that an $S$ is placed between the 16.2 hectare $(40$-acre) tract letter and the final digit, as shown in the following spring number: 07S/30E-9QS01.

\subsection{GEOLOGIC SETTING}

\subsubsection{Location and General Features}

Pine Creek is in east-central California, in northern Inyo County, about 27 kilometers $(16.8 \mathrm{mi}$ ) west of Bishop (Figure 5-2). Elevation at the main adit of the mine is approximately 2469 meters $(8100 \mathrm{ft})$ above mean sea level. The mine is high on the eastern slope of the Sierra Nevada Mountains near the head of the alluvium filled glaciated canyon of Pine Creek which opens outward about 11 kilometers $(6.8 \mathrm{mi})$ northeast of the mine into Round Valley, a northwestern extension of the Owens Valley. The last three kilometers $(1.9 \mathrm{mi})$ of the canyon are formed by lateral moraines which extend outward from the shear granitic walls of the canyon.

From the myriad of lithologic units recognized in the area by Bateman (1965) four groupings of units are considered to be relevant to this investigation. The pertinent units are all a grouping of granitic, metamorphic and other basement rocks into pre-Quaternary basement rocks which form the Wheeler Crest, Mount Tom, the Tungsten Hills, and other topographic high areas in the Sierra Nevada portion of the study area. Individual lithologic units in the basement rocks are retained for certain springs and when discussing a model of the geothermal resource.

Glacial and alluvial units are grouped into Quaternary sediments and make up the bulk of the central portion of the study area in Round Valley as well as scattered other portions of the study area. Two volcanic units are significant to this study: the Pleistocene Bishop Tuff in the northeastern quarter of the study area and late Tertiary or early Pleistocene basalt in the Tunsgsten Hills. The distribution of these units in the vicinity of the Pine Creek Mine is shown in Plate 1. The sources of the geologic data shown on Plate 1 are identified on Figure 5-3.

\subsubsection{Geophysical Measurements in the Vicinity of the Pine Creek Mine}

Pakiser, et al. (1964) and Pakiser and Kane (1965) presented a gravity map of the northern Owens Valley area which included Round Valley. A gravity low was reported for the volcanic tableland east of Round Valley which was shown to diminish westward toward Round Valley. The authors interpreted the data to mean that the Bishop Tuff extended into the alluvium of Round Valley at shallow depth.

Several heat flow measurements have been attempted inside the Pine Creek Mine by the U.S. Geological Survey but were unsuccessful (Posner, 1979). A heat flow 


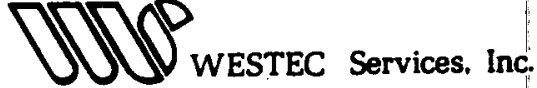

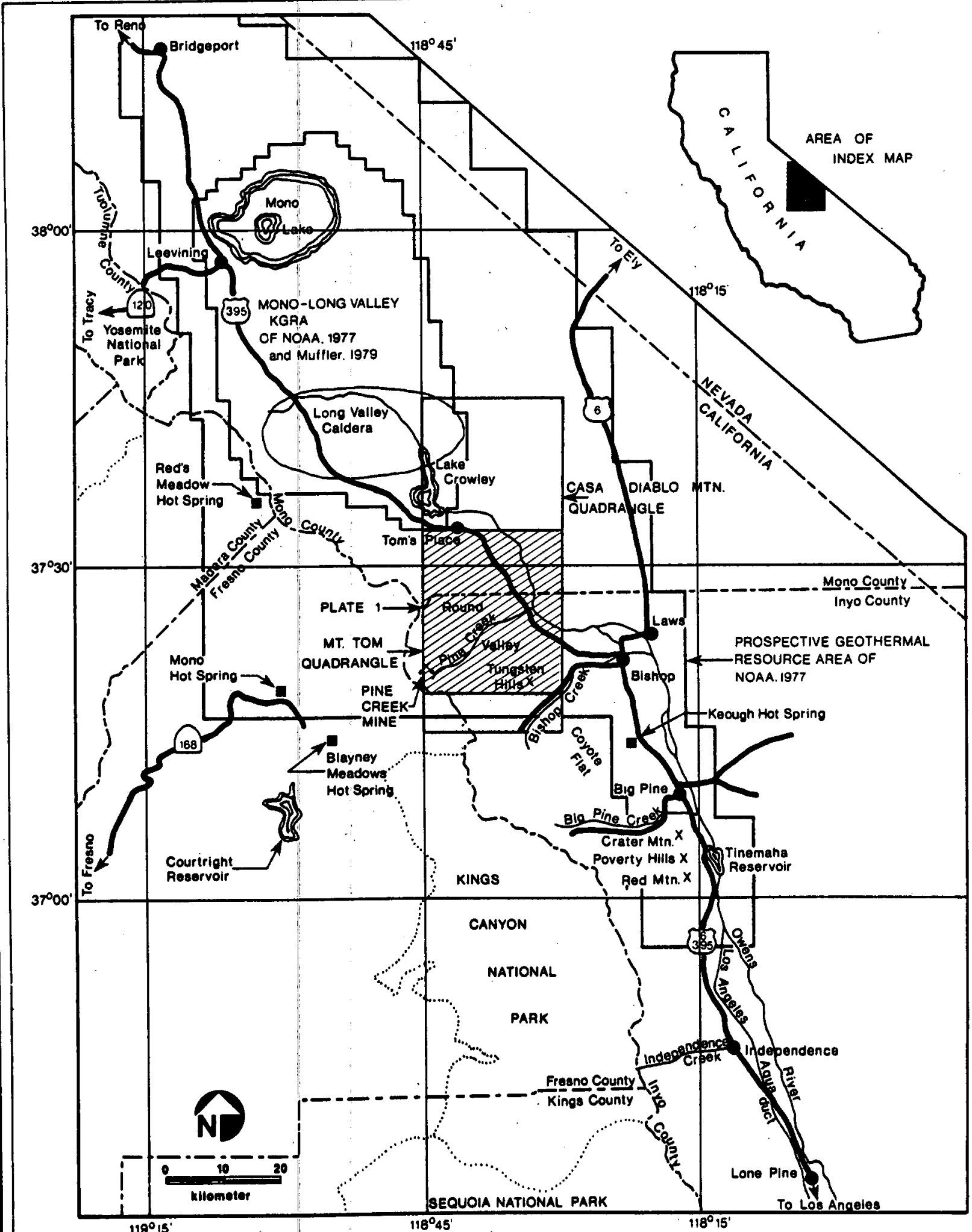

Map showing the location of the Pine Creek Mine Area.

FIGURE 
measurement about 35 kilometers $(21.7 \mathrm{mi}$ ) southwest of the mine (drillhole $\mathrm{HC}$, near Helms Creek at Courtright Reservoir) was reported by Lachenbruch (1968) as 1.30 Heat

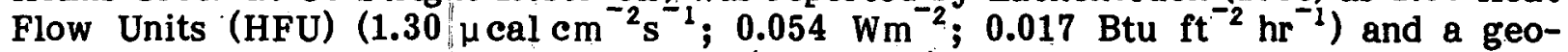
thermal gradient of $17.2 \mathrm{C}$ per kilometer $(49.8 \mathrm{~F} / \mathrm{mi})$ of depth was reported. Two heat flow measurements of $.93 \mathrm{HFU}\left(.93 \mu \mathrm{cal} \mathrm{cm}^{-2} \mathrm{sec}^{-1} ; 0.039 \mathrm{Wm}^{-2} ; 0.012 \mathrm{Btu} \mathrm{ft}^{-2} \mathrm{hr}^{-1}\right)$ and $1.27 \mathrm{HFU}\left(1.27 \mu \mathrm{cal} \mathrm{cm}^{-2} \mathrm{sec}^{-1} ; .053 \mathrm{Wm}^{-2} ; .017 \mathrm{Btu} \mathrm{ft}^{-2} \mathrm{hr}^{-1}\right)$ were reported by Lachenbruch, et al., (1976) for the east and west sides of the Tungsten Hills, respectively, which are about 10 kilometers $(6.2 \mathrm{mi})$ east of the mine. These heat flow measurements were reported to indicate a geothermal gradient of $15.1 \mathrm{C}$ per kilometer $(43.7 \mathrm{~F} / \mathrm{mi})$ of depth. Each of these geothermal gradients is lower than the typical global value of $25 \mathrm{C}$ per kilometer $(72.4 \mathrm{~F} / \mathrm{mi}$ ) (Gouguel, 1976).

A rock temperature measurement has been made in a drillhole in the Brownstone adit of the Pine Creek Mine and showed a temperature of about 14C (57.2F) (Posner, 1979) which is significantly above the average annual temperature of $4 \mathrm{C}$ (39.2F) (Brewer, 1979).

' Microearthquakes have been monitored in the vicinity of the Long Valley Caldera and the northern Owens Valley and the data includes the Pine Creek Mine area (Pitt and Steeples, 1968; Steeples and Pitt, 1976). Several microearthquakes occurred beneath Round Valley and a few events were reported beneath the Pine Creek Mine (Pitt and Steeples, 1968), at depths of 6.5 to 17.5 kilometers (4.04 to 10.9 miles).

No further geophysical information is available from the vicinity of the Pine Creek Mine (Posner, 1979) and none was attempted during this investigation.

\subsubsection{Springs and Wells in Relation to Geology}

Springs were selected for investigation on the basis of the type of rock from which they discharged and on the basis of the type of springs, as described below. The rock type from which water samples were collected is summarized in Table 5-1. Springs used in this study are divided into two main categories: bedrock springs discharging directly from fractures in the hard crystalline rock (Fracture Springs of Bryan, 1919) (Springs B, C, and D) and alluvial springs whose waters arise through Quaternary sediments. Alluvium in the Pine Creek Mine area is generally derived from mixed granitic and metamorphic sources. Alluvial springs are further divided into fault controlled (Fault Dam Springs of Bryan, 1919) (Springs A, G, K, and L) and springs presumably controlled by the stratigraphy of the alluvium (Gravity Springs of Bryan, 1919) (Springs E, J, and P).

Water samples were collected from six wells in Round Valley downstream from the Pine Creek Mine. The nature of the strata inferred to have been penetrated by these wells is listed in Table 5-1 based on geologic maps and sections presented by Bateman (1965). A lithologic log was available from only one of these wells (Well F) and is shown in Figure 5-4.

The lithologic log and well completion history of the Rovana Water Supply Well (Well F) was provided by Mr. Ken Rwoan (1979) of Union Carbide Corporation and allows for an intuitive understanding of the groundwater system in Round Valley. This well was drilled to a depth of 125 meters $(410.1 \mathrm{ft}$ ) in 1964 . Water cascaded down the 
Table 5-1

LOCATION, NAME, AND GEOLOGICAL RELATIONS OF SPRINGS AND WELLS UTILIZED FOR THIS INVESTIGATION

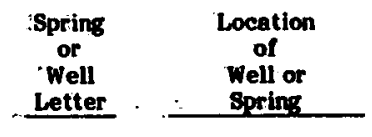

A

.06S/31E - 31 RS1

B $\quad 07 \mathrm{~S} / 30 \mathrm{E}-8 \mathrm{CS} 1$

C

D

B

F

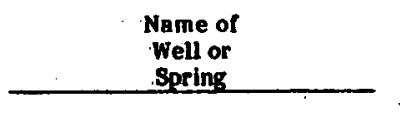

"Bescon" Spring

Easy Going Warm Spring

Easy Going Cold Spring

Gable Creek Spring

Mill Spring

Rovana Water Supply Well

Rovana Water Supply.Spring

Round Valley.school Well

ccc well

Mile Post:333.5 Spring

Ainsley Spring

Wells Meadow, main.spring

C-Bar-O Ranch Well (40 acres)

North Schober Well

South Schober Well

Buttermillk Spring

Keough Hot Springs

Pine Creek Surface Flow

\section{Geology of Spring or Well}

Sierran frontal spring. Discharges along short fault in olluvial fan about $0.8 \mathrm{~km}$ from base of mountain. Alluvium derived from granitic and metamorphic rock.

Discharges from fracture through drill holes from :marble in underground workings. This is one of several drillholes which discharge warm water in this portion of the mine. Location $524 \mathrm{~m}$ from portal.

Discharges from fractures in marble in underground workings. Location $2.4 \mathrm{~km}$ from portal.

Discharges from fractures in granitic rock beneath shallow colluvium on steep west-facing slope of Gable Creek Canyon.

Discharges from granitic rock derived alluvium on thoor of Pine Creek Canyon below the Pine Creek Mine mill.

125 Meter deep well penetrating alluvium, alluvial fan deposits, and Blshop Tuff (Bigure 5-4).

Discharges from Tioga stage moraine of Pine Creek at contact with valley tloor alluvium.

Well, depth uncertain, penetrating alluvium, alluvial fan deposits and possibly Bishop Tuff."

61 meter deep well penetrating alluvial fan deposits and possibly other deposits. ${ }^{2}$

Discharges from beneath ridge crest in Tioga moraine of Rock Creek Canyon.

Sierran frontal spring. Discharges from beneath granitic talus at contact with alluvial ran.

Sierran frontal spring. Discharges along short fault in granitic alluvium parallel with sierran frontal fault and approximately 200 meters from base of mountain.

25 meter deep well penetrating alluvial fan deposits of granitic composition.

38 meter deep well penetrating stallow (<3m) alluvium and Bishop Tuff.

$40 \pm$ meter deep well penotratios allurvium and poedbly Bhonop Tuff.

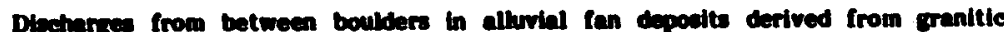
termene.

Discharge from fractures in granitic rocks through cement lined basins.

' Well log was not available for examination. 
WESTEC Services. Inc.

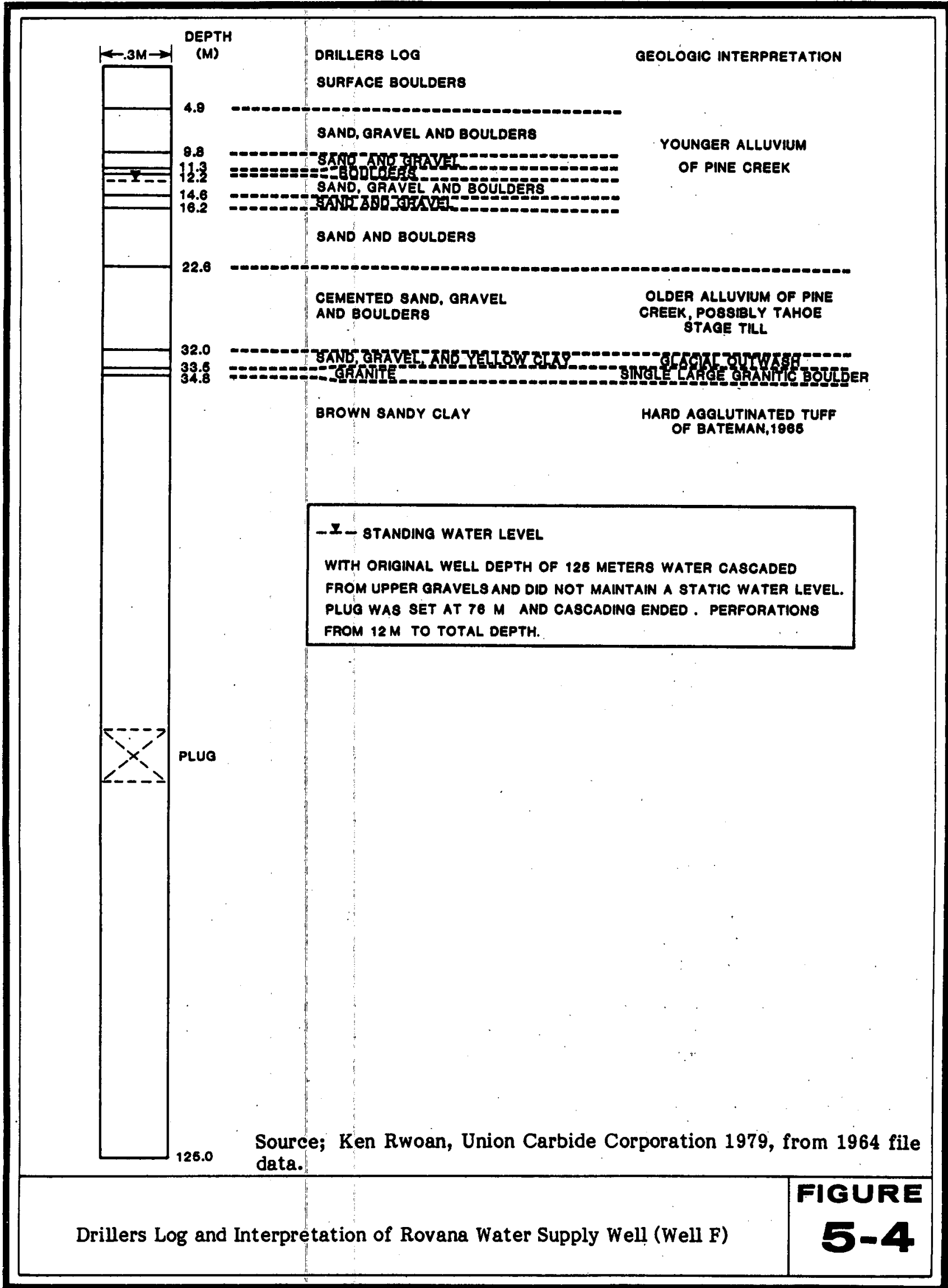


wellbore and failed to maintain a water level sufficiently high to allow pumping from a pump set at about 45 meters $(147.6 \mathrm{ft}$ ). An airlift system was capable of sustaining 132 liters per minute $\left(34.87 \mathrm{gal} \mathrm{min}^{-1}\right)$ from near total depth. The wellbore was later plugged at about 76 meters $(249.4 \mathrm{ft})$ depth which allowed standing water level to rise to 12.8 meters $(42.0 \mathrm{ft})$ below the surface and allow sustained pumping of about 208 liters per minute (54.95 gal $\left.\mathrm{min}^{-1}\right)$. The cascading water in this well suggests a two tier groundwater system separated by an unsaturated interval in the Bishop Tuff for at least the western portion of Round Valley. Sulfate and tritium concentrations discussed later suggest a fairly rapid rate of groundwater movement through the upper aquifer.

\subsection{HYDROGEOCHEMISTRY}

\subsubsection{Field and Laboratory Analysis}

The groundwater of the vicinity of the Pine Creek Mine contains a variety of chemical species in solution at low concentrations. Knowledge of the chemical types and concentrations is useful in interpreting patterns of groundwater movement, source of the water, and for screening samples for further interpretations.

As part of this study, samples for chemical and isotope analysis were collected in December 1979 from 17 springs and wells. Table 5-3 gives the results of the chemical analysis made for this study. The concentration of certain dissolved constituents may change between the time of field collection and the time of laboratory analysis owing to loss of gases, temperature changes, and precipitation of solids. Certain analyses were made in the field and parts of the samples were treated before analysis.

Due to the unimproved condition of most of the springs encountered during this investigation and occasionally the precipitous conditions under which the springs occur few attempts were made to measure the flow. However, estimates of the flow rate were made based on the field personnel's experience and on approximate measurements (Table 5-2).

Temperature of the spring waters were measured to the nearest $0.1 \mathrm{C}(0.18 \mathrm{~F})$ as close to spring orifice as possible and the temperature of the well water was measured as close to the wellhead as possible. These data are listed in Table 5-2.

Silica was measured in the field with a HACH Chemical Company field test kit, as were several other constituents. The only field analysis reported herein is silica and these values were adjusted as explained in Section 5.4.5. All other field determinations were abandoned because of inaccuracies introduced through severe environmental conditions encountered during the field investigation.

A separate bottle of each sample was acidified at the time of collection and taken to the laboratory for analysis for aluminum ( $\mathrm{Al}$ ), iron ( $\mathrm{Fe}$ ), manganese (Mn), zinc $(\mathrm{Zn})$, calcium $(\mathrm{Ca})$, magnesium $(\mathrm{Mg})$, and strontium $(\mathrm{Sr})$. Analysis for these seven cations, as well as for sodium $(\mathrm{Na})$, potassium $(\mathrm{K})$, and lithium ( $\mathrm{Li}$ ) were made by atomic absorption spectroscopy. Analyses were conducted by Environmental Engineering Laboratory in San Diego, California. (In this section and those that follow, superscripts showing the ionic charge of dissolved species are not shown.) 
Table 5-2

ESTIMATED FLOW RATES OF SPRINGS AND GROUNDWATER TEMPERATURE IN THE VICINITY OF THE PINE CREEK MINE

Well Flow or Spring Letter

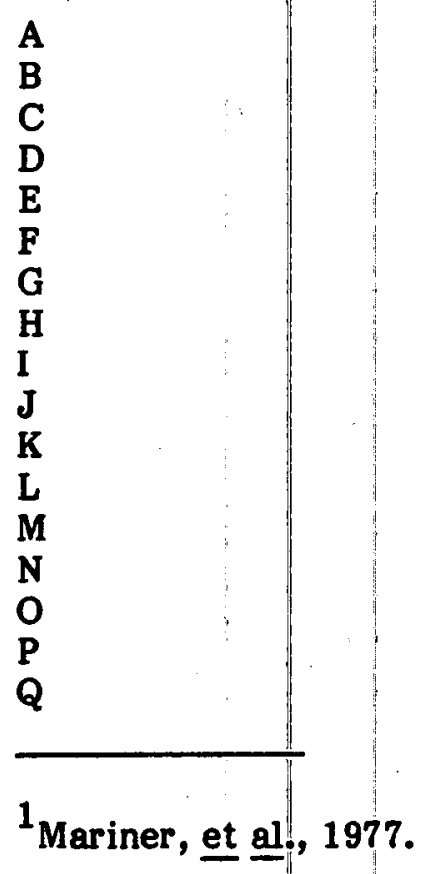

Estimate

Flow Rate

(liters/min.)

200

75 (spring system)

200

40

100

56.8 (measured)

20

80

150

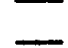

150

$>2,000^{1}$
Temperature ${ }^{\circ} \mathrm{C}$

12.3

19.9

7.6

13.4

8.3

12.7

13.4

12.9

15.0

5.6

13.9

11.3

11.6

10.7

9.0

11.8

51.4 
Table 5-3

\section{CHEMICAL ANALYSIS OF WATER FROM THE VICINITY OF THE PINE CREEK MINE AS DETERMINED DURING THIS INVESTIGATION ${ }^{1}$}

(results in milligrams per liter, except as indicated)

LOCATION OF WELL OR SPRING
(Plate I)

06S/31E - 31RS1 $07 \mathrm{~S} / 30 \mathrm{E}-8 \mathrm{CS} 1$ 06S/30E - 31 RS

$07 \mathrm{~S} / 30 \mathrm{E}-9 \mathrm{QS1}$

07S/30E - 8AS1

06S/31E - 19G1

$06 \mathrm{~S} / 30 \mathrm{E}-26 \mathrm{CS} 1$

06S/31E - 21E1

06S/31 E - 27Q1

05S/30E - 31NSI

05S/30E $-26 \mathrm{HS}$

06S/30E - 1LS1

$06 S / 31 E-17 B 1$

06S/31E - 5HI

06S/31E - 22BI

07S/31E - 20GS1

08S/33E - 17FS1

07S/30E -8 creek

NAME OF WELL
OR SPRING
seo" Spring
Going Warm Spring
y Going Cold Spring
le Creek Spring
Spring
ana Water Supply Well
ana Water Supply Spring
Und Valley School Well
Well
Post 333.5 Spring
sley Spring
lls Meadow Main Spring
th-O Ranch Well (40 acres)
th Schober Well
termilk Spring

DATE OF

COLLECTION

12-9-79

12-10-79

12-10-79

12-11-79

12-12-79

12-12-79

12-12-79

12-13-79

12-13-79

$12-14-79$

12-15-79

12-15-79

12-15-79

12-16-79

12-16-79

12-17-79

$12-18-79$

12-18-79

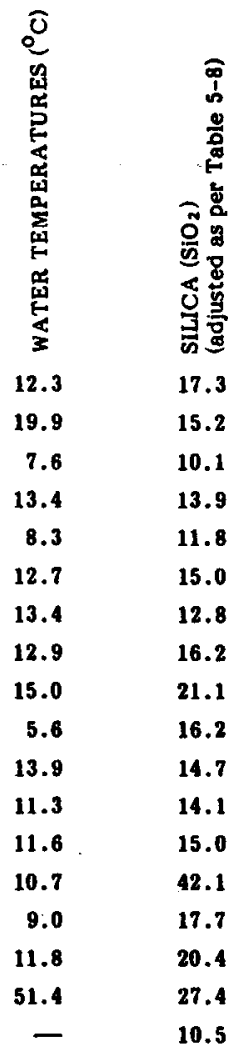

'Analysis conducted by Environmental Engineering Laboratory, 3538 Hancock Street, San Diego, Californía, 92138

2.Probably chlorinated.

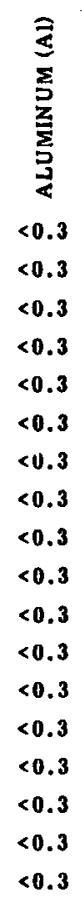


Table 5-3 Continued

CHEMICAL ANALYSIS OF WATER FROM THE VICINITY OF THE PINE CREEK MINE

OR
SPRING

LETTER LOCATION OF WELL

OR SPRING
(Plate I)

O6S/31E - $31 \mathrm{RS1}$

07S/30E - 8CS1

O6S/30E - 31 RS1

O7S/30E - 9QS1

07S/30E - 8AS1

O6S/31E - 19G1

O6S/30E - 26CS1

06S/31 E - $21 \mathrm{E1}$

$06 \mathrm{~S} / 31 \mathrm{E}-27 \mathrm{Q} 1$

05S/30E - 31NSI

05S/30E - 26HS1

06S/30E - ILS1

06S/31E - 17B1

06S/31E - 5H1

$06 S / 31 E-22 B 1$

07S/31 E - 20GS1

08S/33E - 17FSI

07S/30E - 8 creek

\section{AS DETERMINED DURING THIS INVESTIGATION ${ }^{1}$
(results in milligrams per liter, except as indicated) \\ AS DETERMINED DURING THIS INVESTIGATION ${ }^{1}$
(results in milligrams per liter, except as indicated)}


The precision of all analysis is estimated to be plus or minus one-half of the last reported digit. That is, a reported $6.9 \mathrm{mg} / 1$ implies a concentration of between 6.85 and $6.95 \mathrm{mg} / 1$. A reported analysis of $0 \mathrm{mg} / 1$ indicates that analysis was made for that constituent but the constituent was not found in concentrations greater than the detection limit. For certain ions the detection limit is listed.

\subsubsection{Quality of the Groundwater}

The chemical analyses made during this investigation are given in Table 5-3 and are arranged in order of sample collection. In addition to the analysis conducted as a part of this investigation, water quality analyses from several springs and wells in the vicinity of the Pine Creek Mine are available in the published literature and from the files of the California Department of Water Resources, southern district. Table 5-4 lists the available analysis. The sampled locations listed in both Tables 5-3 and 5-4 are shown in Plate 1.

The general chemical character of the sampled groundwater from the vicinity of the Pine Creek Mine is fresh sodium-chloride water and is shown diagrammatically in Figure 5-5. This diagram is the combined field of a trilinear diagram similar to that of Piper (1944). Also shown on Figure 5-5 are water quality data from cold and hot springs and wells in the Long Valley Caldera to the nor th of the Pine Creek Mine, Red's Meadow Hot Springs adjacent to the Devil's Postpile National Monument, Keough Hot Springs $13 \mathrm{~km}(8.1 \mathrm{mi})$ south of Bishop, and Mono Hot Springs and Blayney Meadows Hot Springs, $29 \mathrm{~km}(18 \mathrm{mi})$ west and $24 \mathrm{~km}(14.9 \mathrm{mi})$ southwest of the mine, respectively, near the terminus of California State Highway 168 (Figure 5-2). These data were taken from sources shown on the figure. The locations from which these later data were derived are listed in Table 5-5. Mole ratios of several major and minor constituents from groundwater investigated during this study are listed in Table 5-6 for the groundwaters listed in Table 5-3.

Lithologic control of the general chemical character of the groundwater in the study area was previously alluded to and is shown in Figure 5-5. Sample clustering on this figure indicates a definite separation in the chemical character of groundwater from volcanic rock aquifers (Long Valley Caldera and Red's Meadows Hot Springs) and basement rock (and basement rock derived alluvium) aquifers. Groundwater from alluvial aquifers derived from mixed basement rock and volcanic rock sources cluster between the chemical character fields for the two primary sources. A large number of additional samples would probably obscure these relationships. Groundwater Sample B from the warm spring group in a drift of the Easy Going adit at the Pine Creek Mine also plots between the groundwaters derived from granitic and volcanic rocks. Sample B was collected from an area of marble and quartz monzonite as was Sample C, a cold spring farther into the Easy Going adit. The higher percentage of $\mathrm{Li}+\mathrm{Na}+\mathrm{K}$ relative to $\mathrm{Ca}+\mathrm{Mg}$ for the warm spring is thought to be a consequence of increased water-rock reaction due to the slight heating of the warm water or possibly through mixing of considerably hotter water with the local cold water. Keough Hot Springs ( $Q$ and 10 on Figure 5-5), Mono Hot Springs (12), and Blayney Meadows Hot Springs (13) plot in a position considerably removed from the granitic rock source field, possibly due to increased rock-water reaction at the higher temperature. 
Table 5-4

GROUNDWATER QUALITY ANALYSIS IN THE VICINITY OF THE

PINE CREEK MINE OBTAINED FROM A LITERATURE AND

AGENCY SEARCH

(Exclusive of geothermal areas)

LOCATION TEMP

collected). $\quad{ }^{\circ} \mathrm{C}$

$\begin{array}{lllllllll}\mathrm{Ca} & \mathrm{Mg} & \mathrm{Na} & \mathrm{K} & \mathrm{Cl} & \mathrm{F} & \mathrm{HCO}_{3} & \mathrm{SO}_{4} & \mathrm{NO}_{3}\end{array}$

04S/29E-36RS1 10 (11-8-59)

$205 S / 30 \mathrm{E}-14 \mathrm{ES}$ (11-8-59)

$305 \mathrm{~S} / 30 \mathrm{~B}-26 \mathrm{HS} 1$ (11-8-59)

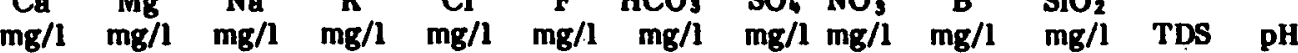

REF- ${ }^{\circ} \mathrm{C} \mathrm{Na-K}-\mathrm{C}$

ER- Geotherm-

10 .

$9.2 \quad 0.7$

6.9. $\quad 0.6$

$0.3 \quad 0.2 \quad 45$

3.30 .9

19

63

7.6

ENCE mometer REMARKS

8.3

6.10.

$\begin{array}{lllll}6.8 & 0.1 & 0.2 & 0.1 & 34\end{array}$

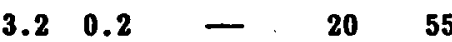

6.5

1964

Perennial spring along Sierra Front

Feth, et al., 18.2

Perennial spring

1964

along Sierra Front

"Cold" 10.0. 1 .

6.2. 0.8

$0.2 \quad 0.1$

16

63 .

Feth,

Perennial spring along Sierra Front (same as Ainsley Spring (K))

06S/31 E-19G1

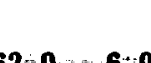
(03-02-70)

5a $06 \mathrm{~S} / 31 \mathrm{E}-20 \mathrm{H1}$ (06-25-60)

$\underset{1}{\infty}$

$5 b \quad(02-09-61)$

6a $06 \mathrm{~S} / 31 \mathrm{E}-21 \mathrm{D1}$ (07-14-55)

$6 b$ (02-09-61)

$7 a \quad 06 S / 31 \mathrm{E}-22 \mathrm{~B} 1$ (07-14-55)

$$
\text { - }
$$

29

29.0

0

$30, \quad 3.0,0.0 .3$

\section{$\begin{array}{llll}178.0 & 1.8 & 0.00\end{array}$}

$-343$

$43-7.4$

Cal. 1970

Well in Rovana

Cal. DWR WDIS File

31.0 Residential Well Ave.

$\begin{array}{ll}\text { Cal. DWR } & 27.7\end{array}$ WDIS·File $\begin{array}{lllllll}39.0 & 3: 0 & 9.0 & 3.0 & 14.0 & 0.4 & 33\end{array}$

$\begin{array}{llllllll}-40.0 & 3.0 & 14.0 & 3.0 & 14.0 & 0.1 & 27\end{array}$

$57 \quad 1.0 \quad 0.02$

Cal. DWR WDIs File

27.3 Round Valley.

Ave. School Well (H)

Cal. DWR

28.8 WDIS File

30.4

Cal..DWR

27.0 Residential Well

Ave. (Possibly same as 19.6 South Schober Well; 0)

$7 \mathbf{b}$ (02-08-61)

$$
-\quad 18.02 .
$$

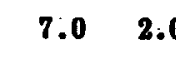

$\begin{array}{lll}2.0 & 0.1 & 33\end{array}$

9.04 .1

0.01

21.0

Cal. DWR WDIS File

12.3

$8065 / 31 \mathrm{E}-23 \mathrm{~N}$ (02-09-61)

-9 06S/31E-26E1 (02-09-61)

$10 \quad 068 / 31 E-31 J 1$ (07-14-55)

Cal. DWR WDIS File

$-19.01$

22

$\begin{array}{lllll} & \text { WDIS File }\end{array}$ Cal. DWR
WDIS File

20.0 Residential Well

10.3 Residential Well

24.1 Residential Well 


\section{ND \\ UU wESTEC Services, Inc}

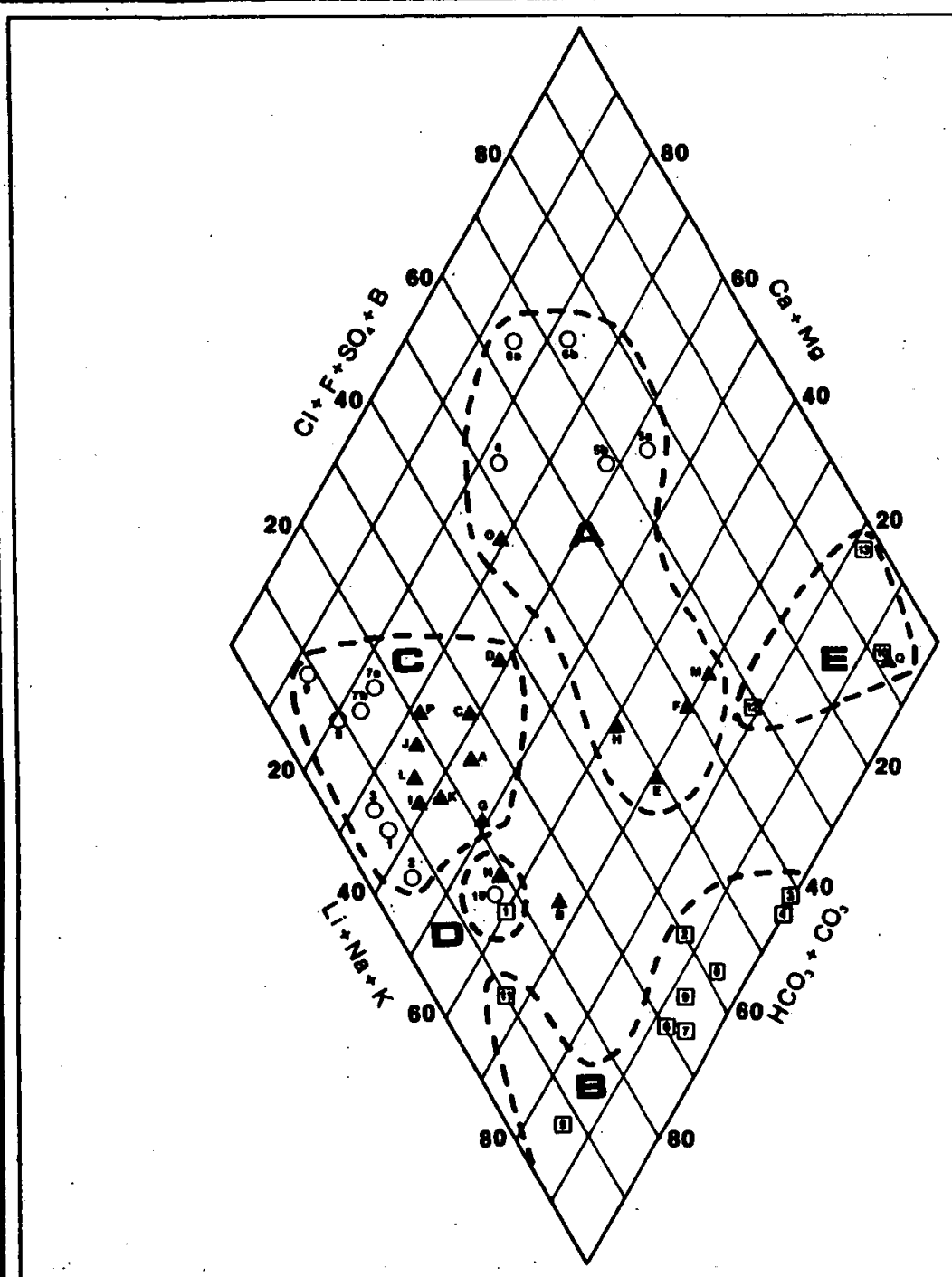

\section{DATA IDENTIFICATION AND. SOURCE}

A - Groundwater Samples A through Q. This study, Table 5-3.

O - Groundwater Samples 1. through 10, Table 5-4.

D - Groundwater Samples 1 through 9, Long Valley Caldera Cold and Hot Waters, Willey et al., 1974: Groundwater Samples 10 through 13, Sierra Nevada Hot Springs, Mariner et al., 1977, listed in Table 5-5.

\section{SAMPLE CLUSTERING}

A - Groundwater influenced by Constituents from Mill Waste from the Pine Creek Mine and Individual Chloride Sources.

B - Groundwater from Volcanic Rock.

C - Groundwater from Granitic Rock and Alluvium Derived from Granitic Rock. Some Metamorphic Rocks Present.

D - Groundwater from Mixed Granitic Rock Alluvium and Volcanic Rocks.

E - Hot Spring in Granitic Rock. 
Table 5-5

NAMES, LOCATIONS AND TEMPERATURES OF NUMBERED SPRINGS AND WELLS SHOWN ON FIGURES 5-5 AND 5-6

No.

1

2

3

4

5

6

7

8

9

10

11

12

13
Name

Big Spring Campground

Hot Spring, Little Hot Creek

Geothermal Well Magma-Ritchie

Hot Bubbling Pool

Artesian Well near N.E. Rim

Hot Spring

Hot Spring SE of Big Alkali Lake

Hot Spring $\mathrm{N}$ of Whitmore Hot Springs

Hot Spring W of Lake Crowley

Keough Hot Springs

Red's Meadow Hot Springs

Mono Hot Springs

Blayney Meadows Hot Springs
Location

02S/27E-25AS1

03S/28E-13ES1

03S/28E-32ES9

03S/28E-35ES1

03S/29E-13C1

03S/29E-21NS1

03S/29E-28HS1

03S/29E-31 AS1

03S/29E-34KS1

08S/33E-17FS1

Unsurveyed

$37^{\circ} 37$ ' $\mathrm{N}$,

$119^{\circ} 04^{\prime} \mathrm{W}$

Unsurveyed

$37^{\circ} 27$ ' ,

$119^{\circ} 01^{\prime} \mathrm{W}$

Unsurveyed

$37^{\circ} 14^{\prime} \mathrm{N}$,

$118^{\circ} 52^{\prime} \mathrm{W}$

Temperature

$\left({ }^{\circ} \mathrm{C}\right)$

11

79

94

60

10

56

49

58

41

51

45.5

43

43

1978;

NOTE: Numbers 1 through 9 from Willey, et al., 1974
Numbers 10 through 13 from Mariner, et 2 al., 1977. 


\subsubsection{Groundwater of Round Valley and Pine Creek Canyon}

Several of the analyses given in Tables 5-3 and 5-4 are not of particular use in describing the natural chemical character of the groundwaters. The Round Valley School Well $(\mathrm{H})$ and the Rovana Water Supply Well $(\mathrm{F})$ were found to have chlorinators upstream from the sampling point. The South Schober Well (0) water sample was collected from a polyvinylchloride pipe and the C-BAR-0 Ranch Well (M) had been recently washed, presumably with dilute hydrochloric acid, which would also account for the water from this well having the lowest observed $\mathrm{pH}$ (6.41). The unnamed residential well (5) in Table 5-4 also has an anomalously high chloride content and may not be representative. The observed chloride anomaly in these waters account for a portion of the segregation of these samples into a separate chemical character grouping from the remainder of the groundwater from geologically similar sources as shown in Figure 5-5. Chloride concentrations in the aforementioned water are not sufficiently high to show up in more than one of the chloride containing molar ratios listed in Table 5-6. This ratio $\left(\mathrm{SO}_{4} / \mathrm{Cl}\right.$ ) is probably influenced by the anomalous sulfate content.

Several of the groundwater samples collected from downstream of the Pine Creek Mine contain anomalous sodium and sulfate concentrations (Table 5-3: E, F, H, M, and O; Table 5-4: 4, 5, and 6). Sodium sulfate brine is a waste product produced during tungsten ore processing at the Pine Creek Mine complex. Until removal of this waste product to subsurface disposal areas at Owens Lake began in 1973, process water containing the sodium sulfate was added to the tailings stream.

Figure 5-6 shows possible contours of sulfate concentration during the early to mid-1960s (from Table 5-4) and for 1979. A migration of sulfate concentration contours toward the mouth of Pine Creek Canyon is suggested to have occurred from the early 1960 s to 1979 . This is believed to show a rapid rate of groundwater movement through the alluvium of Round Valley as well as a cleansing effect of trucking the sodium sulfate waste from the mine.

The $\mathrm{Li} / \mathrm{Na}$ ratio (Table 5-6) of the groundwater of most samples from Round Valley show the marked influence of the abnormal sodium content introduced through milling activity. The anomalous sulfate content is masked in the $\mathrm{SO}_{4} / \mathrm{Cl}$ ratio by the abnormal chloride mentioned above. Because of the suspect nature of the sodium content in these waters (Table 5-3: E, F, H, M, and O), cation geothermometers cannot be meaningfully applied (Section 5.4.2, below).

\subsection{GEOCHEMICAL PREDICTION OF AQUIFER TEMPERATURE}

\subsubsection{Introduction}

Geochemical methods of estimating the subsurface temperatures at which water-rock reactions have equilibrated have been developed by several investigators. Basic assumptions inherent in the utilization of these methodologies have been provided by Fournier, et al. (1974) and the techniques of estimating the subsurface temperature has been reviewed by Fournier and Truesdell (1974) and Fournier (1977). The subsurface temperature estimating procedures are the $\mathrm{Na} / \mathrm{K}$, the $\mathrm{Na} / \mathrm{K} / \mathrm{Ca}$, and the silica geothermometers. 
Table 5-6

MOLE RATIOS OF THE MAJOR AND MINOR CONSTITUENTS IN THE GROUNDWATERS FROM THE VICINITY OF THE PINE CREEK MINE

$\frac{\mathrm{Ca}}{\mathrm{Na}} \frac{\mathrm{Mg}}{\mathrm{Ca}} \times 10^{2} \quad \frac{\mathrm{Na}}{\mathrm{K}} \frac{\mathrm{Na}}{\mathrm{Li}} \quad \frac{\mathrm{Na}}{\mathrm{Cl}} \quad \frac{\mathrm{HCO}_{3}}{\mathrm{Cl}} \quad \frac{\mathrm{SO}_{4}}{\mathrm{Cl}} \frac{\mathrm{F}}{\mathrm{Cl}} \times 10^{2} \frac{\mathrm{B}}{\mathrm{Cl}} \times 10^{2}$

$\begin{array}{lrrrrrrrrr}\text { A } & 45.17 & 5 & 8.50 & 482.93 & 4.11 & 7.17 & 0.86 & 46 & 0 \\ \text { B } & 25.52 & 0 & 38.27 & 226.37 & 5.55 & 6.28 & 0.53 & 59 & 0 \\ \text { C } & 51.00 & 19 & 17.01 & 226.37 & 3.08 & 4.46 & 0.55 & 14 & 0 \\ \text { D } & 44.20 & 11 & 19.13 & 181.10 & 4.96 & 6.43 & 1.71 & 80 & 0 \\ \text { E } & 11.60 & 38 & 63.17 & 1307.93 & 13.37 & 6.59 & 4.92 & 60 & 0 \\ \text { F } & 10.30 & 88 & 31.30 & 3471.04 & 14.19 & 5.58 & 6.86 & 30 & 4.1 \\ \text { G } & 36.98 & 96 & 9.57 & 905.49 & 6.94 & 10.17 & 1.44 & 17 & 0 \\ \text { H } & 13.11 & 9 & 23.04 & 2112.81 & 12.95 & 7.20 & 5.39 & 20 & 0 \\ \text { I } & 45.39 & 30 & 8.00 & 804.88 & 6.17 & 14.53 & 0.76 & 45 & 0 \\ \text { J } & 88.95 & 19 & 3.64 & 452.74 & 3.08 & 8.13 & 0.71 & 57 & 0 \\ \text { K } & 44.48 & 11 & 9.72 & 482.93 & 6.17 & 11.91 & 0.61 & 80 & 6.1 \\ \text { L } & 55.31 & 10 & 6.91 & 653.96 & 5.01 & 10.46 & 0.61 & 18 & 11.0 \\ \text { M } & 9.37 & 10 & 34.02 & 3139.03 & 14.07 & 4.59 & 7.45 & 16 & 3.7 \\ \text { N } & 23.72 & 15 & 11.60 & 348.26 & 7.71 & 10.46 & 1.12 & 37 & 1.5 \\ \text { O } & 32.45 & 13 & 18.55 & 1448.78 & 3.08 & 4.31 & 2.80 & 5 & 1.7 \\ \text { P } & 44.29 & 21 & 7.48 & 830.03 & 4.24 & 9.59 & 1.38 & 11 & 3.0 \\ \text { Q } & 2.14 & 0.4 & 90.14 & 99.98 & 1.31 & 0.11 & 0.14 & 6 & 0.8\end{array}$


UU $\int_{\text {WESTEC Services, Inc. }}$

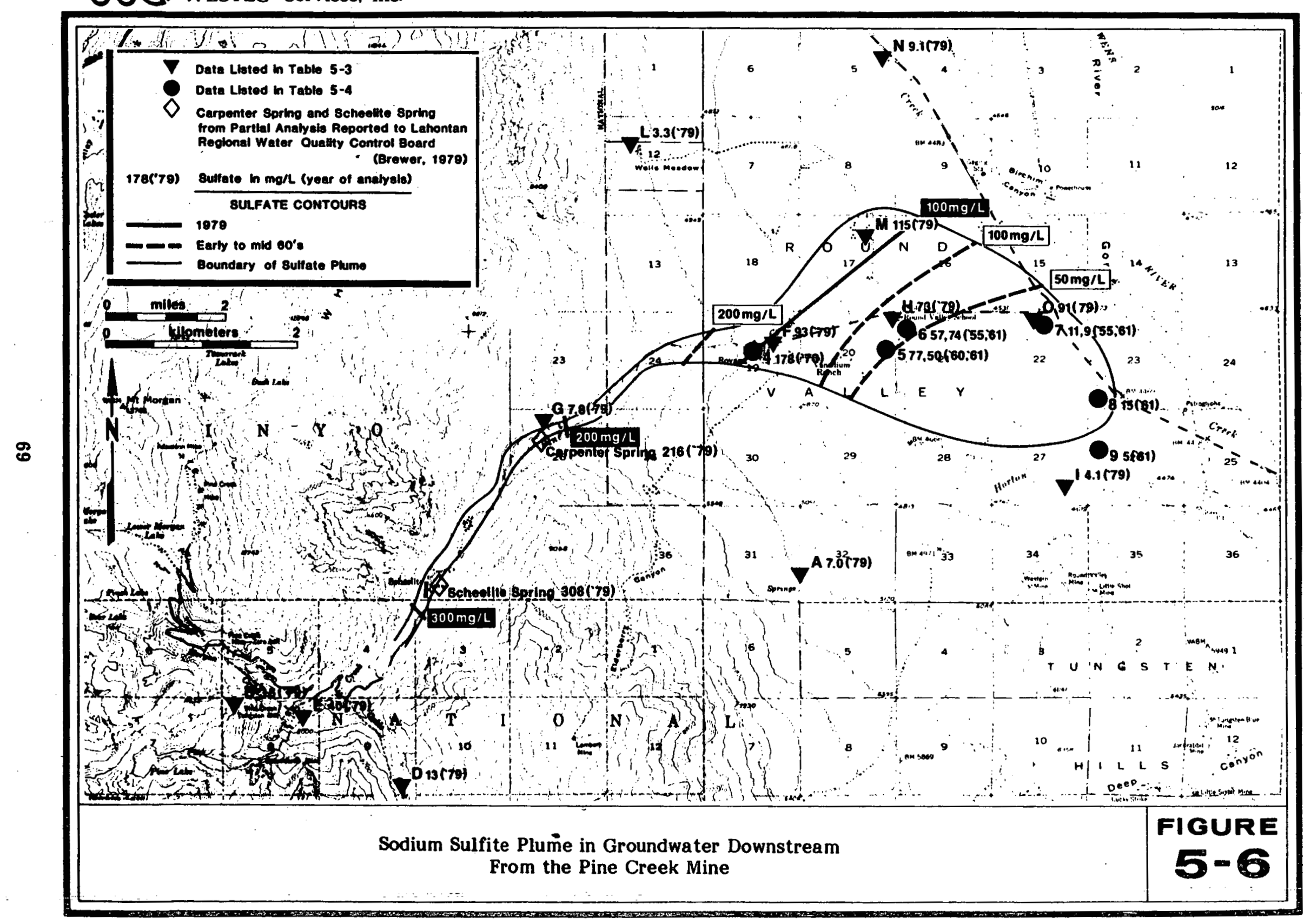


Chemical geothermometers utilizing ratios of $\mathrm{Na}$ and $\mathrm{K}$ have been refined since their inception in the mid-1960s. The most recent revision of the Na/K geothermometer was presented by Fournier (1979) and is expressed by the equation:

$$
\mathrm{T}^{\circ} \mathrm{C}=\frac{1217}{\log (\mathrm{Na} / \mathrm{K})-1.483}-273.15
$$

where $\mathrm{Na}$ and $\mathrm{K}$ are in $\mathrm{mg} / \mathrm{l}$.

The $\mathrm{Na} / \mathrm{K}$ geothermometer reportedly works well for waters equilibrated from 150 to $200 \mathrm{C}$ ( 302 to $392 \mathrm{~F}$ ) and gives anomalously high results for waters in environments of less than about $100 \mathrm{C}$ (212F) (Fournier, 1979). Table 5-7 lists the $\mathrm{Na} / \mathrm{K}$ temperatures for waters encountered during this investigation. Calculated temperatures ranged from 123.8 to $322.1 \mathrm{C}(254.8$ to $611.8 \mathrm{~F})$. These temperatures are considerably higher than the measured temperatures of the cold springs and are considered unreliable. The $\mathrm{Na} / \mathrm{K}$ temperature for the Easy Going Warm Spring is lower than the Na/K temperature calculated for the cold springs as is that for Keough Hot Springs, Mono Hot Springs and Blayney Meadows Hot Springs. The indicated equilibrium temperature of the Easy Going Warm Spring is below $150 \mathrm{C}$ (302F) but above $100 \mathrm{C}(212 \mathrm{~F})$ and therefore the geothermometer may not be applicable. However, this suggests that heating of the waters of the Easy Going Warm Spring above its discharge temperature may have occurred.

\subsubsection{Cation Geothermometers: $\mathrm{Na} / \mathrm{K} / \mathrm{Ca}$}

The $\mathrm{Na} / \mathrm{K} / \mathrm{Ca}$ geothermometer was introduced by Fournier and Truesdell (1973) to account for the anomalously high temperatures indicated by the early versions of the $\mathrm{Na} / \mathrm{K}$ geothermometer for waters equilibrating below about $100 \mathrm{C}(212 \mathrm{~F})$. Corrections to the $\mathrm{Na} / \mathrm{K} / \mathrm{Ca}$ geothermometer have been suggested for partial pressure of carbon dioxide by Paces (1978) and for magnesium concentration by Fournier and Potter (1978). The applicability of the $\mathrm{CO}_{2}$ correction has been questioned by Mariner, et al (1977). The $\mathrm{Na} / \mathrm{K} / \mathrm{Ca}$ geothermometer is based on the equation:

$$
\begin{aligned}
& \log (\mathrm{Na} / \mathrm{K})+\beta \log (\sqrt{\mathrm{Ca} / \mathrm{Na}})=\frac{1647}{273.15+\mathrm{T}^{\circ} \mathrm{C}}-2.24 \\
& \text { where } \mathrm{Na}, \mathrm{K} \text {, and } \mathrm{Ca} \text { are in moles per kilogram. } \\
& B=1 / 3 \text { for waters equilibrated above } 100 \mathrm{C} \text {. } \\
& \beta=4 / 3 \text { for waters equilibrated below } 100 \mathrm{C} \text {. }
\end{aligned}
$$

The $\mathrm{Na} / \mathrm{K} / \mathrm{Ca}$ temperatures for groundwater in the Pine Creek Mine area that have not been shown to be influenced by human activity are listed in Table 5-7. Temperatures for both $\beta=1 / 3$ and $\beta=4 / 3$ are given. $\mathrm{Na} / \mathrm{K} / \mathrm{Ca}$ temperatures for $\beta=4 / 3$ more closely approximate the observed temperature of the cold springs than do the $\beta=$ $1 / 3$ temperatures or the $\mathrm{Na} / \mathrm{K}$ temperature. The $\beta=4 / 3$ temperatures ranged from 13.4 to $37.1 \mathrm{C}(56.1$ to $98.8 \mathrm{~F})$ for groundwater from granitic and metamorphic rock. Figure 5-7A is a plot of the $\mathrm{Na} / \mathrm{K} / \mathrm{Ca}$ temperature against the measured temperature. 
Table 5-7

MEASURED SPRING AND WELL TEMPERATURES AND ESTIMATED AQUFER TEMPERATURES BASED ON CHEMICAL GEOTHERMOMETERS

(All temperatures in ${ }^{\circ} \mathrm{C}$ )

\begin{tabular}{|c|c|c|c|c|c|c|c|c|c|}
\hline 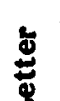 & 导 & & $\begin{array}{l}\text { Exchang } \\
\text { remome }\end{array}$ & & r & ${ }_{\text {A }}^{\text {Silica }}$ & $\begin{array}{l}\text { thermo } \\
\text { ited Sil }\end{array}$ & $\begin{array}{l}\text { neters } \\
\text { ca) }\end{array}$ & \\
\hline 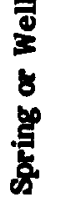 & 总 & - & 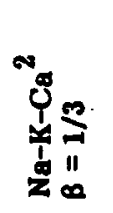 & 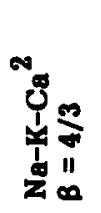 & $\frac{8}{3}$ & $\begin{array}{l}\stackrel{8}{8} \\
\frac{8}{0} \\
\frac{8}{0}\end{array}$ & $\begin{array}{l}\frac{8}{7} \\
\frac{8}{8} \\
\frac{8}{8} \\
\frac{0}{8} \\
0 \\
0\end{array}$ & 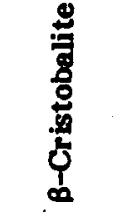 & $\begin{array}{l}\frac{9}{8} \\
\frac{8}{8} \\
\frac{8}{8} \\
4\end{array}$ \\
\hline $\mathbf{A}$ & 12.3 & 231.3 & 169.5 & 33.2 & 58.1 & 25.8 & 9.2 & -34.5 & -50.4 \\
\hline B & 19.4 & 123.8 & 110.6 & 15.9 & 53.4 & 21.0 & 4.8 & -38.5 & -54.2 \\
\hline C & 7.6 & 175.3 & 134.5 & 13.4 & 39.6 & 6.8 & -8.3 & -50.4 & -65.2 \\
\hline D & 13.4 & 167.0 & 131.5 & 15.0 & 50.3 & 17.8 & 1.8 & -41.2 & -56.7 \\
\hline $\mathbf{B}$ & 8.3 & $N / A$ & $\mathbf{N} / \mathbf{A}$ & $N / A$ & 44.7 & 12.1 & -3.5 & -48.0 & -61.2 \\
\hline $\mathbf{F}$ & 12.7 & $\mathbf{N} / \mathbf{A}$ & $\mathbf{N} / \mathbf{A}$ & $N / A$ & 53.0 & 20.5 & 4.3 & -38.9 & -54.5 \\
\hline G & 13.4 & 220.8 & 168.8 & 36.9 & 47.5 & 14.9 & -0.9 & -43.6 & -59.0 \\
\hline H & 12.9 & $\mathbf{N} / \mathbf{A}$ & N/A & $\mathbf{N} / \mathbf{A}$ & 65.7 & 23.4 & 6.8 & -36.1 & -52.3 \\
\hline I & 15.0 & 236.8 & 172.5 & 34.6 & 65.5 & 33.5 & 16.2 & -28.0 & -44.4 \\
\hline $\mathbf{J}$ & 5.6 & 322.1 & 204.1 & 31.8 & 55.7 & 23.4 & 6.9 & -36.5 & -52.3 \\
\hline $\mathbf{K}$ & 13.9 & 219.4 & 162.9 & 30.4 & 52.3 & 19.8 & 3.7 & -39.5 & -55.1 \\
\hline L & 11.3 & 250.9 & 176.8 & 31.7 & 50.8 & 18.3 & 2.3 & -40.8 & -56.3 \\
\hline $\mathbf{M}$ & 11.6 & $\mathbf{N} / \mathbf{A}$ & $\mathbf{N} / \mathbf{A}$ & $\mathbf{N} / \mathbf{A}$ & 53.0 & 20.5 & 4.3 & -38.9 & -54.5 \\
\hline $\mathbf{N}$ & 10.7 & 204.6 & 164.6 & 47.4 & 94.0 & 63.5 & 43.7 & -2.5 & -20.7 \\
\hline 0 & 9.0 & $\mathbf{N} / \mathbf{A}$ & $\mathbf{N} / \mathbf{A}$ & N/A & 58.9 & 26.7 & 10.0 & -33.7 & -49.7 \\
\hline $\mathbf{P}$ & 11.8 & 243.2 & 176.5 & 37.1 & 64.2 & 32.1 & 15.0 & -29.1 & -45.5 \\
\hline $\mathbf{Q}$ & 51.4 & 80.9 & 109.4 & 82.1 & 75.7 & 44.2 & 26.0 & -18.9 & -36.0 \\
\hline No. & 51 & 96.9 & 102 & 75 & 96 & 52 & 33 & - & 3 \\
\hline No. & 45.5 & 155.9 & 130 & 65 & 161 & 127 & 105 & 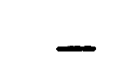 & 66 \\
\hline $\begin{array}{l}N \\
1\end{array}$ & 43 & 130.4 & 122 & 80 & 110 & 81 & . $\quad 62$ & - & 26 \\
\hline & 43 & 121.3 & 110 & 57 & 102 & 70 & 52 & - & 17 \\
\hline
\end{tabular}

$1_{\text {Method of Fournier, } 1979 .}$

${ }^{2}$ Method of Foumier and Truesdell, 1973; Magnesium correction of Fournier and Potter, 1978 not applicable and carbon dioxide deviation noted by Paces, 1975 ignored on account of Mariner et al, 1977 and low $\mathrm{CO}_{2}$ content.

${ }^{3}$ Based on equations in Table 5-9 from Fournier, 1977.

From Mariner, et a․, 1977; 10, Keough H.S.; 11, Red's Meadow H.S.; 12, Mono H.S.; 13, Blayney Meadows H.S. 


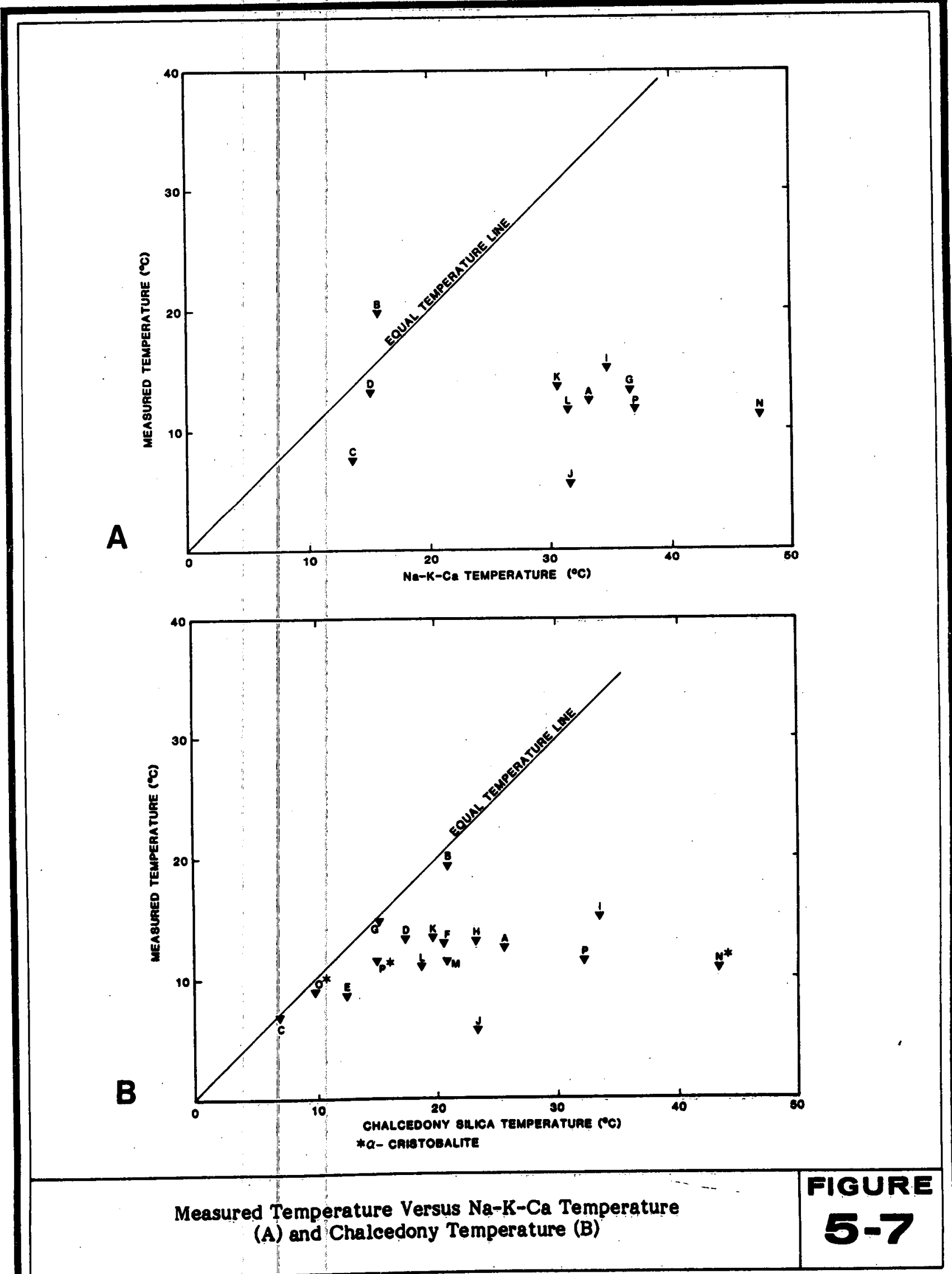


The only groundwater for which the calculated temperature is below the observed temperature is the Easy Going Warm Spring.

\subsubsection{Explanation of Cation Geothermometer Results}

The above observation suggests that either the waters issuing from the warm spring are not equilibrated with the rock at the temperature of the warm spring, or that mixing of two waters of totally different geochemical history has occurred. Cation geothermometers for Keough Hot Springs determined for this investigation agree favorably. The geothermometers applied to the data of Mariner et al. (1977) are reasonably close for Keough Hot Springs, but are considerably different for Red's Meadow Hot Springs, Mono Hot Springs, and Blayney Meadows Hot Springs (Table 5-7). This suggests that the waters of the Easy Going Warm Spring may have been heated to a temperature below that to which the waters of Keough Hot Springs were heated, but possibly to a temperature as high as that to which the other hot spring waters were heated.

The discrepancy noted between the observed temperature and the $\mathrm{Na} / \mathrm{K} / \mathrm{Ca}$ temperature of the cold groundwater could be due to a general mixing of heated water with the regional groundwater discharging as Sierra Frontal Springs or a general heating of all of the groundwater discharging from these springs. (The magnitude of the discrepancy between the cation geothermometer and measured temperature is unlikely to be accounted for by either of these hypothesis since spring $J$, which presumably consists of locally infiltrated groundwater discharging from a lateral moraine and has not passed through the bedrock (Bateman, 1965), is also affected.) A more likely explanation is a confirmation of the observations of Mariner, et al. (1977) that "in the Sierra Nevada, changes in the $(\sqrt{\mathrm{Ca} / \mathrm{Na}})$ ratio (on which the geothermometer is based) may be a function of the total dissolved solids (as controlled by other phenomena) rather than the temperature of the aquifer."

\subsubsection{Silica as a Basis for Estimating Aquifer Temperature}

The solubility of silica minerals in water increase with an increase in temperature. Under natural conditions, silica minerals dissolve until a saturated solution is formed many times faster than they precipitate from an oversaturated solution. Thus, a groundwater will dissolve silica minerals as its temperature rises, but as the water cools it will not rapidly lose silica from solution. Because of these relations, the silica concentration of a water can be used as a measure of the maximum temperature reached by the water (Fournier and Rowe, 1966; Fournier, 1973).

The actual silica concentration of a groundwater depends on the particular silica mineral to which the groundwater is exposed, as well as the temperature and the time available in which dissolution can occur. In the fractured crystalline rock groundwater system of the Pine Creek Mine the only silica mineral which groundwater comes in contact with is quartz in the granitic and metamorphic rocks (Bateman, 1965; Posner 1979). In addition to quartz, groundwater in Round Valley downgradient from the mine comes in contact with several silica species where it is influenced by the Bishop Tuff; notably chalcedony and cristobalite (Sheridan, 1975). Low concentrations of silica in groundwater are also controlled by weathering reactions of the silicate minerals during rock decomposition (Feth, et al., 1964). 
The silica concentrations of groundwater investigated during this study were determined in the field within an hour of the sample collection using a HACH Chemical Company High Range Silica Test Kit. Field analyses were performed twice and the average value was recorded in the field notes and is listed in Table 5-8. Variations in the field analysis never varied by more than $2 \mathrm{mg} / \mathrm{l}$ (except for sample $\mathrm{N}$, which varied by $10 \mathrm{mg} / 1)$. Laboratory analysis was performed on water samples which had been stored under refrigeration for up to two months. The silica concentrations determined during laboratory analysis were consistently lower than the field determined concentration (Table 5-8). The ratio: field value/laboratory value ranged between 1.70 and 2.86 if the higher values of samples $N$ and $Q$ are excluded. The average ratio is 2.10. Because of the narrow range over which the field/laboratory ratio varied, the personto-person variability of the field test method, and the reproducibility of the laboratory method, the silica concentration used for this study was adjusted by multiplying the laboratory value by the average field/laboratory ratio (Tables 5-3 and 5-8) to obtain an adjusted silica concentration. As mentioned later and in the notes to Table 5-8, this discrepancy in laboratory and field analysis may be due either to polymerization of silica or precipitation of a silica species such as chalcedony.

Figure 5-8 is a plot of the adjusted silica concentration versus the temperature of the source from which the water sample was collected. Also shown are the solubility lines for four silica minerals (quartz, chalcedony, $\alpha$ - and $\beta$-cristobalite) extrapolated from data presented by Fournier (1977). All of the samples are oversaturated with respect to quartz. The Easy Going Cold Spring and Keough Hot Springs were undersaturated with respect to chalcedony. The silica determination for Keough Hot Springs presented by Mariner, et al. (1977) shows this water to be oversaturated with respect to chalcedony. Except for samples $C$ and $Q$, each of the other samples were also oversaturated with respect to chalcedony. Sample N (the North Schober Well) is clearly oversaturated with respect to $\alpha$-cristobalite, a possible reflection of the Bishop Tuff aquifer from which it was collected. Sample P (Buttermilk Spring), from granitic rock alluvium, is slightly oversaturated with respect to $\alpha$-cristobalite and may represent analytical error since only a field determination is available for this sample. Oversaturation of the samples with respect to chalcedony suggests that this species may have precipitated in the geological environment from which the samples came and could mean that this species may have precipitated during sample storage, which would account for the discrepancy between field and laboratory analysis.

\subsubsection{Silica Temperatures}

Measured spring or well temperature and maximum temperature calculated from the various silica species equilibrium relations are shown in Table 5-7 for the adjusted silica concentrations. Equations used to calculate silica equilibrium temperatures are given in Table 5-9. Quartz temperatures of groundwater from granitic and metamorphic rock terrain range from 39.6 to $65.5 \mathrm{C}$ (103.3 to $149.9 \mathrm{~F})$ and chalcedony temperatures ranged from 12.1 to $33.5 \mathrm{C}$ (53.8 to $92.3 \mathrm{~F}$ ) (both exclusive of Keough Hot Springs). Chalcedony temperatures are closer to the observed temperatures of the cold springs and are also more compatible with the $\mathrm{Na} / \mathrm{K} / \mathrm{Ca}$ temperatures. Figure 5-7B shows the relationship between measured temperature and silica temperature.

Figure 5-9 shows the relationship between the silica species temperature which is most compatible with the $\mathrm{Na} / \mathrm{K} / \mathrm{Ca}$ temperature (generally the chalcedony 
Table 5-8

ADJUSTMENTT OF SILICA VALUES FOR OBSERVED INCONSISTENCIES

\begin{tabular}{|c|c|c|c|c|}
\hline $\begin{array}{l}\text { Well } \\
\text { or } \\
\text { Spring } \\
\text { Letter }\end{array}$ & $\begin{array}{l}\text { Field }^{1} \\
\text { Determined } \\
\text { Silica } \\
(\mathrm{mg} / \mathrm{l})\end{array}$ & $\begin{array}{c}\text { Laboratory } \\
\text { Determined } \\
\text { Silica } \\
(\mathrm{mg} / \mathrm{l})\end{array}$ & $\begin{array}{c}\text { Ratio: } \\
\text { Field } \\
\text { Laboratory }\end{array}$ & $\begin{array}{l}\text { Adjusted } \\
\mathrm{SiO}_{2}\end{array}$ \\
\hline & 15.0 & 8.2 & 1.83 & 17.3 \\
\hline & 16.5 & 7.2 & 2.29 & 15.2 \\
\hline & 10.5 & 4.8 & 2.18 & 10.1 \\
\hline & 13.5 & 6.6 & 2.04 & 13.9 \\
\hline & 10.5 & 5.6 & 1.89 & 11.8 \\
\hline & 13.5 & 7.1 & 1.90 & 15.0 \\
\hline & 13.5 & 6.1 & 2.21 & 12.8 \\
\hline & $16.0^{4}$ & 7.71 & 2.08 & 16.2 \\
\hline & 17.0 & 10 & 1.70 & 21.1 \\
\hline & 17.0 & 7.7 & 2.21 & 16.2 \\
\hline & $16.5^{5}$ & 7.0 & 2.36 & 14.7 \\
\hline & 14.0 & 6.7 & 2.09 & 14.1 \\
\hline & 13.0 & 7.1 & 1.83 & 15.0 \\
\hline & 80.0 & 20 & 4 & 42.1 \\
\hline & 24.0 & 8.4 & 2.86 & 17.7 \\
\hline & 20.4 & -6 & - & 20.4 \\
\hline & $(44)^{7}$ & 13 & 3.38 & 27.4 \\
\hline
\end{tabular}

Average:

$2.105^{8}$

Notes:

${ }^{1}$ Reactive silica by the Ammonium molybdate method using occular comparator colorimeter (Hach Chemical Company, Silica Test Kit, Low Range).

${ }^{2}$ Reactive silica by Ammonium molybdate method using laboratory colorimeter with comparison standards.

${ }^{3}$ Laboratory value multiplied by the average ratio between field and laboratory value (2.10). Adjustment made because of apparent loss of silica through sample ageing. The laboratory determined quantity is considered more accurate and field determined value is considered more precise. Values of silice content contained in the literature and file data, Table 5-3, agree favorably with the field determined values.

${ }^{4} 18 \mathrm{mg} / \mathrm{from}$ Cal DWR-WDIS file.

${ }^{5}{ }_{16} \mathrm{mg} / \mathrm{l}$ from Cal DWR-WDIS file.

${ }^{6}$ Not determined.

${ }^{7}$ Determined by USGS (Mariner 르 르., 1979).

${ }^{8}$ Does not include $N, P$, or $Q$. 


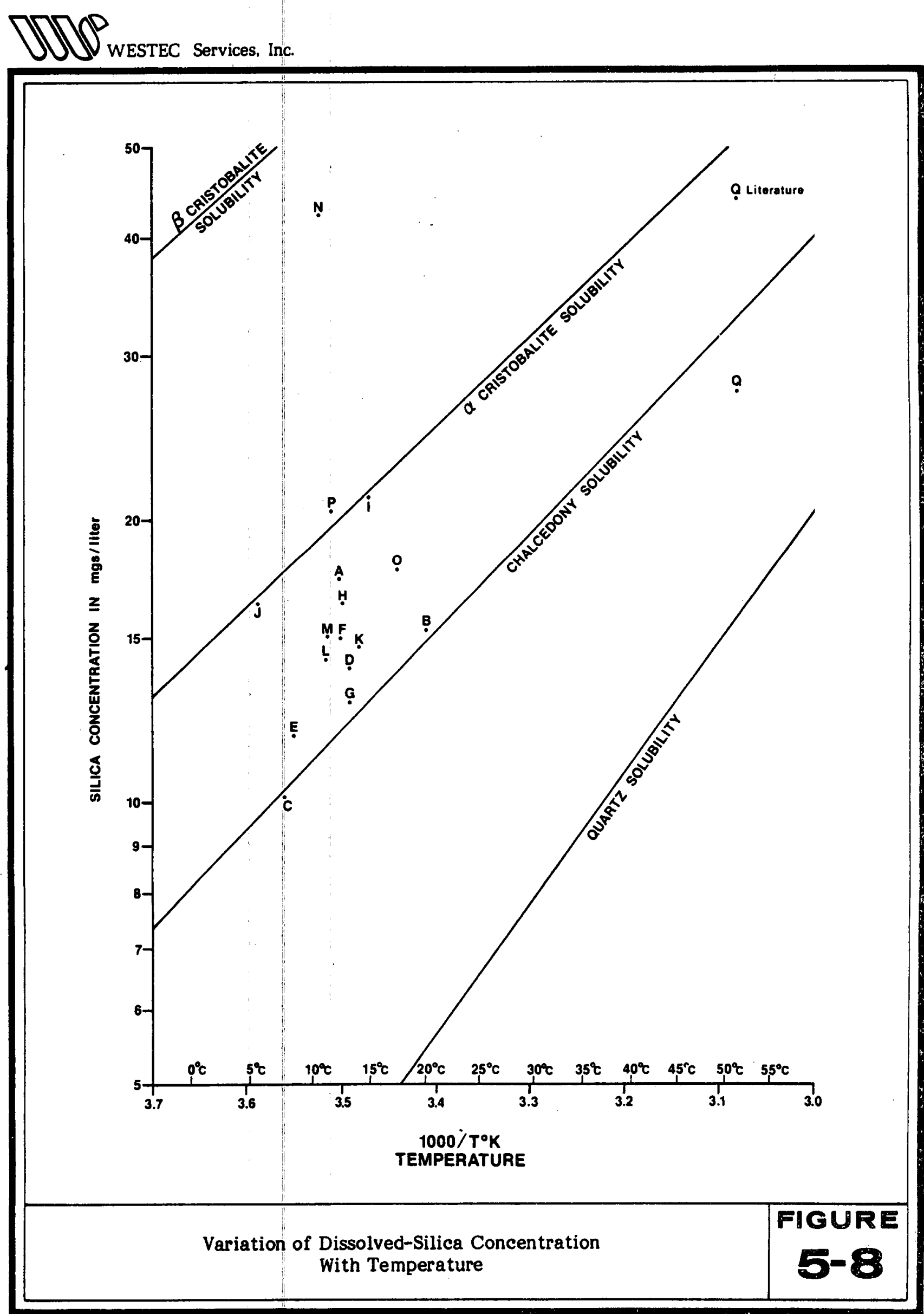


Table 5-9

EQUATIONS RELATING THE SOLUBILITY OF SILICA AS A FUNCTION OF TEMPERATURE
Amorphous silica
$\mathrm{T}_{{ }^{\circ} \mathrm{C}}=\frac{731}{4.52-\log \mathrm{C}}-273.15$
B-Cristobalite
$\mathrm{T}_{{ }_{\mathrm{C}} \mathrm{C}}=\frac{781}{4.51-\log \mathrm{C}}-273.15$
$\alpha$-Cristobalite
$\mathrm{T}_{{ }^{\circ} \mathrm{C}}=\frac{1000}{4.78-\log \mathrm{C}}-273.15$
Chalcedony
${ }^{T^{\circ} \mathrm{C}}=\frac{1032}{4.69-\log \mathrm{C}}-273.15$
Quartz

$$
\mathrm{T}_{{ }^{\circ} \mathrm{C}}=\frac{1309}{5.19-\log \mathrm{C}}-273.15
$$

Where $\mathrm{C}$ is silica solubility in $\mathrm{mg} \mathrm{SiO}_{2}$ per $\mathrm{kg}$ water.

Source: Fournier, 1977 
NU $\int_{\text {WESTEC Services. Inc. }}$

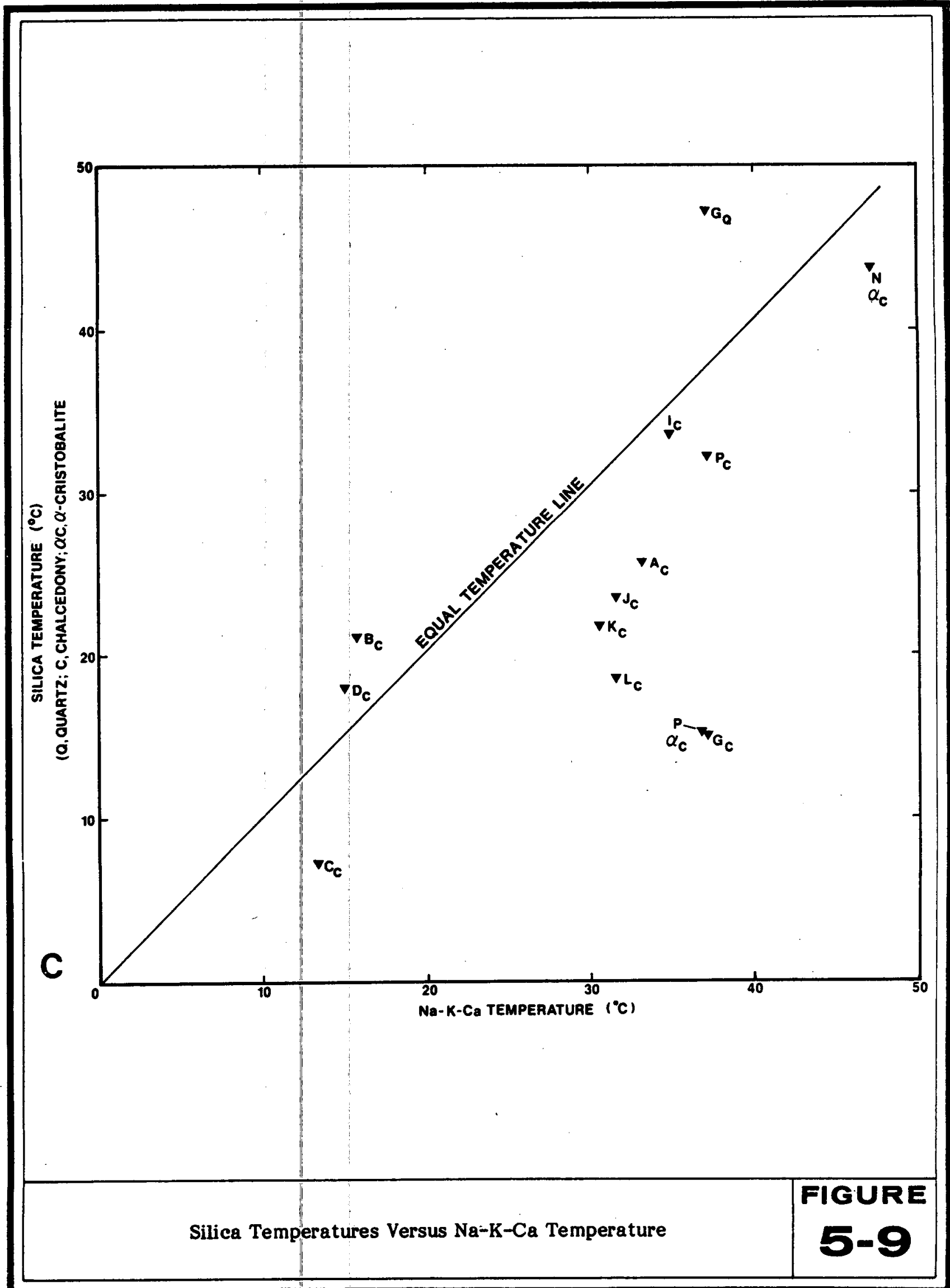


temperature) and the $\mathrm{Na} / \mathrm{K} / \mathrm{Ca}$ temperature. A general clustering of samples $\mathrm{A}, \mathrm{I}, \mathrm{J}, \mathrm{K}$, $\mathrm{L}$, and $\mathrm{P}$ occurs on this figure and on Figure 5-7A. Samples $\mathrm{B}, \mathrm{C}$, and $\mathrm{D}$ are isolated from this clustering by differences in the $\mathrm{Na} / \mathrm{K} / \mathrm{Ca}$ temperatures. The higher $\mathrm{Na} / \mathrm{K} / \mathrm{Ca}$ temperature clustered samples were derived from granitic rock alluvium (wells and springs in alluvium) and the cooler $\mathrm{Na} / \mathrm{K} / \mathrm{Ca}$ temperature samples were collected from bedrock springs. This relationship suggests that the higher mineral particle-water contact available in the porous alluvium as compared to that of flow through fractured bedrock controls exchange reactions and may in part account for the deficiency of the $\mathrm{Na} / \mathrm{K} / \mathrm{Ca}$ geothermometer noted by Mariner, et al. (1977) and quoted earlier. Because of these phenomena, only the bedrock springs $\mathrm{B}, \mathrm{C}$, and $\mathrm{D}$ are used to apply mixing models below.

\subsubsection{Silica Mixing Models}

Conceptual models allowing calculation of temperature and fraction of the hot water component in a mixture of two waters of differing geochemical history are presented by Fournier and Truesdell (1974), Truesdell and Fournier (1977) and Fournier (1977). The mixing model thought to be applicable at the Pine Creek Mine (Model 1 of Fournier and Truesdell, 1974) is one where cold groundwater geochemically similar to either cold spring $\mathrm{C}$ or $\mathrm{D}$ mixes with a hot groundwater to emerge as the Easy Going Warm Spring. Thus, in this model it is assumed that the enthalpy of the hot water component that mixes with the cold water is the same as the initial enthalpy of the deep hot water. This is expressed in the following equation (Fournier and Truesdell, 1974):

$$
\left(H_{\text {cold }}\right)(x)+\left(H_{\text {hot }}\right)(1-x)=H_{\text {spring }}
$$

where

$$
\begin{aligned}
& \mathrm{H}_{\text {cold }} \quad \text { enthalpy of the cold water, } \\
& \mathrm{H}_{\text {hot }} \quad \text { = enthalpy of the presumed hot water source, } \\
& \mathrm{H}_{\text {spring }}=\text { enthalpy of the observed warm water, } \\
& \mathrm{x} \quad=\text { fraction of cold water in the mixture, and } \\
& 1-\mathrm{x} \quad=\text { fraction of hot water in the mixture. }
\end{aligned}
$$

The silica content of a water in contact with silica minerals is related to its enthalpy (Fournier, 1973) and therefore can be used in a similar fashion (Fournier and Truesdell, 1974):

where

$$
\begin{aligned}
& \left(\mathrm{Si}_{\text {cold }}\right)(\mathrm{x})+\left(\mathrm{Si}_{\text {hot }}\right)(1-\mathrm{x})=\mathrm{Si} \text { spring } \\
& \mathrm{Si}_{\text {cold }}=\text { silica content of the cold water, } \\
& \mathrm{Si}_{\text {hot }}=\text { silica content of the presumed hot water source, } \\
& \mathrm{Si}_{\text {spring }}=\text { silica content of the observed warm water, }
\end{aligned}
$$




$$
\begin{aligned}
& \quad=\text { fraction of cold water in the mixture, and } \\
& 1-x \quad=\text { fraction of hot water in the mixture. }
\end{aligned}
$$

Figure $5-10$, is a graphical solution to the above two equations based on the method of Fournier and Truesdell (1974) for two pairs of groundwaters: Springs B and C and Springs B and D. This graphical solution to the mixing model shows that the temperature of the hot water component may be in the range of 75.9 to $99.4 \mathrm{C}$ (168.6 to 210.9F). The model also shows that the hot water component may comprise only 10 to 13 percent of the total flow of the Easy Going Warm Spring.

\subsubsection{Hydrogen and Oxygen Isotopes: Stable Isotopes}

Analysis of the stable isotopes of hydrogen (deuterium; $\mathrm{H}^{2}$ or $\mathrm{D}$ ) and of oxygen (oxygen-18; $\mathrm{O}^{18}$ ) are reported relative to an arbitrary standard which has been defined as Standard Mean Ocean Water (SMOW) (Craig, 1961a). The reported concentrations are in parts per thousand (per mil; $0 / 00$ ) deviation $(\delta)$ from this standard.

During evaporation and condensation in the hydrologic cycle, water molecules containing heavier isotopes are concentrated in the liquid phase. As water evaporates from the ocean, the vapor is depleted in $D$ and $\mathrm{O}^{18}$ and therefore their values are generally negative in waters originating as meteoric precipitation. The concentration of $\mathrm{D}$ and $\mathrm{O}^{\mathrm{P}}$ in meteoric water varies regularly over the land surface of the earth. A great number of measurements has shown that for meteoric waters not subject to much reevaporation, $\delta \mathrm{D}$ and $\delta \mathrm{O}^{18}$ are related by the Craig (1961b) meteoric water expression:

Other factors which control the $D$ and $O^{\text {i } 8}$ concentrations are altitude, latitude, and distance from the ocean.

When meteoric water enters a groundwater aquifer, isotopic as, well as chemical changes can occur to the water. An enrichment in the $\mathrm{O}^{18}$ content of groundwater has been reported for many geothermal areas (Craig, 1967) and is believed to be due to a temperature control of exchange of $\mathrm{O}^{16}$ of the water for $\mathrm{O}^{18}$ of the silicate minerals in the rock. Because of the low hydrogen concentrations of most of the rock, the $\delta \mathrm{D}$ of the waters is relatively unchanged.

Deuterium and $\mathrm{O}^{18}$ analysis of select groundwaters from the vicinity of the Pine Creek Mine are given in Table 5-10. $\delta \mathrm{D}$ ranged from -117.6 to -133.4 which is consistent with deuterium concentrations reported for Sierra Nevada snow reported by Friedman and Smith $(1970,1972)$. The range in $\delta \mathrm{D}$ reported by these authors for snow samples collected from various altitudes along the eastern escarpment of the Sierra Nevada have too great a range to allow estimations of groundwater recharge areas to be made for this study.

$\delta O^{18}$ values ranged from -16.15 to -18.18 for the groundwaters investigated. Figure 5-11 is a plot of $\delta \mathrm{D}$ versus $\delta \mathrm{O}^{18}$ for groundwaters from the vicinity of 

Table 5-10

HYDROGEN- AND OXYGEN-ISOTOPE CONCENTRATION OF GROUNDWATERS FROM THE VICINITY OF THE PINE CREEK MINE

\begin{tabular}{|c|c|c|c|c|c|}
\hline $\begin{array}{c}\text { Spring } \\
\text { or } \\
\text { Well } \\
\text { Letter } \\
\end{array}$ & Location & $\begin{array}{c}\text { Date } \\
\text { of } \\
\text { Collection } \\
\end{array}$ & $\begin{array}{c}\delta \mathrm{D} \\
\text { SMOW } \\
0 / 00 \\
\end{array}$ & $\begin{array}{c}\delta 0^{18} \\
\text { SMOW } \\
\text { o/oo } \\
\end{array}$ & $\begin{array}{l}\text { Tritium } \\
\mathrm{TU}+1 \sigma \\
\end{array}$ \\
\hline A & 06S/31E-31RS1 & $12-9-79$ & -128.7 & $\begin{array}{l}-17.74 ; \\
17.79\end{array}$ & $8.94+1.09$ \\
\hline B & $07 \mathrm{~S} / 30 \mathrm{E}-8 \mathrm{CS} 1$ & $12-10-79$ & -124.6 & -17.01 & $33.44 \pm 3.75$ \\
\hline C & 06S/30E-31RS1 & $12-10-79$ & -127.5 & -17.28 & $25.28+3.09$ \\
\hline E & $07 \mathrm{~S} / 30 \mathrm{E}-8 \mathrm{AS} 1$ & $12-12-79$ & -117.6 & -16.15 & - \\
\hline $\mathbf{F}$ & $06 \mathrm{~S} / 31 \mathrm{E}-19 \mathrm{G} 1$ & $12-12-79$ & -126.7 & -17.12 & $37.81 \pm 4.38$ \\
\hline G & $06 \mathrm{~S} / 30 \mathrm{E}-26 \mathrm{CS} 1$ & $12-12-79$ & -130.0 & -17.79 & - \\
\hline I & $06 S / 31 E-27 Q 1$ & $12-13-79$ & -125.2 & -16.95 & $55.31 \pm 6.25$ \\
\hline M & 06S/31E-17B1 & $12-15-79$ & -125.1 & -17.13 & - \\
\hline $\mathbf{Q}$ & 08S/33E-17FS1 & $12-18-79$ & -133.4 & -18.18 & 一 \\
\hline
\end{tabular}

NOTES: Deuterium and Oxygen ${ }^{18}$ analysis by Louis J. Pandolfi, Global Geochemistry Corporation.

Tritium analysis by K. Roach, Teledyne Isotopes.

SMOW means "standard mean ocean water." 


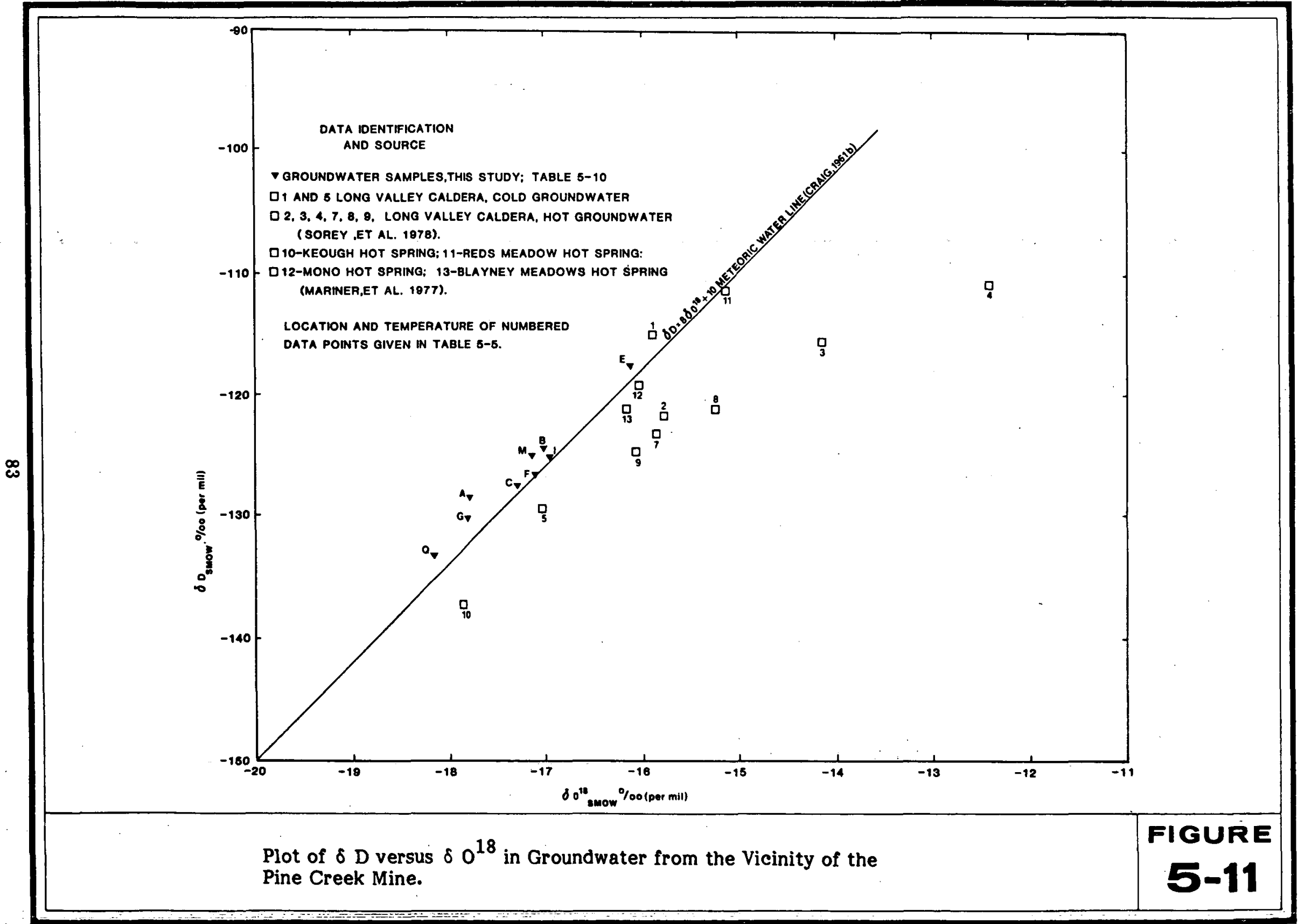


the Pine Creek Mine and for select thermal and non-thermal waters of the Long. Valley Caldera, and Red's Meadow Hot Springs, Mono Hot Springs, Blayney Meadows Hot Springs, as well as Keough Hot Springs which was also reported in this study (Spring Q).

The waters of the Easy Going Warm Spring do not show a shift in $\delta O^{18}$ from that of the local meteoric water (Spring C) or the Craig meteoric water line. However, neither do Keough Hot Springs (Q), Red's Meadow Hot Springs (11), or Mono Hot Springs (12). A slight $\delta \mathrm{O}^{18}$ shift of 0.58 per mil was reported for Keough Hot Springs and 0.20 per mil for Blayney Meadows Hot Springs by Mariner, et al. (1977). $\delta O^{18}$ shifts of hot waters of the Long Valley Caldera ranged from 0.78 to $\overline{2.68}$ (Figure 5-10) as reported by Sorey, et al. (1978). The lack of a $\delta \mathrm{O}^{18}$. shift in the waters of the Easy Going Warm Spring and the hot springs could be due to any of several phenomena. Possible explanations are: 1) heating of the waters was not to a sufficient temperature to bring about any significant isotope exchange; 2 ) water residence time in the aquifer was insufficient to bring about exchange; 3 ) the rock was of similar oxygen isotopic composition to the water; and 4) the fractures through which the water flowed were isotopically flushed. Items 1 and 2 above are the preferred explanations.

\subsubsection{Unstable Isotopes}

Tritium $\left(\mathrm{H}^{3}\right.$ or $\left.\mathrm{T}\right)$ is the unstable isotope of hydrogen. Tritium has a halflife of 12.28 years and is reported in Tritium Units (TU) which consist of one tritium atom per $10^{18}$ hydrogen atoms. Tritium is produced naturally in the upper atmosphere such that natural tritium is present in rainfall in concentrations of from 1 to $10 \mathrm{TU}$. Tritium is also produced artificially by the detonation of thermonuclear devices. Atmospheric concentration of tritium was highest from the early 1950s through 1962 when they peaked and began to decline because of the banning of the atmospheric testing of such devices. The concentration of tritium reached high levels in this period: on July 2, 1963 the concentration in Lake Crowley, a few kilometers northeast of the study area, was 420 TU (Leventhal and Libby, 1970). The highest tritium concentration reported by these authors was for rainfall at Jasper National Park, Alberta, Canada, which was 8200 TU on July $11,1963$.

Tritium concentrations were measured for five of the groundwaters sampled for this investigation (Table 5-10). The tritium concentrations are reported within one standard deviation $(1 \sigma)$ and ranged from 8.94 to 55.31 TU. Each of these analyses suggests that the spring or well from which it came has a major component of water which was derived from precipitation that fell since 1950, though probably later. Other than that a major component of each groundwater sample has been in the aquifer probably much less than 30 years, no statements of groundwater age can be made. A tritium concentration profile for precipitation in the study area is not available.

Sulfate concentration changes through time were reported above (Section 5.3.3) to indicate a short residence time for groundwater in Round Valley. The high tritium concentration in these waters ( $F$ and $I$ ) substantiates this hypothesis. A rapid aquifer or wellbore mixing of newly infiltrated water (post, 1973, high tritium, low sulfate) with older water (pre 1937: low tritium, low sulfate; 1937 to 1955: low tritium, high sulfate; 1955-1973: high tritium, high sulfate) may account for the tritium effects but not the sulfate effects. The lower tritium concentration in Spring A supports a larger old water component in the Sierra Frontal Springs. 
The tritium concentration of the Easy Going Warm Spring (B) is higher than the nearby Easy Going Cold Spring $(C)$ and suggests that either a much hotter old water mixes with a large quantity of old cold water or that a younger water, essentially the same age as the cold water, is rapidly heated to the observed temperature. The lack of $\mathrm{O}^{18}$ shift mentioned earlier adds no information on this subject.

\section{5 \\ MODEL OF THE PINE CREEK MINE LOW-TEMPERATURE GEOTHERMAL RESOURCE}

\subsubsection{Summary of Data on the Easy Going Warm Spring}

Data gathered during this investigation has been presented in the previous sections on its own merit, without detailed consideration of the integral workings of the natural environment and with few interpretations offered. Chemical geothermometers have been shown to yield seemingly conflicting results. The $\mathrm{Na} / \mathrm{K}$ geothermometer and the silica mixing model have shown temperatures of the Easy Going Warm Spring source waters to be 124 and $94 \mathrm{C}(255.2$ to $201.2 \mathrm{~F})$, respectively. The $\mathrm{Na} / \mathrm{K} / \mathrm{Ca}$ geothermometer gives a temperature of $16 \mathrm{C}(60.8 \mathrm{~F})$, and the most probable silica temperature is the chalcedony temperature at $21 \mathrm{C}(69.8 \mathrm{~F})$. The quartz temperature is $54 \mathrm{C}(129.2 \mathrm{~F})$ and is within range of the other geothermometers. If the Gable Creek Spring is assumed to be a cold spring, the silica mixing model suggests a source temperature of $76 \mathrm{C}(168.8 \mathrm{~F})$. Thus, the chemical geothermometers show a possible range of source water temperature of 16 to $124 \mathrm{C} .(60.8$ to $255.2 \mathrm{~F})$, with a higher probability for the lower end of the temperature range.

Oxygen-18 and deuterium analyses suggest that Easy Going Warm Spring has not been significantly heated. Similar observations from hot springs in the region would not allow narrowing of the possible temperature range. High tritium concentrations imply short aquifer residence times, which may not allow adequate time for the water to be heated or chemical and isotopic equilibrium to occur.

The only clear evidence found to differentiate between the hypothesis that either: 1) water of the Easy Going Warm Spring was heated to a temperature only slightly above the spring temperature (19.9C) (67.8F); or 2) an unknown quantity of significantly hotter water mixes with local cold water to produce the Easy Going Warm Spring, is the similarity in the total dissolved solids content between the cold and warm waters. To retain the observed similar and low total dissolved solids, any hot water component mixing with the local cold waters would have to be exceedingly low in total dissolved solids. This is likely only if the hot water component were condensed steam. This is improbable, and is not supported by oxygen-18 data: the steam should be enriched in $\mathrm{O}^{16}$ and thus the admixed water would show a shift away from Standard Mean Ocean Water (SMOW) and the meteoric water line (i.e., to the left of Figure 5-11). Thus, the hypothesis of local heating to a low temperature is preferred. This could be brought about if the heat generation rate of the local rock were adequate or by circulation of the groundwater to necessary depths as required by the local geothermal gradient.

\subsubsection{Heat Generation and Loss \\ Wollenberg and Smith $(1970)$ reported heat generation rates equivalent to $31 \mathrm{cal} \mathrm{m}^{-3} \mathrm{yr}^{-1}\left(0.0094 \mathrm{Btu} \mathrm{yd}^{-3} \mathrm{yr}^{-1}\right)$ and $11.7 \mathrm{cal} \mathrm{m} \mathrm{yr}^{-1}\left(0.035 \mathrm{Btu} \mathrm{yd}^{-3} \mathrm{yr}^{-1}\right)$ for}


marble and clastic metasedimentary rocks of the Paleozoic pendants of the eastern Sierra, assuming densities of $2.6 \mathrm{~g} / \mathrm{cm}^{3}\left(162.3 \mathrm{lbs} / \mathrm{ft}^{-3}\right)$. The weighted average assuming 20 percent marble and 80 percent clastics, is 9.9 cal m${ }^{-3} \mathrm{yr}^{-1}\left(0.030 \mathrm{Btu} \mathrm{yd}^{-3} \mathrm{yr}^{-1}\right)$. A heat generation rate of $21.8 \mathrm{cal} \mathrm{m}^{-3} \mathrm{yr}^{-1}\left(0.066 \mathrm{Btu} \mathrm{yd}^{-3} \mathrm{yr}^{-1}\right)$ was reported for granitics surrounding the pendant (predominently the Tungsten Hills quartz monzonite) (Wollenberg and Smith, 1968).

The Easy Going Warm Spring system discharges about 200 liters per minute $\left(52.8 \mathrm{gal} \mathrm{min}^{-1}\right)$ at $19.9 \mathrm{C}(67.8 \mathrm{~F})$. If the average annual temperature is $4 \mathrm{C}(39.2 \mathrm{~F})$, the

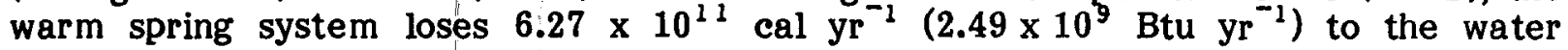
draining the mine. This amount of heat would be produced by about 63 cubic kilometers $\left(15 \mathrm{mi}^{3}\right)$ of the pendant rock or $29 \mathrm{~km}^{3}\left(7 \mathrm{mi}^{3}\right)$ of quartz monzonite. The pendant has a volume of only about $8 \mathrm{~km}^{3}\left(1.9 \mathrm{mi}^{3}\right)$ and can therefore not be locally providing all of the observed heat in the Easy Going Warm Spring. The low thermal conductivity of the rock and unaccounted groundwater effects would require an even larger volume of rock explained by deeper circulation. A model of the geothermal regime at the Pine Creek Mine is presented below.

\subsubsection{Geothermal Regime of the Pine Creek Mine}

Lachenbruch (1968) and Lachenbruch, et al. (1976) presented heat flow and heat production data for seven drillholes in granitic rocks in the Sierra Nevada not in association with the Long Valley Caldera. Four of these drillholes (ST, SJ, JB, and HC) formed a transect aligned perpendicular to the axis of the range at about $30 \mathrm{~km}$ $(18.6 \mathrm{mi})$ intervals. These are herein plotted to show the fair correlation of geothermal gradient with drill collar elevation (Figure 5-12). One of the drillholes (JA) was about $50 \mathrm{~km}(31.1 \mathrm{mi})$ north of the transect and agreed favorably with data from the transect. The remaining two drillholes (THE and THW) are in the Tungsten Hills to the east of the Sierras and within the present study area. Data from these two drillholes also agrees with the collar elevation/geothermal gradient relationship. The regular increase in geothermal gradient in granitic rocks of the Sierra Nevada with collar elevation is attributed to a regular pattern of relict heat flow and heat production in the plutonic rocks from the prebatholothic source and the erosional history of the range. Lachenbruch (1968) presented a set of graphs showing steady-state limits for crustal temperatures beneath the Sierra Nevada based on the aforementioned data (Figure 5-13). These data can be used in conjunction with the altitude relation to approximate the geothermal gradient at any station in the plutonic rock in the Sierra Nevada.

Based on the above regional model, the geothermal gradient at the Pine Creek Mine should be between 15 and $18 \mathrm{C}$ (43.5 and $52.1 \mathrm{~F}$ per mile) per kilometer of depth. Assuming the lower limit of $15 \mathrm{C} / \mathrm{km}(43.5 \mathrm{~F} / \mathrm{mi})$, which is also the gradient below the Tungsten Hills, a model of the geothermal environment at the Pine Creek Mine was developed which accounts for the field observations and laboratory analyses. This model is shown on Plate 2.

Plate 2 is a cross section through the Pine Creek Mine area from the summit of Mount Morgan to the drillhole on the eastern side of the Tungsten Hills (THE), passing through springs $\mathrm{C}, \mathrm{B}, \mathrm{D}$, and $\mathrm{A}$ and the western Tungsten Hills drillhole (THW). Geologic features shown on Plate 2 were interpreted from maps and sections prepared by Bateman (1965). The line of the cross section (Plate 2) is shown on Plate 1. Attitudes of relic bedding in the metamorphic complex and faults is approximate. 


\section{NUN $\int_{\text {WESTEC Services, Inc. }}$}

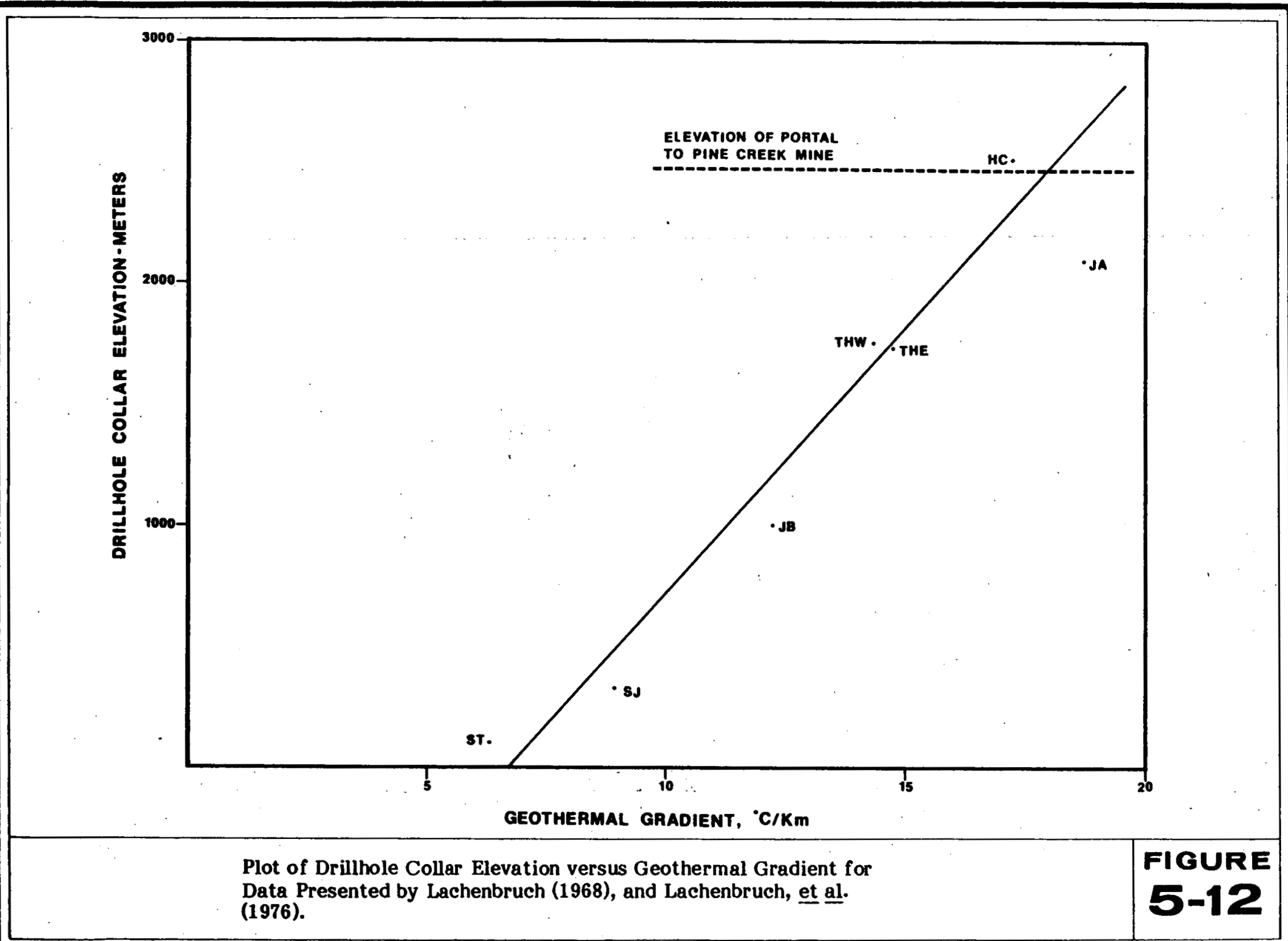


Plate 2 shows $10 \mathrm{C}(18 \mathrm{~F})$ isotherms based on a thermal gradient of $15 \mathrm{C} / \mathrm{km}$ $(43.5 \mathrm{~F} / \mathrm{mi})$ and an average ambient temperature of $14 \mathrm{C}(57.2 \mathrm{~F})$ in Round Valley and the Tungsten Hills. The measured rock temperature of $14 \mathrm{C}(57.2 \mathrm{~F})$ in the Brownstone adit of the Pine Creek Mine was used instead of the 4C (39.2F) average ambient temperature at the mine complex. The isotherms are extended across the Pine Creek pendant syncline because of the indicated $14 \mathrm{C}$ rock temperature.

As can be seen from Plate 2, temperatures of over $30 \mathrm{C}(86 \mathrm{~F})$ are expected within the pendant syncline. The metamorphic complex is highly fractured and has probably developed a closed groundwater circulation system which may be confined by the relatively less fractured and therefore less permeable granitics. Circulation of groundwater to a depth of from 500 to 1000 meters $(1640.5$ to $32.81 \mathrm{ft}$ ) within the syncline is all that would be necessary to account for the Easy Going Warm Spring $(19.9 \mathrm{C} ; 67.8 \mathrm{~F})$ and could also account for the slightly heated waters of the Gable Creek spring $(13.4 \mathrm{C} ; 56.1 \mathrm{~F})$. Heating of snowmelt water, originally at about $5 \mathrm{C}(41 \mathrm{~F})$, infiltrated higher on the surrounding massif through direct circulation to the Easy Going Cold Spring would account for the 7.6C (45.7F) temperature observed.

\subsubsection{Conclusion}

Based on a geothermal gradient of $15 \mathrm{C} / \mathrm{km}(43.5 \mathrm{~F} / \mathrm{mi})$, economic resource temperatures for utilization at the Pine Creek Mine would require drilling to a depth in excess of 5.7 kilometers $(18,700 \mathrm{ft}$ ) and would probably encounter dry rock. A specific reservoir confirmation plan is outlined in Appendix $B$. 


\section{REFERENCES}

Bateman, P.C. 1956, Economic Geology of the Bishop Tungsten District, California: California Division of Mines, Special Report 47.

Bateman, P.C., 1965, Geology and Tungsten Mineralization of the Bishop District, California: U.S. Geology Survey, Professional Paper 470.

Brewer, G., 1979, Personal Communication: Senior Environmental Engineer, Union Carbide Corporation-Metals Division's Pine Creek Operations.

Bryan, K., 1919, Classification of Springs, The Journal of Geology, v.27, P.522-561.

California, State of, Department of Water Resources, undated, Water Data Information System (WDIS): Sacramento, California.

California, State of, Department of Water Resources, 1972, Hydrologic Data:1970, Part V: Southern California: Bulletin 130-70, p.399.

Craig, H., 1961a, Standard for Reporting Concentrations of Deuterium and Oxygen-18 in Natural Waters: Science, v.133, p.1833-1834.

Craig, H., 1961b, Isotopic Variations in Meteoric Waters: Science, v.133, p.1702-1703.

Craig, H., 1967, The Isotopic Geochemistry of Water and Carbon in Geothermal Areas: in Nuclear Processes in Geologic Settings: National Research Council Commission of Nuclear Science, National Science Series Report 19, p.17-53.

Feth, J.H., C.E. Roberson, and W.L. Polzer, 1964, Sources of Mineral Constituents in Water from Granitic Rocks, Sierra Nevada, California and Nevada: U.S. Geological Survey, Water Supply Paper, 1535-I.

Fournier, R.O., 1979, A Revised Equation for the Na/K Geothermometer: Geothermal Resources Council, Transactions, v.3, p.221-224.

Fournier, R.O., 1977, Chemical Geothermometers and Mixing Models for Geothermal Systems: Geothermics, v.5, p.41-50.

Fournier, R.O., 1973, Silica in Thermal Waters: Laboratory and Field Investigations: in J.W. Clarke ed., Proc. Inter. Symposium on Hydrogeochemistry and Biogeochemistry, Japan, 1970, p.122-139.

Fournier, R.O., and R.W. Potter, II, 1978, A Magnesium Correction for the Na-K-Ca Chemical Geothermometer: U.S. Geological Survey, Open-File Report 78-986.

Fournier, R.O., and J.J. Rowe, 1966, Estimation of Underground Temperatures from the Silica Content of Water from Hot Springs and Wet-Stream Wells: American Journal of Science, v.264, p.685-697. 
Fournier, R.O., and A.H. Truesdell, 1973, An Empirical Na-K-Ca Geothermometer for Natural Waters: Geochimica et Cosmochimica Acta, v.37, p.1255-1275.

Fournier, R.O., and A.H. Truesdell, A.H. Truesdell, 1974, Geochemical Indicators of Subsurface Temperature-Part II, Estimation of Temperature and Fraction of Hot Water Mixed with Cold Water: Journal Research, U.S. Geological Survey, v.2, p.263-270.

Fournier, R.O., D.E. White, and A.H. Truesdell, 1974, Geochemical Indicators of Subsurface Temperature-Part I, Basic Assumptions: Journal Research, U.S. Geological Survey, v.2, p.259-262.

Friedman, I., and G.I. Smith, 1970, Deuterium Content of Snow Cores from Sierra Nevada Area: Science, v.468, p.467-470.

Friedman, I., and G.I. Smith, 1972, Deuterium Content of Snow as an Index to Winter Climate in the Sierra Nevada Area: Science, v.176, p.790-793.

Goguel, J., 1976, Geothermics: McGraw-Hill Book Company, New York.

Lachenbruch, A.H., 1968, Preliminary Geothermal Model of the Sierra Nevada: Journal of Geophysical Research, v.73, p.6977-6989.

Lachenbruch, A.H., J.H. Sass, R.Y. Munroe, and T.H. Mosesm, Jr., 1976, Geothermal Setting and.Simple Heat Conduction Models for the Long Valley Caldera: Journal of Geophysical Research, v.81, p.769-784.

Leventhal, J.S., and W.F. Libby, 1970, Tritium Fallout in the Pacific United States: Journal of Geophysical Research: v.36, p.7628-7633.

Mariner, R.H., T.S. Presser, and W.C. Evans, 1977, Hot Springs of the Central Sierra Nevada, California: U.S. Geological Survey, Open-File Report 77-559.

Muffler, L.J.P., editor, 1979, Assessment of Geothermal Resources of the United States - 1978: U.S. Geological Survey, Circular 790.

National Oceanographic and Atmospheric Administration, 1977, Geothermal Energy Resources of the Western United States: Environmental Data Service.

Paces, T., 1978, A Systematic Deviation from Na-K-Ca Geothermometer Below 75C and Above 10-4 atm $\mathrm{P}_{\mathrm{CO}_{2}}$ : Geochimica et Cosmochimica Acta, v.39, p.541-544.

Pakiser, L.C., and M.F. Kane, 1965, Gravity Study of the Owens Valley; in Geology and Tungsten Mineralization of the Bishop District, California by P.C. Bateman: U.S. Geological Survey; Professional Paper 470, p.191-195.

Pakiser, L.C., M.F. Kane, and W.H. Jackson, 1964, Structural Geology and Volcanism of Owens Valley Region, California - A Geophysical Study: U.S. Geological Survey, Professional Paper 438. 
Piper, A.M., 1944, A Graphic Procedure in the Geochemical Interpretation of Water Analyses: Translation of the Geophysical Union, v.25, p.914-928.

Pitt, A.M., and D.W. Steeples, 1975, Microearthquakes in the Mono Lake-Northern Owens Valley, California, Region from September 28 to October 18, 1970: Bulletin of the Seismological Society of America, v.65, p.835-844.

Posner, R.H., 1979, Personal Communication: Senior Mine Geologist, Union Carbide Corporation-Metals Division's Pine Creek Operations.

Putnum, W.C., 1960, Origin of Rock Creek and Owens River Gorges, Mono County, California: University of California Publications in Geological Sciences, v.34, p.221-280.

Rinehart, C.D., and D.C. Ross, 1956, Economic Geology of the Casa Diablo Mountain Quadrangle, California: California Division of Mines, Special Report 48.

Rwoan, K., 1979, Personal Communication: Senior Clerk, Union Carbide CorporationMetals Division's Pine Creek Operations.

Sheridan, M.F., 1975, The Mineralogy and Petrology of the Bishop Tuff: Ph.D. thesis, Stanford University, Stanford, California, 165p.

Sorey, M.L., R.E. Lewis, and F.H. Olmsted, 1978, The Hydrothermal System of Long Valley Caldera, California: U.S. Geological Survey, Professional Paper 1044-A.

Steeples, D.W., and A.M. Pitt, 1976, Microearthquakes In and Near Long Valley, California: Journal of Geophysical Research: v.81, p.841-847.

Truesdell, A.H., and R.O. Fournier, 1977, Procedure for Estimating the Temperature of a Hot-Water Component in a Mixed Water by Using a Plot of Dissolved Silica Versus Enthalpy: Journal Research, U.S. Geological Survey, v.5, p.49-52.

Willey, L.M., J.R. O'Neil, and J.B. Rapp, 1974, Chemistry of Thermal Waters in Long Valley, Mono County, California: U.S. Geological Survey, Open-File Report 74-1125.

Wollenberg, H.A., and A.R. Smith, 1968, Radiogeologic Studies in the Central Part of the Sierra Nevada Batholith, California: Journal of Geophysical Research, v.73, p.1418-1495.

Wollenberg, H.A., and A.R. Smith, 1970, Radiogenic Heat Production in Prebatholithic Rocks of the Central Sierra Nevada: Journal of Geophysical Research, v.75, p.431-438. 


\section{SECTION 6}

\section{INSTITUTIONAL BARRIERS ASSESSMENT}

\subsection{INTRODUCTION}

As a part of the contract effort, a preliminary search of literature concerning potential institutional barriers to geothermal development in Inyo County was conducted. Regulations of this county were selected as pertinent to the initial review because the site of the potential geothermal application, the tungsten processing facility of Union Carbide at Pine Creek, is located in Inyo County.

Based on the literature search, governmental controls over geothermal exploration at the Union Carbide-Metals Division facility site near Bishop, California are described in this section. The following assumptions were made for this description:

1. All geothermal exploratory drilling will take place on the site of the existing mill.

2. The purpose of the proposed project will be to extract hydrothermal fluid for direct heat applications at the mill site.

3. The temperature of the hydrothermal fluid at the wellhead is expected to be approximately $250 \mathrm{~F}$.

4. No surface use of land beyond the site where the mill is located is anticipated, with one possible exception involving the use of existing pipeline and tailings ponds.

To determine which governmental controls Union Carbide must comply with if it decides to initiate geothermal exploration at the mill site, it was first necessary to determine the ownership of the surface and mineral estates at the site. It was concluded that the patents which Union Carbide presently hold would in all probability allow it to explore for geothermal resources at the site without acquiring a federal geothermal lease or any additional private ownership rights.

Governmental controls with which Union Carbide must comply are those of the California Division of Oil and Gas, the California Environmental Quality Act, the Regional Water Quality Control Board, the Air Pollution Control District, and the Geothermal Ordinance of Inyo County.

The last of these controls, the Geothermal Ordinance, was enacted to ensure local control over geothermal development within unincorporated portions of Inyo County. Entitled the "Geothermal Ordinance of the County of Inyo" (Inyo County, 1974), it is patterned after the ordinance in effect in Imperial County, California (Imperial County, 1971). It is supplementary to regulations governing conditional use permits, i.e., an applicant must comply with all conditional use permitting requirements in addition to those imposed by the Geothermal Ordinance. The ordinance is composed of seven chapters, the first stating the general purpose and intent of the law. Salient points of the remaining six chapters are discussed in Section 6.4.1.5 et seg. 
Approximately 90 percent of the land in Inyo County is managed by the federal government under the U.S. Forest Service and the Bureau of Land Management (BLM). Therefore, the issue of the interface between local government and federal government in geothermal resource development on federal lands is raised. The federal government takes the not too surprising position that local government has no regulatory permitting authority over lands under its jurisdiction. Inyo County, on the other hand, takes the position that federal, state, and private lands all fall within its regulatory jurisdiction (Jet Propulsion Laboratory, 1976). Thus, local regulations, such as the geothermal ordinance, are arguably applicable. While, as a practical matter, would-be geothermal developers may elect to comply with both federal and local regulations, a needless duplication of effort may result.

Additionally, since the State of California extensively regulates geothermal drilling activities through the Division of Oil and Gas, an argument can be made that a local government's efforts to control this activity through legislation are invalid. An Opinion of the State Attorney General examined whether the state has fully occupied the field of drilling, operating, maintaining and abandoning oil, gas and geothermal wells (59 OP. ATT'Y GEN. 461 (1976)). If the state has fully occupied, i.e., preempted the field, the Inyo County Geothermal Ordinance is void. The Attorney General concluded, however, that the state has not fully occupied the field, except regarding regulation of the underground phases of oil, gas and geothermal activities. The conclusion reached in the Opinion was that local governments may validly regulate the surface activities of geothermal operators.

The Inyo County Geothermal Ordinance is basically a regulatory mechanism directed at surface conditions. The ordinance would probably survive a challenge based on the state preemption issue.

\subsection{OWNERSHIP OF THE RESOURCE}

The Union Carbide tungsten mill at Pine Creek is located within the Inyo National Forest. To determine which governmental controls would apply to a geothermal operator at the mill site, Union Carbide's mineral and surface rights at the mill site and in the immediate surrounding area were researched.

\subsection{1}

Surface and Mineral Rights

Union Carbide's right to occupy the surface estate at the mill site and the areas surrounding it and to conduct mining operations beneath the surface of these same areas is defined by patented mining and mill site claims, unpatented mining claims, and special use permits. A patent is a deed from the federal government which conveys the legal title of public lands to the party to whom the patent is issued. By granting patents to Union Carbide, the United States conveyed away its entire interest in the land. Union Carbide received legal title in fee simple. This title encompasses both the surface and mineral estates.

Union Carbide holds Patent No. 1170240 and Patent No. 1170242, which were granted to it in 1957 by the United States. These patents include the land on 
which the mill is presently located. They contain no reservation of minerals to the United States.

The Bureau of Land Management office at Bishop, California maintains the Union Carbide patent records. These records contain no indication that the federal government reserved any ownership interest in the surface or mineral estates in the land patented to Union Carbide.

The mill site at Pine Creek is surrounded by federally owned land which is part of the Inyo National Forest. If the mill site were located on National Forest land, Union Carbide could explore for and develop geothermal resources at the mill site only after it obtained a federal geothermal lease. The Bureau of Land Management has statutory authority to issue geothermal leases on all federal lands (Geothermal Steam Act of 1970).

Because Union Carbide has fee simple ownership of the surface and mineral estates at the mill site, it need not obtain a federal geothermal lease. Applicable governmental controls will be those imposed by the State of California on geothermal operators drilling on privately owned land within the state. These controls are discussed in Section 6.4.

\subsubsection{Water Rights}

The patents held by Union Carbide contain the following conditions:

That the premises hereby granted shall be held subject to any vested and accrued water rights for mining, agricultural, manufacturing, or other purposes, and rights to ditches and reservoirs used in connection with such water rights, as may be recognized and acknowledged by the local laws, customs, and decisions of the courts.

Los Angeles County holds a power site withdrawal which encompasses the area occupied by the Union Carbide mill complex (Norton, 1980). Other vested water rights in the area may also exist. Numerous issues regarding the relationship between a geothermal resource and surface and subsurface water systems have not been resolved (Olpin \& Tarlock, 1978).

In Geothermal Kineties, Inc. v. Union Oil Co., 75 Cal. App. 3d 56 (1977), a California appellate court determined that ownership of the mineral estate included ownership of geothermal resources. The resource involved was geothermal steam. The evidence in the case convinced the court that the geothermal steam reservoir was completely separate and distinct from the groundwater system. The parties were not litigating water rights; the issue was whether the owner of the surface estate or the mineral estate owned the geothermal steam resource.

In United States v. Union Oil Co. of California, 549 F.2d 1271 (9th Cir. 1977), the Court of Appeals concluded that the federal government's reservation of "all the coal and other minerals" in land patented under the Stock-Raising Homestead Act 
of 1916 encompassed geothermal steam resources. The court rejected the defendant's contention that Congress must not have intended to reserve geothermal resources to the government because homesteaders on the patented lands could drill wells and develop springs. The court distinguished between geothermal resources and surface fresh water supplies. As in the Geothermal Kinetics fact situation, however, the principal issue was whether reserved minerals included geothermal steam resources. Discussion of water rights issues was tangential.

In the Pine Creek fact situation, Union Carbide already owns both the surface and mineral estates at the mill site. The geothermal resource, however, is liquiddominated. Union Carbide's right to use a liquid-dominated resource might be challenged by parties contending that they hold superior water rights.

California law contains a mechanism to assist in resolving this issue. Public Resources Code section 3742.2 provides for issuance of a "certificate of primary purpose" by the Geothermal Resources Board. The board will issue the certificate when it determines that a well which is producing or is capable of producing geothermal resources is primarily for that purpose. The effect of the certificate is to establish a rebuttable presumption that the holder has absolute title to such geothermal resources: No certificate would be issued for a well drilled primarily for the purpose of producing water usable for domestic and irrigation purposes.

\subsubsection{Surface Rights in the Area Surrounding the Mill}

Union Carbide's surface rights on the Forest Service land surrounding the mill site are defined by Special Use Permits issued by the Forest Service. It is anticipated that all geothermal drilling will take place at the mill site. Possible involvement of the surrounding area is contemplated, however, with respect to disposal of cuttings during the drilling operation. One method of disposing of the cuttings would be to use existing pipes which run from the mill to the tailings ponds. These pipes could also be used during production tests of the supply well after well completion. The pipes and ponds are on land occupied by Union Carbide under the Special Use Permits (see Figure 7-9).

The permits indicate that among the uses allowed are those connected with mining, milling, and processing. Surface use contemplated for geothermal purposes is closely related to these specified uses. Since the purpose of all geothermal activity at the mill site would be to obtain geothermal fluid for direct heat application at the mill, disposal of soil displaced by geothermal drilling would likely be "connected with mining, milling, and processing." The United States Forest Service White Mountain District office has informally concluded that no additional Special Use Permit would be required, although rewriting the existing permits specifically to authorize geothermai surface use might be appropriate (Norton, 1980).

PERMITS REQUIRED FOR GEOTHERMAL EXPLORATION AT THE EXISTING MILL SITE

If it is assumed that Union Carbide, by virtue of the patents it holds at the existing mill site, is the owner of private land within the State of California, the corporation must comply with requirements imposed by state and county governments 
on geothermal operators. Union Carbide must obtain approval of a Notice of Intention to Drill (NOI) from the State Division of Oil and Gas (DOG) and also comply with the requirements of the Regional Water Quality Control Board, the local Air Pollution Control District, and Inyo County.

\subsubsection{California Division of Oil and Gas}

\subsubsection{Drilling Requirements}

Prior to drilling a geothermal well at the mill site, Union Carbide must file a Notice of Intention to Drill (NOI) with the State Oil and Gas Supervisor or the District Director (CAL. PUB. RES. CODE $\$ 3724$ ). A fee of $\$ 1,000$ is required for drilling an exploratory well of 1000 feet or greater. An additional fee up to a maximum of $\$ 1,000$ may be assessed for drilling in areas of unstable terrain (Stockton, 1979). The mill site area might be considered an area of unstable terrain by the DOG due to a series of earthquakes occurring in the spring of 1980.

The State Oil and Gas Supervisor or District Director must respond within ten working days in writing to an application for approval of an NOI. Failure to respond within the ten day limit is treated as approval of the program.

A $\$ 25,000$ individual indemnity bond is required for the drilling, redrilling, deepening, maintaining, or abandoning of any well. This bond is filed along with the NOI. The operator has the option to file a single bond of $\$ 100,000$ to cover all of the filer's operations in the state.

Although less costly bond requirements (CAL. PUB. RES. CODE § 3725.5) are imposed on operators of low temperature wells, as defined in Public Resources Code section 3703.1, the well proposed for the mill site at Pine Creek would not be classified as low temperature. For purposes of the statutory definition of a "low-temperature geothermal well," the temperature of the fluid from the resource must be no greater than the boiling point of water at the altitude of occurrence. The estimated boiling point of water at the altitude of the Pine Creek site, about 7800 feet, is $195 \mathrm{~F}$. The estimated temperature of the geothermal resource at Pine Creek is 250F.

\subsubsection{Environmental Requirements}

Receipt by the DOG of an application for approval of an NOI triggers the need for the DOG to comply with the provisions of the California Environmental Quality Act (CEQA). The Act applies to situations in which a public agency proposes to approve a discretionary project (CAL. PUB. RES. CODE § 21080(a)). Assembly Bill No. 2644, enacted in 1978, designated the DOG "lead agency" for purposes of CEQA for any "geothermal exploratory project" (CAL. PUB. RES. CODE \$3715.5). The term "geothermal exploratory project," defined in section 21056.6 of the Public Resources Code, means a project of no more than six wells which is chiefly undertaken to evaluate the presence and characteristics of geothermal resources before beginning development. The project must be located at least one-half mile from geothermal development wells which are capable of producing geothermal resources in commercial quantities. The proposed exploratory drilling at the mill site, if confined to six or fewer wells, would fit within this definition. No geothermal development wells are located within one-half mile of the mill site. 
DOG may delegate its lead agency responsibility to a county which has adopted a geothermal element for its general plan. Imperial County, however, is the only county which has adopted a geothermal element thus far. As discussed in Section 7.3 of this report, a joint geothermal element is being prepared for Mono and Inyo Counties. DOG could elect to delegate its lead agency responsibilities regarding geothermal exploration at the Pine Creek site to Inyo County upon completion of the joint geothermal element by the two counties.

Assembly Bill No. 2644 also imposes a time limit on the "lead agency," whether it is the DOG or a county to which the DOG has delegated these responsibilities. The lead agency must complete its responsibilities under CEQA within 135 days of receipt of a completed application for a geothermal exploratory project (CAL. PUB. RES. CODE 83715.5$)$. This statutory time limit was designed to expedite geothermal exploration. Prior to passage of Assembly Bill No. 2644, processing of environmental impact reports had taken up to one year (Nevis, 1979).

\subsubsection{The Regional Water Quality Control Board}

The mill site at Pine Creek is under the jurisdiction of the Lahontan Region of the California Regional Water Quality Control Board. This agency administers the federal Water Pollution Control Act and the state Water Quality Control Act. Before beginning geothermal drilling, an operator must obtain from the Board an order entitled "Waste Discharge Requirements" which will specify detailed conditions pertinent to the project.

Copies of waste discharge requirements imposed on geothermal testing operators in Lahontan Region were obtained. Orders formulated in the $1960 \mathrm{~s}$, which have subsequently been rescinded, specified types and amounts of various chemicals which the operator could discharge into designated areas. Currently valid orders are less detailed in nature, tending to indicate instead where existing water quality must be preserved. An operator must also comply with monitoring and reporting requirements.

\subsubsection{The Air Pollution Control District}

The Great Basin Unified Air Pollution Control District has jurisdiction over the Pine Creek mill site. This local agency administers the requirements of the State Air Resources Board. A geothermal operator must obtain an Authority to Construct and a Permit to Operate. Although several parties have begun the application process regarding geothermal drilling in the Great Basin District, no Authority to Construct or Permit to Operate has been issued thus far for a geothermal drilling project (Fryxell, 1980).

\subsubsection{The Geothermal Ordinance of Inyo County}

Before any geothermal exploratory project may be carried out in the unincorporated areas of Inyo County, a conditional use permit must be obtained from the County' Planning Commission. This requirement is imposed by the Geothermal Ordinance of the County of Inyo (Ord. $239 \$ 1.20$ (1973)) which is analyzed in detail in the following subsections. 


\subsubsection{Definitions Under the Ordinance}

A distinction is drawn between a geothermal exploratory and a geothermal production project. The former encompasses minor surface-disturbing activities ranging from geological, geophysical studies and surveys to observation and exploratory wells to temporary test facilities. An observation well is one utilized strictly for temperature monitoring purposes, not exceeding four inches in diameter and drilled no deeper than 500 feet.

A geothermal production project encompasses those activities which will result in construction of permanent structures and significant alteration to the landscape (Ord. 239 53.25). Interestingly, the definition of a geothermal well includes previously abandoned wells so that presumably a conditional use permit would be required before utilizing these wells again.

\subsubsection{Unlawful Acts}

This chapter (Ch. 19.12) simply states that no geothermal activity can be carried on without first obtaining a conditional use permit from the county and without complying with all applicable local, state, and federal laws and regulations.

\subsubsection{8 $\quad \underline{\text { Permits }}$}

Chapter 19.16 specifies those items which must be contained in an application for a geothermal exploration project and for a production project. This regulation requires the applicant to submit proof of project approval by the State Division of Oil and Gas as well as approval by the county health department and regional water quality control board. Setting out requirements which address specific concerns associated with geothermal exploration and development appears to have three distinct advantages over the conventional conditional use application: (1) it assists the County Planning Commission in evaluating a particular project; (2) it potentially eliminates the need for an applicant to respond to non-germane questions; and (3) it advises an applicant as to those other agencies she or he must contact before securing final approval.

Once the application for a particular project has been satisfactorily completed, the matter is scheduled for hearing before the Planning Commission. This body is the final arbiter on the decision whether to issue a permit. All permits are issued contingent upon acceptance of any additional requirements imposed by the Planning Commission and of the conditions set forth below.

\subsubsection{9 $\quad$ Conditions}

The conditions outlined in Chapter 19.20 of the Inyo Geothermal Ordinance fall within two basic categories: environmental concerns and the general "terms and conditions" to development. Under the first category, potential environmental impacts in the areas of waste disposal, noise, air pollution, aesthetics, and land use are noted. With respect to land use, as in Imperial County, the applicant requesting project approval must make an effort to minimize the effect of geothermal development on the all-important agricultural use of land. In addition, the applicant/operator is required to participate in any subsidence and earth movement prevention and detection program in effect. 
Under the second category, the general terms and conditions associated with an Inyo County geothermal project primarily involve bonding and insurance requirements. The provision dealing with bonding requirements follows a similar provision found in the Imperial County Ordinance. It requires the operator of any well or production project to file a $\$ 50,000$ indemnity bond for each well drilled or for any abandoned well re-entered. The purpose of requiring a bond is to ensure that Inyo County will be reimbursed for any costs incurred in repairing damage caused by a geothermal operator. The Inyo County indemnity bond requirement does not exempt the applicant from filing a similar bond required by the State of California Division of Oil and Gas for the protection of the state. The bonding requirements differ, however, in that the State of California imposes only a $\$ 25,000$ per well bond and allows a blanket bond of $\$ 100,000$ to be submitted which covers all of an applicant's well operations (CAL. PUB. RES. CODE $\$ 3728$ (1975)). The Imperial County Geothermal Ordinance provides for a similar blanket bond. State regulations also permit a cash bond to be filed in lieu of an indemnity bond (CAL. PUB. RES. CODE § 3728.5 (1975)). Eliminating this duplication of bonding requirements by designating the county or state as the responsible agency is seemingly one institutional barrier which may be overcome by joint cooperation between the State of California and Inyo County officials.

A second important condition for permit compliance is insurance of a different type. Section 19.20.070 of the Ordinance requires the applicant to submit evidence of insurability against liability in tort arising from geothermal activities for a

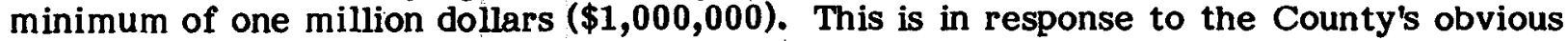
interest in seeing that an operator has adequate coverage to reimburse anyone who has been injured or whose property has been damaged as a result of geothermal operations.

Finally, this chapter requires an operator to supply data (excluding proprietary information) which will assist the County in the development of a Geothermal Element to the Inyo County General Plan. IMAGE, a regional body which includes both Inyo and Mono Counties, was awarded a grant to develop a Geothermal Element and has begun work on the project.

\subsubsection{Standards}

Under the Inyo County Ordinance, standards applicable to geothermal projects are broken down into planning, drilling, and production categories. The following paragraphs describe these standards.

\subsubsection{Planning Standards}

Planning standards relate to siting geothermal wells to minimize the impact of drilling on agricultural land and to prevent any interference with irrigation and drainage patterns. The applicant is required to site wells at specified minimum distances from designated categories of development, such as residences (500 ft) and schools $(2640 \mathrm{ft})$. On the site itself, sumps and ponds must be designed and constructed in accordance with prescribed minimum criteria under the supervision of a registered civil engineer. Before beginning any construction, the operator must submit a soils investigation report for approval. 


\subsubsection{Drilling Standards}

These standards relate primarily to drillsite conditions. The standards imposed by the Inyo County Geothermal Ordinance generally do not affect the drilling program, which is regulated by either the state or federal government, depending on which entity has jurisdiction over the land surface at the drilling site.

One set of standards establishes noise level curves. The Planning Commission determines which differing noise level limits will apply to a particular project. Noise levels are measured at the parcel boundary and not at the nearest sensitive receptor. In addition, site preparation, equipment removal or delivery, and racking up of drillpipe are generally restricted to daylight hours (7 a.m. to 7.p.m.) in order to mitigate noise impacts.

A second set of standards details reporting requirements which are filed with the county surveyor for the subsidence and earth movement detection programs (required under $\$ 19.20 .080$ ).

Finally, the most unusual aspect of the Inyo County Geothermal Ordinance is a requirement that the operator participate in a hot springs protection program. Unfortunately, the Ordinance does not define the term "hot spring." This lack of definition is particularly crucial vis-a-vis the Pine Creek mine operation. To date, two sites, one inside the mine, the other nearby, have been identified for this study as having potential for geothermal resource development because of their proximity to warmer than average springs (see Section 5.3.1). If these springs are considered "hot," and if the identified sites are ultimately selected, compliance with Inyo County's program will be mandatory.

Since the Ordinance fails to give an explicit definition, a literature search of definitions of "hot springs" was undertaken. A Geological Survey report (Waring, 1965) states that, strictly construed, any spring with an average temperature noticeably above the mean annual temperature of the air at the same locality qualifies as thermal or hot. A more restrictive interpretation appears in European sources which classify only those springs having temperatures higher than about $20 \mathrm{C}$ as commercially exploitable. The generally accepted standard of a thermal spring in the United States is a spring the temperature of which is at least $15 \mathrm{~F}$ above the mean annual ambient te mperature at its locality.

The annual ambient temperature in and around the Pine Creek mine facility is approximately 60F. The temperature of the water at the two sites identified is roughly $68 \mathrm{~F}$. Therefore, these springs would be classified as thermal under the first, more liberal definition, but would not qualify under either of the latter definitions.

Assuming the hot springs program is applicable to a project, the Ordinance provides that the operator must locate all known or possible hot springs in the project vicinity, file reports and maps detailing specified information about the springs and monitor the springs at specified time intervals. A further program to return the springs to their "original state" is mandated in the event there is a determination of permanent adverse effects. 
The literature search for institutional barriers also uncovered a state measure proposed for the protection of hot springs. Thermal springs are defined as "any natural or artificial spring outlet whose average temperature is at least $15 \mathrm{~F}$ above the mean annual temperature of the air at the same locality." Assembly Bill No. 1219 (Egeland) introduced in the California Legislature on March 23, 1979, provides for the "protection of naturally occurring thermal springs from the adverse effects of geothermal resources." The stated purpose of the bill is twofold:

To require the State Oil and Gas Supervisor,

a. to grant geothermal development permits only when there is demonstrable evidence that such development would not adversely affect the integrity of significant thermal springs; and

b. to prohibit the granting of such permits under specified circumstances.

To require the Department of Conservation to identify those thermal springs of importance and to conduct a survey with recommended actions of the kinds of activities which could impair the present use and integrity of such springs.

The bill, which would amend Division 3 of the Public Resources Code relating to geothermal resources, was referred to the Committee on Resources, Land Use and Energy for consideration. In November 1979, the Committee dropped this proposal from further consideration and the bill, as presently written, has not been reintroduced in the 1980 session. Nevertheless, it points out a potential institutional consideration/constraint related to regulatory compliance and evidence of some concern in the environmental community that geothermal development should not invariably proceed at the expense of detrimentally affecting significant hot springs.

\subsection{SUMMARY AND CONCLUSION}

A review of institutional barriers which a geothermal operator in Inyo County might encounter was undertaken. The literature search did not uncover a great deal of information pertaining to institutional barriers. This may be due, in part, to the lack of geothermal development in this county to date. Nevertheless, an examination of potential institutional barriers which Union Carbide would encounter if it were to engage in geothermal exploration at the tungsten mill site at Pine Creek in Inyo County was conducted.

Ownership of the surface and mineral estates was researched. Following a determination that Union Carbide is the fee simple owner of the surface and mineral estates on which the mill is presently located, requirements imposed by state and local governments upon geothermal exploration on private land in California were discussed. It was concluded that to drill a geothermal exploratory well in Inyo County, an operator must obtain a Notice of Intention to Drill from the DOG, a Waste Discharge Requirement from the regional Water Quality Control Board, an Authority to Construct and Permit to Operate from the Air Pollution Control District, and a Conditional Use Permit from Inyo County. 
In order to secure a Conditional Use Permit, an applicant must comply with a geothermal ordinance adopted by the county. The "Geothermal Ordinance of the County of Inyo" is patterned after the County of Imperial's "Terms and Conditions for Initial Geothermal Development." The major distinction between these two ordinances is the Inyo County provision which requires identification and protection of hot springs. It was noted, however, that no definition of the term "hot spring" is included in the Ordinance. Therefore, an investigation was made into definitions given the term by other authorities, including one contained in a recent legislative proposal introduced in the State of California Assembly. This investigation was undertaken to determine whether two springs near potential geothermal sites identified for the Bishop-Pine Creek operation fall within the mandate of the Inyo County Ordinance. It was concluded that, under two of the three definitions given, compliance would not be required (see Section 6.4.1.12).

Finally, potential jurisdictional conflicts resulting from a geothermal operators' at tempts to comply with regulations issued by the local, state and federal government are discussed. The federal government, which regulates geothermal drilling on federally-owned land, is the principal land owner in Inyo County. The State of California imposes its requirements on geothermal activities located on state-owned or private land. Inyo County, however, asserts jurisdiction, through its Geothermal Ordinance, over geothermal activities occurring on land owned by the federal or state government or by a private party if the land is located in the unincorporated area of the county.

The issue raised is whether federal and/or state law would preempt controls imposed by a local governmental entity on geothermal activity. It was concluded that the Inyo County Geothermal Ordinance would not, in all likelihood, withstand a challenge based on its applicability to geothermal activities occurring on federal lands within the county. However, the Ordinance might survive a challenge that the State of California has preempted the field. The state and local controls are basically complementary, in that the state generally regulates subsurface activities whereas Inyo County imposes its requirements on the operator's surface activities.

Institutional constraints imposed by federal, state and local governments on geothermal operators drilling at the proposed alternate sites in Mono County are analyzed in Section 8 of this report. 


\section{REFERENCES}

59 OP. ATT'Y GEN. 461 (1976).

California Public Resources Code sections 3715.5, 3724, 3725.5, 3728, 3728.5, 21056.6, 21080(a).

Fryxell, Charles-L., 1980, Control Officer, Great Basin Unified Air Pollution Control District, Bishop, Călifornia, telephone communication, June 4.

Geothermal Kinetics, Inc. v. Union Oil Co., 75 Cal. App. 3d 56 (1977).

Geothermal Steam Act of 1970, 30 U S C A. §§ 1001-1025.

Imperial County, Cal., Terms, Conditions, Standards, and Application Procedures for Initial Geothermal Development (May, 1971).

Inyo County, Cal., Ordinance 239, Title 19, Geothermal Resource Development (January 15, 1974).

Jet Propulsion Laboratory, "Geothermal Energy Resources in California Status Report," prepared for Califiornia Energy Resources Conservation and Development Division, June 30,1976 .

Nevis, Patrick, 1979, "What AB 2644 Means for Geothermal Exploratory Projects in California," Geothermal Resources Council Management Survey Course, Nove mber 27-30, San Diego, California.

Norton, Dave, 1980, Mîning Engineer, White Mountain District, U.S. Forest Service, telephone communication, June 10. In Mr. Norton's opinion, the power withdrawal would have no effect on geothermal exploration at the mill site.

Olpin, Owen and Tarlock, A. Dan, 1978, "Water That Is Not Water," 13 Land and Water L. Kev. 391 (1978). This article contains a thorough discussion of the issues involved regarding water rights and geothermal resource development.

Stockton, Douglas, 1979, "Outline of California Division of Oil and Gas Geothermal Regulations and Permitting Procedures," Geothermal Resources Council Management Survey Course, November 27-30, San Diego, California.

United States v. Union Oil Co. of California, 549 F.2d 1271 (9th Cir. 1977).

Waring, Gerald A., "Thermal Springs of the United States and Other Countries of the World," Geological Survey Professional Paper No. 492 (1965). 


\title{
SECTION 7
}

\author{
ENVIRONMENTAL FACTORS
}

\subsection{PRELIMIN ARY ASSESSMENT OF ENVIRONMENTAL DATA BASE}

The first step towards a full assessment of the potential environmental impact of using geothermal resources to run the Pine Creek Mine and mill facilities was a review of the available environmental data base. The methodology involved in the collection and assimilation of information for this report included three phases: (1) literature search, (2) limited field investigation and (3) interviews.

\subsubsection{Literature Search}

The literature search consisted of a review of printed and unprinted documents and maps relating to Pine Creek Canyon and the environmental resources in the region. The literature review included research in numerous areas throughout the State of California: San Diego, Los Angeles, Independence, Sacramento, and in the general Pine Creek/Bishop region.

The results of the literature search were limited in extent and most of the available data addresses the region rather than Pine Creek specifically. A fairly large amount of information is available for the areas farther north within the Forest Service's Mammoth-Mono Planning Unit. That area is both more recreation-oriented and more highly developed than Pine Creek Canyon; consequently, it has a larger data base. Pine Creek Canyon has historically been used almost entirely for mining activities. In recent years, it has served as a trailhead for growing numbers of backpackers traveling in to the wilderness above the canyon, however recreation has not been encouraged in the canyon itself. Since very little expansion of mining activities in Pine Creek Canyon has been proposed since the passage of the National Environmental Protection Act (NEPA) and the California Environmental Quality Act (CEQA) in the early 1970s, environmental surveys and monitoring in the canyon have been minimal.

The most useful document for this study was an environmental survey report prepared by the U.S. Forest Service in 1971 (USDA, 1971). It covered the proposed expansion of the tailings pond for the Pine Creek Mine and mill facilities and provided an introduction to the resources in the area. It also identified some of the sensitive issues involved in further industrial expansion in Pine Creek Canyon and made recommendations for future management.

A number of documents are available on water quality in the region (California, 1965; California, 1964; U.S. Department of Interior, 1979a). The State of California has funded a number of studies because the water coming from Pine Creek and surrounding areas goes in to the Los Angeles aqueduct. In addition, the Bureau of Land Management monitored water quality in Pine Creek Canyon after two spills from the tailings pipelines (U.S. Department of Interior, 1979) and the Union Carbide Corporation keeps its own records (Union Carbide Corporation, 1979a,b). 
Written information on air quality, biological resources, archaeological resources, land use, air quality and geologic hazards in the vicinity of Pine Creek is scarce and largely of a regional nature. There are no known data on the ambient noise levels in Pine Creek Canyon at this time.

\subsubsection{Field Investigation}

The amount of field investigation was kept to a minimum during this phase of the project. Since the only areas flat and large enough to contain potential geothermal wells are in the immediate vicinity of the existing tungsten mill and related facilities, it was not deemed necessary that on-foot site-specific field surveys be conducted. Instead, it is recommended that these be performed on the two selected geothermal sites in a later phase. For the current study, recent color photographs were used extensively as an introduction to Pine Creek Canyon along with numerous maps. The project manager and the geologist/hydrologist visited the project site.

\section{1 .3}

\section{Interviews}

Personal interviews were a particularly important source of data and were quite necessary due to the relative absence of an environmental data base for the area. The following agencies were contacted: U.S. Forest Service, U.S. Bureau of Land Management, University of California at Riverside, California Department of Fish and Game, Great Basin Unified Air Pollution Control District, Great Basin Foundation, California Department of Water Resources, Union Carbide Corporation, and the U.S. Weather Service.

\subsection{ENVIRONMENTAL ASSESSMENT}

The next step towards a full environmental impact assessment of geothermal development in the Pine Creek area was the preparation of an environmental constraints study. This step involved a synthesis of the available literature and interviews. The object of the study was to ascertain any potential significant environmental effects which might result from the use of geothermal resources to operate the tungsten mill and if any significant constraints were found, to develop possible alternative measures to avoid potential environmental effects.

7.2 .1

Water Quality

7.2.1.1

\section{Environmental Setting}

Pine Creek and its tributaries drain a small watershed on the eastern side of the Wheeler Crest within the Sierra Nevada Mountains. The creek has its headwaters in a chain of lakes above 11,000 feet $(3353 \mathrm{~m})$ and flows 15 miles $(24.14 \mathrm{~km})$ to join the Owens River. The Pine Creek Tungsten Mine and mill are located in the eastern end of Pine Creek Canyon; there are three streams in the canyon which are in the vicinity of the Union Carbide facilities. Morgan Creek enters the main canyon from the north above the mine portal and flows past the crushing plant and conveyors to join Pine Creek just below the tungsten mill operations. Pine Creek runs the length of the main canyon in a southeast-northwest orientation and is sometimes dry during a few months of the year when its headwaters are frozen. Gable Creek enters Pine Creek from the 
south side of the main canyon and is east of the Union Carbide mining and mill operations.

The Pine Creek Tungsten Mine is located in the Lahontan Region of the California Regional Water Quality Control Board (RWQCB). The mine has had two spills in recent years, one in 1977 and one in 1978. The first spill, consisted of 300 tons $(272,400 \mathrm{~kg})$ of finely ground rock tailings wastes, resulting in large quantities of sludge in the Avena River. The second spill, consisting of concentrated sulphuric acid, resulted in a large fish and invertebrate kill. An inventory of the Pine Creek area in 1978 also noted that some sediment is being added from the river banks where the road nears the stream (U.S. BLM, 1979). The effects of the tailings ponds have not been thoroughly studied and the proposed project would not affect the ponds. However, at some point, a quantitative analysis of the ponds' impact on water quality should be prepared.

The waters of Pine Creek are currently of excellent quality (Table 7-1) and make up a portion of the water going to the Los Angeles/Owens River Aqueduct. Insignificant levels of contaminants are contributed by mining and milling activities at the Pine Creek Tungsten Mine. The contaminants include: turbidity, total nitrogen, sulfate, sodium, and heavy metals. These are monitored by the RWQCB; contaminant levels are usually below the maximum limit.

Table 7-2 summarizes quarterly total nitrogen and total filterable residue (turbidity) for 1975 through 1977 at three surface water monitoring stations near the Pine Creek Tungsten Mine. The locations of these stations are shown in Figure 7-1. A detailed analysis of the existing water quality in the Pine Creek area is included in Section $V$ of this report.

Union Carbide Corporation currently monitors the three streams in the area (Pine Creek, Gable Creek, and Morgan Creek) every three hours for turbidity and $\mathrm{pH}$ value. In addition, a Union Carbide employee walks the length of the pipeline between the mill and the tailings ponds every two hours looking for possible pipeline breaks or spills. Potential contamination of the watershed is further protected by the placement of concrete trenches beneath the pipelines to contain any spillage. In areas where the collapse of snow drifts might cause a pipeline break, the pipeline is enclosed within special tunnels.

Union Carbide Corporation monitors the three streams monthly for total dissolved solids, sulfate, sodium, ammonia, $\mathrm{pH}$ value, chloride, total nitrates, total filterable residues, tungsten, and molybdenum. Monthly and annual reports are available at the Pine Creek Union Carbide offices. Twice a year the water from Morgan Creek is run into a large tub into which numerous fish are introduced. This test verifies that the clarifier is sufficiently removing the mud.

The quality of geothermal fluids associated with the potential Pine Creek geothermal resource is unknown. It is anticipated that the quality of the resource fluids would be high because of the high quality of the warm spring waters in the mine. 
Table 7-1

PINE CREEK

QUARTERLY RECEIVING WATERS

Total-N \& TFR in $\mathrm{mg} / \mathrm{l}$

\begin{tabular}{|c|c|c|c|c|c|c|}
\hline & \multicolumn{2}{|c|}{$\mathrm{R}-1$} & \multicolumn{2}{|c|}{$\mathrm{R}-3$} & \multicolumn{2}{|c|}{$\mathrm{R}-5$} \\
\hline & $-\mathrm{N}$ & $\overline{\mathrm{TFR}}$ & $-\mathrm{N}$ & TFR & $-\mathrm{N}$ & TFF \\
\hline \multicolumn{7}{|c|}{1975} \\
\hline 1 & 0.80 & 64 & 0.51 & 88 & 1.03 & 396 \\
\hline 2 & 0.32 & 20 & 1.29 & 52 & 1.05 & 200 \\
\hline 3 & 0.38 & 18 & 0.51 & 52 & 0.61 & 272 \\
\hline 4 & 1.01 & 67 & 1.45 & 86 & 0.79 & 286 \\
\hline \multicolumn{7}{|c|}{1976} \\
\hline 1 & NS & NS & 0.72 & 48 & 0.35 & 296 \\
\hline 2 & 0.92 & 16 & 1.89 & 68 & 0.53 & 276 \\
\hline 3 & 0.48 & 4 & 0.57 & 96 & 0.34 & 248 \\
\hline 4 & 1.35 & 39 & 0.50 & 68 & 0.42 & 236 \\
\hline \multicolumn{7}{|c|}{1977} \\
\hline 1 & NS & NS & 0.34 & 82 & 0.36 & 316 \\
\hline 2 & 0.18 & $\begin{array}{c}16 \\
8\end{array}$ & 0.26 & $\begin{array}{l}48 \\
52\end{array}$ & $\begin{array}{l}0.60 \\
0.70\end{array}$ & $\begin{array}{l}185 \\
25 ?\end{array}$ \\
\hline 4 & $\begin{array}{l}0.42 \\
\text { NS }\end{array}$ & NS & 0.34 & 76 & 0.40 & 312 \\
\hline \multicolumn{7}{|c|}{1978} \\
\hline 1 & NS & NS & 0.68 & 96 & 0.75 & 304 \\
\hline 2 & 1.15 & 36 & 1.55 & 80 & 1.69 & 248 \\
\hline 3 & 1.46 & 4 & 0.63 & 24 & 0.91 & 96 \\
\hline 4 & 0.96 & 24 & 1.38 & 92 & 1.14 & 268 \\
\hline \multicolumn{7}{|c|}{1979} \\
\hline 1 & 0.11 & 16 & 0.50 & 72 & 0.64 & 216 \\
\hline 2 & 0.42 & 36 & 0.62 & 84 & 0.51 & 263 \\
\hline 3 & 0.45 & 96 & 1.19 & 76 & 1.07 & 144 \\
\hline 4 & 0.36 & 24 & 0.97 & 72 & 0.50 & 228 \\
\hline
\end{tabular}

$-\mathbf{N}=$ Nitrogen

TFR = Total Filterable Residue

R-1 = Brownstone Bridge

$\mathrm{R}-3=$ Tungstar Bridge

$\mathrm{R}-\mathbf{5}=\mathrm{S}-\mathrm{turn}$

Source: Union Carbide, "Evaluation of Total Filterable Residue and Total -Nitrogen in Bishop Mill Waste Effluent, Receiving Waters and Springs, 1978-79." 
Table 7-2 WATER QUALITY IN PINE CREEK AND A
LOCAL WARM SPRING

\begin{tabular}{ccc}
$\begin{array}{c}\text { Pine Creek } \\
\text { Below }\end{array}$ & 1962 & Easy Going \\
Brownstone Bridge & Drinking & Warm \\
Water Standards & Spring (mg/l) \\
\hline
\end{tabular}

Total Dissolved

Solids (Evaporation)

$\begin{array}{rc}80 & 500^{1} \\ 7.28 & - \\ 0.008 & - \\ 9.0 & - \\ 0-7 & 50^{1} \\ 0-20 & - \\ 7.1 & - \\ <0.1 & 1.0^{2} \\ <0.1 & - \\ <0.3 & 5^{1} \\ <0.1 & 0.05^{1} \\ <0.01 & 0.3^{1} \\ 0.03 & - \\ 0.048 & - \\ 5.0 & - \\ 0.05 & 45^{1} \\ 38 & -1 \\ 38 & 250^{1} \\ 12 & 3.4^{2,3} \\ 1.2 & 250^{1} \\ 2.5 & \end{array}$

10

8.70

pH

$\mathrm{Li}$

$\mathrm{Na}$

K

$\mathrm{Mg}$

$\mathrm{Ca}$

$\mathrm{Sr}$

$\mathrm{Ba}$

Al

Zn

$\mathrm{Mn}$

$\mathrm{Fe}$

B

$\mathrm{SiO}_{2}$

$\mathrm{NH}_{4}$

$\mathrm{NO}_{3}$

$\mathrm{HCO}_{3}$

$\mathrm{SO}_{4}$

F

$\mathrm{Cl}$

NOTES:

1. Recommended limits.

2. Mandatory limits.

3. Varies with temperature.

Source: U.S. Dept. of Public Health, 1962,

Public Health Publication 956, 1962. 


\section{NU $\int_{\text {WESTEC Services, Inc. }}$}

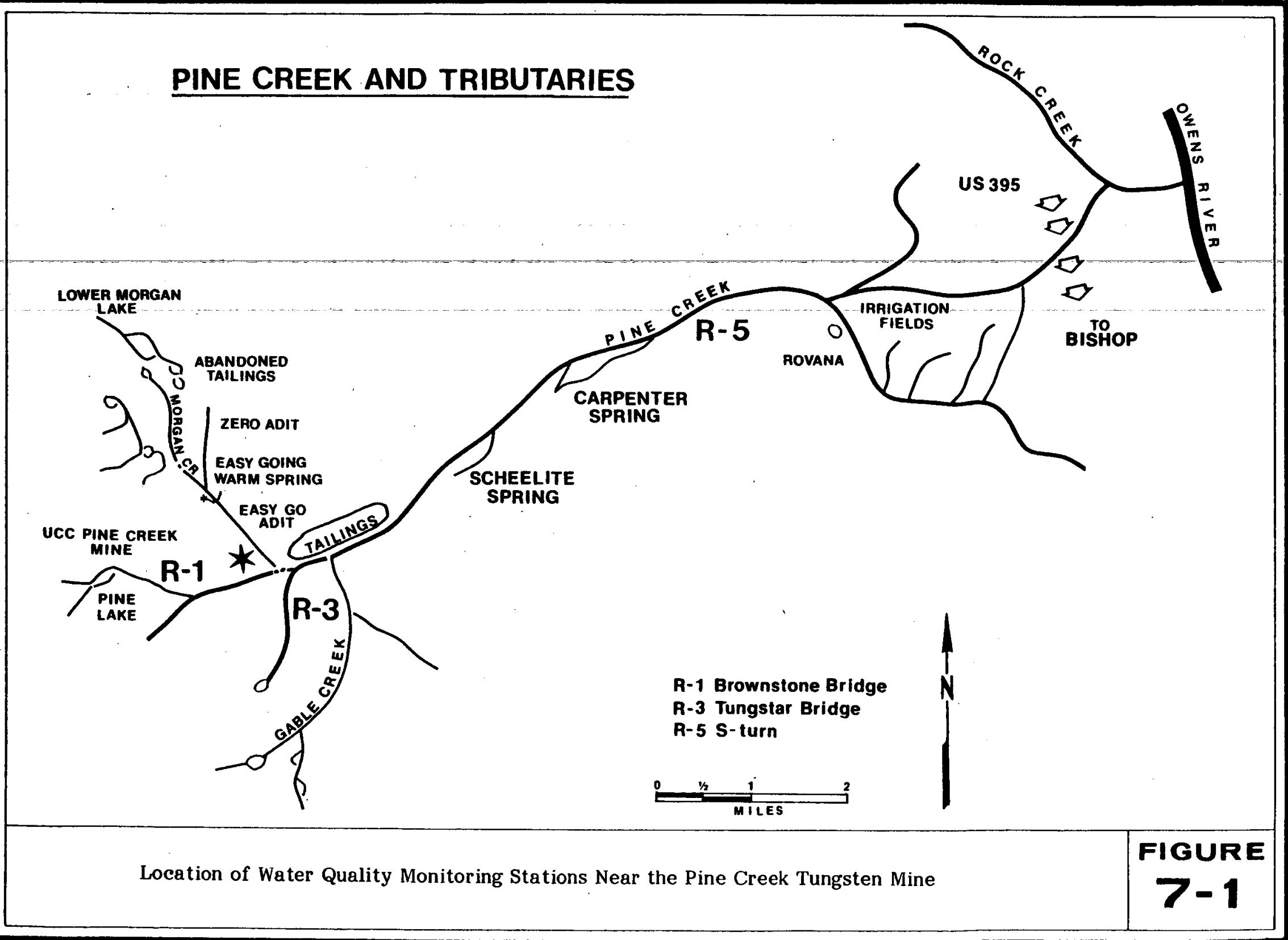




\subsubsection{Potential Impacts/Constraints}

There are no potential water quality impacts which cannot be mitigated or which would act as a constraint to the use of the potential geothermal resource in the area. The identification of potential water quality impacts which could result from use of the potential geothermal resource is dependent upon the chemical characteristics of the geothermal fluid. Since the geothermal fluid characteristics are unknown at the present time, specific potential water quality impacts cannot yet be determined. It is believed that the potential impacts would be similar to those associated with many of the water-dominated geothermal reservoirs: thermal pollution, hydrogen sulfide, heavy metals, etc. All water contaminants are monitored and regulated by the RWQCB.

\subsubsection{Mitigation/Alternatives}

Mitigation of water quality impacts would be brought about by following waste discharge requirements of the RWQCB. The bulk of any dissolved contaminants would be reinjected with the fluid. Minor spills would be the only potential source of input and would be mitigated by cleanup operations, as necessary.

\subsubsection{Biological Resources}

No field work was conducted for the biological constraint analysis. Instead, biologists familiar with the area working for the U.S. Forest Service, California Department of Fish and Game, and the U.S. Bureau of Land Management were interviewed. General familiarity with the study area was accomplished through a large collection of recent photos.

\subsubsection{Environmental Setting}

The Pine Creek Tungsten Mine is situated at an elevation of about 8000 feet along the eastern slope of the High Sierra Crest. The mine is located in a steep-walled valley at the juncture of Pine and Morgan Creeks. The vegetation in the vicinity of the mine within Pine Creek Canyon is expected to be representative of the upper montane-subalpine forest formation (Kuchler, 1977). Predominant species would include Jeffrey pine (Pinus jeffreyi) and fir (Abies sp.). The project area is below alpine forests dominated by lodgepole pine (Pinus contorta var. murrayana) and whitebark pine (Pinus albicaulis) (Rundel et al., 1977). A number of trees on the hillside behind the tungsten mill have died recently, however, the exact cause has not yet been determined. One possibility might be the hydrogen sulfide emitted at the mill (Leys, 1980).

Photographs of the area around the mine show deciduous trees along the creek. These trees are expected to be a combination of willows (Salix spp.), poplar (Populus spp.), and possibly birch (Betula occidentalis). Floral inventories taken farther downstream also indicated the presence of sage (Salvia), alder (Alnus), and Wildrose (Rosa californica) (U.S. BLM, 1979). Much of the area about the mine is very steep and rocky and devoid of trees and shrubs. This includes the tailings ponds down the valley, the areas around them, and the pipeline which carries the tailings. The probable geothermal well sites at the mine are generally flat, previously graded or disturbed areas which are completely devoid of vegetation. 
Numerous sensitive plant species have been recorded in the vicinity of the project area and generally along the east slope of the southern Sierra Crest. Most of these species would not be expected in the area of the Pine Creek Tungsten Mine due to the high amount of disturbed areas, rock type, or habitat type. None of these species are expected in the flat, disturbed areas proposed for well sites. Two plant species which prefer rocky areas and which may be found in the general vicinity of the tungsten mine are Inyo penstemon (Penstemon var. papillatus) and Inyo lomatium (Lomatium rigidum).

The California bighorn sheep (Ovis canadensis californiana) is listed by the California Department of Fish and Game as a rare species. The Wheeler Ridge area was rated as one of the best sites for transplantation of the species, and a portion of one of the two existing herds in the Sierra Nevada was recently introduced into the Mount Morgan-Wheeler Ridge area just northwest of the Pine Creek Tungsten Mine (Stefferude, 1980).

Two mine spills in recent years, one each in 1977 and 1978, have significantly impacted the fauna of the Pine Creek area. The first spill consisted of 300 tons of finely ground rock tailings wastes. The second spill consisted of concentrated sulfuric acid and occurred three weeks after the BLM survey. The latter spill caused a large fish kill which extended down into Round Valley and killed large numbers of invertebrates upstream. The invertebrates were expected to recover quickly, however there haven't been any official field surveys in the area to determine recovery from the spills (U.S. BLM, 1979). Further studies should be conducted to determine the current faunal level before approving any further mine projects upstream.

There are currently two deer herds wintering in the vicinity of Pine Creek Canyon. The Buttermilk-Elderberry and Sherwin herds have a wintering range near Rovana, just northwest of the canyon.

\subsubsection{Potential Impacts/Constraints}

The placement of the geothermal wells and associated processing equipment will not necessitate the loss of any natural habitat areas, as the entire operation will probably utilize existing graded or disturbed zones. No offsite improvements are planned which would necessitate habitat alteration. No rare or endangered species listed by the U.S. Fish and Wildlife Service (USF\&WS, 1979), California Department of Fish and Game (CDF\&G, 1978; 1979), or the California Native Plant Society (CNPS, 1974) are expected to occur at the potential well sites.

The geothermal operation at the site may be expected to produce minor levels of air pollutants; however, these levels are expected to be masked by those fror.. the mine operation and would only occur during the initial well testing phase of the geothermal program. Once the program becomes operational, no emissions are anticipated.

If the geothermal wells are drilled with air instead of drilling mud, as anticipated, there will be no wastes generated during the well testing period. When the wells are put into operation, the geothermal fluids will be reinjected. Water quality will be monitored and regulated by the Regional Water Quality Control Board. Thus, no 
significant water quality-related biological effects are expected from the use of potential geother mal resources in the Pine Creek area.

Noise from geothermal operations will be noticeable during the pad construction and well drilling phases. This potential impact is expected to be both temporary and all or partially masked by the overall mill operation. Once on-line, the geothermal well will not necessitate the occasional expulsion or venting of steam. Such venting has been necessary in some geothermal operations and can adversely affect wildlife.

The proposed geothermal component of the mine is not expected to adversely affect the California bighorn sheep (Ovis canadensis californiana) program currently underway northwest of the mine in the Mount Morgan-Wheeler Ridge area. Nor will the project have an adverse effect on wintering deer herds in the general region.

In summary, it is not expected that there would be any biological constraints on the development and use of two geothermal wells if they are located in the area around the mill and mine operations.

\subsubsection{Mitigation/Alternatives}

Biological concerns with the project as proposed center around air pollutants and water quality. Both of these effects are expected to be very minor, with water quality effects being controlled by the Regional Water Quality Control Board. No specific mitigation measures with regard to biological resources are recommended at this time.

\subsubsection{Noise}

\subsubsection{Environmental Setting}

Noise levels in the general project vicinity reflect the natural forest setting. Ambient noise levels would be expected to be very low. Noise levels around the tungsten mine and mill would be expected to be higher due to general industrial noise, cars, and the initial processing of the rock from the mine (i.e., ore cars and crusher), but would still be relatively low on an average. The potential geothermal well sites are adjacent to the mine and mill operations, and noise levels at the sites would be comparable to those about the mine and mill.

\subsubsection{Potential Impacts/Constraints}

The noise effects from geothermal operations are expected to be temporary and noticeable only during the well drilling phase. Union Carbide employees and travelers entering the adjacent wilderness will be impacted. Once the well is drilled and tested, the geothermal operation will be relatively quiet and will be masked by the noise of the mine and mill. Thus, no long-term adverse noise effects from the geothermal program are anticipated. The proposed process will not necessitate loud releases of steam as is the case in other geothermal resource areas. Thus, no noise constraints on the geothermal operations are expected. 
Aside from standard muffling of drilling equipment, no specific noise abatement recommendations are deemed necessary.

Geological Resources

7.2.4.1 Environmental Setting

The Pine Creek Mine is situated in Pine Creek Canyon, which is carved into the eastern escarpment of the Sierra Nevada Mountains. Operations at the mine produce and process tungsten ore and other minerals from Paleozoic metasedimentary rocks that make up the Wheeler Crest. Wheeler Crest forms a north-south ridge between the main Sierra crest and Round Valley, the northern extension of the Owens Valley, nor thwest of Bishop, California.

The tungsten mill is located on a flat area created through filling a portion of the canyon floor with mine tailings. Natural slopes on bedrock and talus surfaces in the vicinity of the mine are steep, generally considerably in excess of 50 percent. The floor of Pine Creek Canyon is relatively flat and is underlain by Quaternary alluvium. Rockfalls are common from the steep-sided canyons surrounding the mine, resulting in numerous talus cones along the canyon walls. Rockfalls have always been common in Pine Creek Canyon, however, this has not significantly interfered with mine and mill operations (Brewer, 1980).

The nearest active fault to the Pine Creek Tungsten Mine is the Owens Valley fault. This fault is considered capable of generating a maximum credible earthquake of Richter Magnitude 8.25, which at the minimum fault distance of 22 miles $(35.4 \mathrm{~km})$, would result in groundshaking due to bedrock accelerations of about 0.32 gravity (Greensfelder, 1974). Such bedrock accelerations are approximately equivalent to a Modified Mercalli Intensity of VII (Table 7-3). Other active and potentially active faults located within a few miles of the mine include the Sierra Nevada fault zone, the Hilton Creek fault, and several other unnamed faults (Jennings, 1975). These faults were not evaluated by Greensfelder (1974), although a few historic earthquakes are recorded from this area.

\subsubsection{Potential Impacts/Constraints}

Geothermal development at the Pine Creek Tungsten Mine could be impacted by known geologic hazards. The assembly and operation of a rotary drilling $r$ ig in the vicinity of the mine is feasible only on the existing mill pad and on the flats of the bottom of Pine Creek Canyon due to the steep canyon walls. Settlement of the fill which makes up the mill pad is not likely to occur. However, movement of this material, if it were to occur, could shear the well casing.

Potential impacts from a geothermal operation on the canyon floor would be minimal. However, the expected low temperature of the geothermal resource and its distance from the mill may eliminate this location as a viable option. If the canyon floor was used as a site for wells, there would be a potential for flooding along the creek channel. In addition, rockfalls along the canyon walls could pose a problem. 
Table 7-3

THE MERCALLI INTENSITY SCALE

(As modified by Charles F. Richter in 1956 and rearranged,

If most of these effects

are observed

Earthquake shaking not felt But people may observe marginal effects of large distance earthquakes without identifying these effects as earthquake-caused. Among them: trees. structures, liquids. bodies of water sway slowly, or doors swing slowly.

Effect on people: Shaking felt by those at rest. especially if they are indoors. and by those on upper floors.

Effect on people: Felt by most peopie indoors. Some can estimate duration of shaking. But many may not recognize shaking of building as caused by an earthquake: the shaking is like that caused by the passing of light trucks.

Other effects: Hanging objects swing.

Sirucrural effects: Windows or doors rattle. Wooden walls and frames creak.

Effert on people: Felt by everyone indoors. Many estimate duration of shaking. But they still may not recognize it as caused by an earthquake. The shaking is like that caused by the passing of heavy trucks. though sometimes. instead, people may feel the sensation of a jolt, as if a heavy ball had struck the walls.

Other effects: Hanging objects swing. Sianding autos rock. Crockery clashes, dishes ratue of glasses clink.

Sinuctural effects: Doors close, open or swing. Windows rattle.

Effect on people: Felt by everyone indoors and by most people outdonrs. Many now estimate not only the duration of shaking but also its direction and have no doubt as to its cause. Sleepers wakened.

Other effects: Hanging objects swing. Shutters or pictures move. Pendulum clocks stop, start or hange rate. Standing autos tock. Crockery clashes. dishes rattle or glasses clink. Liquids disturbed, some spilled. Small unstable objects displaced or upset.

Sirucrumol effects: Weak plaster and Masonn * crack. Windows break, Doors close, open or swing.

Effect on people: Feit by everyone. Many are frightened and run ourdoors. People walk unsteadily.

Other effects: Small church or schoul bells ring. Pictures thrown off walls. knickinacks and books off shelves. Dishes of glasses broken. Fumiture moved or overtumed. Trees. bushes shaken visibly, or heard to rustle.

Sirucrural effects: Masonry $D^{-1}$ damaged: some cracks in Masonry $C^{*}$. Weak chimneys break at roof line. Plaster, loose bricks, stones, tiles. cornices, unbraced parapets and architectural ornaments fall Concrete irrigation ditches damaged.
If most of these effects

then the are ubserved

Effect on people: Difficult to stand. Shaking noticed by auto drivers.

Orher effects: Waves on ponds; water turbid with mud. Small slides and caving in along sand or gravel banks. Large bells ring. Furniture broken. Hanging objects quiver.

Smuctural effects: Masonry $D^{*}$ heavily damaged: Masonry $C^{*}$ damaged. partially collapses in some cases; some damage to Masonry $8^{*}:$ none some cases; some damage to Masonry $\mathrm{B}^{*}$ : none
to Masonry $\mathrm{A}^{*}$. Stucco and some masonry wails fall. Chimneys, factory stacks, monuments. towers, elevated tanks twist or fall. Frame houses moved on foundations if not bolted down: loose panel walls thrown out. Decsyed piling broken off.

Effect on people: General fright. People thrown to ground.

Orher effects: Changes in flow or temperature of springs and wells. Cracks in wet ground and, on steep slopes. Steering of autos affected. Branches broken from irees.

Structural effects: Masonry $D^{*}$ destroyed: Masonry C* heavily damaged. sometimes with complete collapse; Masonry $B^{*}$ is seriously damaged. General damage to foundations. Frame structures, if not bolted. shifted off foundations.

Frames racked. Reservoirs seriously damaged.

Underground pipes bruken.

Effect on people: General Panic.

Other effects: Conspicuous cracks in ground. In areas of soft ground, sand is ejected through holes and piles up into a simall crater. and, in muddy areas. water fountains are formed.

Sinucturel effects: Most masonry and frame structures destroyed along with their foundations. Some well-built wooden structures and bridges destroyed. Serious damage to dams. dikes and embankments. Railroads bent slightly.

Effect on people: General panic.

Other effects: Large landslides. Water thrown on banks of canals, rivers, lakes. etc. Sand and mud shifted horizontally on beaches and flat and.

Sinucrumel effects: General destruction of buildings. Underground pipetines completely out of service. Railroads bent greatly.

Effect on people: General panic.

Orher effects: Same as for Intensity $X$.

Strucruod effects: Damage nearly total. the ultimate cacastrophe.

Other effects: Large rock masses displaced.

Lines of sight and level distorted. Objects thrown into air.

- Masonry A: Cood workmanship and mortar, rein-

- Masonry B: Good workmanath iesis mortar, rein-

- Masonry C: Good workmanship und mortar, un-

- Mesonar D: reinforced.

wat workmanship and mortar and 
Potential seismic constraints include (1) the potential for groundshaking if a large earthquake were to occur during drilling and (2) possible induced seismicity from fluid reinjection during production level operations. Possible impacts such as subsidence and fault displacement are not considered probable at the Pine Creek Tungsten Mine.

\subsubsection{3}

\section{Mitigation/Alternatives}

Mitigation of potential impacts which have been identified as possible constraints to geothermal development at the Pine Creek Mine can be accomplished through project plan and operation mode. Impacts due to flooding, rockfall, and well casing shear can be minimized by drilling the well in a location that would avoid these problems. One such location is on the floor of Pine Creek Canyon adjacent to the tailings which make up the mill pad.

Earthquake-induced groundshaking is not known to have caused serious problems with drilling rigs in the past, even in the seismically active Imperial Valley. A properly designed and installed rig should be able to withstand the highest probable earthquake event. Seismicity induced by fluid reinjection is a poorly understood phenomena. However, evidence exists that alterations of the injection mode could be made to reduce the impact if induced seismicity should become a problem.

\subsection{5}

Climatology and Air Quality

\subsubsection{1}

\section{Environmental Setting}

The Pine Creek Tungsten Mine is located at the western end of Pine Creek Canyon, on the eastern slope of the Sierra Nevada. It is situated approximately 8000 feet $(2438 \mathrm{~m})$ above mean sea level (MSL), approximately 16 miles $(25.7 \mathrm{~km})$ east of Bishop. The Sierra Nevada Mountains have a major effect on area climate: the mountainous portions receive the greatest amount of rain and snow and snow accumulations vary with exposure, topography and ground cover. The lower slopes and valleys are arid (USDA, 1979a).

Local climatological data is available at the Bishop U.S. Weather Service Office at the Municipal Airport, approximately $2.5(4 \mathrm{~km})$ miles east of Bishop. This data is specific to the Bishop area, which is approximately 16 miles $(25.7 \mathrm{~km})$ and 2000 feet $(610 \mathrm{~m})$ lower in elevation than the project site. During summer and autumn the Mohave Desert, about 150 miles $(241 \mathrm{~km})$ south, causes an early morning and late evening northerly wind; conversely, in the heat of the afternoon it causes a southerly wind that is occasionally strong. Summer skies are usually clear with thunderstorms occurring sporadically from May through August. The days are hot and dry and the nights are cool. The average July temperature in Bishop is $76.6 \mathrm{~F}(24.7 \mathrm{C})$, the average precipitation is 0.17 inch $(0.43 \mathrm{~cm})$, and the relative humidity is 19 percent at $10 \mathrm{a} . \mathrm{m}$. and 14 percent at 4 p.m.

Winter and spring, although seasons of adverse weather in Bishop, are generally mild. Daytime temperatures average in the 50s (Farenheit), with nighttime temperatures in the 20s (Farenheit). The greatest amounts of precipitation occur from November through April. Strong northerly winds are common through February, March, 
and April. It has been reported that east and west winds alternately flow through Pine Creek in summer and fall. In addition, during winter and spring, strong westerly winds flow at higher altitudes over the Sierra Nevada, creating the "Sierra Wave." The average January temperature is $37.1 \mathrm{~F}(2.8 \mathrm{C})$; average rainfall is 1.20 inches $(3.0 \mathrm{~cm})$, and average snow fall of 23.2 inches $(58.9 \mathrm{~cm})$. The relative humidity averages 49 at 10 a.m. and 35 at 4 p.m. (U.S. Department of Commerce, no date).

The National Weather Service has not compiled meteorological data for the Pine Creek Tungsten Mine area. However, because of daily barometer readings at the site conducted by Union Carbide, pressure data is available. The lowest reading for the area is 22.10 inches of mercury $(561 \mathrm{~mm})$, the highest $22.90(582 \mathrm{~mm})$, with an average of $22.60(574 \mathrm{~mm})$ (Brewer, 1980).

The mine operation is located at the head of a box canyon. Therefore, winds generally do not flow over the site in either direction, but instead tend to swirl within the area (Brewer, 1980). Hydrogen sulfide emissions have been observed for distances up and down the canyon (USDA, 1971; Leys, 1980). If the proposed geothermal program is approved, additional hydrogen sulfide monitoring should be conducted prior to and during the geothermal operations. Monitoring should be conducted at varying distances from the mill and mine operations as well as at several locations within the portions of the John Muir Wilderness Area closest to the tungsten mill.

There are two smokestacks in the project area. One emits hydrogen sulfide $\left(\mathrm{H}_{2} \mathrm{~S}\right)$ and carbon dioxide $\left(\mathrm{CO}_{2}\right)$; the other emits primarily sulfur dioxide $\left(\mathrm{SO}_{2}\right)$. Data has been compiled by Union Carbide for 1979 emissions of $\mathrm{H}_{2} \mathrm{~S}$ and $\mathrm{SO}_{2}$ (Figures 7-2 through 7-6). No a mbient air measurements have been conducted for other pollutants, however, it is expected that the amount of all types of emissions from the mill are well below that allowed by state or federal standards (Fryxell, 1980).

Air quality monitoring in the area is provided by the Great Basin Air Pollution Control District located in Bishop. Monitoring of total suspended particulates (TSP) has been conducted from mine locations around the Bishop area; the nearest location to the tungsten mine is in Bishop. This information, including state and federal standards, and days TSP exceed the standards, is found on Tables 7-4 and 7-5.

In addition to TSP, the Great Basin Air Pollution Control District has an ozone monitor in Bishop and a carbon monoxide monitor at Mammoth Lakes. Limited preliminary data from these sites suggest no violations of standards for either station (Fryxell, 1980).

The Pine Creek Tungsten Mine operation is currently entirely dependent on fuel oil for the production of process steam and on electrical energy for prime movers. The processing mill operates 24 hours a day, seven days a week. Operational steam demand is $55,000(24,970 \mathrm{~kg})$ pounds per hour which is presently generated with package boilers utilizing approximately 3.4 million gallons (12.9 million liters) of fuel oil per year. The electrical demand of the facility is approximately 36 million kilowatt hours per year. Measures are available to determine amounts of pollutants emitted into the atmosphere from these sources. If the proposed geothermal program proceeds, current emissions from these sources should be quantified so that an assessment of air impacts can be made at a later date. 


\section{ons}

WESTEC Services, Inc.

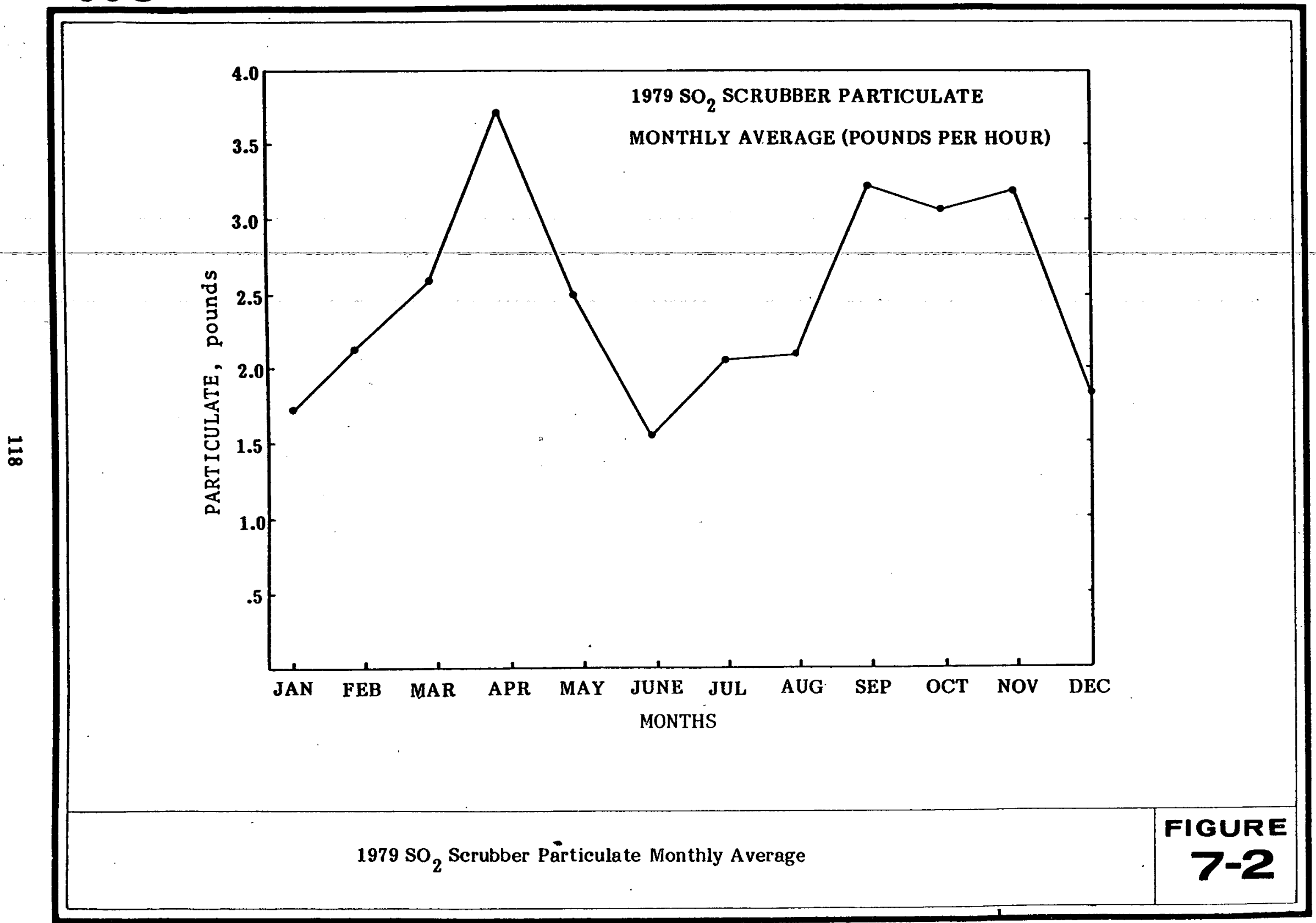




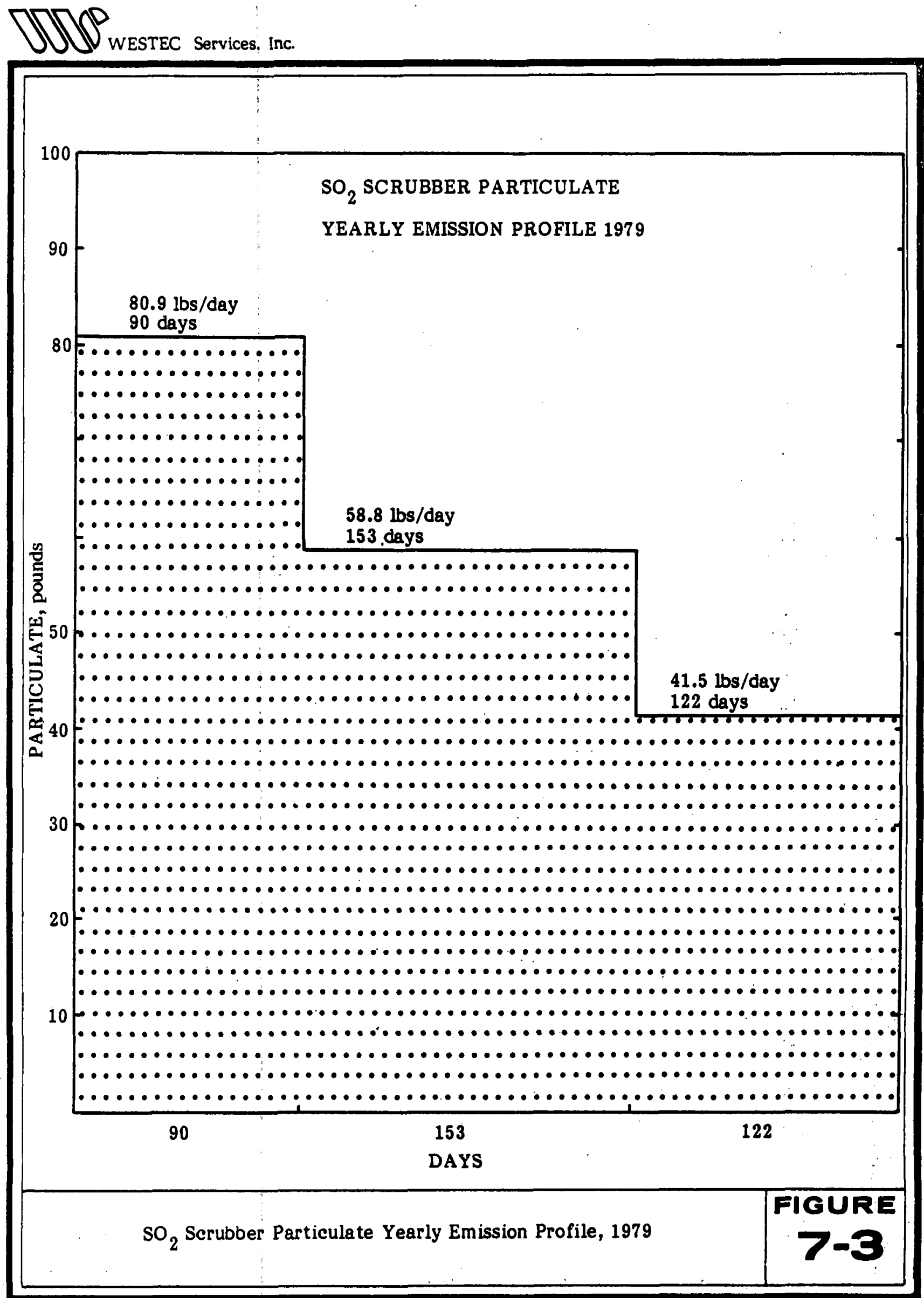



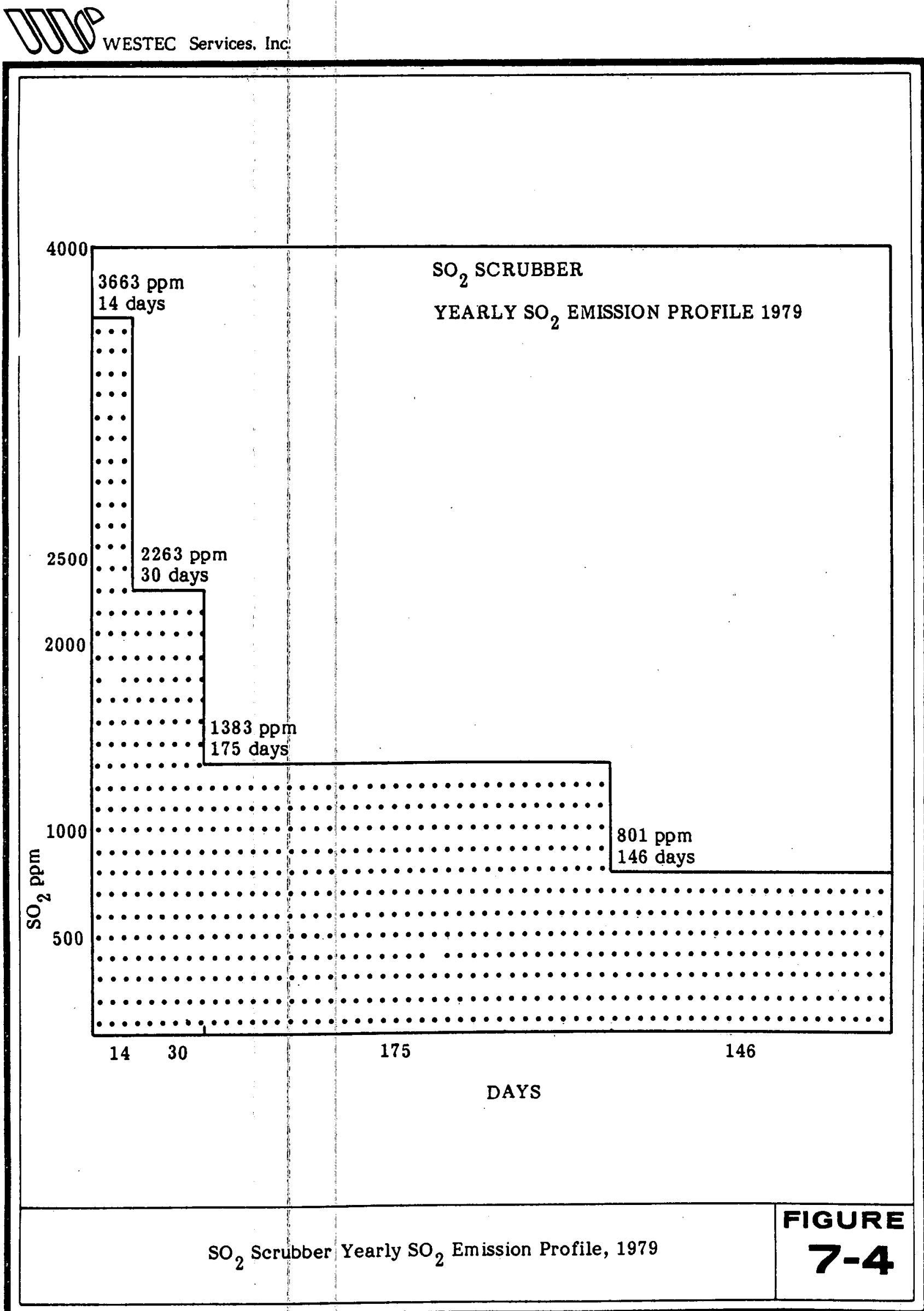


\section{NUN}

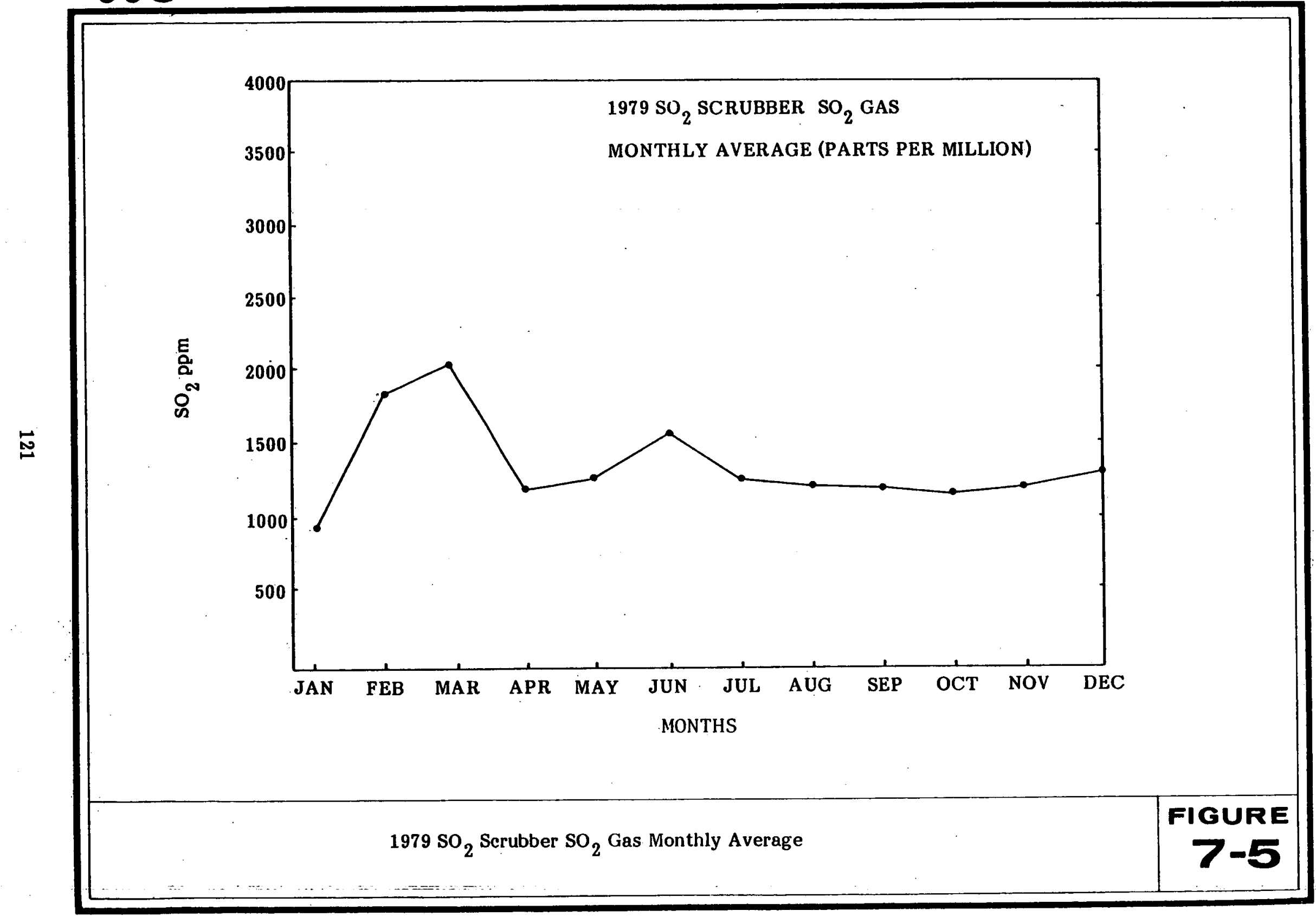




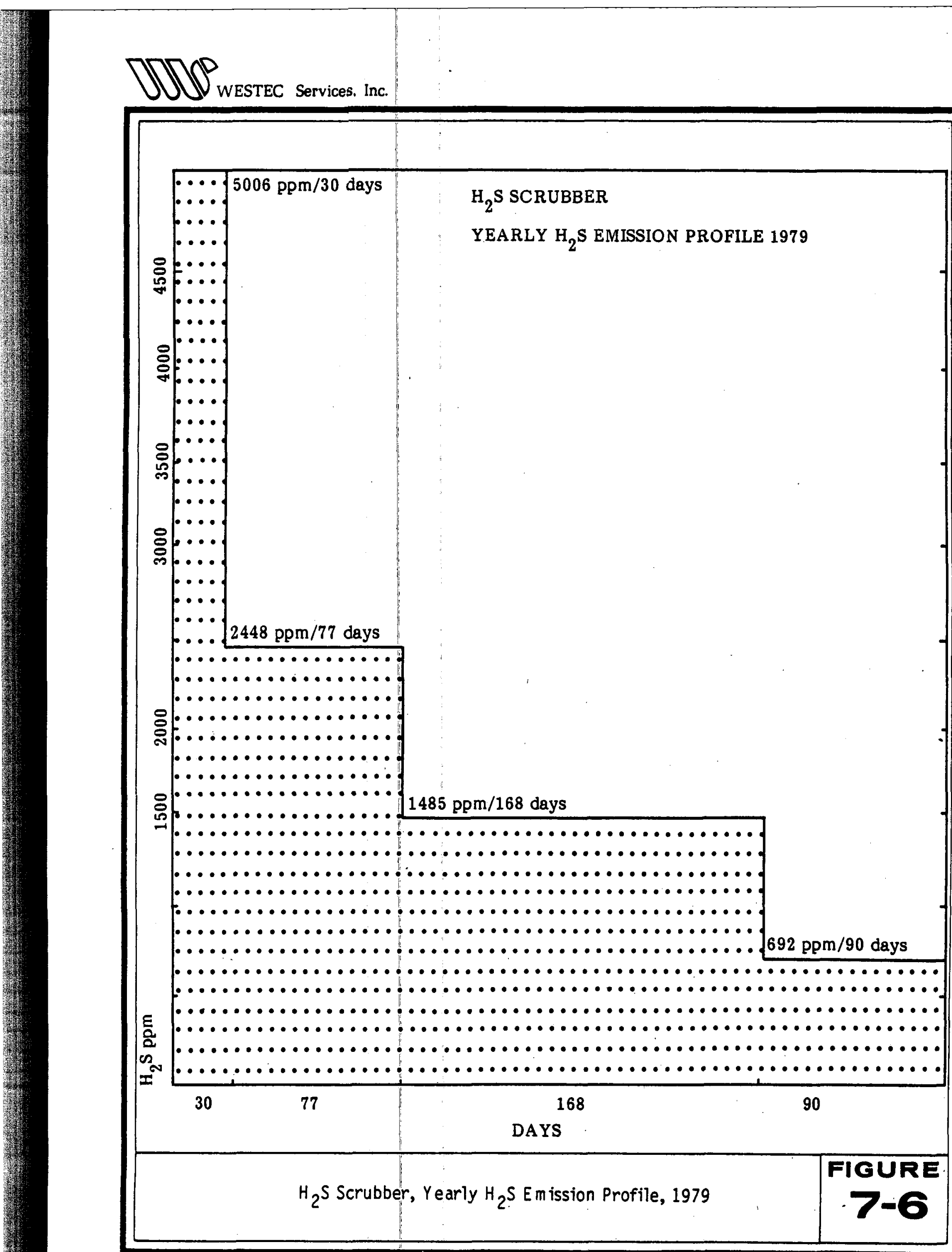




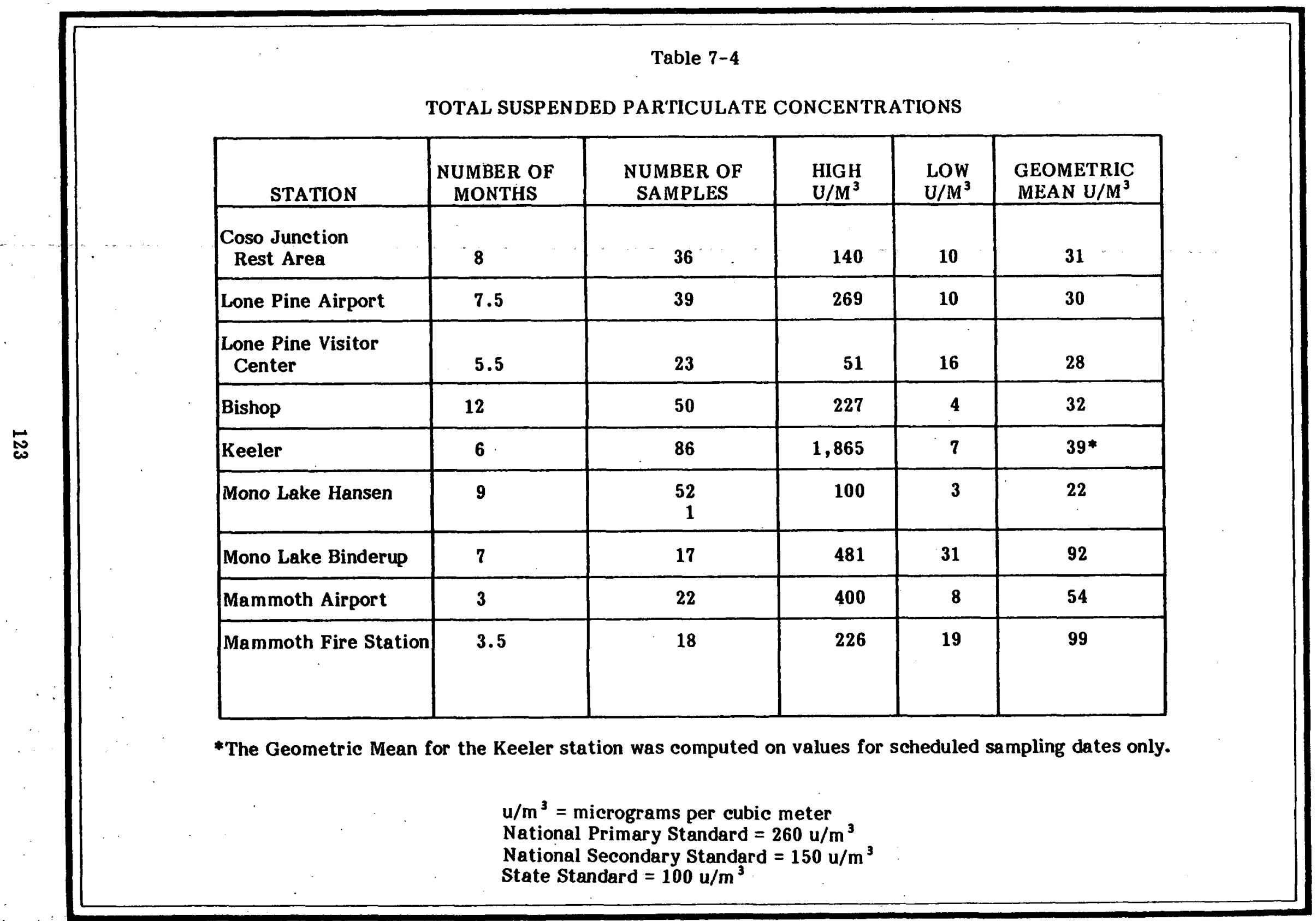


Table 7-5

TOTAL SUSPENDED PARTICULATES

STATE AND FEDERAL AMBIENT AIR QUALITY

STANDARD VIOLATION ANALYSIS

\begin{tabular}{|c|c|c|c|c|c|c|}
\hline & \multirow{2}{*}{$\begin{array}{c}260 \\
U / M^{3} \\
\text { EXCEEDED }\end{array}$} & \multirow{2}{*}{$\begin{array}{c}150 \\
\mathrm{U} / \mathrm{M}^{3} \\
\mathrm{EXCEEDED}\end{array}$} & \multirow{2}{*}{$\begin{array}{c}100 \\
\mathrm{U} / \mathrm{M}^{3} \\
\text { EXCEEDED }\end{array}$} & \multicolumn{3}{|c|}{ ANNUAL GEOMETRIC MEAN } \\
\hline & & & & NPS & NSS & SS \\
\hline $\begin{array}{l}\text { Coso Junction } \\
\text { Rest Area }\end{array}$ & - & - & 2 & - & - & - \\
\hline $\begin{array}{l}\text { Lone Pine } \\
\text { Airport }\end{array}$ & 1 & 1 & 2 & - & - & - \\
\hline $\begin{array}{l}\text { Lone Pine } \\
\text { Visitor } \\
\text { Center }\end{array}$ & - & - & - & - & - & - \\
\hline Bishop & - & 4 & 6 & - & - & - \\
\hline Keeler & 6 & 8 & 9 & - & - & - \\
\hline $\begin{array}{l}\text { Mono Lake } \\
\text { Hansen }\end{array}$ & - & - & 1 & - & - & - \\
\hline $\begin{array}{c}\text { Mono Lake } \\
\text { Binderup }\end{array}$ & 2 & 4 & 7 & $\mathrm{X}$ & $\mathrm{x}$ & $\mathrm{X}$ \\
\hline $\begin{array}{l}\text { Mammoth } \\
\text { Airport }\end{array}$ & 3 & 4 & 8 & & $\mathrm{X}$ & $\mathrm{X}$ \\
\hline $\begin{array}{l}\text { Mammoth Fire } \\
\text { Station }\end{array}$ & - & $\mathbf{5}$ & 8 & $\mathrm{x}$ & $\mathrm{x}$ & $\mathrm{X}$ \\
\hline
\end{tabular}

National Primary Standard

National Secondary Standard

State Standard

Annual Geometric Mean Standards

National Primary Standard

National Secondary Standard

State Standard

(NPS)

(NSS)

(SS)

(NPS)

(NSS)

(SS)

$$
\begin{array}{ll}
260 & \mathrm{U} / \mathrm{M}_{3}^{3} \\
150 \mathrm{U} / \mathrm{M}_{3}^{3} \\
100 \mathrm{U} / \mathrm{M}^{3}
\end{array}
$$

$$
\begin{aligned}
& 60 \\
& 50 \\
& 50
\end{aligned}
$$

Did not exceed

${\mathrm{u} / \mathrm{m}^{3}}^{3}$ micrograms per cubic meter

$\mathrm{X}$ Did exceed 
According to an environmental survey report submitted by the U.S. Forest Service in 1971 relating to the Pine Creek Tungsten Mine operation, the "discharge into the atmosphere (of pollutants) is relatively light from the mill and does not impart visually objectionable impurities. There is a definite sulfide odor which can be noted for miles both up and down the canyon. During windy periods, fine sediments are lifted from the tailings dump and pollute the air on a local basis before settling" (USDA, 1971).

Few fishermen use Pine Creek due to the lack of camping, picnicking and resort facilities. It is estimated that the area usage is generally 100 to 300 visitor days per year. Recreation opportunities in the canyon center around travel into the John Muir Wilderness Area just west of the mine and mill operations. The Pine Creek Pack Station, just south of the mill operations, provides pack service for about 250 wilderness travelers each season. Approximately 2250 backpackers leave yearly from the trailhead near the confluence of Gable Creek and Pine Creek (USDA, 1971). These people are currently impacted by the smell of hydrogen sulfide under certain weather conditions, however, Great Basin Air Pollution Control District has received no complaints and has not felt it necessary to monitor Pine Creek Canyon (Fryxell, 1980).

\subsubsection{Impacts/Constraints}

\subsection{Emission Sources}

Air pollutant emissions generally are greatest during the preoperational phase of geothermal resource development, rather than during continued operations. The sources of pollutant emissions from each phase of the project development and operations are discussed individually below.

\subsection{Drill Site Preparation}

Production and injection wells and related structures at the Pine Creek site will be located on previously graded surfaces, eliminating the major grading usually necessary for drill site preparation. Therefore, adverse effects created by this process, such as accumulation of fugitive dust and susceptibility of the earth to erosion, are not anticipated.

\section{2}

During drilling, emissions from diesel drives on the drilling equipment will release combustion emissions (principally oxides of nitrogen and carbon monoxide) that may create local pollutant concentrations. Additional minor vehicular emissions from drilling crew traffic could also be added to the local airstream if new workers do not use the bus. To quantify the amounts generated from these sources, additional information would be necessary regarding drilling equipment utilized, the number of persons included in the drilling crew, and their method of transportation to and from the site (bus or individual vehicles). If a high level of $\mathrm{H}_{2} \mathrm{~S}$ is encountered during drilling, small amounts may occasionally escape. However, normal drilling procedures generally do not create problems related to this emission. 
The most probable adverse effect of the Pine Creek project on air quality will occur during well cleanout; any noncondensable gases such as $\mathrm{H}_{2} \mathrm{~S}$ may be noted at nearby locations. Considering that only one injection well and one production well are anticipated at the site, the magnitude of this impact is expected to be low.

7.2.5.2.1.4

Operational Emissions

During operation of the geothermal system, $\mathrm{H}_{2} \mathrm{~S}$ could be emitted to the atmosphere. These amounts should be fairly low, due to the size of the project. As previously mentioned, this emission is currently released at the site because of the mine operation. Therefore, any addition would incrementally increase the present levels.

A definitive source receptor analysis of hydrogen sulfide emissions is possible because of the definite source and low threshold of odor nuisance. By applying a Gaussian diffusion equation to a wide scenario of meteorological conditions and input characteristics, the probable "envelope" of potential $\mathrm{H}_{2} \mathrm{~S}$ impact during well flow testing could be defined. This would probably be necessary since Union Carbide's current monitoring is generally done manually.

Any other increases anticipated to occur because of electrical generation or combustion of fuels would need to be identified and quantified. Based on the air pollution control district's air monitoring measurements of pollutants in the Bishop region, and on air monitoring occurring at the site, a standard emission analysis should follow. This analysis should include: (1) total suspended particulates, (2) sulfur dioxide, (3) carbon monoxide, (4) oxides of nitrogen, and (5) total hydrocarbons. Any sitespecific pollutants, such as hydrogen sulfide, sulfur dioxide, or ammonia, should also be quantified, and compared/with any state or federal standards.

\subsubsection{2}

Local Impacts

Visitors to the surrounding wilderness area would be affected by any increased air pollution emissions. Hydrogen sulfide would be the obvious of fender, and could degrade the quality of a wilderness experience. However, it should be noted that some natural wilderness areas which exhibit or are near thermal features also have this odor. As stated earlier, present discharge into the atmosphere is relatively light and does not impart visually objectionable impurities. The sulfide odor is already present and can be detected for miles up and down the canyon. The nearest urban center, Bishop, is located approximately 16 miles due east of the mine site; sulfide emissions are generally dispersed by this point.

The cumulative impacts of all emission sources is anticipated to be small, with the most serious impacts to aesthetics in the surrounding wilderness areas. The impacts to air quality are neither unique nor excessive and would not act as a constraint to the proposed geothermal project. 


\subsubsection{Mitigation/Alternatives}

Although the project impact is small, especially during the operational phase of the program when emissions are essentially negligible, certain specific actions will help minimize the air quality impact. Regular watering during any dust raising construction, drilling and testing activities could reduce local dust levels. If the number of vehicles traveling to and from the site during the site preparation phase is anticipated to increase, then restricting direct access to the site, or preparing an oiled access and parking area could reduce air quality impacts from vehicles. New employees should be strongly encouraged to use the bus provided by Union Carbide Corporation.

The fact that geothermal energy will replace energy generated by the combustion of fossil fuels will result in a net air quality improvement. Average system energy savings can be computed when more information is available regarding the resource. In addition, the total resulting emissions can be computed and compared with current emissions if the project proceeds. Future mitigation measures may be necessary and can be presented when the project is more fully defined.

\subsubsection{Visual Quality/Aesthetics}

\subsubsection{Environmental Setting}

The project site is located at the western end of Pine Creek Canyon on the eastern side of the Wheeler Crest, a north/south trending ridge between the main Sierra crest to the west and Round Valley (the northern extension of Owens Valley) to the east. The existing tungsten mine is tunneled beneath the lower slopes of Mount Morgan but is not visible on the surface except for the portals (mine entrances). The tungsten mill and related facilities are situated near the confluence of Pine, Morgan, and Gable Creeks. The Pine Creek Pack Station is just south of the Union Carbide facilities and trails into the John Muir Wilderness Area leave from three locations in the vicinity of the Union Carbide operations. The trailhead near the pack station is the most frequently used trail (Leys, 1980).

The Union Carbide Tungsten Mine, mill, and related facilities are located at the end of a road traversing the length of Pine Creek Canyon. This road begins at U.S. Highway 395 approximately 9.3 miles $(14.9 \mathrm{~km})$ north of Bishop. The portions of Highway 395 both north and south of the road to Pine Creek Canyon have been nominated as part of a scenic highway system for Inyo County. However, Pine Creek Canyon is not visible from Highway 395 because of its distance (approximately 6 miles from the highway to the easternmost portion of the canyon) and the intervening topography.

The road to Pine Creek Canyon passes through Rovana, a very small residential area where Union Carbide employees live. The tungsten mine and mill facilities are located at the western terminus of the road and are not visible from the residential area or from any populated area or major road. The Union Carbide mine and mill facilities are not generally visible from the road to the east until the last tailings pond is passed or from the pack station to the south due to the nature of the topography, forest vegetation, and the location of the road. The tailings ponds which settle out the mine and mill waste products and the pipelines which carry the wastes from the mill 
and mine to the tailings ponds are highly visible from the road. The silver tunnels used to encase the pipelines in some areas to prevent breakage from collapsing snow drifts are highly visible in the eastern end of the canyon, as are the steep slopes cut out of the nor thern hillsides for the road and tailings ponds. These features are visible from the surrounding wilderness forested areas as well as from the road.

The Union Carbide Tungsten Mine, mill, and related facilities are located just north of Pine Creek and immediately west of Morgan Creek. A narrow dirt road switchbacks up a steep slope just east of Morgan Creek to another mine portal. The appearance of the mill and office building area on the lower level is a startling contrast to the natural scenery but is dominated and dwarfed by the surrounding mountain scenery. The rock crusher building and conveyor tunnel located on the upper pad at a higher elevation are far more dominant than the buildings at the lower elevation. Numerous locations around the buildings are used for storage of parts and equipment which are not aesthetically pleasing.

The mine, mill and related facilities are expected to be visible from the old mining road which is now a hiking and riding trail leading from the Pine Creek Pack Station into the John Muir Wilderness Area. Another narrow dirt road leading to the previously used mine portals at higher elevations on the east side of Morgan Creek and any mining machinery left in that vicinity are probably visible to hikers and packers visiting Lower Morgan Lake and Mount Morgan.

A brief visual survey of Pine Creek Canyon during the winter season, when snow covered many areas, prevented an in-depth reconnaissance to determine if equipment stockpiles and mining debris are visible. If the proposed geothermal project proceeds, the environmental document should include field surveys of Pine and Morgan Creek Canyons and the lowest portion of the Gable Creek drainage, as well as the area surrounding the mill. This would serve to update the environmental data base for the area and would facilitate future monitoring of rehabitation.

\subsubsection{2}

\section{Potential Impacts/Constraints}

The introduction of geothermal testing and production equipment into the immediate area of the existing Pine Creek Tungsten Mine and mill would have an almost unnoticeable visual impact which would be largely temporary. The geothermal well would necessarily be placed somewhere on the existing pads of either the mill area or the upper area pad around the mine portal and electric substation, where much machinery already exists. Thus, the aesthetic impact would be insignificant. In addition, the drilling rigs would be temporary. From a close-up view, the transformation could even be a positive effect if the wells were placed in areas now used for parts storage or unpaved parking areas. There are no visual/aesthetic considerations whic:: would act as a constraint on the proposed project unless the wells were to be located away from the existing facilities.

\section{Mitigation/Alternatives}

The presence of a drilling rig would probably be less obtrusive if located on the lower pad area rather than on the upper area near the mine portal. No other mitigation is considered necessary. 


\subsubsection{Environmental Setting}

7.2.7.1.1 Land Ownership

The vast majority of land within a $14-$ mile $(22.5 \mathrm{~km})$ radius of the Pine Creek tungsten mine and facilities is publicly owned (Figure 7-7). Most of Round Valley, the Tungsten Hills, and the volcanic tableland to the east are within the Owens Valley Planning Unit of the Bureau of Land Management's Bishop Resource Area (Figure 7-8). At least 82 percent of the public lands in this planning unit have been withdrawn for special purposes, primarily the protection of the watershed for the benefit of the City of Los Angeles.

The vast majority of land in Pine Creek Canyon and in the nearby vicinity is under the jurisdiction of the U.S. Forest Service as part of Inyo National Forest, though there are a few isolated portions of land under private ownership. Approximately 20.7 acres $(8.4 \mathrm{ha}$ ) just below the former location of Scheelite are owned by Inyo County.

The Forest Service's Mammoth-Mono Planning Unit (MMPU) encompasses 695 square miles $(444,744$ acres or 180,121 hectares) of land and water north of Pine Creek. The MMPU includes the John Muir Wilderness Area, which surrounds Pine Creek and Morgan Creek Canyons on three sides at higher elevations and includes Gable Creek Canyon (Figure 7-7). This wilderness area is administered by the Inyo National Forest of fice and requires a permit for entry.

The Pine Creek Tungsten Mill and related facilities are on privatelyowned land within the publicly-owned Inyo National Forest. Much of the associate surface activities involve National Forest land under special use permits, mining, and millsite claims (Figure 7-9).

\subsection{Existing Land Uses}

Mining operations have dominated land use in Pine Creek Canyon since 1918. Early operations were situated in the hanging valley of Morgan Creek between 11,000 and 12,000 feet $(3353 \mathrm{~m}$ and $3658 \mathrm{~m})$, with access via the Rock Creek drainage and Morgan Pass. Union Carbide Corporation acquired an interest in the property in 1936 and has since enlarged and improved the mining and milling capacity. There may be previous mining and processing remnants at the 11,000 foot $(3353 \mathrm{~m})$ level above Morgan Creek Canyon. The steep narrow road leading to the former mine portal is still evident.

A small area known as Scheelite, located almost midway in Pine Creek Canyon, previously contained a tungsten processing plant and housing for Union Carbide employees. Although these have been removed, it is expected that this area probably is still used for storage. Approximately 20.7 acres (8.4 ha) just below Scheelite were previously used for a federal housing project constructed during World War II; the land is now owned by Inyo County. Although the buildings were removed, it is probable that some foundations still remain. 


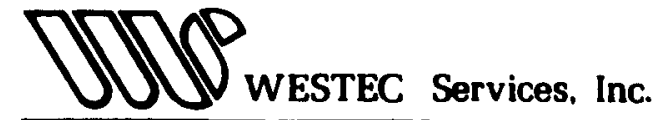

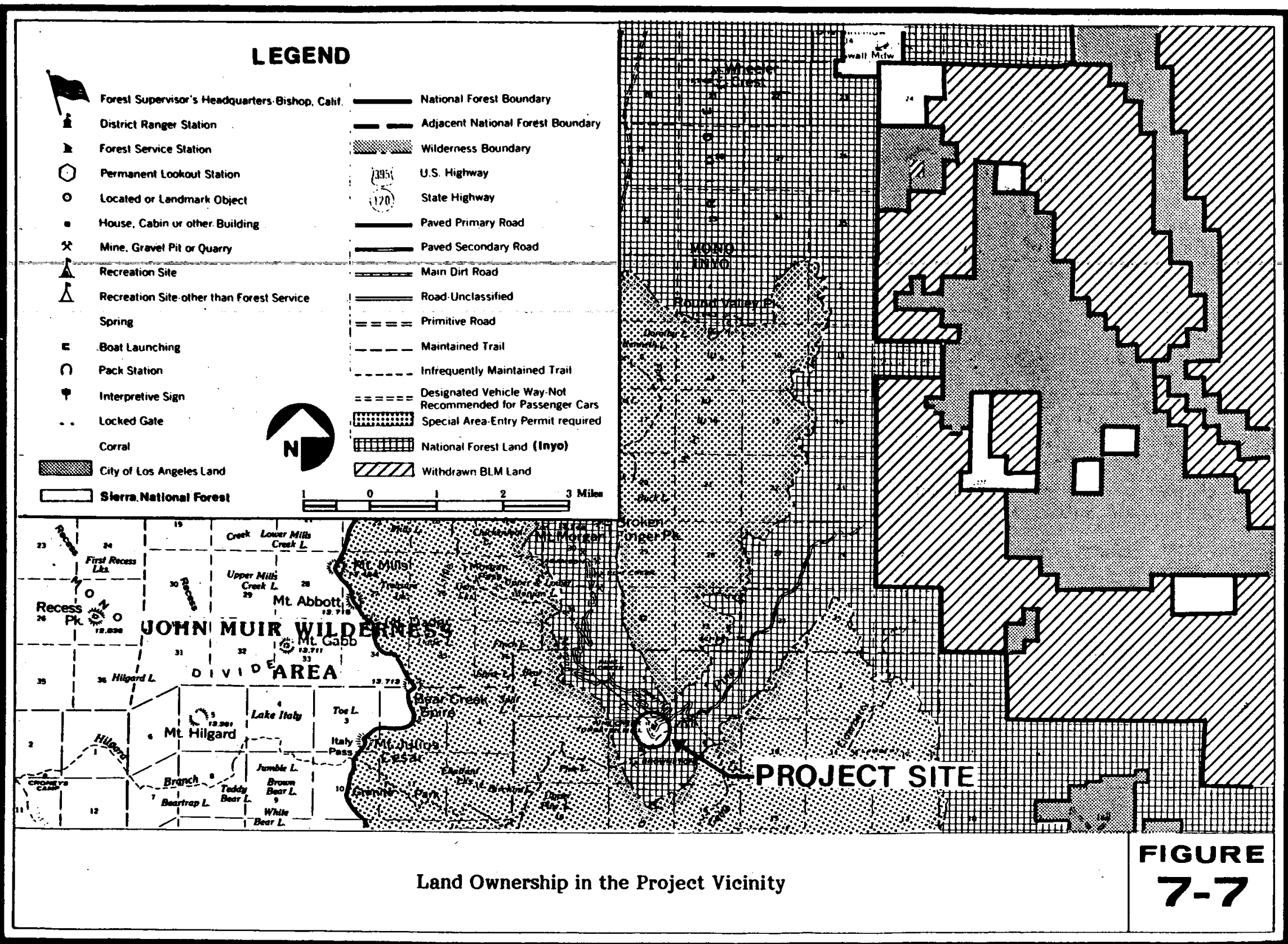




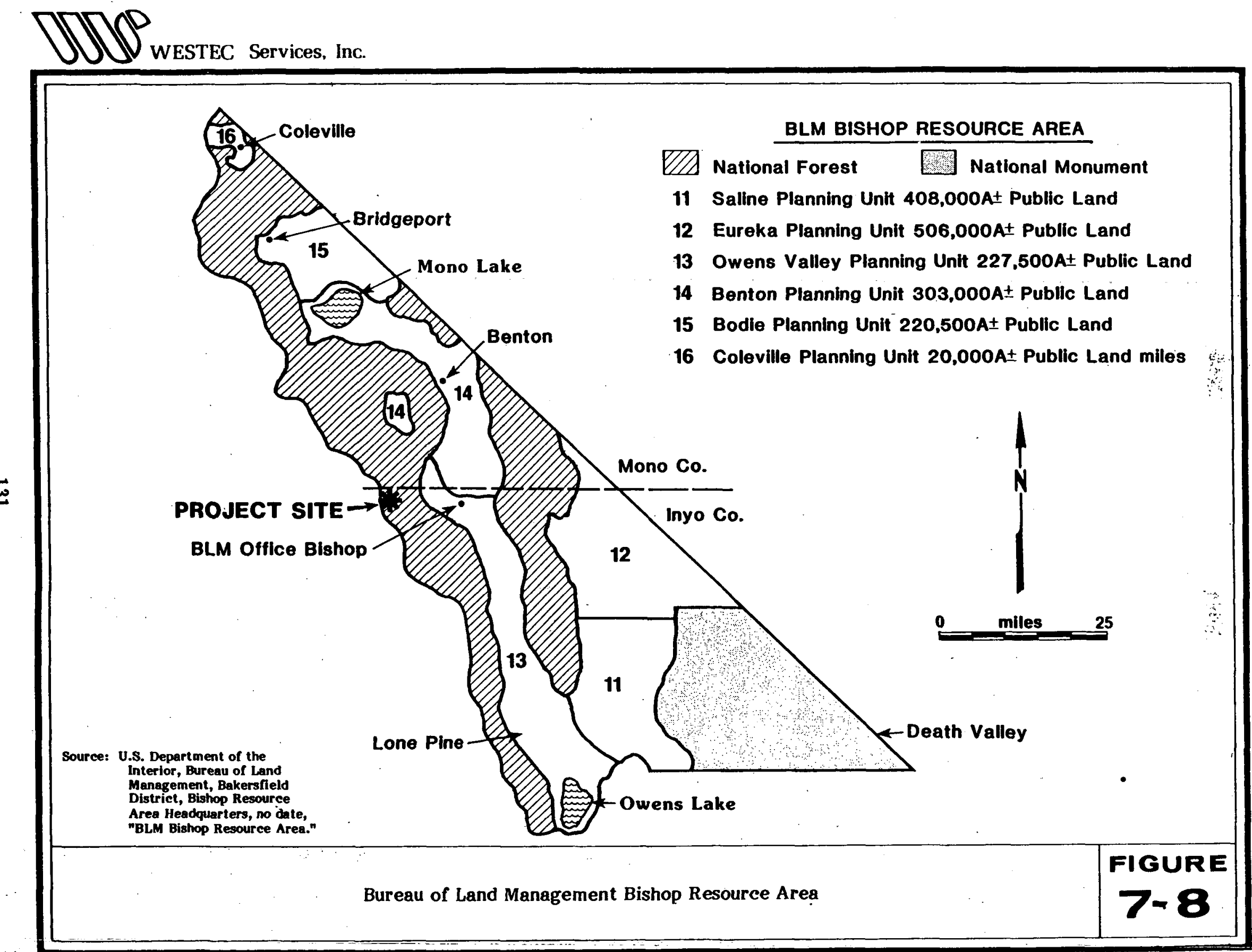


Dopep

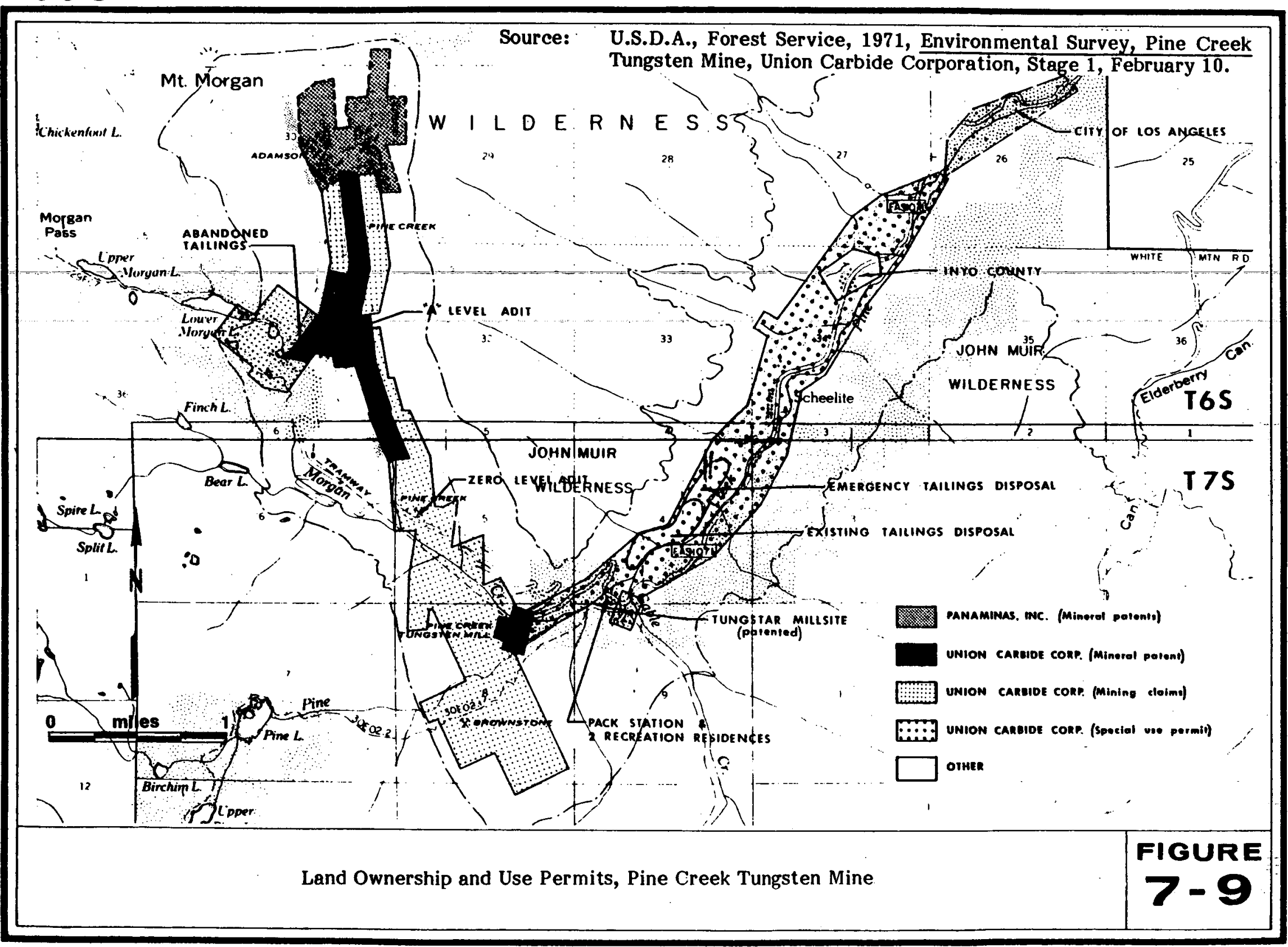


Several tailings ponds are located adjacent to the road south of the mill site. Other remnants of past mining activity exist in the area near the confluence of Gable Creek and Pine Creek Canyons.

The Union Carbide Tungsten Mine, mill and related facilities are located at the westernmost (upper) end of Pine Creek Canyon and dominate the land use in that area. The tailings ponds and pipelines adjacent to the road are the first evidence of mine activities as one approaches from the east. The Union Carbide offices, the tungsten mill and its related facilities, and the parking areas are located just north of Pine Creek and immediately west of Morgan Creek at approximately 8000 feet. An unpaved road leads up to the mine portals, the "easy go tunnel," and the electrical substation at about 9500 feet $(2896 \mathrm{~m})$ on the west side of Morgan Creek. In addition, an unpaved road switchbacks up the hillside east of Morgan Creek to previously used mine portals and facilities at 11,000 feet $(3353 \mathrm{~m})$.

Pine Creek flows nearly year-round, however, few fishermen use the creek because of the lack of camping, picnicking, and resort facilities. Camping has been restricted in the canyon since about 1948 because Pine Creek was then the domestic water supply for the residents in Rovana, just east of the canyon. Rovana no longer relies on Pine Creek, however, the restrictions have never been lifted. It is estimated that the area usage is generally 100 to 300 visitor days per year. Recreational opportunities in the canyon center around travel into the surrounding John Muir Wilderness Area. The wilderness area is a popular one for hiking and back country activities. The Pine Creek Pack Station just south of the tungsten mill and related facilities generally provide pack service for about 250 wilderness travelers each year (USDA, 1971).

The John Muir Wilderness Area nearly surrounds the Pine Creek Tungsten Mine and mill on three sides. It includes all of the land at higher elevations above the rims of Pine Creek and Morgan Creek Canyons and most of Gable Creek Canyon. Heavily used by backpackers, it is a popular back country area. The Forest Service has recently had to limit the number of permits for this wilderness area to 50 people per day (Leys, 1980). At least 2250 of these annually leave from one of the trailheads in Pine Creek Canyon (USDA, 1971), primarily from the trailhead that follows Pine Creek up to Pine Lake (Leys, 1980).

\subsection{Land Use Management}

The U.S. Forest Service defines the land use management goals and policies for the project site and all of the land immediately surrounding the site. The Mammoth-Mono Planning Unit's Land Management Plan includes a portion of the John Muir Wilderness Area to the northwest of Pine Creek Canyon (USDA, 1979). The entire Pine Creek Canyon area is within the Forest Service's White Mountain Ranger District within Inyo National Forest. The Pine Creek area, as well as the surrounding wilderness land within Inyo National Forest, is currently covered by the Forest Service's 1972 Multiple Use Plan for Inyo National Forest. Although this plan is still in effect, it is currently being updated. The revised plan is expected to be completed by 1983 and will replace the Mono-Mammoth Planning Unit Land Management Plan. (Suter, 1980).

The 1972 Multiple Use Plan for Inyo National Forest noted that mining was the dominant land use in Pine Creek Canyon at that time. It also noted that mining 
has effects on other resources and recommended restoration measures for mined areas. The plan made a number of recommendations relating to land use management in Inyo National Forest. It was recommended that the Forest Service should: (1) acquire as much private land as possible; (2) construct and develop trails and trail facilities; (3) construct day-use facilities at trailheads, such as the trailhead for the Gable Lakes trail; (4) prepare a recreational composite management plan for the Pine Creek water influence and crest zone; (5) eliminate unnecessary storage areas around the mines inside the national forest; and (6) develop new tailings ponds which will be more easily restored to natural conditions upon closing of the mine (Leys, 1980).

\subsubsection{Potential Impacts/Constraints}

The addition of a geothermal resource program to the immediate vicinity of the Pine Creek Tungsten Mine and mill would probably have no significant land use impacts since this would merely be an extension of the existing industrial uses onsite. The existing land use plan for Inyo National Forest recognizes the presence of the mine and has sought only to improve rehabilitation of the area; it has not proposed the elimination of the current uses.

If the proposed geothermal well drilling and testing period generates a substantially larger number of people in the area than there are at present, the use of the canyon for quiet activities such as fishing, hiking and birdwatching could be further impacted. However, this would be a temporary effect and would diminish after the testing period. It is likely that the geothermal operations onsite will hardly be noticeable and will be far less significant then the existing mining operations.

The other potential secondary land use effects of geothermal production relate to the presence of sulfurous odors during certain weather conditions and noise intrusions into a wilderness area, and thus, the reduction of the quality of the wilderness experience. However, it should be noted that many natural geologic features emit sulfurous odors and it is possible that this odor might be present in the area even without any man-made intrusions.

In summary, there are no potential land use impacts which would act as a constraint on the proposed geothermal program as long as the wells are on the existing pads.

7.2.7.3

Mitigation/Alternatives

The proposed geothermal program would have the least land use impacts if the wells were located in the immediate vicinity of the existing mill and related facilities on the lower level (8000 feet).

7.2.8

Archaeological Resources

7.2.8.1

Environmental Setting

The Pine Creek Tungsten Mine is situated at an elevation of approximately 8000 feet above mean sea level along the eastern slope of the Wheeler Crest. Located near the juncture of Pine and Morgan Creeks, the project site is within the 
upper montane-subalpine forest formation. Dominant species include Jeffrey pine (Pinus jeffrey) and fir (Abies sp.).

The mill itself is situated on a man-made flat created by filling a portion of the canyon floor with mine tailings. An adjacent hillside has been terraced to accommodate mine facilities. Natural slopes surrounding the project are steep bedrock and talus slopes, frequently exceeding 50 percent.

The presence of a steady water flow, timber for shelter and construction material, and readily available food sources would have made the Pine Creek area a suitable place for human habitation and exploitation. The availability of large bedrock outcrops in the vicinity of the tungsten mill that could have been used for milling or processing food stuffs further increases the potential for aboriginal use.

A survey of available literature and record searches at the University of California at Riverside and the U.S. Forest Service White Mountain Ranger District indicates that no known archaeological or historical sites are situated on or within 3 miles at the project area. However, it should be stressed that no field survey has been conducted within the project vicinity or on the Union Carbide property. It is possible that although badly impaired by landform alteration, unexamined and thus undiscovered sites may exist. It is also possible that the Pine Creek area possesses historical significance as a technological-historical feature of the land.

The lack of research and field surveys in the area makes it difficult to estimate the potential for archaeological resources. However, it can be generally stated that the Native Americans who occupied the general project area in prehistoric times were probably Northern Paiutes, a Shoshone-speaking tribe. Their two tribal groups, the Mono Lake Paiute and Owens Valley Paiute, were nomadic and somewhat dependent on seasonal food supplies. These two tribes have left tools and structures in areas slightly to the north indicating at least 6000 years of occupation. In some of those areas, the predicted archaeological site densities ranged as high as 51 sites per square mile (U.S. Forest Service, 1979b; Heizer and Whipple, 1973; Powers, 1976).

\subsubsection{Potential Impacts/Constraints}

Until a field survey is conducted in and around the project site, potential impacts to, or adverse effects upon, cultural resources cannot be determined. Past impacts to the landform may have already destroyed or badly impaired cultural resources if they existed on the project site. Although it is possible that such resources still exist, the probability is relatively low given the degree of landform alteration. Nevertheless, further destruction or impairment of cultural resources would constitute adverse impacts. Evidence dating from early historic mining and ranching activities are probably the most likely materials to be encountered, although prehistoric material could also be present (Goggin, 1980; McCarthy, 1980).

\subsubsection{Mitigation/Alternatives}

To ensure that potential adverse impacts will not occur to cultural resources that may exist on the project site, a series of data recovery programs are recommended. Phase I should consist of a 100 percent in-field systematic survey of the 
entire project area and adjacent areas that may be indirectly affected. If the survey is negative and no cultural resources are encountered, mitigation will be achieved through report preparation and official review. This should include an analysis of the historical significance of the area. The absence of resources will preclude the necessity for further analysis or research.

Should cultural resources be discovered on or near the project area, mitigation can be achieved through: (1) full preservation of significant resources, (2) partial preservation in combination with a data recovery excavation program or (3) full site salvage and data recovery through an extensive data recovery excavation program. Regardless of which Phase I mitigation program is pursued, the historical significance of the area should be fully discussed. Any proposed mitigation program beyond the Phase I field survey should be carefully coordinated with the State Office of Historic Preservation, the Native American Heritage Commission, and other involved agencies.

The Natelson Company, a private consulting firm in Los Angeles, is preparing a joint Geothermal Element of the General Plan for Mono and Inyo Counties with a specific element for each County which should be available by fall 1980. Environmental statements which support the geothermal leasing program have been prepared by the Department of the Interior beginning in 1973. The Bureau of Land Management State office in Sacramento is presently reviewing those statements that pertain to Inyo County, and will forward them to WESTEC. Additional data for the region as a whole may be available from private companies in the area, such as Southern California Edison. A complete data search for the region would require much additional research in the Bishop, Independence and Sacramento areas.

\section{4}

\section{CONCLUSION}

The environmental assessment failed to turn up any potentially significant environmental effects which might result from geothermal development at the Pine Creek Tungsten Mine and mill sites. As long as the geothermal facilities are located on the existing pads, no significant adverse environmental effects are anticipated. If the facilities were to be located anywhere else, additional environmental research would be necessary.

In order to meet the requirements of the National Environmental Policy Act (NEPA) and of the California Environmental Quality Act (CEQA), certain additional environmental research would be required before any geothermal program could be initiated. A biological field survey would have to be conducted during a snow-free period, followed by a written report. The report would have to include an inventory of vegetative types, a discussion of high interest plant and animal species known or thought to be in the immediate vicinity of the mine and mill facilities, and a notation of areas with potential problems. The biological report could be tied in with a visual survey of Pine Creek, Morgan Creek, and Gable Creek Canyons and the portion of the John Muir Wilderness Area directly above and adjacent to these canyons. The visual survey should note existing disturbed areas and the general health of the forest. Color photographs should be taken of areas where numerous plants or trees appear to be unhealthy or where there is a noticeable absence of wildlife. Yearly visual surveys, and 
possibly some biological reconnaissance, should be used to monitor any changes in the health of the forest for the duration of the geothermal program. There is already a good deal of water quality monitoring in Pine Creek Canyon. This should be continued and tied in with the biological and visual surveys to document possible impact areas.

A full archaeological survey of all open areas around the mine and mill facilities should be conducted. If no cultural resources are encountered, the written report will end the research. If cultural resources are discovered on or near the project area, there are generally a number of possible data recovery programs available. These alternatives can almost always be used to mitigate potential environmental effects to a level of insignificance.

Air quality monitoring in Pine Creek Canyon and in the John Muir Wilderness Area directly above the canyon should be conducted prior to and during the life of the geothermal operations. At the minimum, this monitoring should measure the amounts of hydrogen sulfide and particulates. A quantitative analysis should then be made of the increased amount of various emissions as compared with the decreased emissions resulting from the elimination of a portion of the fuel oil currently burned to produce power. 


\section{REFERENCES}

Brewer, George, 1980, Union Carbide, personal communication, January.

California Department of Fish and Game, 1965, California Fish and Wildlife Plan, The Resources Agency, Volume 3(c):908.

California Department of Fish and Game, 1978, At the Crossroads: A Report on California's Endangered and Rare Fish and Wildlife, The Resources Agency.

California Department of Fish and Game, 1979a, "Endangered and Rare Plants of California," The Resources Agency, October 5.

California Department of Fish and Game, 1979b, News Release Regarding Banning of Pet Trade in Reptiles and Amphibians, May 29.

California Native Plant Society, 1974, Inventory of Rare and Endangered Vascular Plants of California, edited by W. Robert Powell, Special Publication No. 1.

Fryxell, Charles L., 1980, Control Officer, Great Basin Unified Air Pollution Control District, Bishop, California, written communication, February 21.

Goggin, Michael P., 1980, District Ranger, White Mountain Ranger District, U.S. Forest Service, correspondence, March 6, 1980.

Greensfelder, R.W., 1974, Maximum Credible Rock Acceleration from Earthquakes in California, California Division of Mines and Geology, Map Sheet 23.

Heizer, R.F. and Whipple, M.A., 1973, The California Indians, second edition, University of California, Berkeley.

Inyo County, 1979, Scenic Highway Element of the Inyo County General Plan, February 13.

Jennings, C.W., 1975, Fault Map of California with Locations of Volcanoes, Thermal Springs and Thermal Wells, California Division of Mines and Geology, California Geologic Data Map Series, Map No. 1.

Kuchler, W., 1977, "The map of the Natural Vegetation of California," Terrestrial Vegetation of California, edited by Michael G. Barbour and Jack Major, John Wiley \& Sons, New York.

Leys, Art, 1980, U.S. Forest Service, Inyo National Forest Office, Bishop, California, telephone communication, April 1.

Powers, Stephen, 1976, Tribes of California, University of California, Berkeley. 
Rundel, Philip W., David J. Parsons and. Donald T. Gordon, 1977, "Montane and Subalpine Vegetation of the Sierra Nevada and Cascade ranges," Terrestrial Vegetation of California, edited by Michael G. Barbour and Jack Major, John Wiley \& Sons, New York.

Stefferude, Jerry, 1980, Biologist, U.S. Forest Service, Bishop, personal communication, March 4, 1980.

Suter, Bob, 1980, U.S. Forest Service, White' Mountain Ranger District, Bishop, California, telephone communication, April 1.

Union Carbide Corporation, 1979a, "Schematic of Waterflow, Pine Creek Operations, Bishop, Inyo Company, California," January 25.

Union Carbide Corporation, Metals Division, 1979b, "3rd Quarter Energy Report, Bishop Operations," November 1.

U.S. Bureau of Land Management (BLM), 1979, "Aquatic Habitat Inventories," Form $6671-5$, September.

U.S. Department of Agriculture (USDA), Forest Service, 1971, "Environmental Survey Report, Stage I, Pine Creek Tungsten Mine, Union Carbide Corporation," February 10.

U.S. Department of Agriculture (USDA), Forest Service, 1979, Final Environmental Statement, Land Management Plan for the Mammoth-Mono Planning Unit.

U.S. Department of Commerce, National Climatic Center, (no date (n.d.)), "Local Climatological Data, Annual Summary with Comparative Data, 1978, Bishop, California."

U.S. Fish and Wildlife Service, 1979, "List of Endangered and Threatened Wildlife and Plants" (Republication), Department of Interior, Federal Register 4(12):3636-3654, Wednesday, January 17. 


\section{SECTION 8}

\section{ALTERNATE GEOTHERMAL ENERGY SOURCE}

\subsection{INTRODUCTION}

Installation of a geothermal energy system described for use at the Pine Creek complex was designed for a resource that would deliver fluid with a temperature of $121 \mathrm{C}(250 \mathrm{~F})$ at the wellhead. Reaching geothermal fluid at this temperature may not be economically possible at Pine Creek because of the projected depth to which drilling would be required based on the initial geophysical interpretation of the surrounding area and geochemical analysis of local groundwater. An examination of other local resources was undertaken to determine possible options for replacing some portion of conventional energy requirements at the Pine Creek tungsten complex with geothermal energy.

A survey of alternative energy potential for use at the Pine Creek tungsten complex first evaluated the feasibility of transporting geothermal fluid from a known resource. An abbreviated map of Mono and Inyo Counties shows the proximity of the Mono-Long Valley Known Geothermal Resource Area (KGRA) to the Pine Creek tungsten complex in Figure 8-1. This possible location for drilling geothermal wells to supply energy to the Pine Creek tungsten complex is described in further detail below.

\subsection{TRANSPORTATION FROM MONO-LONG VALLEY}

The closest known geothermal resource area to the mining and processing complex is the Mono-Long Valley KGRA which is approximately 30 miles from the project site. Considering the high temperatures of brine in this KGRA at relatively shallow depths, the geothermal fluid has the potential of being delivered economically to the mill site. The surrounding topography of the eastern Sierras is the main complication in the discussion of fluid transportation. Heat losses over long distance transport are compounded by the expense of pumping fluid over the mountainous terrain to reach the mill site.

The major cost of this project will be the pipeline from the KGRA to the Pine Creek tungsten complex, a distance of 34 miles if the pipeline route parallels existing roads. If required, an injection pipeline will be laid concurrently with the production pipeline which will reduce pipeline installation costs per foot of pipe. If possible, reinjection will be conducted on the Pine Creek tungsten complex to reduce the large capital expense associated with the additional pipeline.

Various parameters influence the economic viability for geothermal fluid transport. Ideally, the point of end use should be located near the supply of geothermal fluid, high temperature fluid should be transported to a large concentrated market, and the load factor for the geothermal system should be high. The unit cost of delivering heat in large pipes to meet large demands is much lower than delivering heat in small pipes to a small market. Large pipes are also attractive because they have a low surface area-to-volume ratio which reduces the percentage of heat loss from each pound of fluid. 


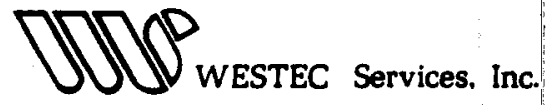

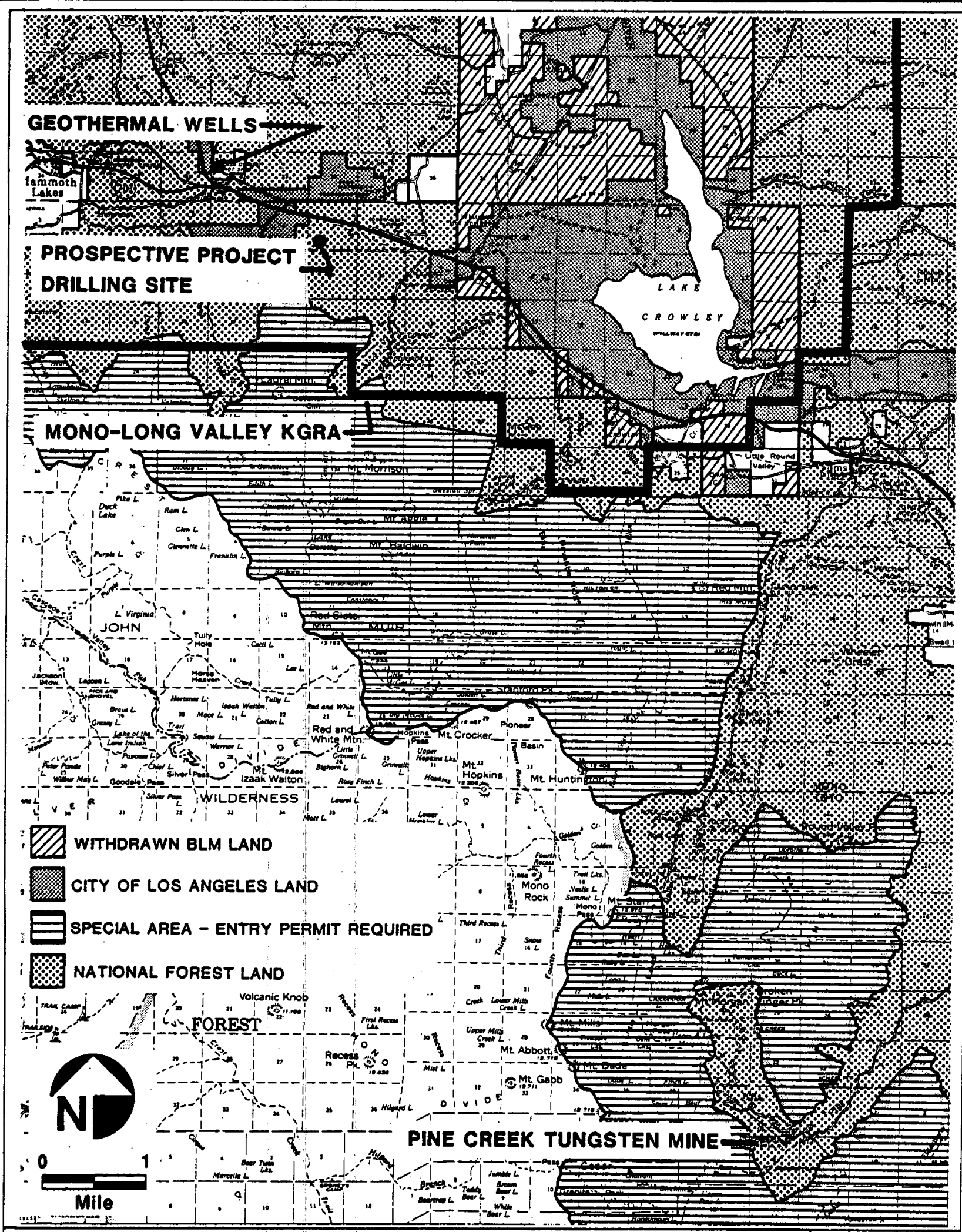

FIGURE

ALTERNATE STTE LOCATION MONO-LONG VALLEY KGRA

8-1 
It is anticipated that high year-round load factor can be achieved at the tungsten mining complex because of the industrial water requirements. The tungsten mill normally operates 24 hours a day, 365 days a year and the steam requirements are fairly constant for the tungsten processing. If the geothermal system is sized to handle the peak space heating load, the annual utilization factor should approach 40 percent. Fluid transport costs are primarily fixed costs with the exception of pumping expenses because the high initial capital expense of pumps and pipelines is independent of the utilization of pipeline capacity. Although variable costs increase slightly as the load factor increases, due mainly to additional pumping costs, the unit cost of delivered energy decreases as the load factor of system capacity increases (see Figure 8-2) because the large fixed costs are spread over more units of production.

\subsection{SITE SELECTION}

Three locations for a possible drilling site within the Mono-Long Valley KGRA were chosen for review of environmental, engineering and institutional constraints to project development. Casa Diablo in T3S, R28E, Sec. 32 of Mono County was chosen for further investigation because of the prior sucessful geothermal wells drilled at this location. Two other sites are discussed, T4S, R28E, Sections 2 and 3; chosen in part for the minimal environmental impact of geothermal development based on the Environmental Assessment published by the USDA Forest Service as shown in Figure 8-3 (Rice, 1980). These two sites specifically allow drilling of deep geothermal wells, plant siting and other activities related to geothermal development.

An additional criterion for drill site location is the need for transmission of the geothermal fluid to the Pine Creek mill site. The cost of the finished transmission system will be dependent on the ease of access to the pipeline corridor for construction crews and equipment. All of the drill sites under investigation were located adjacent to U.S. 395 to minimize construction costs and facilitate grants for right-of-way.

\subsection{LONG DISTANCE HOT WATER TRANSPORT}

A major consideration in using geothermal fluid from the Mono-Long Valley is the economics of heat transport over the 34 miles from the proposed drilling site to the Pine Creek tungsten mine. The cost of delivering energy as related to pipe diameter is a function of the maximum rate or capability at which the pipeline can deliver energy to the customer. This in turn is dependent on specific choices of a number of variables: flow rate, insulation properties, delivery temperature and temperature drop of the geothermal fluid. The delivered cost of a Btu decreases as the demand, within the pipelines capacity, increases. If the transport pipes are used for a small temperature difference between delivery and return the required pipe dimensions are larger for delivering the same amount of heat (See Table 8-1). 


\section{DNO}

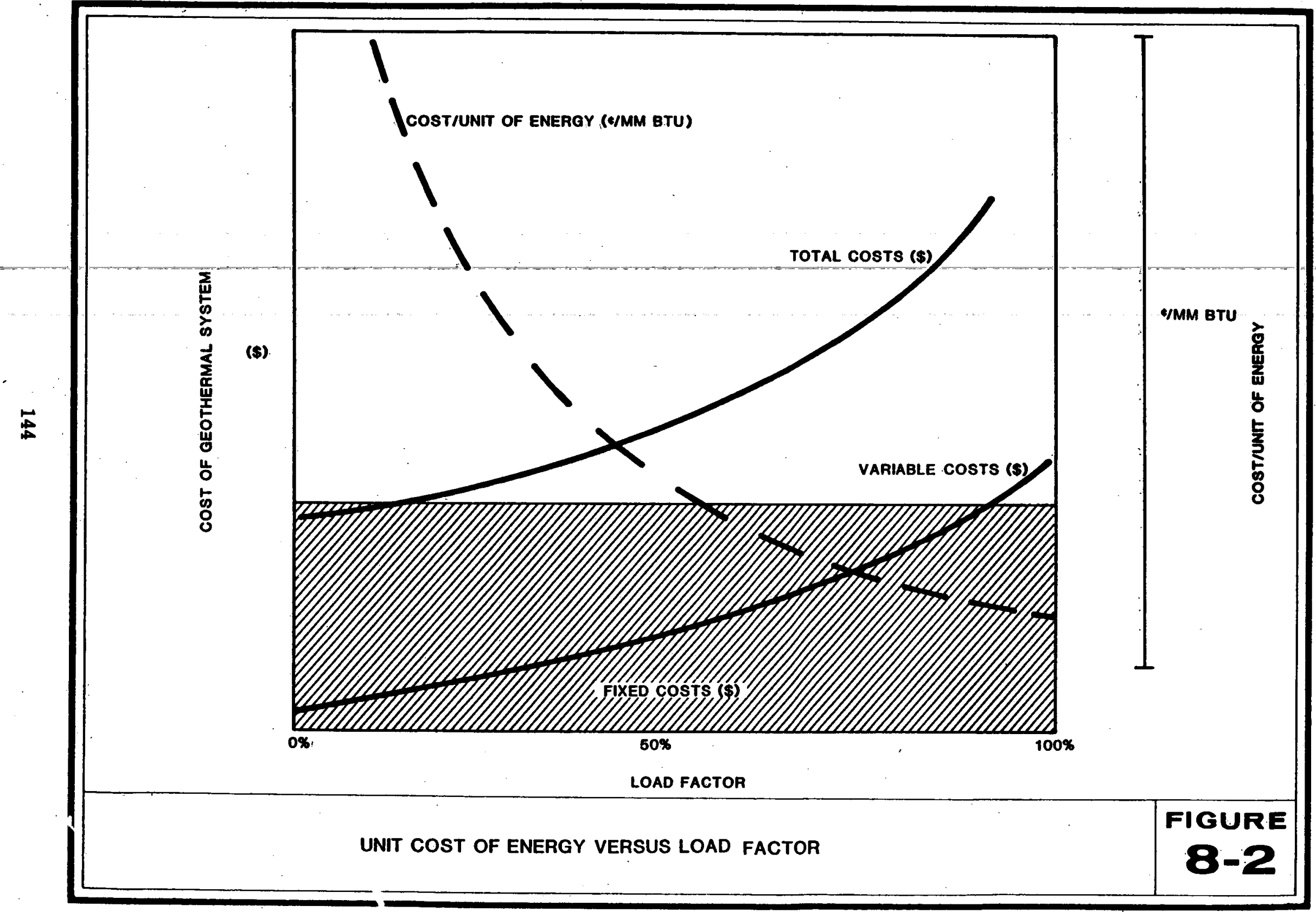




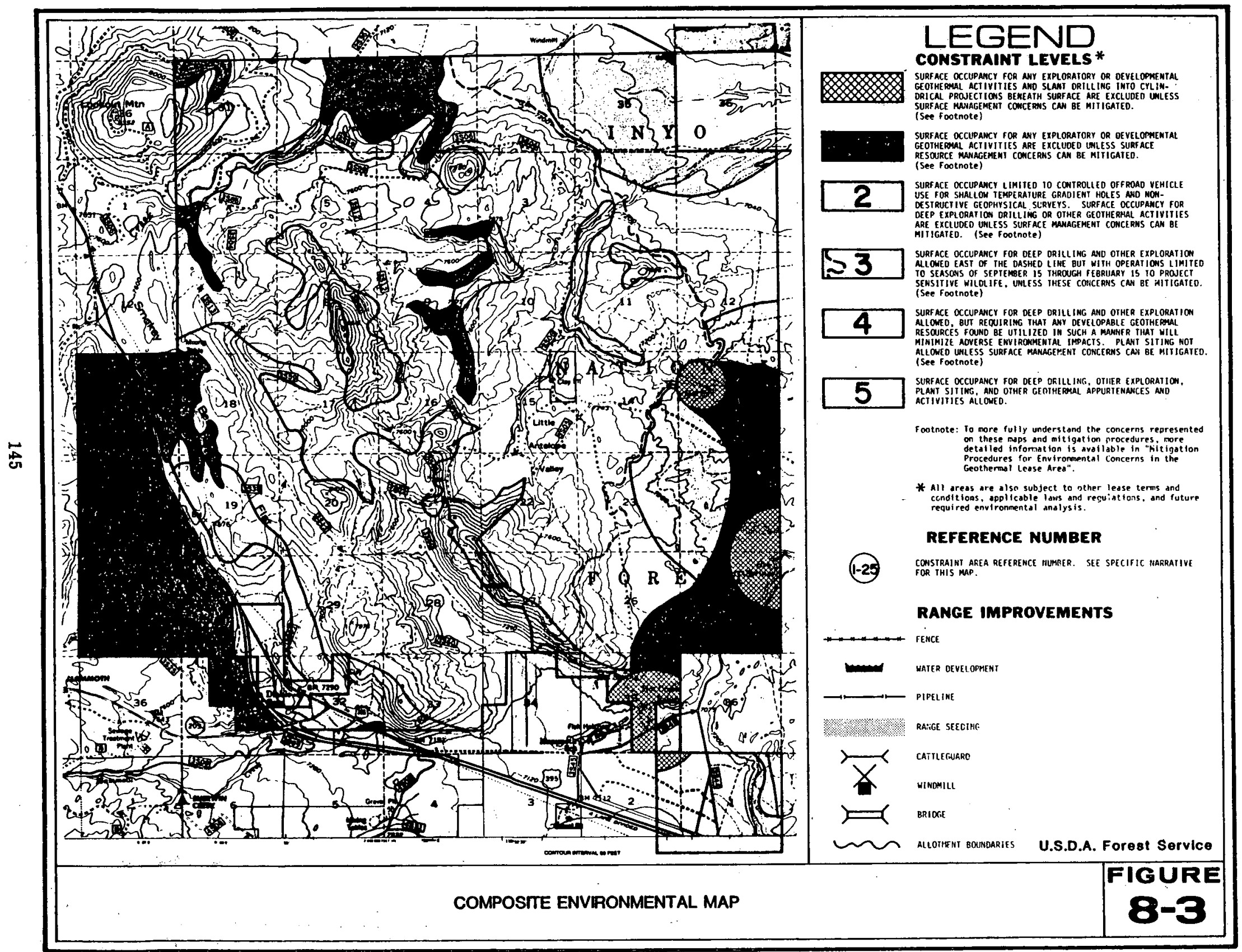


Table 8-1

COMPARISON OF PIPE REQUIREMENTS

FOR DELIVERING $1 \times 10^{8} \mathrm{Btu} / \mathrm{hr}$

$\begin{array}{lccc}\text { Water Delivery Temperature }\left({ }^{\circ} \mathrm{F}\right) & 200 & 300 & 400 \\ \text { Temperature Drop }\left({ }^{\circ} \mathrm{F}\right) & 50 & 150 & 250 \\ \text { Vapor Pressure (psi) } & 12 & 67 & 247 \\ \text { Flow Velocity (ft } / \mathrm{sec}) & 7 & 7 & 7 \\ \text { Flow Rate (gal/min) } & 4020 & 1330 & 790 \\ \text { Pipe Diameter (in.) } & 15.3 & 8.8 & 6.8 \\ \text { Delivered Energy (Btu/hr) } & 1 \times 10^{8} & 1 \times 10^{8} & 1 \times 10^{8}\end{array}$

Heat loss from the geothermal pipeline is dependent on the temperature difference between the geothermal fluid and the environment, the pipe dimensions, the presence and thickness of insulating material, the convection losses from air circulation over the pipe and the length of the pipeline. It is desirable to minimize the temperature difference, convection losses and the length of the pipeline to conserve usable heat.

Transport costs of geothermal brine decrease with increasing temperature because at higher temperatures the fluid contains a higher energy content per pound of delivered fluid. However, "there is a temperature above which the problems of piping water at a very high pressure are no longer compensated for by the additional heat in the water" (Beebee, 1979). Figure 8-4 shows some common types of pipeline construction used for hot water transmission in geothermal systems. Two items of concern for long distance transport are heat loss and internal and external corrosion. Pipeline construction is designed to minimize heat loss and corrosion problems.

Transmission pipelines in an open canal have the lowest initial costs of the pipeline constructions shown. These pipelines are exposed to climatic conditions which promote high heat loss and external corrosion. Normally the pipe construction includes an aluminum jacket over the pipe insulation to prevent moisture from reducing the effectiveness of the thermal insulation. Placement of the pipeline in trenches has environmental drawbacks including appearance and obstruction of the natural migration paths of wild animals. These issues are discussed in Section 8.8 in further detail.

The most widely used construction design involves underground insulated steel pipes protected from the corrosive effects of groundwater by a concrete duct. The duct can become very large for transmission systems with large pipe sizes and is responsible for a considerable part of the cost. This design reduces mechanical damage to the insulation and pipe, external corrosion and convection heat losses, however, the cost of this type of construction excludes it from consideration for the entire transmission route. The application for this particular type of construction in a transmission pipeline to Pine Creek would be for environmentally sensitive areas identified in an environmental assessment and road and river crossings.

The other pipe systems shown involve high excavation costs including trenching, refilling and other civil work associated with laying pipe underground. Unless it is specifically required to place the pipeline underground to mitigate environmental impacts or to obtain right-of-way permits, underground construction will not be used. 

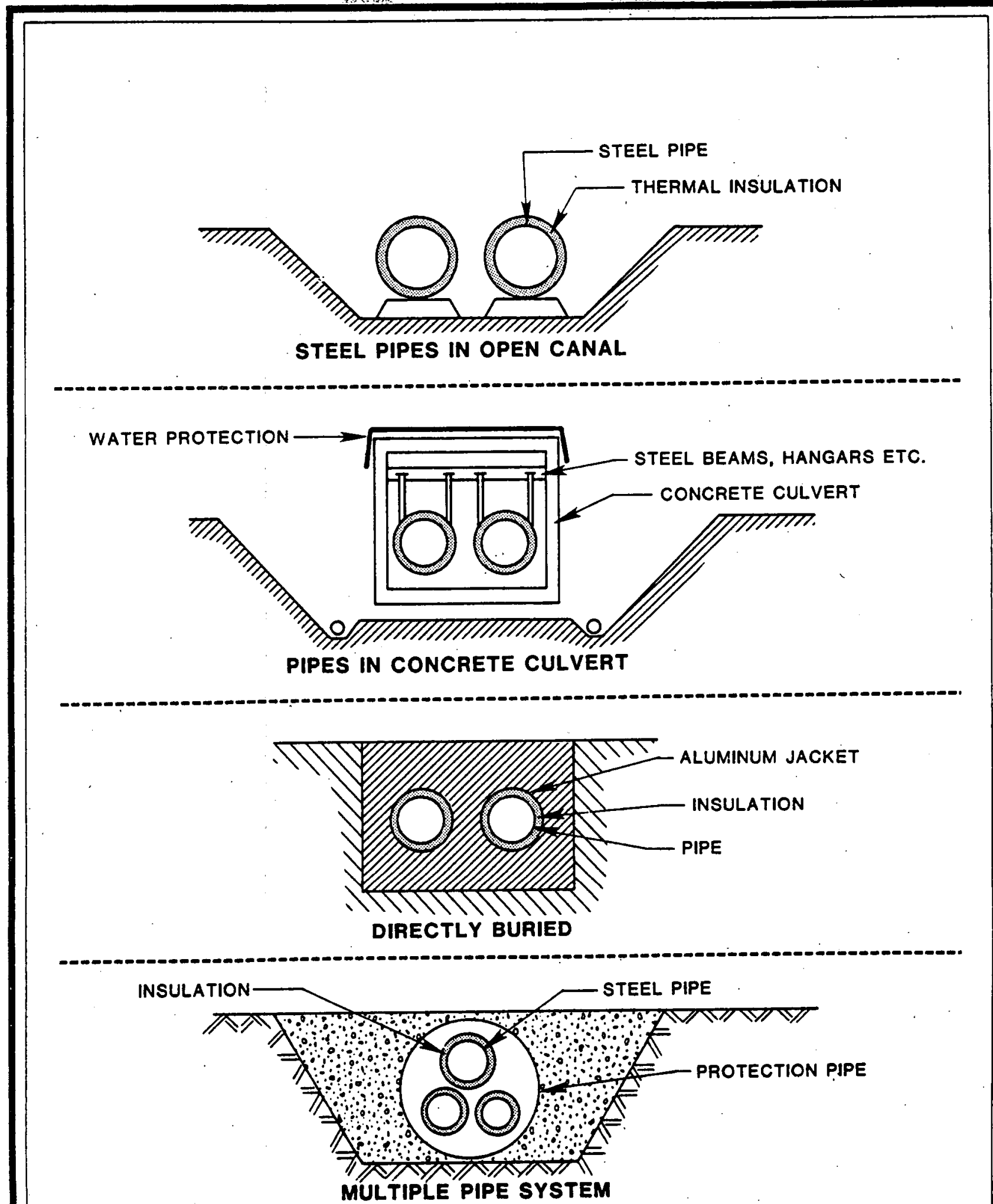

HOT WATER DISTRIBUTION SYSTEMS

FIGURE 8-4 
Transmitting energy by means of high temperature water requires special provisions for high temperature insulation, safety and pipeline expansion. The pipe schedule must include consideration of the pressure required for transport, temperature of the geothermal fluid, soil weight if the pipeline is buried, and the possibility of a vacuum developing if the pressure in the line drops below the vapor pressure of the geothermal fluid at any point.

\subsection{ENGINEERING EVALUATION OF LONG DISTANCE TRANSPORT}

The major engineering concerns for transmission of geothermal fluid from the Mono-Long Valley KGRA to the Pine Creek mill and processing plant are heat loss; power required for pumping to overcome function and gravity head, and formation of vapor pockets within the pipeline that may collapse and create "water hammer" if the fluid is not maintained under a pressure greater than the vapor pressure of the fluid.

\subsection{1 $\quad$ Heat Loss}

The value of geothermal brine is in the energy contained in the fluid as heat. Therefore, this property must be conserved. Pipeline construction must meet the requirements for thermal conveyance of the brine and limit thermal losses through effective insulation. There is evidence that computation of heat loss "rarely predicts heat loss accurately" (Beebee, 1979), but within these technical and economic constraints heat loss will be analyzed.

The general equation for heat transfer for circular pipes per unit length in a convection environment is:

$$
\overline{\mathrm{L}}=\frac{2 \pi\left\{\mathrm{T}_{\mathrm{i}}-\mathrm{T}_{\infty}\right\}}{\left[\frac{1 \mathrm{n} \mathrm{r}_{\mathrm{o}} \mathrm{r}_{\mathrm{i}}}{\mathrm{K}}+\frac{1}{\mathrm{r}_{\mathrm{o}} \mathrm{h}}\right]}
$$

where

$$
\begin{aligned}
& T_{i}=\text { fixed temperature of the inside of the pipe } \\
& T_{\infty}=\text { ambient temperature } \\
& r_{i}=\text { pipe radius } \\
& r_{0}=\text { outer radius of insulation } \\
& K=\text { conduction coefficient } \\
& h \quad=\text { convection coefficient }
\end{aligned}
$$

(J.P. Holman, 1976)

This formula predicts heat loss for a steady state system. 
Over the length of the transmission pipeline, the temperature of the geothermal fluid will drop as the brine loses heat to the environment. Because the internal temperature of the brine will not remain constant, this formula can be used to approximate heat loss for only short segments of pipe. This equation could be used in an iterative fashion to determine the exit temperature of the fluid with computer analysis.

The overall heat loss of the fluid in the transmission pipeline can be determined if a temperature drop between the inlet and outlet fluid is specified, with the following formula:

$$
q=m_{h} c_{h}\left(T_{h 1}-T_{h 2}\right)
$$

where

$$
\begin{aligned}
& q=\text { heat loss rate } \\
& m_{h}=\text { mass flow rate } \\
& c_{h}=\text { heat capacity of the fluid } \\
& T_{h 1}=\text { inlet temperature of fluid } \\
& T_{h 2}=\text { outlet temperature of fluid }
\end{aligned}
$$

If the temperature loss is restricted to 100 degrees over the length of the pipeline for a flow rate of $2000 \mathrm{gpm}$, the heat loss is approximately $1.0 \times 10^{8} \mathrm{Btu} / \mathrm{hr}$. If the energy extracted at the delivery end drops the temperature by $150 \mathrm{~F}$ to a minimum temperature of $100 \mathrm{~F}$ only 66 percent of the total heat content of the inlet fluid is used.

The general climatic conditions in both Mono and Inyo Counties include cold winters (see Section 2.2.2) which increase the potential of heat loss from the geothermal fluid at a time when the greatest demand will be placed on the geothermal system because of the additional space heating requirements. Thus the utilization increase in the winter will be offset economically by the decreasing percentage of usable heat extracted at the point of end use.

\subsubsection{Economics of Transport}

The estimated price for 34 miles of pipeline for 12 inch diameter carbon steel pipe with 2 inches of insulation installed in a pipeline trench is approximately $\$ 19.7$ million dollars. The prices associated with this distribution pipeline are shown in more complete detail in Appendix C. The cost of this pipeline exceeds the initial cepital investment required for a local geothermal well at Pine Creek so this project is not economically feasible, as maintenance and operation expenses for this project will exceed those of the initial project proposed for geothermal development at Pine Creek.

\subsection{PRELIMINARY JUSTIFICATION FOR DRILLSITE LOCATION}

The general area of the proposed drilling location near Casa Diablo Hot Springs is within the Long Valley caldera. Two deep wells have been developed within 
the caldera: one in the east half by Republic Geothermal, Inc. and the other in the west half by Magma Power Company. The Republic well was completed in the mid-1970s (1976?) and the Magma well in 1979. Specific data from these wells are proprietary. However, limited data are available concerning the Republic well. Because of the proprietary nature of corporate research justifying location of the leases for these wells, the drilling location proposed herein must be based on a temperature review.

Long Valley was included as a target area of the U.S. Geological Survey Geothermal Research Program and has therefore been the subject of many geologic, hydrologic, geophysical, and geochemical studies. The interim state-of-the-art culmination of this series of investigations has been the report by Sorey, Lewis, and Olmsted (1978): The Hydrothermal System of Long Valley Caldera, California.

The general consensus based on the relatively low temperatures measured throughout the drilled interval of the Republic well and previous geologic, geophysical and geochemcial data is that "The eastern 40 percent of the caldera is eliminated as an attractive hydrothermal resource, but that the western 60 percent continues to have major potential" (Sorey, et al., 1970. p. A4). Regional heat flow, seismic-retraction, and teleseismic analysis, and the occurrence of recent extrusive volcanism $(<10,000$ years) suggest that magma or partially molten rock exists under the western threefifths of the caldera at depths of 6 to $8 \mathrm{~km}$. The present-day hydrothermal system is dominated by hot water with equal temperatures at depth, estimated from the geochemistry of hot-spring waters, of about $210 \mathrm{C}$ to $280 \mathrm{C}$ (Sorey, et al., 1978, p. A56) within the upper one to 3 kilometers.

The Long Valley caldera is the locus of a regional gravity low (Pakisen, et al., 1964) and local gravity lows within the caldera correspond with the areas of thickest caldera filling (i.e., greatest depth to bedrock). Similarly, aberrations in aeromagnetic data occur within the caldera (Palcizer, et al., 1964). A dominant magnetic low is located near Casa Diablo Hot Springs. (Figure 8-5) which corresponds to an area of higher average reservoir temperature as modeled by Sorey, et al., 1978). Several test wells have been drilled into this anomalous portion of the caldera including the deep Magma Power well.

Wells drilled in the Casa Diablo Hot Springs area between 1959 and 1962 in T3S, R28E, Sec. 32, varied in depth from $174 \mathrm{~m}-247 \mathrm{~m}(571-810 \mathrm{ft})$ for the shallower wells and $324 \mathrm{~m}$ the deepest well. As of 1963 four of the wells had been productiontested (McNitt, 1963). Maximum observed temperature after several week shut-in varied from 172 to $178 \mathrm{C}$ in the shallower well and was $148 \mathrm{C}$ in the deep well. Wellhead conditions during production testing are shown in Table 8-2. As already mentioned data from the deep Magma well (>4500 ft) are proprietary.

Additional wells drilled into the aeromagnetically anomalous area near Casa Diablo Hot Springs have a higher probability of success than those drilled outside this area. The reason for this is the success of the aforementioned shallow wells. Those data have "continued" the viability of this portion of the western 60 percent of the reservoir whereas other areas outside the anomaly have not been contained. Therefore a drillsite location within the anomaly, close to Casa Diablo Hot Springs, has less of an exploratory aspect than one located elsewhere in the caldera. 


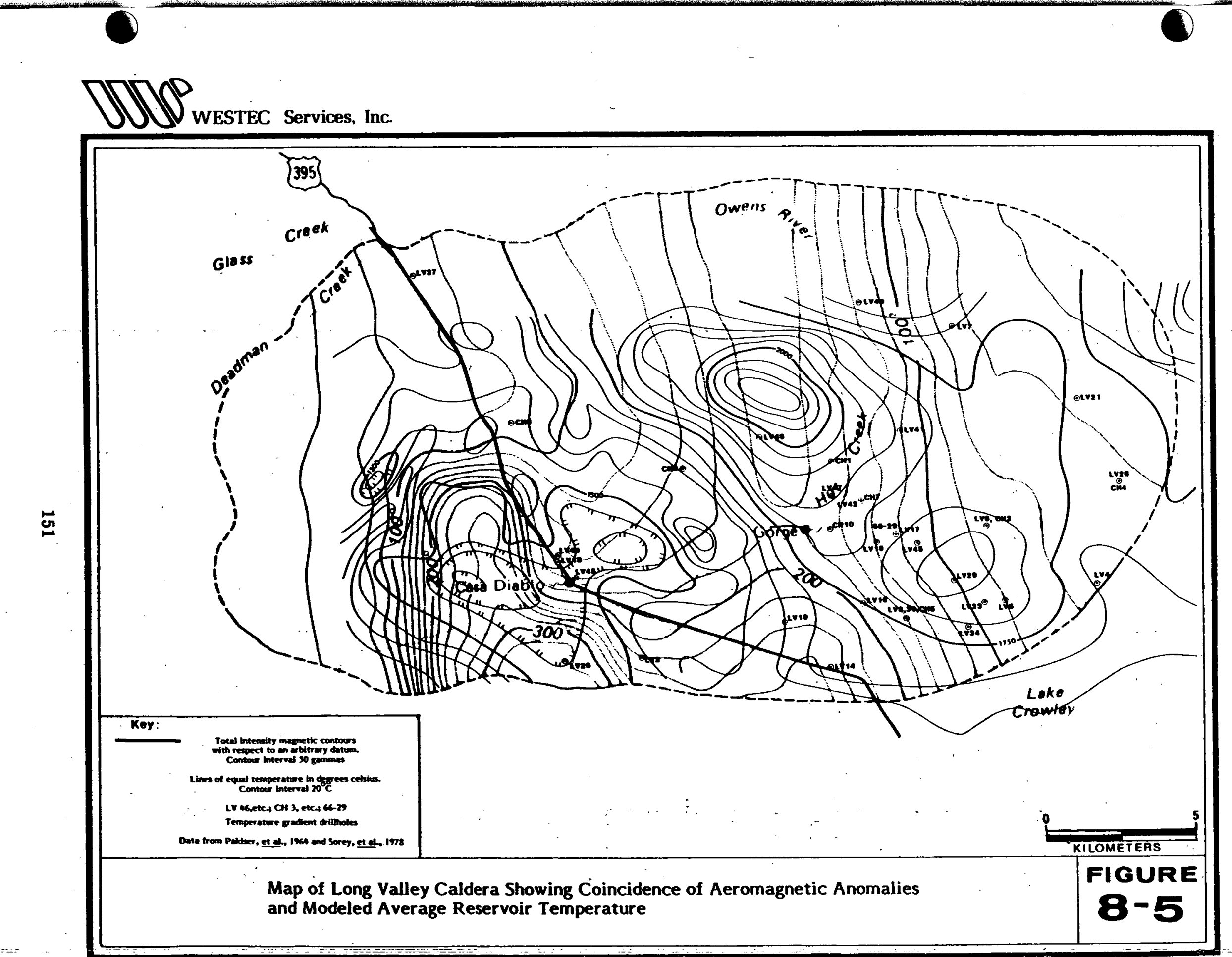


Table 8-2

WELLS IN MONO-LONG VALLEY KGRA

ENDOGENOUS 1

Location: T3S, R28E, Sec. $32,184 \mathrm{ft} \mathrm{N}, 655 \mathrm{ft} \mathrm{E}$,

Well data: from $W Q$ cor.

Depth - 192 m

Temperature - $178 \mathrm{C}$ @ 122 meters

Flow information $-69,300 \mathrm{lb} / \mathrm{hr}$ steam,

$473,000 \mathrm{lb} / \mathrm{hr}$ water at $39 \mathrm{psig}$ and

$148 \mathrm{C}$

$\mathrm{pH}-7.50$
Brine Data

Constituent

$\mathrm{SiO}_{2}$

$\mathrm{Ca}$

$\mathrm{Mg}$

$\mathrm{Na}$

K

$\mathrm{Li}$

Fe

Al

B

$\mathrm{Cl}$

$\mathrm{SO}_{4}$
Concentration 2 Trace 236

62

4

5

2

60

266

108

Sources: MeNitt 63, Witham 76

\section{ENDOGENOUS 2}

Location: T3S, R28E, Sec. $32,516 \mathrm{ft} \mathrm{N}, 431 \mathrm{ft} \mathrm{E}$, from $W Q$ cor.

Well data:

Depth - $247 \mathrm{~m}$

Temperature - $174 \mathrm{C}$ a 122 meters

Flow information $-45,000 \mathrm{lb} / \mathrm{hr}$ steam,

$233,500 \mathrm{lb} / \mathrm{hr}$ water at $38.5 \mathrm{psig}, 181 \mathrm{C}$

$\mathrm{pH}-\mathbf{8 . 6 1}$

Sources: McNitt 63, Witham 76

\section{ENDOGENOUS 3}

Location: T3S, R28E, Sec. $32,866 \mathrm{ft} \mathrm{N}$, $159 \mathrm{ft} E$, from $W Q$ Cor.

Brine Data

Constituent

$\mathrm{SiO}_{2}$

$\mathrm{Na}$

K

$\mathrm{Cl}$

$\mathrm{SO}_{4}$
Concentration 250 375 45 276 62
Brine Data

None Available

Well Data:

Depth - $174 \mathrm{~m}$

Temperature - $172 \mathrm{C}$ a maximum

Flow information $-19,000 \mathrm{lb} / \mathrm{hr}$ steam, $330,000 \mathrm{lb} / \mathrm{hr}$ water @ 30 psig and $157 \mathrm{C}$

Sources: MeNitt 63 , Witham 76 
Table 8-2 (Continued)

ENDOGENOUS 4

Brine Data

Location: T3S, R28E, Sec. $32,797 \mathrm{ft} \mathrm{N,} 884 \mathrm{ft} \mathrm{E}$, from $W Q$ cor.

Well data:

Depth $-156 \mathrm{~m}$

$\mathrm{pH}-6.50$

Temperature - Not Given

Noncondensable Gas in Steam - 0.87 percent

by weight 98.64 percent of gas by wt. is

$\mathrm{CO}_{2}, \mathbf{1 . 3 6}$ percent $\mathrm{H}_{2} \mathrm{~S}$

\begin{tabular}{cc} 
Constituent & Concentration \\
\cline { 2 - 2 } $\mathrm{SiO}_{2}$ & 200 \\
$\mathrm{Ca}$ & 4 \\
$\mathrm{Na}$ & 308 \\
$\mathrm{~K}$ & 32 \\
$\mathrm{Li}$ & \multicolumn{2}{c}{.3} \\
$\mathrm{~B}$ & 11 \\
$\mathrm{Cl}$ & 227 \\
$\mathrm{SO}_{4}$ & 96 \\
$\mathrm{H}_{2} \mathrm{~S}$ & 14 \\
$\mathrm{~F}$ & 20 \\
$\mathrm{NH}_{3}$ & \multicolumn{2}{c}{.1} \\
$\mathrm{CO}_{2}$ & 180 \\
$\mathrm{As}$ & \multicolumn{2}{c}{.2}
\end{tabular}

MAMMOTH 1

Brine Data

Location: T3S, R28E, Sec. $32,1240 \mathrm{ft} \mathrm{N}, 3043 \mathrm{ft} \mathrm{E}$, Constituent Concentration

Well data: from NQ cor.

Depth - $324 \mathrm{~m}$

Temperature - $148 \mathrm{C}$ a maximum

Flow information $-25,000 \mathrm{lb} / \mathrm{hr}$ steam,

$471,000 \mathrm{lb} / \mathrm{hr}$ water at $7.5 \mathrm{psig}, 132 \mathrm{C}$ pH $-\mathbf{8 . 0 0}$

$\begin{array}{cc}\mathrm{SiO}_{2} & 292 \\ \mathrm{Ca} & 30 \\ \mathrm{Mg} & \text { Trace } \\ \mathrm{Na} & 247 \\ \mathrm{~K} & 71 \\ \mathrm{Li} & 3 \\ \mathrm{Fe} & 4 \\ \mathrm{Al} & 1 \\ \mathrm{~B} & 49 \\ \mathrm{Cl} & 301 \\ \mathrm{SO}_{4} & 124\end{array}$

Sources: MeNitt 63, Witham 76 
8.7 Institutional Barriers Assessment

\subsubsection{Introduction}

Institutional barriers to geothermal exploration, development, and production in two areas within the Mono-Long Valley Known Geothermal Resource Area (KGRA) are described in this section. The proposed alternate drillsites, shown in Figure 8-6, are located in Sections 2 and 3 of Township 4 South (T4S), Range 28 East (R28E) and Section 32 of T3S, R28E in Mono County. As previously mentioned, these sites were selected on the basis of existing geological and environmental impact data. An additional consideration was the proximity of the proposed drillsites to Interstate 395, the most feasible corridor for the transmission pipeline.

Land in the proposed drillsite areas is primarily publicly-owned. Procedure for obtaining a federal geothermal lease on publicly-owned land will be described. Perhaps the most promising drillsite from a geological standpoint is the Casa Diablo Hot Springs area (Section 32, T3S, R28E), much of which is privately-owned. Institutional constraints to geothermal activity on private land are therefore reviewed. Finally, permits required for use of right-of-ways along existing roads are described. The purpose of this portion of the discussion is to identify potential institutional barriers associated with construction and use of the pipeline required for transportation of geothermal brine from the alternate drilling site to the mill site at Pine Creek.

\section{7 .2 \\ Obtaining Rights to Geothermal Resources on Land Administered by the} U.S. Forest Service

The land in Sections 2 and 3 of T4S, R28E is primarily publicly-owned. It is a part of the Inyo National Forest, which is administered by the U.S. Department of Agriculture through the Forest Service.

\subsubsection{Prospecting Permit}

To conduct initial exploration operations on U.S. Forest Service land, Union Carbide may apply to the Forest Service for a Prospecting Permit. Information pertaining to this permit is contained in the Forest Service Manual which interested parties may examine at Forest Service offices. The permit holder obtains a nonexclusive right to prospect for geothermal resources, including the authority to drill shallow temperature gradient holes. A Prospecting Permit does not entitle its holder to any preferential rights with respect to the federal geothermal leases described in Section 8.7.2.2 below.

Because a Forest Service Prospecting Permit allows the holder to disturb the land, in all likelihood the Forest Service must provide a review of the expected environmental impact of issuing the Permit. If, on the other hand, the operator only seeks permission to engage in activities which are characterized as "casual use", perhaps no environmental review will be required of the agency allowing such use.

To illustrate, the Bureau of Land Management (BLM) prevailed in a recent court case in which the issue was whether BLM must prepare an Environmental Impact Statement before allowing geothermal activities on BLM-administered federal land. 
(Sierra Club v. Hathaway, 579 F.2d 1162 (9th Cir. 1978)). The court defined "casual

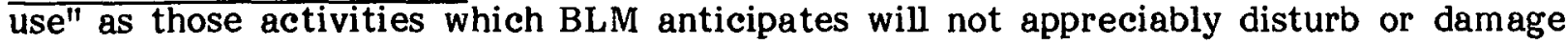
land, resources, and improvements.

\subsubsection{Geothermal Leasing}

a. The procedure for obtaining a geothermal lease for land administered by the U.S. Forest Service is specified in the Geothermal Steam Act of 1970 (30 U.S.C.A. § \$ 1001-1025) and regulations issued by the Department of the Interior pursuant thereto (43 C.F.R. Part 3200 (1979)). BLM has the authority to issue geothermal leases on national forest land administered by the Department of Agriculture through the Forest Service. Issuance of a lease is subject to consent of the Forest Service, which may also prescribe terms and conditions.

Section 1022(b) of the Act states that the right to develop and use geothermal resources located beneath lands owned by the United States may be acquired only in accordance with the provisions of the Act. The significance of this statute is that neither Union Carbide nor any other party may acquire rights to such geothermal resources by patenting existing mining claims, a process described in Section 6.3.1 of this report. The holder of a patented mining claim has greater surface and mineral estate ownership rights than a federal geothermal lessee.

The Act does provide for conversion of mining claims into geothermal leases if specified conditions are met. The right to apply for rights of conversion expired in June 1971, however. Geothermal Resources International, Inc. (GRI) acquired federal geothermal leases in Section 32, T3S, R28E - the Casa Diablo Hot Springs area of the Mono-Long Valley KGRA - by exercising conversion rights based on previously acquired placer mining claims. The validity of the leases was upheld in Getty Oil Company v. Andrus, 433 F. Supp. 1317 (1977).

Magma Energy, Inc. currently holds conversion rights under the conversion or "grandfather" rights provisions of the Geothermal Steam Act and regulations. These unexercised rights will allow Magma to acquire leases in the future. Magma may exercise its conversion rights by paying an amount which equals the highest bona fide bid submitted in a competitive lease sale. Magma's conversion rights are particularly important in light of the pending competitive lease sale discussed in Section 8.7.2.3 below. Magma was unable to perfect its conversion rights prior to this sale because BLM has not previously offered to sell the affected lease areas.

Under the Geothermal Steam Act, federal lands within a KGRA shall be leased to the highest responsible bidder in a competitive sale. The proposed alternate drilling site locations for the Pine Creek project are all located within the Mono-Long Valley KGRA. The term "KGRA", as defined in section 1002(e) of the Act, means:

An area in which the geology, nearby discoveries, competitive interests, or other indicia would, in the opinion of the Secretary, engender a belief in men who are experienced in the subject matter that the prospects for extraction of geothermal steam or associated geothermal resources are good enough to warrant expenditures of money for that purpose. 
BLM published a notice in the Federal Register in 1967 announcing its application to withdraw specified public lands from appropriation under public land laws, including the mining and mineral leasing laws (32 Fed. Reg. 4506 (1967)). The basis for the application for withdrawal was the presence of "favorable exploratory wells or favorable surface indications of geothermal anomaly, such as geysers, fumaroles, or thermal springs of high temperature or geophysically favorable extensions thereof." Each of the proposed alternate drilling sites for the Pine Creek project is located on land included in the BLM application for withdrawal. In fact, the application for withdrawal encompasses, in effect, the same area as the present MonoLong Valley KGRA. The KGRA designation for the Mono-Long Valley is therefore based on geological, as opposed to competitive interest criteria.

BLM determines, with the input of the Forest Service or other federal land management agencies, which, if any, areas within a given KGRA it will offer for leasing through a competitive bid sale. Although a prospective lessee may submit nominations to BLM indicating parcels upon which he wishes to bid, it is within BLM's discretion to determine whether to carry out the request. BLM must comply with its responsibilities of environmental review prior to conducting a lease sale. In the event that only one bid is submitted in a competitive bid lease sale, BLM may accept the bid and award a lease despite the competitive bid requirement if it determines that the bid is monetarily satisfactory. A recent statistical study indicates that the average dollar amount of bids received for leases in the Mono-Long Valley KGRA is higher than for any other KGRA, with the exception of the Geysers (Beeland, Ludington, and Schumann, 1979).

\section{b. Lease Duration}

The regulations state that the primary term of all leases shall be 10 years, with provision for no more than two additional terms to a maximum of 40 years each if geothermal steam is produced during the preceding term. It is unclear whether the lessee may renew his lease for an additional term if the purpose of the lease is production of geothermal fluid for direct heat application entailing no production of steam. If production of steam is required before a lessee can obtain a renewal, Union Carbide will be limited to a 10 year lease or must produce steam, even though production of steam has not been proposed for this project.

\section{c. Minimum and Maximum Acreage}

A federal geothermal lease may encompass no fewer than 640 acres unless geothermal resources will be used for non-electrical purposes or the applicant is exercising a conversion right. The former exception applies to the Pine Creek project. The maximum area available is generally 2560 acres per lease.

\section{d. The Diligent Exploration Requirement}

The regulations state that each geothermal lease must contain provisions requiring "diligent exploration" of the leased resources until such time as commercial quantities of geothermal fluid are produced (43 C.F.R. § 3203.5). A lessee's failure to explore diligently may cause termination of the lease. As discussed in Section 8.7.2.3 below, BLM scheduled a competitive bid sale on leases in the MonoLong Valley KGRA. Phillips Petroleum Co. filed a protest in an attempt to halt the 
sale. The basis for the protest was the "diligent exploration" requirement. The Forest Service inserted conditions in the leases which required lessees to collect representative data throughout the lease area in a timely manner. Conditions of this type obviously are beneficial to other potential geothermal developers who may receive data pertinent to making the decision where to drill. From the standpoint of the lessee who must perform the lease obligations, however, the conditions may impose a costly, timeconsuming, and perhaps useless burden. The lessee may wish to confine his geothermal operations to a small portion of the leasehold if that portion is sufficiently productive.

\section{e. Surface Management Requirements}

The regulations impose additional requirements upon federal geothermal lessees with respect to management of the surface estate affected by geothermal use (43 C.F.R. subpart 3204 ). The lessee is specifically required to comply with federal, state, and local standards regarding water and air quality. To operate under a geothermal lease at any of the proposed alternate drilling sites, Union Carbide must apply for a permit entitled "Waste Discharge Requirements" from the California Regional Water Quality Control Board, Lahontan Region. The regional board administers both the federal and California water quality laws.

A state agency also administers the air pollution laws promulgated by California and the federal government. The Great Basin Unified Air Pollution Control District has jurisdiction over the alternate drilling sites proposed for the Pine Creek project. Institutional barriers connected with water quality and air pollution control are discussed in greater detail in Section 6.4 of this report.

\section{f. Rentals and Royalties}

The regulations provide for payment of an annual rental of at least $\$ 1$ per acre. The rental rate will escalate in the sixth year of the lease. The lessee must pay a royalty of 10 to 15 percent of the value of the heat or energy which results from production under the lease and which is used by the lessee or can reasonably be used. The minimum yearly royalty is $\$ 2$ per acre, beginning with the year in which geothermal resources are produced in commercial quantities. The term "commercial quantities" means quantities which are sufficient to provide a return after all variable costs of production have been met (43 C.F.R. § 3200.0-5(j)(1979)).

\section{g. $\quad$ Bonds}

A federal geothermal lessee must obtain the following bonds:

A lease compliance bond in the amount of at least $\$ 10,000$, and

A bond in the amount of at least $\$ 5,000$ which indemnifies the lessee for damages to persons or property resulting from lease operations. 
h. California Division of Oil and Gas (DOG)

As discussed in Section 6.4.1 above, operators who intend to drill a geothermal well on privately-owned land in California must comply with the requirements of California Public Resources Code sections 3700-3776. These statutes and the attendant regulations are administered by the California Division of Oil and Gas. Although the statute does not expressly state that geothermal lessees operating on federally-owned land are exempt from these requirements, DOG's policy is not to assert jurisdiction over geothermal activity which takes place on federal lands within the state.

\section{i. Mono County Conditional Use Permit} ects located on federal lands.

Mono County does not require a conditional use permit for proj8.7.2.3 An Evaluation of Union Carbide's Potential for Obtaining a Federal Geothermal Lease

Congress enacted the Geothermal Steam Act of 1970 to authorize the Secretary of the Interior to issue leases for the development of geothermal resources beneath federal lands (Wharton, 1977). The statute gave the Secretary authority similar to that which he already had with respect to leases for development of oil and gas resources. Yet BLM has issued no geothermal leases for land which is administered by the U.S. Forest Service within the State of California (Beeland, Ludington, and Schumann, 1979). Nationwide, only two percent of Forest Service-administered land within KGRA's has been approved by the Forest Service as appropriate for leasing. As noted above, BLM canno't issue leases for geothermal resources located on Forest Service land unless the Forest Service consents.

Union Carbide and all prospective lessees should be encouraged, however, by the recent BLM announcement that a sale of leases within the Mono-Long Valley KGRA would be held on May 15, 1980. The significance of the lease sale announcement is that the Forest Service has consented to BLM's issuance of leases for Forest Service-administered land within the Mono-Long Valley KGRA. Although the sale was subsequently postponed until July and later postponed indefinitely following the filing of a protest by Phillips Petroleum Company, presumably the sale will occur when these difficulties are resolved. The substance of the protest is discussed in Section 8.7.2.2d above.

This consent may indicate that the Forest Service is now willing, on the basis of completed environmental assessments and area-wide plans, to allow geothermal leasing if the lease conditions and terms provide sufficient protection for the environment and for existing and projected land use.

8.7.3 Obtaining Rights to Geothermal Resources on Land Which is Privately Owned

If Union Carbide is unable to obtain a federal geothermal lease on Forest Service land due to the potential obstacles discussed above, the Casa Diablo Hot Springs 
area presents an attractive alternate drilling site. Much of the land in this area, which is located within T3S, R28E, Section 32 of Mono County is privately owned. Union Carbide could conceivably negotiate any of the following arrangements with Magma Energy, Inc., the principal owner:
a. Purchase of the surface and mineral estates.
b. Lease of geothermal resources.
c. Purchase of geothermal brine which has been pumped from the seller's wells.

If Union Carbide operated its own wells under situations a. or b. above, it would be required to obtain the appropriate permits from DOG, RWQCB and APCD, all of which are described in Section 6.4 above. In addition, compliance with the requirements imposed by the Mono County Planning Department would be necessary.

\subsubsection{Obtaining a Right-of-Way for the Geothermal Brine Transportation Pipeline}

Existing road right-of-ways are the most feasible locations for the pipeline required for transporting geothermal brine from the proposed alternate drilling sites to the Union Carbide tungsten mine and mill at Pine Creek (Figure 8-6). All of the alternate drill sites are close to U.S. 395. The proposed pipeline corridor would follow the highway until it reaches Round Valley. At this point the pipeline corridor would be located on a paved county secondary road which originates at U.S. 395, runs through the town of Rovana, and ends at the mill site.

\subsubsection{U.S. 395}

The California Department of Transportation (Caltrans) has authority to permit encroachment on the U.S. 395 right-of-way. A party seeking a permit must submit a permit application accompanied by drawings or plans to the appropriate Caltrans district office. The Bishop office has jurisdiction over the segment of U.S. 395 relevant to the Pine Creek project. The district office will then send the application to various agencies for review. Caltrans must comply with the requirements of the California Environmental Quality Act (CEQA). Although a portion of U.S. 395 southeast of Mammoth Lakes is designated a scenic highway, Caltrans currently has no general prohibition against new visual encroachments in this area. The agency would therefore consider each application on a case-by-case basis.

\subsubsection{Inyo County Paved Secondary Road}

Permission to lay a pipeline along the paved county secondary road which extends from U.S. 395 through Rovana to the tungsten mill site at Pine Creek is obtained from the Inyo County Road Department, Independence California, by applying for an Encroachment Permit. County Planning Commission review is required. The county must fulfill its responsibilities under CEQA, perhaps by contributing to a combined environmental review document compiled by state, local, and federal agencies involved with the Pine Creek geothermal project. A major factor in the Road Department's decision regarding the application would be the effect of the pipeline on the county's obligation to keep snow off the road. 
If Caltrans and/or Inyo County refused to grant Union Carbide permission to place the pipeline in the road right-of-ways, an alternate course of action would be for Union Carbide to negotiate with the various parties who own the property bordering the roads. Although a small portion of the adjoining land is privately owned, the major portion is in the public domain under the jurisdiction of the U.S. Forest Service, BLM, or the Los Angeles Department of Water and Power.

The BLM-administered land along the proposed transmission corridor is classified as "withdrawn". The purpose of the withdrawal, in most cases, is to protect the watershed of the Los Angeles water supply. BLM, however, has the authority to determine whether a proposed use of withdrawn land is permissible. One important factor is whether the proposed use is compatible with the purpose of the withdrawal. BLM would in all likelihood approve a geothermal brine transportation pipeline only if the permit terms and conditions imposed on the permit holder the burden of protecting the watershed against spillage. An additional consideration would be BLM's tentative policy of allowing no further visual encroachment on the withdrawn land bordering U.S 395 below Lake Crowley.

\subsubsection{Summary and Conclusions}

Land ownership at the proposed alternate drillsites was researched. It was determined that most of the land is publicly-owned under the administration of the U.S. Forest Service. Some acreage in the Casa Diablo Hot Springs area, however, is privately-owned. Governmental controls imposed on geothermal operators drilling on Forest Service and privately-owned land were discussed, with emphasis on the procedure for obtaining a federal geothermal lease. After evaluating Union Carbide's potential for acquiring such a lease, it was concluded that, although there are currently no federal geothermal leases on Forest Service land in California, such leases might become available in the immediate future.

Finally, land ownership of the road right-of-ways proposed as the location for the geothermal brine pipeline was researched. The procedure for obtaining permission to lay a pipeline along these right-of-ways was then discussed. Potential institutional barriers associated with the location of the pipeline were identified. It is unclear whether BLM, Caltrans, and Inyo County would issue the permits which Union Carbide must obtain in order to lay the pipelines. Relevant to the decision is the effect of the pipeline on the following:
a. The Los Angeles water supply watershed.
b. Scenic areas where additional visual encroachment is discouraged.
c. Snow removal responsibilities of relevant government agencies.

Because it is not economically feasible to place the pipeline beneath the right-of-way surface, the viability of the alternate drillsites depends to a great extent on the decisions reached by the relevant land surface management agencies. 
The environmental assessment of the proposed alternative geothermal development identifies potential environmental constraints which should be further analyzed before implementation of the alternative scheme. The constraints study involves a synthesis of available literature and interviews. The study area includes the region from Casa Diablo Hot Springs near Mammoth, south along U.S. Highway 395 to the Pine Creek Tungsten Mine location (see Figure 8-6). The majority of the existing conditions analysis for the Pine Creek Mine area as well as for portions of the study area further north is contained in Section 7 of this report, entitled Environmental Factors. Further existing conditions for the study area not described in Section 7 are contained in this section. Environmental factors include climatology and air quality, water quality, biological resources, noise, geological resources, visual quality/aesthetics, land use compatibility and cultural resources.

The assessment identifies general environmental constraints related to the proposed alternative. Specific impacts would need to be identified when project plans become available.

\subsubsection{Climatology and Air Quality}

\subsubsection{Study Area Characteristics}

Climate: A major portion of the study area is located below the eastern slopes of the Sierra Nevada Mountains in the Long Valley/Owens Valley region. A portion of the study area extends west from the Owens Valley up to about the 8000 foot elevation at the Pine Creek Tungsten Mine. The mountains have a major effect on area climate: the mountainous portions receive the greatest amount of precipitation, and snow accumulations vary with exposure, topography and ground cover. The lower slopes and valley are arid (USDA, 1979).

The Bishop U.S. Weather Service office at the Municipal Airport, approximately 2.5 miles east of Bishop, provides local climatological data for the Bishop area. This information may be found in Section 7.2.5, Climatology and Air Quality.

Average January and July temperatures for the Bishop and Bridgeport areas, and precipitation data for both areas as well as higher elevations on the east slopes of the Sierras, are presented below:

\begin{tabular}{|c|c|c|c|c|c|}
\hline & & $\begin{array}{l}\text { Aver } \\
\text { empe }\end{array}$ & $\begin{array}{l}\text { Daily } \\
\text { ure (E) }\end{array}$ & & $\begin{array}{l}\text { Precipitation } \\
\quad \text { (inches) }\end{array}$ \\
\hline & Jat & ary & & & Annual \\
\hline & Min. & Max. & Min. & Max. & \\
\hline $\begin{array}{l}\text { Bishop } \\
\text { Bridgeport }^{(1)}\end{array}$ & $\begin{array}{c}20.5 \\
8\end{array}$ & $\begin{array}{l}53.6 \\
26\end{array}$ & $\begin{array}{l}55.7 \\
60\end{array}$ & $\begin{array}{l}97.5 \\
83\end{array}$ & $\begin{array}{l}24.4 \\
11 \\
31 \text { (high elevations) }\end{array}$ \\
\hline
\end{tabular}

Sources: $\quad{ }^{(1)}$ NOAA, no date

(2) Jamin, 1980 


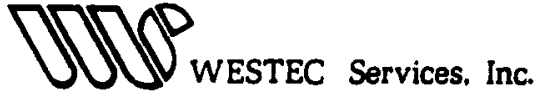

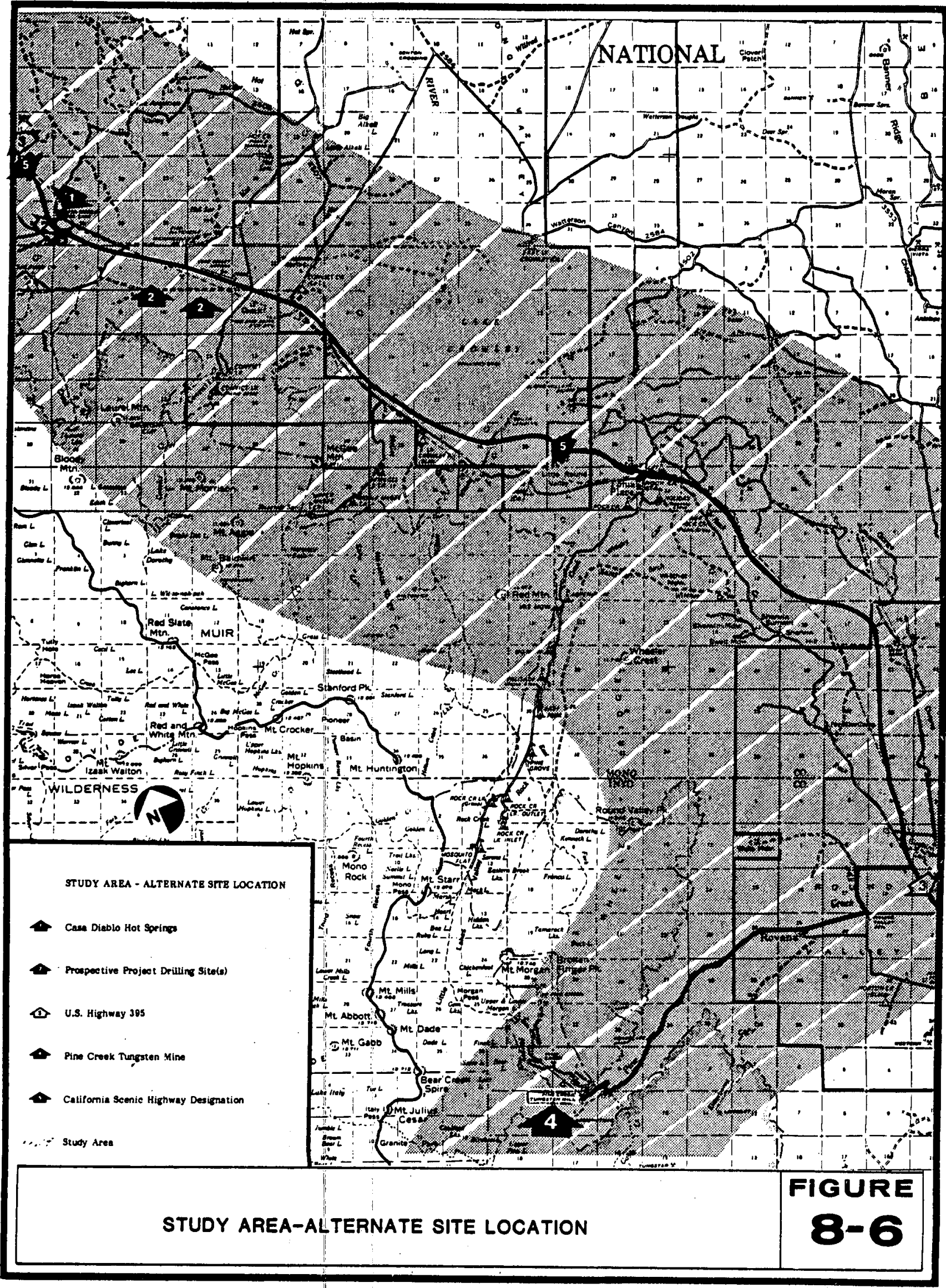


Snow accumulates along U.S. Highway 395 during the winter months and averages 8 to 10 feet during a normal season. Caltrans keeps Highway 395 open during the entire season which requires use of either rotary or normal snowplows to remove the snow from the road and deposit it off and adjacent to the road (Paglia, 1980).

Air Quality: The Great Basin Air Pollution Control District (GBAPCD) provides air quality monitoring for the entire study area. Suspended particulate matter is the primary air pollution problem in the Great Basin APCD. The potential for serious air pollution problems from excessive concentrations of oxidants, hydrocarbons and nitrogen oxides is remote for most areas within the Basin (GBAPCD, 1976). Further air quality information is contained in Section 7.2.5.1, and on Tables 7-4 and 7-5.

A recently installed carbon monoxide monitor at Mammoth Lakes has proven to be faulty, therefore, data from this station is of no value (Fryxell, 1980). Thus, air quality measurement data in the area are quite limited at the present.

Hydrogen sulfide $\left(\mathrm{H}_{2} \mathrm{~S}\right)$ and sulphur dioxide $\left(\mathrm{SO}_{2}\right)$, pollutants common to areas of geothermal development, would be suspected in the region of the potential drilling site. Site-specific monitoring is usually required in such areas to determine potential impacts from geothermal development to the existing ambient air quality:

Those and other air quality concerns were identified through numerous meetings and sessions conducted by the Forest Service with the public. Pollutants emitted from gases and their associated odors, and dust raised by construction were the major identified concerns. However, the Forest Service's Environmental Assessment, Leasing of National Forest Lands for Geothermal Exploration in the Long Valley Caldera, states that

"The escape of small quantities of noxious and odorous gases must be regarded as an unavoidable consequence of geothermal development. Burning of debris produced in clearing for access roads and facility development will result in some smoke pollution. Dust control and watering can effectively control the dust raised along access roads and around earth-moving operations. However, there will be some dust in spite of the preventive measures."

In order to determine air quality impacts created by well drilling and pipeline construction, ambient air quality measurements should be conducted along the study area before construction begins.

\subsubsection{Constraints to Development}

The drilling operation could occur in an area of naturally occurring hydrothermal activity, therefore, pollutants and odors generally associated with geothermal activity are currently present, especially near Casa Diablo Hot Springs and other hot springs along Hot Creek. Air measurements of this area before construction should 
include particulates $\mathrm{SO}_{2}$ and $\mathrm{H}_{2} \mathrm{~S}$. Drilling and pipeline construction would increase area dust levels and, depending on wind conditions, could carry construction-related dust to other areas of the valley. Potentially necessary grading and clearing along U.S. Highway 395 would raise dust levels along this route and may affect the visual experience of passing motorists as well as residents near the highway. Monitoring should be conducted during the construction phase to determine amounts of construction-related pollutants. Mitigation is possible for construction related particulates, however, $\mathrm{SO}_{2}$ and $\mathrm{H}_{2} \mathrm{~S}$ emissions may only be partially controlled by scrubbers on emission stacks. Because geothermal activity is proposed for this region through area plans, geothermal-related pollutants have been anticipated. However, dust created by grading and clearing along U.S. 395 for pipeline placement should be mitigated in order to reduce dust concentrations in a region where particulates already exceed current air quality standards.

The cumulative impact of all emission sources is anticipated to be small, with the most serious impacts to aesthetics in the surrounding wilderness areas. The impacts to air quality are neither unique nor excessive and would not act as a constraint to the proposed geothermal project.

Geological Resources

8.8.2.1

\section{Study Area Characteristics}

The study area is situated in the Long Valley/Owens Valley region and continues up into the eastern escarpment of the Sierra Nevada Mountains at the Pine Creek Tungsten Mine. Long Valley is a large, elliptical shaped collapsed caldera which is called the Long Valley Caldera. Information relevant to the Pine Creek mine area is contained in Section 7.2.4.1.

The study area is underlain with (1) Quaternary basalt and rhyolite near Casa Diablo, (2) Quaternary alluvium (sediments) southeast to Whiskey Creek, (3) preQuaternary granitic rocks and Quaternary glacial till south to near Sherwin Grade, Pleistocene Bishop Tuff and Quaternary sediments south and west to near the Pine Creek mine where pre-Quaternary granitic rocks underlay much of the mine area.

The Hilton Creek fault runs generally in a north-south direction approximately 1.5 miles from the west end of Crowley Lake (see Figure 8-7). This active fault forms a 3600-foot escarpment at the mouth of McGee Creek and bisects the Known Geothermal Resource Area (KGRA). It is believed that movement at this fault created the recent earthquake activity near Mammoth. From previous well drillings, it has been determined that the hydrothermal resource to the east of the fault is cooler and that the potential for hydrothermal production to the west of the fault is greater due to a hotter resource (Sorey, et al., 1978). The Sierra Nevada fault zone, the Wheeler Crest fault and several other unnamed faults exist near or in the study area (Jennings, 1975). In addition to the faulting in the region, Long Valley is located on the west edge of the extensive Ventura-Winnemucea seismic zone, a trend of continuously high seismic activity over 375 miles in length. One of the main zones of activity is located along the Owens Valley. 


\subsubsection{Constraints to Development}

Placement of the drilling site near the Casa Diablo area or further south to the perimeter of the KGRA and west of the Hilton Creek fault would be within the identified hydrothermally productive region. However, in order to provide access of the geothermal fluid via pipeline to the Pine Creek mine with minimal ground alteration, the drilling site should be near U.S. 395, a previously graded and altered linear region.

The potential exists for shearing of the well casing at the drillsite or breaks to the pipeline along the entire route from the previously identified geologic hazards creating ground movement. The U.S. 395 right-of-way is generally away from the eastern escarpment of the Sierra Nevada Mountains; therefore, if the pipeline were located along this route, rockfalls or landslides on the east faces would not contact it in most locations. However, mitigation should be implemented in any location which may be close to a potential landslide or rockslide condition.

Another potential constraint would be induced seismicity from fluid reinjection during production level operations. Subsidence and fault displacement are not considered probable near the Casa Diablo area or along U.S. 395 to the Pine Creek mine. The location of the drilling site and the pipeline route should be proposed for areas which avoid the previously described potential hazards areas such as faults, rockfalls and landslides.

As stated previously in Section 7.2.4.3, earthquake-induced groundshaking is not known to have caused serious problems with drilling rigs in the past, even in the seismically active Imperial Valley. A properly designed and installed rig should be able to withstand the highest probable earthquake event.

A special stipulation identified in the Environmental Assessment, Leasing of National Forest Lands for Geothermal Exploration in the Long Valley Caldera concerning the area hydrologic system states that "The Lessee (of a drilling site) shall develop and implement a study of the effects of geothermal exploration and development within the lease area on the hydrologic system of the area including hot springs. Methodology for the study shall be acceptable to the Area Geothermal Supervisor and the Forest Supervisor. Copies of the final draft of the study shall be given to the Area Geothermal Supervisor and Forest Supervisor for review and comment. The document (together with comments) will be used as part of any future environmental analysis." (USDAFS, 1980). This study and related considerations should be consulted during further project planning.

\subsubsection{Water Quality}

\subsubsection{Study Area Characteristics}

The study area includes many creeks and their tributaries which drain into various watersheds, most of which are utilized for the Los Angeles water supply. Major creeks in the study area include Mammoth Creek, Hot Creek, Convict Creek, McGee Creek, Hilton Creek, Whiskey Creek, Rock Creek and Pine Creek. Forest and mountains cover about 40 percent of Mono County; chaparral and sagebrush cover another 40 percent. The remainder of the area is desert and grasslands (Hahn, 1973). In Inyo 
County, 18 percent of the area is mountainous, 10 percent is Owens Valley, and the remaining 72 percent is desert (Gibson, 1980). Heavy snowfall in the mountain regions is the major contributor to water resources and feeds the many streams and lakes located within the county. Crowley Lake, near the study area, serves as a reservoir for the Los Angeles Water Department (Hahn, 1973).

As human use in the watershed areas increases, the amounts of bacteria and contamination in the area creeks and lakes also increase. Some streams in the study area are frequently utilized for recreation purposes which contributes low amounts of bacteria and sediment to the streams. In addition, the infusion of geothermal fluids degrades the quality of the surface waters by introducing concentrations of arsenic, fluoride and boron. These concentrations are currently very low and insignificant (USGS, 1976). Generally, the surface water quality is considered good to excellent for both existing and potential uses. Most of the surface waters are of moderately soft bicarbonate type with low dissolved mineral content and are nearly neutral in pH. Exceptions to these general conditions are areas such as portions of Hot Creek and Mammoth Creek, which are influenced by local hot springs resulting in higher mineral content and increased temperatures (USDAFS, 1980).

The Hot Creek drainage, near the Casa Diablo Hot Springs area, is a unique aquatic ecosystem. The warm waters provide an abundance of benthic organisms which assure a stable and large diet for trout. Hot Creek remains ice-free during the winter and provides feeding and nesting areas for many species of waterfowl and shorebirds. The riparian zones and vegetative growth provide habitat for many other species of birds and herbivores. In addition, the warm springs are also one of the favored recreational locations for visitors to the Mammoth area (USDAFS, 1980).

Rock Creek, which follows a large part of the study area, also provides excellent riparian habitat, however, it has little vegetative cover and is not used extensively by recreationists. The stream offers poor habitat for fish because of the steep gradient in various locations which, when coupled with the natural process of erosion, contributes large amounts of sand and fine gravel to the stream bottom.

\subsubsection{Water Management}

As described previously in Section 7.2.1.1, the entire study area is located in the Lahontan Region of the California Regional Water Quality Control Board (SWRCB). The U.S. Forest Service is under contract with SWRCB to complete water quality management practices, or Best Management Practices (BMP) as developed in accordance with Section 208 of the Clean Water Act. Through the BMP, the Forest Service provides the board with information necessary to carry out water quality programs (USDAFS, 1978).

The Inyo National Forest region of the Forest Service has developed within their Environmental Assessment, Leasing of National Forest Lands for Geothermal Exploration in the Long Valley Caldera, a constraint analysis of watersheds for a portion of the study area from the Casa Diablo area south along U.S. 395 approximately 4 miles. The Constraint Levels identified in this report propose surface occupancies and types of drilling to be allowed within identified sensitive watershed areas (USDAFS, 1980). This analysis should be referred to when determining the exact drilling location 
and pipeline route. In addition, the Forest Service is currently monitoring all identified potential problem streams in the Inyo National Forest and has not encountered any long range or severe problems. The risk factors used in analysis include sedimentation, and chemicals and bacteria induced from both humans and wildlife (Sapousek, 1980). Further contact with the Forest Service should be made when the exact pipeline location is known to determine the existing condition of all streams and watersheds which could potentially be affected.

\subsubsection{Constraints to Development}

Construction of the drilling site, pipeline and pipeline route may contribute sedimentation to the streams which could potentially affect the water quality of the watersheds. Because the previously described Hot Creek drainage is a unique and sensitive ecosystem, additional caution should be exercised in order to avoid adverse effects from the geothermal project. If the pipeline is located next to the U.S. 395 right-of-way, minor, if any, grading is anticipated. However, additional grading and clearing may be necessary activities which could contribute higher amounts of sediment than currently enter Rock Creek which runs adjacent to Highway 395 over much of the study area. No known sources of chemicals or bacteria are associated with grading and clearing, therefore, a degradation of existing water quality would be expected only from sediment contributions.

A potential impact at the drilling site location and along the pipeline is possible from pipeline breaks or spills which would discharge geothermal fluids onto the adjacent land. An analysis of the quality of the resource fluids should be conducted prior to any construction in order to determine adequate water quality degradation prevention schemes. Potential impacts are expected to be similar to those associated with many of the water-dominated geothermal reservoirs: thermal pollution, hydrogen sulfide, heavy metals, etc. Contamination of the watershed by such an occurrence may be prevented by placement of concrete trenches beneath the pipelines to contain any spillage, or, in areas where the collapse of snow drifts may cause a pipeline break, the pipeline may be enclosed within special tunnels.

In summary, the water quality in the study area is considered good, and certain precautions should be taken at time of project implementation to assure continuation of existing water quality. These precautions include: (1) consultation with the Forest Service and use of their pre-developed constraints to determine the existing water quality of the streams in the project location; (2) ongoing monitoring of all streams which could be potentially affected by drilling site and pipeline construction or pipeline laying created by grading, clearing and spillage of geothermal fluids; (3) analysis of the geothermal fluid to determine what pollutants could be introduced within the streams; and (4) use of tunnels and concrete trenches along the pipeline where possible breaks or spills may contaminate a water source.

\subsubsection{Biological Resources}

\subsubsection{Study Area Characteristics}

Flora: The majority of the study area is located in the Long Valley/Owens Valley region of Mono and Inyo Counties. Vegetation is as diverse as the terrain 
because of climatic conditions and elevation differences. Long Valley is characterized by typical high desert communities such as sage scrub, bitterbrush and rabbit brush. Pinyon-juniper woodlands cover the adjacent hills and Jeffrey pines grow at higher elevations, usually between 7000 and 8000 feet. Other predominant vegetation types, in addition to forest and range, include grassland and cultivated pasture, meadows, riparian woodlands and brushland. The vegetation in the study area near the Pine Creek Tungsten Mine is described in Section 7.2.2.1.

Various rare and endangered plant species have been recorded in the vicinity of the study area and generally along the east slope of the Sierra Crest. None of these plant species are expected to occur along the previously graded and disturbed areas adjacent to U.S. 395. These species include Mono milk vetch (Astragalus monoensis), Long Valley milk vetch (Astragalus johannis-howellii), and Mono buckwheat (Eriogonum ampullaceum) (CNPS, 1980). A survey of the proposed project location should precede any site development to evaluate the biological resources of this area and determine if any sensitive or rare and endangered species exist which would be affected by project construction.

Fauna: Terrestrial animals common to the study area include deer, coyotes, squirrels, chipmunks, mountain lions, pine martens and black bear. Further information regarding large terrestrial animals in the Pine Creek area is contained in Section 7.2.2.1. Birds commonly found include red-tailed hawks, sage grouse, vesper sparrows, woodpeckers, chickadees, nuthatches and goshawks. Waters in the area contain populations of tui chubs, three spine stickleback, mosquito fish, endemic Owens sucker, and rainbow, brook and brown trout. Seven species are listed as endangered, threatened, rare or sensitive by either the U.S. Fish and Wildlife Service, California, or the U.S. Forest Service. These are: (1) the American bald eagle (Haliaeetus leucocephalus)-endangered, (2) Owens tui chub (Gila bicolorsnyderi)-endangered, (3) wolverine (Gulo luscus)-rare, (4) prairie falcon (Falco mexicanus)-sensitive, (5) osprey (Pandion haliaetus)-sensitive, (6) golden eagle (Aquila chrysaetos)-sensitive, and (7) goshawk (Accipter gentilis)-sensitive (USDAFS, 1978).

Further studies of the current faunal level in this area as well as in the entire study area should be conducted in order to evaluate the status and migratory patterns of the existing resource. It is assumed that the deer herds and bighorn sheep would not migrate east of U.S. 395, however, this must be confirmed to evaluate potential impacts from placement of the pipeline across a migratory path. The pipeline would probably not be larger than 16 inches in diameter and, therefore, the wildlife could cross under or over it if it were close to the ground. However, placement would most likely be above ground with a concrete trench underneath with protective tunnel insulation in designated geologically hazardous areas.

\subsubsection{Constraints to Development}

Before an environmental report is submitted concerning biological resource impacts from the drilling and pipeline project, floral and faunal surveys should be conducted to determine the presence of sensitive or rare and endangered species. Research into the migratory patterns of the area herds should be conducted either through direct observation or communication with proper authorities on the subject. Mitigation measures should be proposed as necessary, and may include pipeline camouflage or possible realignment of a proposed route. 
The Forest Service has developed a constraint level map identifying sensitive areas which correspond to proposed levels of geothermal development. The constraint levels propose types of geothermal development allowed for each sensitive area identified. The identified sensitive areas in and adjacent to the study area fall under Level 1 constraints because they are a part of the highly productive Hot Creek fisheries area (Hot Creek has been designated by the State of California as a Wild Trout Stream). Level 1 constraints state "Surface occupancy for any exploratory or developmental geothermal activities are excluded unless surface resource management concerns can be mitigated" (USDAFS, 1980). This report should be referred to before the drilling location and pipeline route are implemented and before future environmental reports are submitted. In addition, the Forest Service's Land Management Plan for the MammothMono Planning Unit should be consulted in order to follow applicable goals and policies.

\subsubsection{Land Use Compatibility}

\subsubsection{Study Area Characteristics}

Land Ownership: The majority of land within the study area is publiclyowned and included in the Inyo National Forest system and the Bureau of Land Management's (BLM) Bishop Resource Area. A large percent of BLM land has been withdrawn for special purposes, primarily for the protection of the watershed for the benefit of the City of Los Angeles. The remainder of land is owned by the City of Los Angeles and private interests.

The Union Carbide Tungsten Mine, mill and related facilities are located at the westernmost end of Pine Creek Canyon at about the 8000 foot elevation and dominate the land use in that area. Land use in this area is described in Section 7.2.7.1.2. As Pine Creek Road continues in an easterly direction, it eventually intersects U.S. Highway 395, where the study area continues north toward the drillsite location, approximately 25 miles, to the Casa Diablo area.

Land uses in the Owens/Long Valley area have historically consisted primarily of grazing and timber production. Principal natural resources include commercial timber, grazing lands, minerals, geothermal energy and water. Timber production from Inyo National Forest and grazing currently are the major land uses in the area. Though minerals are an identified natural resource, mineral production is not a major land use activity. Potential geothermal resources exist and the major potential production area is designated by the Known Geothermal Resource Area (KGRA) status. The City of Los Angeles exports water from Crowley Lake via aqueduct to southern California.

No major urban centers exist in the study area, however, Bishop is located about 9.3 miles south of the southern study area perimeter and Mammoth Lakes is located approximately 4 miles west of the Casa Diablo area.

Recreation has been a principal land use activity in the MammothCrowley Lake region. Skiing and other snow-related activities, camping, backpacking, mule packing, fishing and hunting are the principle recreation activities found in this area. 
Land Management: The U.S. Forest Service defines the land use management goals and policies for the portions of the study area located in the Inyo National Forest. As previously mentioned, the Land Management Plan for the Mammoth-Mono Planning Unit describes the land use goals and policies for the planning area which covers 695 square miles of the Inyo National Forest. The entire Inyo National Forest, including the wilderness areas, is covered by the Forest Service's 1972 Multiple Use Plan for Inyo National Forest. All plans are being updated into the Forest Plan which is expected to be completed by 1983 . The Forest Plan will supersede all current plans and will be the major planning document at that time.

Portions of the study area on BLM land fall under the management of this agency. The BLM has "Land Use and Management Recommendations" for their lands in the study area which includes the Bishop and Long Valley management areas. Management concerns include many environmental considerations such as geothermal exploration and development.

The City of Los Angeles and privately-owned lands are not managed by any management plans other than those county general plans and associated elements relative to each location. Inyo County is presently updating their General Plan of 1968 and has completed the Scenic Highway and Seismic Safety Elements. The Safety Element should be adopted by September 1980 and the Conservation and Open Space Element by November 1980 . A separate management plan entitled Monoplan covers the Mammoth area east to Casa Diablo Hot Springs. The agencies participating in formulating this plan include the County of Mono, the U.S. Forest Service, Inyo National Forest, Mammoth Ranger District, the California State Department of Transportation (Caltrans), Bishop, and the Western Federal Regional Council. Management goals and policies were developed for this plan after extensive environmental base studies were conducted.

The California State Department of Transportation administers actions along the U.S. Highway 395 right-of-way. Through the California Scenic Highway Program, Caltrans has the responsibility of administering and coordinating this program and for officially designating highways as state or county scenic highways. Caltrans' report, "The Scenic Route, Guide for the Official Designation of Scenic Highways," describes actions which would be necessary to implement this highway designation.

\subsubsection{Constraints to Development}

Placement of the pipeline adjacent to U.S. 395 and possible drilling near Casa Diablo Hot Springs presents no major land use constraints because (1) geothermal development has been anticipated to occur in the Casa Diablo area, and (2) because grading and land use disturbance have previously occurred along U.S. 395. Use of the linear right-of-way (though the pipeline would be placed outside of but immediately adjacent to the highway right-of-way) would present no further land use disturbance in this area. Caltrans indicated that a potential concern would be in having a pipeline with toxic substances placed adjacent to the highway right-of-way, and that hot geothermal fluid would present no problem (Paglia; 1980). However, a pipeline with hot fluid may present a safety hazard along certain accident-prone portions of the highway such as high speed areas or hazardous turns. If the pipeline were to be placed above ground and adjacent to the highway right-of-way, potential safety impacts should be 
mitigated where necessary. Mitigation could be achieved by installation of a heavy duty pipeline buffer in accident-prone areas. The land use and management plans for the study area should be consulted in order to avoid sensitive areas. Various easements, leases and right-of-ways would be required in order for the pipeline to cross over public and private lands. These requirements are discussed in Institutional Barriers, Section 8.7.

\subsubsection{Visual Quality/Aesthetics \\ 8.8.6.1 Study Area Characteristics}

The Long Valley/Owens Valley region lies east of the Sierra Nevada Mountains. The dominant landforms in this region of outstanding natural beauty are the Sierra Nevada Mountains, Long Valley and Owens Valley, which set the background for the area's visual character. The barren and winter snow-covered peaks and valley floor with the vegetation patterns, water features and man-made features characterize the area. Vegetation patterns vary from coniferous forest to open range land to desert sage scrub. Water features include the Owens River, Convict Lake, Crowley Lake and other small area streams (described in Water Quality, Section 8.8.3). Man-made features usually contrast markedly with the natural environment and include U.S. 395 and Bishop as well as other small residential developments. The overall aesthetic quality of the area is considered high with well-known, striking scenery.

The study area includes the western end of Pine Creek Canyon on the eastern side of Wheeler Crest, described in Section 7.2.6.1. The study area continues north along U.S. 395 approximately 25 miles to near the Casa Diablo Hot Springs area. Elevations along the highway vary from 4500 feet near Bishop to 6200 feet along Sherwin Grade and eventually to 7300 feet near Casa Diablo. Vegetation varies from desert sage scrub to Jeffrey pines with the northern study area being more alpine in nature and the Bishop area being more desert-like. Vistas of the Sierra Nevadas to the west are always present and vistas of the White Mountains to the east can be seen from much of the highway south of Sherwin Grade.

The Pine Creek Tungsten Mine and mill and other portions of the study area, including the road continuing east to Rovana, are visible from the surrounding portions of the canyon which are higher in elevation than the mine and canyon road. Therefore, portions of the John Muir Wilderness including a hiking and riding trail and portions of the Inyo National Forest would have views of the study area. As the road continues towards U.S. 395 and once this intersection is reached, the topography is relatively flat. This is also true as the study area continues north toward Casa Diablo. Much of the study area is either flat or bounded by small hills to the east and west, therefore, only a few scattered residences and travelers along adjacent roads would have views of the area.

A portion of U.S. 395 in the study area is included in the State Scenic Highway System and includes approximately 9 miles from the southern end of Lake Crowley to just north of Casa Diablo. In order for a highway corridor to remain scenic, the County of Inyo Scenic Highway Element states that "certain minimum land use and development standards should be observed. The standards proposed by this element are applicable for both state and county scenic highway corridors, and are purposely in 
conformance with state guidelines for 'official' Scenic Highway designation." The land use and development standards include guidelines for (1) Land Uses, (2) Signs and Outdoor Advertising, (3) Utility Lines, (4) Earthwork, (5) Plant Material, (6) Property Maintenance, and (7) Historical Preservation. The guidelines for Earthwork operations state that "Grading or earth-moving operations should be done with a minimum of disturbance... Vegetative cover, preferably native to the area, and other screening devices should be provided to hide scars and blend with the natural landscape..." Therefore, certain amounts of development are anticipated along Scenic Corridors, however, these guidelines should be followed in the development process. In addition to the Inyo County Scenic Highway Element, there is a Regional Scenic Highway Element which states regional goals and policies and applies to both Inyo and Mono Counties. However, this document served basically as a guideline for specific county policies, and each County Scenic Highway Element should be used in preference to this. Mono County is currently preparing their Scenic Highway Element (Jamin, 1980).

The Forest Service has acknowledged that visual disturbances are created by man-made features of geothermal development including the drill rigs, emissions, clearing and grading, clearing lanes, industrial complexes and related transmission lines. The Forest Service has developed a Constraints Levels Map for a portion of the study area which presents sensitive visual resource areas recommended for protection. The constraints identify levels of development allowed within the identified visually sensitive areas (USDAFS, 1980).

\subsubsection{Constraints to Development}

Geothermal production and construction equipment located in the study area would create visual disturbance to the Casa Diablo area, south along U.S. 395 and west to the Pine Creek area. However, geothermal development and related visual impacts have been anticipated for the Casa Diablo area. The Forest Service has stated in their Environmental Assessment, Leasing of National Forest Lands for Geothermal Exploration in the Long Valley Caldera that

"Geothermal facilities can, to some extent, be screened or blended into the background. Because of the extensive network of pipelines, transmission lines, roads, and buildings, however, it is unlikely that all such installations can be blended into the surroundings. Steam plumes from cooling towers likewise cannot be hidden, particularly in winter."

A visual quality objective (VQO) inventory for the Geothermal Management Zone is contained in the Forest Service's Land Management Plan for the Mammoth-Mono Planning Unit. A VQO is a desired level of visual excellence based on physical and sociological characteristics. It refers to the degree of acceptable alteration of the characteristic landscape. These VQO's should be referred to during project planning. Possible clearing and grading along U.S. 395 would create impacts to the previously identified Scenic Highway characteristics. In addition, passing motorists would be exposed to views of construction activities which would disturb vistas west to the Sierra Nevada Mountains. These impacts would be short term and could be partially mitigated by watering of graded surfaces to keep the dust down. However, long term 
affects to visual quality would occur from placement of a pipeline along U.S. 395 which would disturb views toward the mountains. The pipeline, placed above ground and shielded by a concrete trench underneath and protective tunnels in certain geologically hazardous areas, would be obvious to passing motorists and presents the major visual quality constraint.

\subsubsection{Noise}

\subsubsection{Study Area Characteristics}

Existing sound levels in the study area are established by both natural and man-made sources. The most significant man-made source is traffic along U.S. 395. At a distance of 50 feet from the highway, sound levels may increase from low natural background noise to as high as 90 to $95 \mathrm{~dB}(\mathrm{~A})$ (decibels on the A-weighted sound level scale) when a large truck passes. Sound levels along U.S. 395 at a distance of 50 feet during normal conditions would vary from about $55 \mathrm{~dB}(\mathrm{~A})$ to about $70 \mathrm{~dB}$ (A) (USEPA, 1972). Noise levels near the Pine Creek Tungsten Mine would emanate from general industrial activity and are described in Section 7.2.3.1. Natural noise sources in the entire study area include animals, wind and occasional thunderstorms. Additional noise would emanate from persons using the recreational land uses, however, this noise would also be low.

\subsubsection{Constraints to Development}

The noise effects from the well drilling phase would be noticeable, yet temporary. Construction of the well drilling site and the pipeline would also be noticeable with the major source being large vehicles. The Forest Service has stated in the Environmental Assessment, Leasing of National Forest Lands for Geothermal Exploration in the Long Valley Caldera that "Higher than present noise levels must be regarded as unavoidable around geothermal operations. The adverse impacts to wildlife, recreation, grazing livestock and adjoining landowners are also considered unavoidable..." However, this would occur mainly from the construction phase and would be temporary. No significant noise levels are anticipated from activities related to pipeline placement along U.S. 395. Once the well is drilled, the geothermal operation and transportation would be relatively quiet. Thus, no major constraints are anticipated.

\subsubsection{Cultural Resources}

The undertaking suggested by the Union Carbide Company regarding utilization of geothermal resources from Casa Diablo Hot Springs, Mono County, California would have a potential for impacting cultural resources. Until a field survey is conducted on the proposed project area, potential impacts to, or adverse effects upon, cultural resources cannot be fully determined. At the earliest possible stage during project planning, and prior to any land modifications at any project location, an intensive cultural resource survey would be required (King, Morat to and Leonard, 1973). This inventory would serve to identify and evaluate all extant cultural resources within or immediately adjacent to the subject project areas.

The initial stages of development of the inventory would require compilation of all existing cultural resource data pertaining to the project area. At a minimum the following agencies and institutions would need to be contacted. 
- Archaeological Research Unit, University of California, Riverside

- Office of Historic Preservation, Sacramento, California

- Bureau of Land Management, Bishop Area Office

- U.S. Forest Service, Bishop, California

- Native American Heritage Commission, Sacramento, California

- California Department of Transportation (Caltrans), Sacramento, California

- Department of Parks and Recreation, City of Los Angeles, California

- University of California, Berkeley

- Mono County Historical Society, Bridgeport, California

- University of California, Los Angeles, California

- San Diego State University, San Diego, California

- Eastern California Museum, Independence, California

- Bishop Museum and Historical Society, Bishop, California

All phases of fieldwork would be closely coordinated with the U.S. Forest Service, Bureau of Land Management, State Historic Preservation Office, Native American Heritage Commission and California Department of Transportation (Caltrans). Fieldwork would consist of an on-foot field survey conducted by professional archaeologists of the entire project area to include drilling sites, pipeline corridors, access roads, equipment staging areas, and other areas where any land modifications would take place. All sites would need to be accurately recorded on proper site records, and assigned State of California numbers. Each cultural resource would be photo recorded and mapped. The fieldwork phase would be followed by analysis and interpretation of each site in view of their significance and eligibility for inclusion in the National Register of Historic Places.

Site-specific management recommendations would be prepared and would comply with regulations governing the Protection and Management of Cultural Resources embodied in the following Federal legislation:

- Antiquity Act of 1906

- Historic Sites Act of $\mathbf{1 9 3 5}$

- National Historic Preservation Act of 1966 (Amended 1974)

- Executive Order 11593 and Federal Regulations 
- 36 CFR 60: National Register of Historic Places: Criteria for Statewide Historic Surveys and Plans

- 36 CFR 63: Procedures for Requesting Determinations of Eligibility to the National Register of Historic Places.

- 36 CFR 65: Recovery of Scientific, Prehistoric, Historic, and Archaeological Data: Procedures for Coordination and Notification.

- 36 CFR 66: Recovery of Scientific, Prehistoric, Historic, and Archaeological Data: Methods, Standards and Reporting Requirements.

36 CFR 800: Procedures for the Protection of Historic and Cultural Properties.

In addition to the above regulations, compliance with Public Law 95-341, the American Indian Religious Freedom Act, is required. Local Native American groups and individuals would need to be directly consulted, and allowed to participate in the planning process. Assistance in identifying and contacting these groups and individuals would be requested from the Native American Heritage Commission, Sacramento, California.

The Final Report documenting the inventory of the proposed project would follow the format required by the California State Office of Historic Preservation, and would be distributed for review to representatives of all concerned agencies.

\subsection{CONCLUSION}

Although no significant environmental or institutional impacts were noted for geothermal development in the Mono-Long Valley KGRA, the heat loss encountered with long distance transportation would require an inlet temperature of greater than $350 \mathrm{~F}$ in order to extract at least 66 percent of the heat energy that enters the pipeline. The installed costs of a 34 mile long pipeline would exceed 19.7 million dollars. This initial front end capital investment exceeds that of the initial project (drilling at the mill site) proposed for the Union Carbide tungsten complex and will therefore not be economically feasible. It is important to realize that although transportation distance and costs are prohibitive in this case, geothermal energy can replace significant energy demands in mineral processing. Geothermal direct heat applications continue to expand, and the Mono-Long Valley KGRA may become an area for commercial development. 


\section{R.EFERENCES}

Beebee, John, February 1979, Cost of Hot Water Transport under DOE Contract EY-77-C-08-1540.

Beeland, Gene V.; Ludington, Judith A.; and Schumann, Estelle; Statistical Characterization of the Federal Geothermal Leasing and Permitting Program, WAPORA, Ine. for U.S. Department of Energy (DOE) under Contract No. ET-78-C01-3114, Final Report, January 1979.

Brewer, George, 1980, Union Carbide Corporation, personal communication, January.

California Native Plant Society (CNPS), 1980, Inventory of Rare and Endangered Vascular Plants of California, Special Publication No. 1 (2nd Edition), April.

California Public Resources Code sections 3700-3776.

Fryxell, Charles, 1980, Great Basin Unified Air Pollution Control District, Bishop, California, telephone communication, July 1, written communication, February 21.

Geothermal Steam Act of 1970 (30 U.S.C.A. Sections 1001-1025).

Getty Oil Company v. Andrus, 433 F. Supp. 1317 (C.D. Cal. 1977).

Gibson, Diane, 1980, County of Inyo Planning Department, telephone communication, July 17.

Hahn, Wise and Associates, Inc., 1973, Open Space and Conservation Elements of the General Plan for Mono County, California, June 19.

Inyo, County of, 1974, Title 19, Geothermal Resource Development, January.

Inyo, County of, 1979, Scenic Highway Element of the County Inyo General Plan, February 13.

Inyo, County of, 1979 , Seismic Safety Element of the County of Inyo General Plan, April 24.

Jamin, Terri, 1980, County of Mono Planning Department, telephone conversation, July 16.

Jennings, C.W., 1975, "Fault Map of California with Locations of Volcanoes, Thermal Springs and Thermal Wells," California Division of Mines and Geology, California Geologic Data Map Series, Map No. 1.

King, Thomas F., Michael Moratto and N. Nelson Leonard III, 1973, Recommended Procedures for Archaeological Impact Evaluation, University of California, Archaeological Survey and Society of California Archaeology. 
Leys, Art, 1980, U.S. Forest Service, Inyo National Forest Office, Bishop, California, telephone communication, April 1, July 16.

Margen, Peter, 1979, Large District Heating Systems, Newer Techniques, Applications to U.S. Region.

McNitt, J.R., 1963, Exploration and Development of Geothermal Power in California: California Division of Mines and Geology, Special Report 75.

Meader, J.T., May 1976, MTUS Technology Evaluation - Thermal Energy Conveyance under HUD Interagency Agreement No. IAA-H-40-72, ERDA 40-333-72; Contract No. W-7405-ENG-26.

Monoplan Associates, 1973, County of Mono Planning Department, Bridgeport, California, Monoplan Studies for Mammoth, Phase 2: Environmental Background Reports.

Paglia, Larry, 1980, California Department of Transportation (Caltrans), telephone communication, July 16.

Pakiser, L.C., M.F. Kane, and W.H. Jackson, 1964, Structural Geology and Volcanism of Owens Valley Region, California. A Geophysical Study: U.S. Geol. Survey, Prof. Paper 438.

Rice, Robert L., March 1980, Environmental Assessment: Leasing of National Forest Lands for Geothermal Exploration in the Long Valley Caldera.

Rundel, Philip W., David J. Parsons, Donald T. Gordon, 1977, "Montane and Subalpine Vegetation of the Sierra Nevada and Cascade Ranges," Terrestrial Vegetation of California, edited by Michael G. Barbour and Jack Major, John Wiley \& Sons, New York.

Sepousek, Ollie, 1980, U.S. Forest Service, Forest Superintendent Office, Bishop, California, telephone communication, July 10.

Sierra Club v. Hathaway, 579 F.2d 1162 (9th Cir. 1978).

Sorey, M.L., R.E. Lewis, and F.H. Olmsted, 1978, "The Hydrothermal System of Long Valley Caldera, California," Geohydrology of Geothermal Systems, Geological Survey Professional Paper 1044-A, U.S. Government Printing Office, Washington.

Stefferude, Jerry, 1980, U.S. Forest Service, White Mountain Ranger District, Bishop, California, telephone communication, April 1.

U.S. Department of Agriculture, Forest Service, 1979, Pacific Southwest Region, "Water Quality Management for National Forest System Lands in California," ("Section 208" Plan), April.

U.S. Department of Agriculture, Forest Service (USDAFS), 1978, Pacific Southwest Region, Final Environmental Statement, Land Management Plan for the Mammoth-Mono Planning Unit, July. 
U.S. Department of Agriculture (USDA), 1971, "Environmental Survey Report, Stage 1, Pine Creek Tungsten Mine, Union Carbide Corporation," February 10.

U.S. Department of Commerce, National Oceanic and Atmospheric Administration (NOAA), no date, "Local Climatological Data, 1978, Bishop, California."

U.S. Department of the Interior, Bureau of Land Management (BLM), 1979, Bishop, California, Form 6671-5, "Aquatic Habitat Inventories," September.

U.S. Department of the Interior, 1973, Final Environmental Statement for the Geothermal Leasing Program, Volume II of IV.

U.S. Department of the Interior, Bureau of Land Management (BLM), no date, Bishop, California, Form 6671-5, "General Remarks and Narrative Report - Watershed Condition."

U.S. Department of the Interior, Bureau of Land Management (BLM), no date, "Bishop Management Area, Land Use Management Recommendations," and "Long Valley Management Area, Land Use Management Recommendations."

U.S. Environmental Protection Agency (USEPA), 1972, Noise Pollution.

U.S. Geological Survey (USGS), 1976, "Environmental Analysis Prepared for Three Proposed Deep Exploration Holes on Lease CA-963, Republic Geothermal, Inc., Long Valley, California," Menlo Park, California.

Wharton, James C., "Federal Law on Geothermal Resources," Geothermal Resource Development: Laws and Regulations, Lawrence Livermore Laboratory for U.S. Department of Energy (DOE) under Contract No. W-7405-ENG-48, 1977.

Woodward-Clyde Consultants, 1977, Environmental Data Statement, Exploratory Geothermal Well Drilling Operations at Long Valley, California, June.

32 Fed. Reg. 4506 (1967).

43 C.F.R. Part 3200 (1979). 


\section{SECTION 9}

\section{ALTERNATES TO GEOTHERMAL DEVELOPMENT AT PINE CREEK}

\section{$9.1 \quad$ INTRODUCTION}

The economics of replacing conventional fuel sources with geothermal energy in mineral processing appear to be favorable if the processing is located near a geothermal resource. Specifically, for the two approaches discussed for geothermal uses at the Pine Creek tungsten complex, expenses associated with drilling to a depth of $5.7 \mathrm{~km}$ for a marginal resource or transporting geothermal fluid 34 miles from a known geothermal resource area were too high and caused the project to be uneconomical. Union Carbide's tungsten mill and processing plant spends over two million dollars per year on fuel oil and electricity, so the potential for energy savings is tremendous.

Considering current price escalations of fuel oil and electricity, a fuel that is not dependent on conventional energy sources is highly attractive. If a milling and processing plant for unrefined ore was located within or in close proximity to a geothermal resource or other alternative energy source, fuel substitution should be economically viable for the highly energy intensive mineral processing. Discussed below are some options for the use of geothermal energy and hydroelectric energy for refining tungsten and other minerals.

\subsection{HYDROELECTRIC POWER AT PINE CREEK}

The potential of hydroelectric power generation at the Pine Creek tungsten complex was investigated to determine theoretical and expected power output for a micro-hydro system. The initial evaluation was based on runoff from the water clarifier which discharges filtered mine water at 6000-8000 gpm. The elevation gradient in the immediate vicinity of the Pine Creek complex could be used to increase the static head and therefore power production, if the runoff water was piped to a lower elevation before power is extracted from the stream in the hydroelectric turbine. This proposal for hydroelectric power would require little or no stream modifications and minimal construction costs. The absence of a dam and reservoir would also eliminate serious environmental and institutional issues that may delay project implementation in this sensitive forest area.

\subsubsection{Theoretical Power}

The power output is dependent on what portion of the available elevation gradient is used. The theoretical power that could be produced by a hydroelectric turbine was evaluated for a number of elevation drops from the Pine Creek mill site using the formula $\mathrm{P}_{\mathrm{TH}}=62.4 \mathrm{lb} / \mathrm{ft}^{3} \times \mathrm{Q} \times \mathrm{h}$ (Alward, 1979). A rough estimate for the theoretical power proauction and a cost etimate of the penstock for the associated power output is shown in Figure 9-1.

\subsubsection{Expected Power}

Conversion of the power in the water resource to mechanical shaft work will be less than predicted by theory as the equipment is less than 100 percent efficient. 


\section{arop}

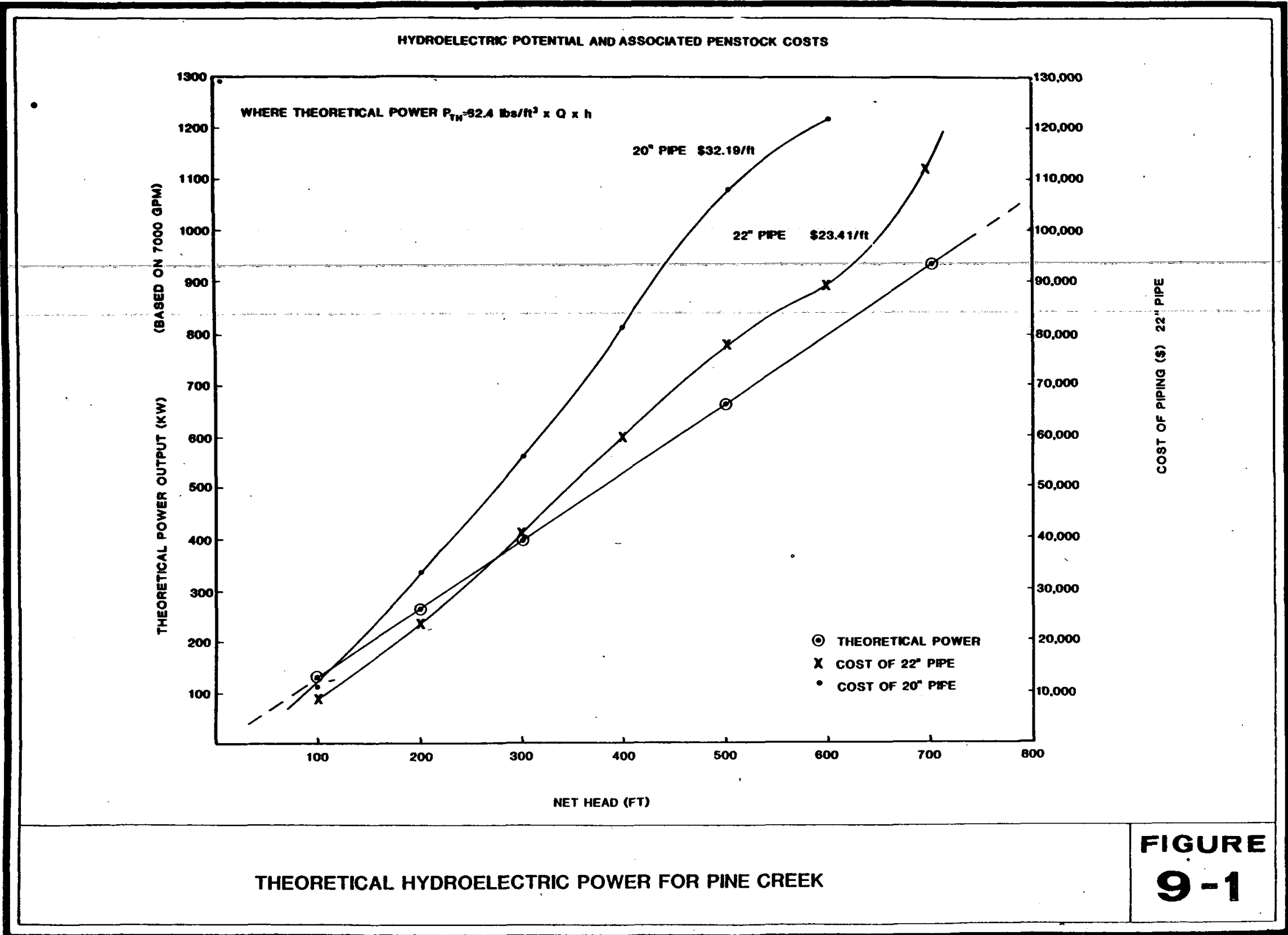

THEORETICAL HYDROELECTRIC POWER FOR PINE CREEK

9-1 
Water turbines are fairly efficient (75-85 percent) in converting the energy in the flowing water into mechanical or electrical energy. Water wheels have typical efficiencies of less than 50 percent. Other losses are incurred when transmitting power from the water wheel or turbine to a generator, alternator, or some mechanical system. Typical efficiencies for hydroelectric generation sytems range from 50-75 percent with the higher overall efficiencies occurring with the high speed, high head turbines.

The expected power output for an electrical generation facility with 65 percent overall efficiency is shown in Figure 9-2. Using data from the topographical map supplied by Pine Creek personnel, a rough estimate was made of the piping required to obtain elevation drops at specific points. A first order approximation for piping costs at the site-specific elevation drops is plotted on Figure 9-2, allowing a comparison of the power produced versus the cost of penstock piping.

The available water flow without construction of a reservoir at the Pine Creek complex is unusually low for commercial power production. However, a custom built turbine and generator might be obtained if further investigation warrants the cost of such a unit. Electricity produced in this manner could reduce the power consumption of the tungsten mining complex during peak load hours.

\subsection{ALTERNATE SITES FOR GEOTHERMAL ENERGY IN MINERAL PROC- ESSING}

Geothermal direct use can be applicable if used in other types of mineral processing. One possible direction of focus is the processing of minor metals, such as beryllium, cesium, lithium, rare-earth minerals, tantalum and tungsten. These metals are all either individually mined or byproducts or coproducts of other minor metals; none is associated with a major metal. The mining of these minor metals is usually associated with smaller firms (i.e., corporate assets of \$5-50 million) (Brooks, 1965), and smelting is not generally required for mineral separation. Minerals that may have potential for geothermal energy substitution in their processing are discussed below.

\subsubsection{Mineral Processing}

a. Beryllium

Present treatment of the beryllium concentrate consists of reaction with an acid to form a water soluble salt, concentration of the salt by fractional crystallization; reduction of the salt to the metal.

b. $\quad$ Cadmium

1. Fractional distillation of the blue powder and refractionation of the distillate.

2. Solution of the oxide in acids and precipitation of the metal chemically or electrolytically. 


\section{onop}

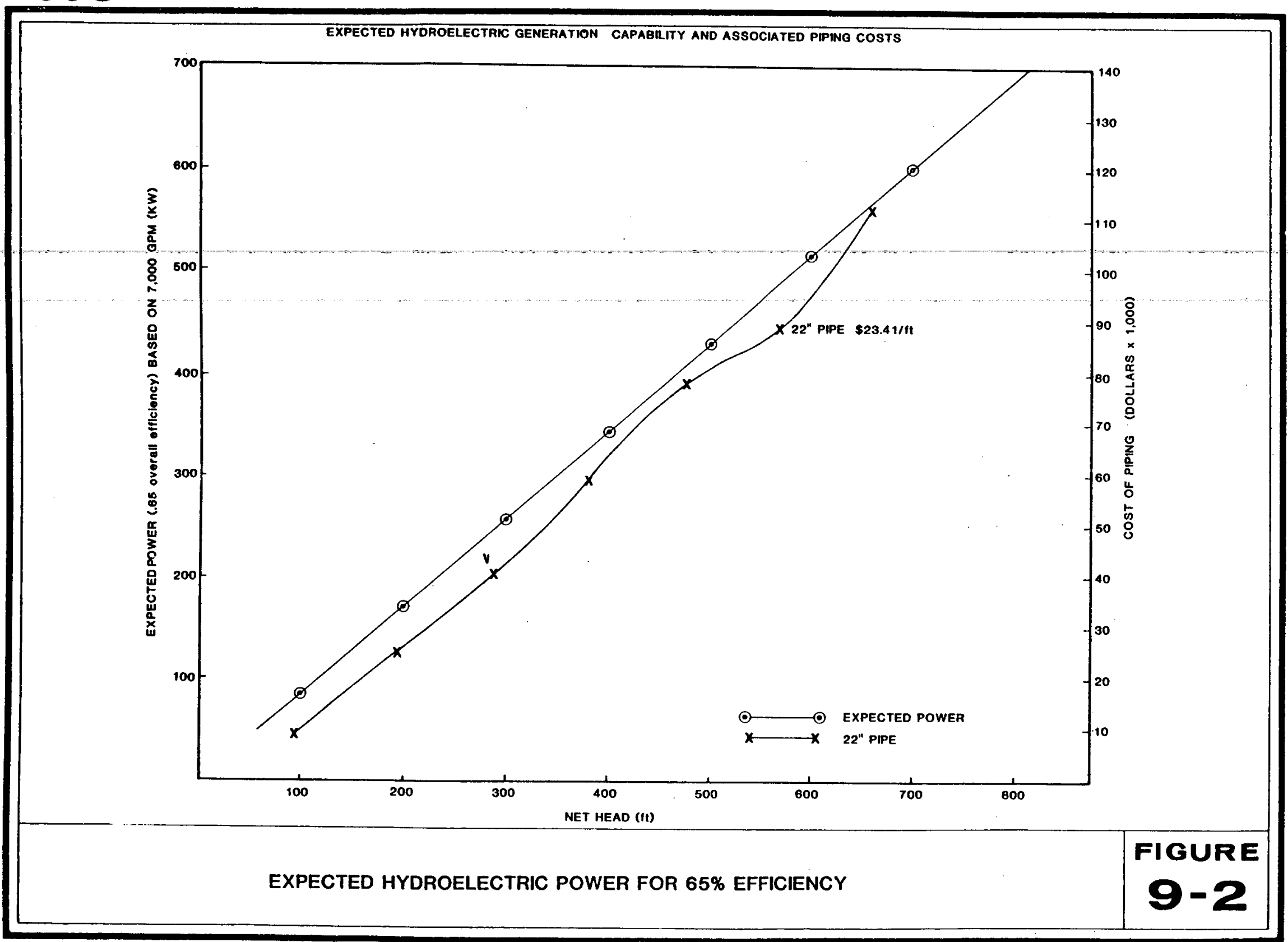


c. Chromium

The concentrate is sintered with soda ash to form sodium chromate which is leached out with hot water and then evaporated to a concentrated solution. This solution is then oxidized to dichromate with sulfuric acid and separated from $\mathrm{Na}_{2} \mathrm{SO}_{4}$ by fractional crystallization.

d. Lead-Zinc Sulfide Concentrates

The closing of lead smelters due to non-compliance with air quality standards have resulted in investigation for processes that are simple, economically competitive, non-polluting and low in capital cost. One such process is advanced by the U.S. Bureau of Mines (Kirby and Barclay, 1975). Lead-zine concentrates are chlorinated in an aqueous slurry to produce lead chloride, lead sulfate and solubilized metal values. After filtration, the residue is treated with hot brine to solubilize lead as the chloride. Cadium, silver and copper are obtained from the leach liquor, which already contains zinc. The purified solution is evaporated to recover zine chloride from which zine and chloride are recovered by fused salt hydrolysis.

e. Molybdenum

Bulk copper-molybdenum concentrate made in copper flotation is thickened with lime and then steamed for two hours to remove the collector film from the copper minerals, filtered, subjected to flotation, which results in a rough molybdenite concentrate.

\section{f. Tungsten}

Processing consists of sulfide and heavy metal flotation, pressure digestion, and solvent extraction. This solution is crystallized to produce a final product (see Section 1.4.2 of this document for further information).

\subsubsection{Mineral Production Close to Geothermal Resources}

A brief survey of mineral processing plants was undertaken to determine their location relative to geothermal resources. A 1979 map prepared for the United States Geological Survey by the National Geophysical and Solar-Terrestrial Data Center National Oceanic and Atmospheric Administration titled "Geothermal Energy in the Western United States" was used to locate identified hydrothermal convection systems. All mineral processing plants below are within an area noted for existing geothermal waters or designated as an area that is favorable to discovery of a local source of geothermal fluid. 
Table 9-1

MINERAL PROCESSING PLANTS CLOSE TO GEOTHERMAL RESOURCES

\begin{tabular}{|c|c|c|}
\hline Company & $\begin{array}{c}\text { Plant } \\
\text { Location }\end{array}$ & Mineral \\
\hline Duval Sulpher \& Potash & Pima, Arizona & Molybdenum \\
\hline Minerals Engineering & $\begin{array}{l}\text { Salt Lake City, } \\
\text { Utah }\end{array}$ & Tungsten \\
\hline Union Carbide & Durango, Colorado & Vanadium \\
\hline Nuclear Corporation & Phoenix, Arizona & Rare Earth, Yttrium \\
\hline Anaconda & Anaconda, Montana & Manganese \\
\hline $\begin{array}{l}\text { Nevada Consolidated } \\
\text { Corporation }\end{array}$ & Hurley, New Mexico & Molybdenum \\
\hline Union Carbide & Mono County, California & Tungsten \\
\hline
\end{tabular}

Further investigation into each mineral processing plant would be required before it could be determined whether or not its energy requirements are adaptable for geothermal energy substitution.

\subsubsection{Conclusion}

The key for utilizing geothermal energy in mineral processing is the location of the processing plants close to a geothermal resource. Hydrometallurgical processing is adaptable to geothermal energy - even when the location of the mine is fixed, the location of the primary production need not be. Weight loss after mining and milling is commonly not great and it is "typically cheaper to ship concentrated source material to a recovery plant than to interrupt an integrated production sequence that continues through the output of primary products to formed or fabricated articles" (Brooks, 1965).

Other methods exist for tungsten extraction. According to the U.S. Bureau of Mines, Searles Lake, California contains an estimated 135 million tons of tungsten; nearly half of all known United States reserves. Extraction of tungsten from this ambient temperature geobrine can be accomplished with a low concentration of tungsten, as little as $70 \mathrm{ppm}$.

The key to the process is a metal selective ion-exchange resin formulated by the U.S. Bureau of Mines (Parkinson, 1978). The resin is polymerized hydroxyguinolineethylenediamine-resorcinol-formaldehyde, referred to as HERF. The tungsten is recovered as an ion-tungsten concentrate which can be sold to refiners. There are three main process steps which recover 95-100 percent of the tungsten in the geobrine; 
tungsten absorption, elution with a weak solution of soda-ash and co-precipitation with ferric chloride. At this time, the recovery technique has not been proven to be economical, but continued research on solvent-extraction techniques may develop an economically feasible process.

Secondary recovery for a variety of minerals may become economic if mineral prices rise. Domestic high grade ores have been used up, and it is certain the demand in the United States will continue to outpace domestic supply. The mining industry is challenged to produce minerals and metals from lower grade resources and possibly reclaim minerals that are currently in waste dumps as the concentration of minerals in the dumps approach that of the ore currently being mined. Current ecological concerns are also beginning to limit traditional mining and processing techniques. Methods for refining raw ore that are more compatible with the environment may lend themselves to the use of geothermal energy. 


\section{REFERENCES}

American Metal Market, Metal Statistics 1975, Fairchild Publications.

Bartlett, R.W., D.D. MacDonald, and E.P. Farley, Sulfide Precipitation of Heavy Metals from High Salinity Geothermal Brine.

Brooks, David B., 1965, Supply and Competition in Minor Metals, Resources for the Future.

California Division of Mines and Geology, 1979, Mines and Mineral Producers Active in California During 1978, Special Publication 53.

Kirby, Ralph C. and James A. Barclay, 1975, Extraction Processes for Low-Grade Ores, U.S. Bureau of Mines.

Parkinson, Gerald, 1978, "New Technology Tries to Tap Tungsten Trove," Chemical Engineering.

Taggart, Arthur F., 1954, Handbook of Mineral Dressing Ores and Industrial Minerals, John Wiley \& Sons, Inc.

Vogely, William A (editor), 1976, Economics of the Mineral Industries, American Institute of Mining, Metallurgical and Petroleum Engineers, Inc. 


\section{APPENDIX A}

The method for calculating heat flux from the office buildings and change rooms is shown below. A detailed calculation for heat losses is shown for the mill change room. Cross sections of a typical wall section is shown in Figure A-1. These heat flux calculations were used in calculating the heating load on the buildings that would replace current space heating with a geothermal energy source. Thermal properties and resistance values of typical building and insulating materials were taken from ASHRAE Handbook and Product Directory (ASHRAE, 1977).

\section{HEAT FLUX CALCULATIONS}

\section{WALLS}

$\begin{array}{ll}\mathrm{U}_{\mathrm{av}} & =\mathrm{S} / 100\left(\mathrm{U}_{\mathrm{S}}\right)+(1-\mathrm{S} / 100) \mathrm{U}_{\mathrm{i}} \\ \mathrm{U}_{\mathrm{av}} & =\text { average } \mathrm{U} \text { value for building section } \\ \mathrm{U}_{\mathrm{i}} & =\mathrm{U} \text { value for area between framing members } \\ \mathrm{U}_{\mathrm{S}} & =\mathrm{U} \text { value for area backed by framing members } \\ \mathrm{S} & =\text { percentage of area backed. }\end{array}$

Using values from Figure A-2

$20 \%$ framing typical for $2^{\prime \prime} \times 4^{\prime \prime}$ studs

$$
\begin{aligned}
& R_{i}=13.53, U_{i}=.074 ; R_{s}=6.91, U_{i}=1.45 \\
& U_{a v}=20 / 100(.145)+(1-20 / 100) .074 \\
& U_{\text {av }}=.0882 \mathrm{Btu} /\left(\mathrm{h} \cdot \mathrm{ft}^{2} \cdot \mathrm{F}\right) .
\end{aligned}
$$

\section{WINDOWS}

Flat glass, exterior, winter conditions

$$
\mathrm{U}=1.10 \mathrm{Btu} /\left(\mathrm{hr}^{\prime} \mathrm{ft}^{2} \cdot \mathrm{F}\right)
$$

\section{DOORS}

Exterior door, winter conditions

\subsection{5 in. thick}

$\mathrm{U} \quad=.28 \mathrm{Btu} /\left(\mathrm{hr} \cdot \mathrm{ft}^{2} \cdot \mathrm{F}\right)$ 


\section{CEILING}

Coefficient for pitched roofs (see Figure A-3)

$R_{i} \quad=2.33, U_{i}=.43 R_{S}=6.71, U_{S}=.149$

$10 \%$ framing typical of 2 in. rafters

$\mathrm{U}_{\mathrm{av}}=10 / 100(.149)+90 / 100(.43)$

$\mathrm{U}_{\mathrm{av}}=.402 \mathrm{Btu} /\left(\mathrm{hr} \cdot \mathrm{ft}^{2} \cdot \mathrm{F}\right)$

\section{FLOORS}

See Figure A-3

$\mathrm{R}_{\mathrm{i}} \quad=13.68 ; \mathrm{U}_{\mathrm{i}}=.073, \mathrm{R}_{\mathrm{s}}=11.74, \mathrm{U}_{\mathrm{s}}=.085$

Typical 10\% framing of 2 in. boards

$\mathrm{U}_{\mathrm{av}}=.1(.085)+.9(.073)$
$\mathrm{U}_{\mathrm{av}}=.0742 \mathrm{Btu} /\left(\mathrm{hr} \cdot \mathrm{ft}^{2} \cdot \mathrm{F}\right)$

TOTAL HEAT TRANSFER COEFFICIENT

$\mathbf{U}_{\mathrm{t}}=\left(\mathrm{U}_{\text {walls }} \mathrm{x}\right.$ wall area $)+\left(\mathrm{U}_{\text {door }} \mathrm{x}\right.$ door area $)+\left(\mathrm{U}_{\text {window }} \mathrm{x}\right.$ window area $)$ $+\left(U_{\text {ceiling }} x\right.$ ceiling area $)+\left(U_{\text {floor }} x\right.$ floor area $)+($ infiltration $)$

\section{MILL CHANGE ROOM}

Volume $=42 \times 32 \times 10.4 \mathrm{ft}=13843 \mathrm{ft}^{3}$

Exterior walls gross

$(42 \mathrm{ft} \times 10.3 \mathrm{ft}) 2=\quad 434$

$(32 \mathrm{ft} \times 10.3 \mathrm{ft}) 2=\underline{331}$

765 sq ft

DOORS

$2(3 \mathrm{ft} \times 7 \mathrm{ft})=42 \mathrm{sq} \mathrm{ft}$

WINDOWS

$5(3 \mathrm{ft} \times 1.5 \mathrm{ft})=22 \mathrm{sq} \mathrm{ft}$ 
EXTERIOR WALLS NET

$765-42-22=701 \mathrm{sq} f t$

CEILING

$(29 \mathrm{ft} \times 32 \mathrm{ft})=1856 \mathrm{ft}^{2}$

FLOOR

$42 \mathrm{ft} \times 32 \mathrm{ft}=1344 \mathrm{ft}^{2}$

$\mathbf{U}_{\text {total }}$

$=\left(701 \mathrm{ft}^{2} \times 0.0882 \mathrm{Btu} / \mathrm{hr}^{2} \mathrm{ft}^{2} \cdot \mathrm{F}\right)+\left(42 \mathrm{ft}^{2} \times 0.28 \mathrm{Btu} / \mathrm{hr}^{2} \cdot \mathrm{ft}^{2} \cdot \mathrm{F}\right)$

$+\left(22 \mathrm{sq} \mathrm{ft} \times 1.10 \mathrm{Btu} / \mathrm{hr} \cdot \mathrm{ft}^{2} \cdot \mathrm{F}\right)+\left(1856 \mathrm{sq} \mathrm{ft} \times 0.42 \mathrm{Btu} / \mathrm{hr} \cdot \mathrm{ft}^{2} \cdot \mathrm{F}\right)$

$+\left(1344 \mathrm{sq} \mathrm{ft} \cdot 0.0742 \mathrm{But} / \mathrm{hr}^{\left.-\mathrm{ft}^{2} \cdot \mathrm{F}\right)}\right.$

$\mathrm{U}_{\text {total }}=977 \mathrm{Btu} / \mathrm{hr} \cdot \mathrm{F}$

Total heat flux = Total heat transfer from building + infiltration losses

$=(977 \mathrm{Btu} / \mathrm{hr} \cdot \mathrm{F}) 60^{\circ} \mathrm{F}+2.16\left(13843 \mathrm{ft}^{3}\right)$

Total heat flux $\quad=8.85 \times 10^{4} \mathrm{Btu} / \mathrm{hr}$ 


\section{NUN ${ }_{\text {WESTEC Services. Inc. }}$}

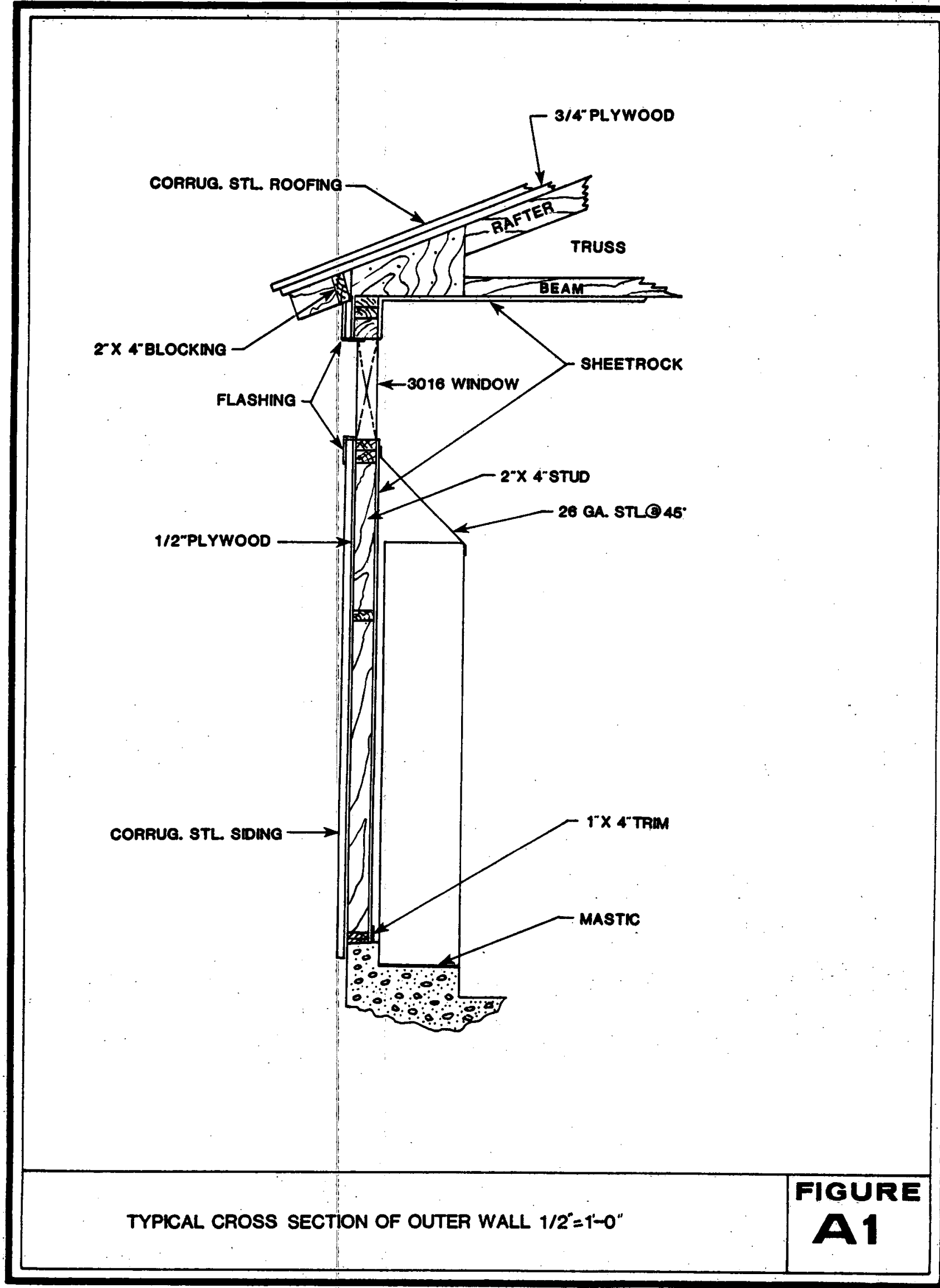

$$
\text { A-4 }
$$




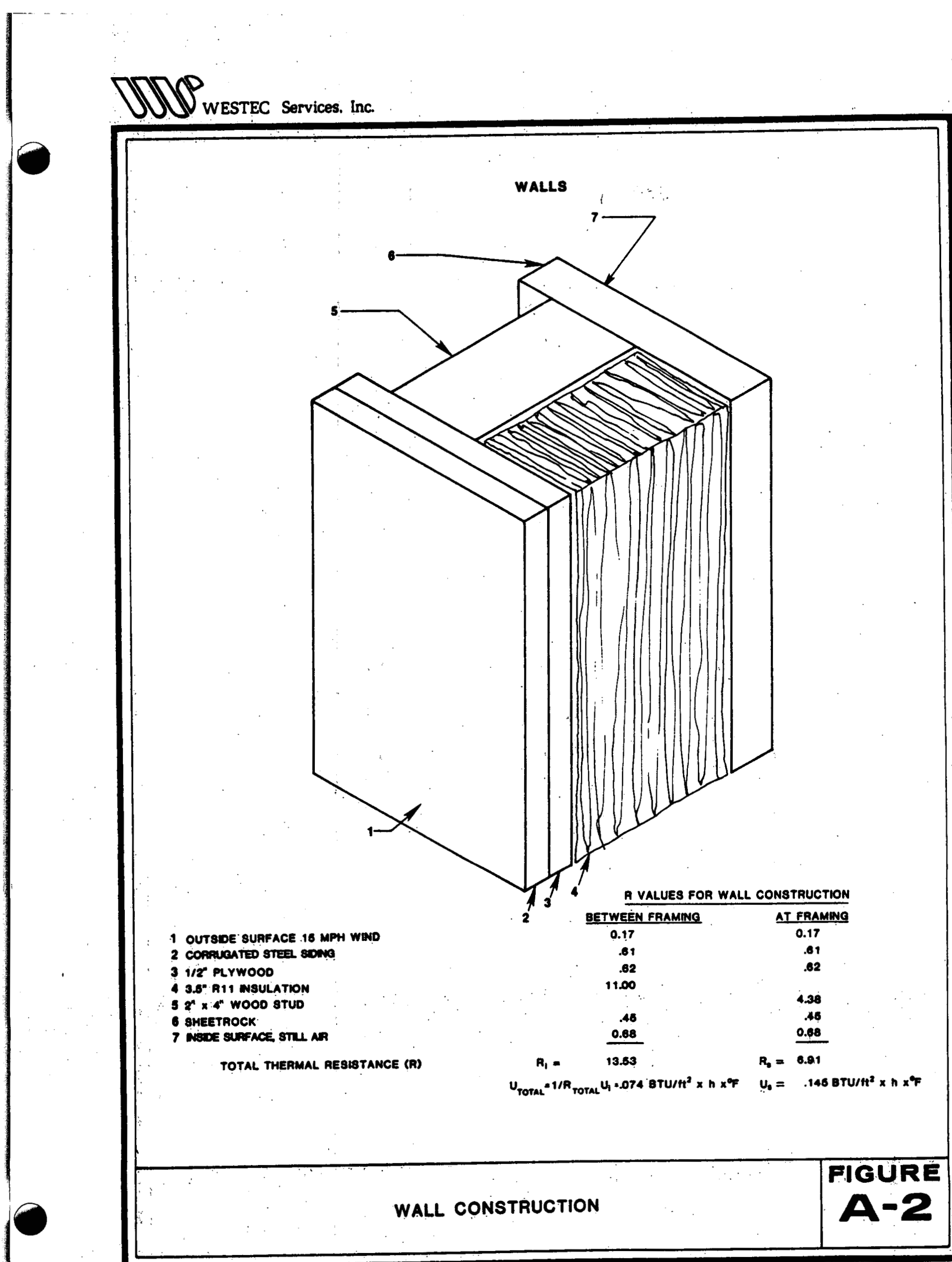




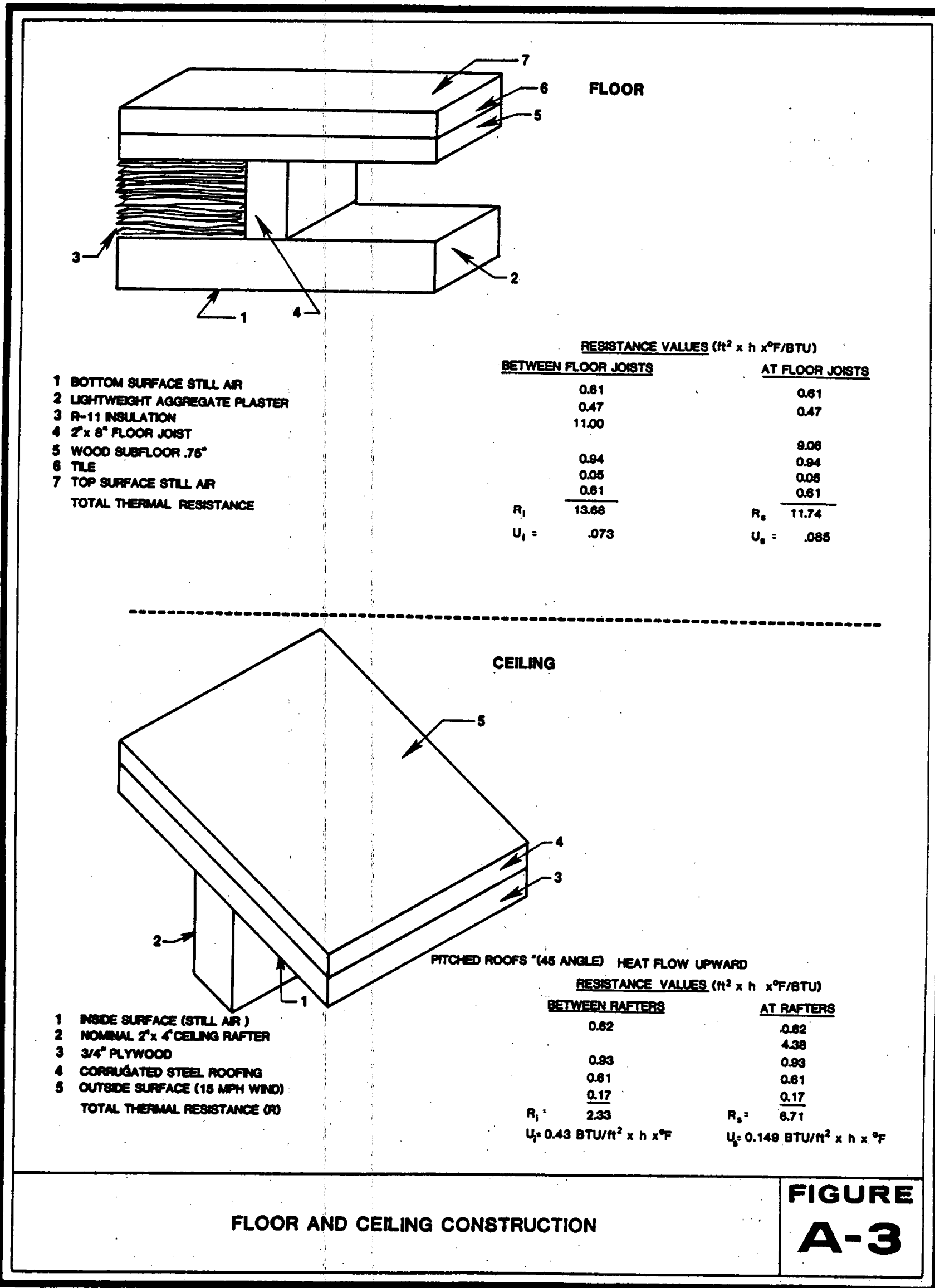




\section{APPENDIX B}

\section{RESERVOIR CONFIRMATION PLAN}

A potential low temperature geothermal resource was identified at the Pine Creek Mine based on observations by Union Carbide personnel of relatively warm water springs inside the mine, by the mine's proximity to the extant Long Valley Known Geothermal Resource Area (KGRA), and by the mine's placement by NOAA (1977) in a potential KGRA. Hydrogeochemical investigations undertaken as part of this study indicate three thermally and chemically distinct groundwaters, which have been used to identify a potential geothermal reservoir with a temperature of up to $100 \mathrm{C}(212 \mathrm{~F})$ as the thermal component to the observed warm spring.

Confirmation of a geothermal reservoir at up to $100 \mathrm{C}$ (212F), capable of providing thermal fluid to produce the observed warm spring, must be approached through data acquisition closer to the anticipated resource. The reservoir confirmation plan includes phased data collection programs that will allow feasibility analysis of proceeding to each sequential phase.

\section{Phase I. Additional Geochemical and Geophysical Investigations}

Task:

Discussion:

Cost Estimate: Geochemistry

Heat Flow and Temperature Gradient

Seismic Monitoring

TOTAL
$\$ 20,000$

$\$ 25,000$

$\$ 15,000$

$\$ 60,000$ 
Task:

Discussion:

Cost Estimate:

Task and Discussion:
Phase II. Exploration Drilling

Drilling a small diameter intermediate depth range hole (600-1000 meters) (1968.6 to $3281 \mathrm{ft}$ ), performing borehole geophysical measurements and monitoring geochemistry of fluids encountered. Borehole geophysics should include induced current and gamma ray logs to indicate lithology, density and neutron logs to indicate porosity, and radioactivity logs. Temperature surveys, fracture frequency and orientation logs should also be conducted.

Slim hole investigations will allow prediction of the depth at which usable temperatures can be achieved. Fluid productivity of rocks in the intermediate depth range will be determined and will allow projection of these parameters to reservoir depths. Initial understanding of the ability of the rocks to receive reinjected fluid can be evaluated. Geochemistry of recovered fluid samples may allow a refinement of reservoir temperature. This phase will reduce the risk of drilling a production diameter and depth drillhole.

Move-on Costs

Drilling $(1000 \mathrm{~m})$

$\$ 12,000$

Expendable Materials (casing, etc.)

$\$ 175,000$

Daita Analysis

$\$ 25,000$

$\$ 12,000$

TOTAL

$\$ 224,000$

\section{Phase III. Drilling and Test Production Well}

1

The production diameter drillhole should be drilled to the depth indicated in Phase II. Well completion should be per appropriate regulations, leaving the production zone chosen during drilling uncased. Perform borehole geophysics as in Phase II and run short duration production tests to determine feasibility of continuing project. Determine bottom hole temperature and make estimations of fluid productivity. If appropriate, proceed to next phase. 
Cost Estimate: Contractor Drilling and Supervisor

Rig-up and Tear-out

Drilling Fluids

Non-salvable

Transportation

Contract Services

(directional tools, surveys,

etc., arill pipe, bits, etc.

other subsurface services)

Conductor Casing 100' - 10"

Surface Casing $1000^{\prime}-133 / 8^{\prime \prime}$

Production Casing 7000'-8 5/8

Tubing 1000' $-27 / 8$

Well Head

Master Valve

Well Pump and Motor

Cementing

Wing Valves

$\begin{array}{lr}\$ & 504,000 \\ \$ & 200,000 \\ \$ & 25,000 \\ \$ & 12,000 \\ \$ & 22,000 \\ \$ & 82,500\end{array}$

TOTAL

\begin{tabular}{rr}
$\$$ & 7,500 \\
$\$$ & 37,500 \\
$\$$ & 172,500 \\
$\$$ & 30,000 \\
$\$$ & 15,000 \\
$\$$ & 7,000 \\
$\$$ & 45,000 \\
$\$$ & 20,000 \\
$\$$ & 7,000 \\
\hline
\end{tabular}

$\$ 1,180,250$

Phase IV. Drill Reinjection Well and Test

Production Well

Task and

Discussion:

Drill reinjection well to the depth and design selected from an evaluation of the Phase III drilling and preliminary testing results. Design and implement a long-term well test of the production well, including both geophysical (temperature and pressure) monitoring and geochemical testing. If indicated from well testing, proceed with the project.

Cost Estimate: Drilling and etc.

$\$ 590,000$

Phase III $\times .5$

$\$ 300,000$

TOTAL

$\$ 890,000$ 


\section{APPENDIX C}

\section{PINE CREEK DISTRIBUTION PIPELINE}

All prices listed below for material and labor are based on 100 foot lengths* of distribution pipeline. The completed pipeline will be laid in an open trench with 2 inches of calcium silicate insulation.

1. A-53 carbon steel pipe 12 inches nominal diameter, standard weight (.375" wall thickness) in 20 -foot lengths, material and labor.

2. Additional labor costs due to accessibility, add 100 percent to normal man-hours.

3. Field-fabricated butt welds in accordance with codes for pressure piping B31.1, 31.2, 31.3, \$171.50 each; 7 for per 100-foot length including welding of flanges. $\$ 1,200.50$

4. Pipe covering protection saddle (2-inch thick covering) $\$ 1,354$ each; 2 per 100 -foot length.

5. Calcium silicate insulation 2-inches thick with aluminum waterproof jacket $\$ 25.50$ per lineal foot of pipe.

6. Expansion joints for temperatures to $400 \mathrm{~F}$ $\$ 579.00$ each; 2 per 100 -foot lengths.

7. Raised face stud bolt and gasket set $\$ 179.49$ each; 4 each per 100 -foot length.

8. Structural excavation for pipeline trench

A. Estimate Quantity of structural excavation via Richardson's Rapid Estimating Handbook (2-12, pg. 1)

\footnotetext{
* All prices taken from Richardson's Process Plant Construction Estimating Standards, copywright 1979.
} 
B. $1000^{\prime}$ of trench $2^{\prime}-0^{\prime \prime}$ wide by 5'-0" deep

i) excavation per foot of length per foot of width $=.1852$

ii) excavation for angles of repose (both sides) per foot of length; class 3 material $=.4630$

C. $2^{\prime}-0^{\prime \prime} \times(.1852)+.4630=.8334 \times 1000=833.4$ cubic yards

D. Trench excavation (2-17, p. 1-5)

Output cubic yards per hour $=\mathbf{1 1 0 . 7}$

i) 833.4 cu. yds $\div 110.7 \mathrm{cu} . \mathrm{yds} / \mathrm{hr}=7.53 \mathrm{hrs}$.

ii) $\quad 7.53$ hrs. @ $\$ 90.73$ per hour $=$

$\$ \quad 683.20$

iii) $8.00 \mathrm{hrs}-7.53 \mathrm{hrs}=.47 \mathrm{hrs}$ $\$ 90.73-\$ 32.00=\$ 58.73$

$\$ 58.73(.47 \mathrm{hrs})=$

$\$ 27.60$

iv) Equipment to site

1 loa'd $\times 2$ hours $\times \$ 55.00$

$\$ \quad 110.00$

v) Total Cost:

Profit (@. 10\%)

$\$ 820.00$

$\$ \quad 82.00$

E. TOTAL SUBCONTRACT:

$\$ \quad 902.00$

AVERAGE for 100'

$\$ \quad 90.20$

9. TOTAL:

$\$ 11,012.77$

10. Distribution Pipeline Costs:

(34 miles) $\$ 11,012.77 / 100$ Ft. $\times 52.8100 \mathrm{Ft} . / \mathrm{mile}=\$ 1.97 \times 10^{7}$ 